
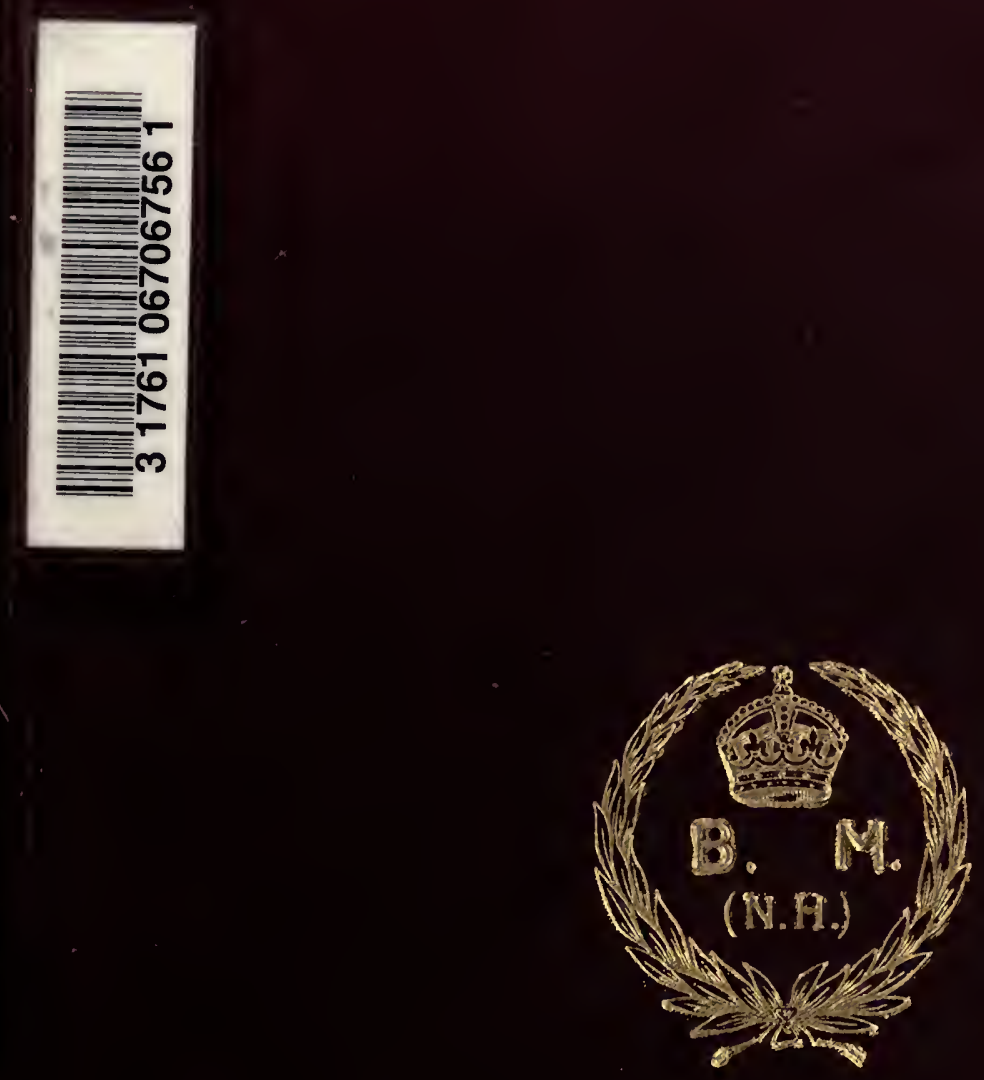


\section{British) Ilzuseum (I2atural bistory).}

This is No..22 of 25 copies of the

"Illustrations of African Blood-Sucking

Flies," printed on special paper.

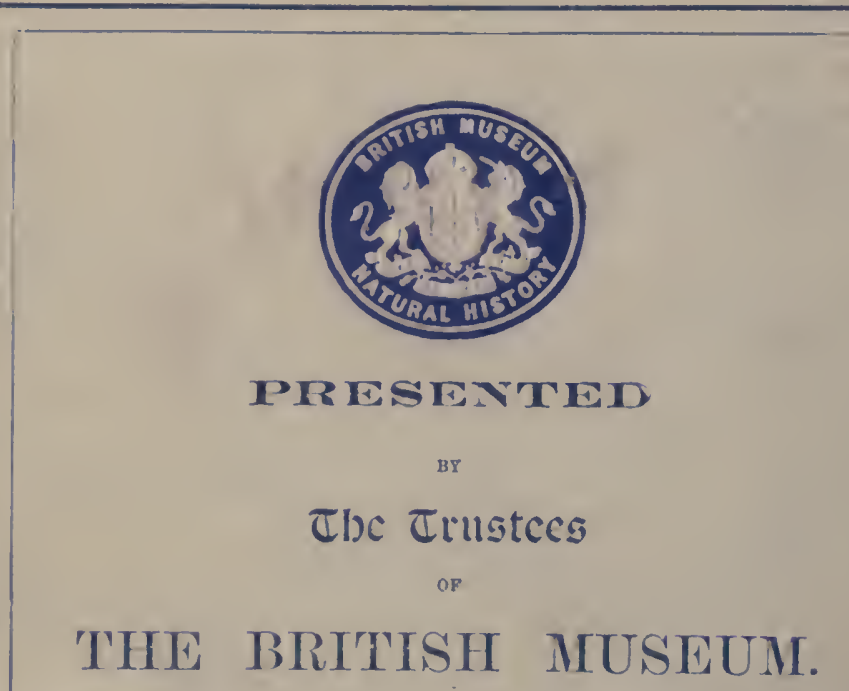






\section{ILLUSTRATIONS OF}

\section{AFRICAN}

\section{BLOOD-SUCKING FLIES}

OTHER THAN MOSQUITOES

AND TSETSE-FLIES

BY

\section{ERNEST EDWARD AUSTEN,}

ASSISTANT IN THE DEPARTMENT OF ZOOLOGY,

BRITISH MUSEUM (NATURAL HISTORY),

WITH COLOURED FIGURES BY GRACE EDWARDS.

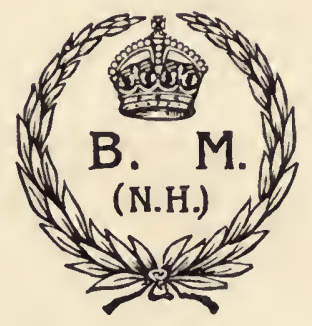

\section{LONDON :}

PRINTED BY ORDER OF THE TRUSTEES OF THE BRITISH MUSEUM.

SOLD BY

Longmans \& Co., 39, Paternoster Row, E.C.;

B. Quaritch, 11, Grafton Street, NeW Bond Street, W.; Dulau \& Co., 37, Soho Square, W.;

AND AT THE

British Museum (Natoral History), Cromwell Road, S.W. 1909.

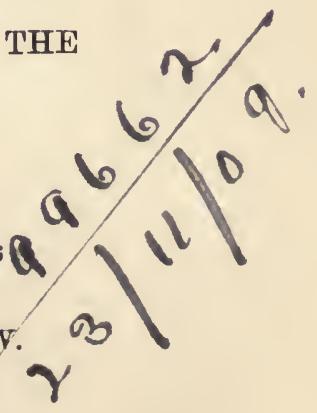

All rights reserved. 
Digitized by the Internet Archive in 2007 with funding from Microsoft Corporation 


\section{PREFACE.}

THE belief that Insects act as the carriers of certain diseases has only of late years been scientifically established. There is, however, at the present time no disposition to underrate the practical importance of an accurate knowledge of the blood-sucking forms. It is hoped that the "Illustrations" now published may be of service to some of those who are engaged in the conflict with disease in Africa, as well as to others who are interested in the study of the Diptera.

A scheme for the preparation of a Monograph dealing with bloodsucking Insects in general was made by Sir E. Ray Lankester, K.C.B., when Director of the Natural History Departments of the British Museum. To wait until the Monograph could have been completed would have been to delay unduly the publication of the information which can now be given. The Diptera, or Two-winged Flies, are not only wanting in the attractiveness of form and colour so noticeable in the Lepidoptera for instance, but they are even regarded with dislike by the majority of people These considerations will account for some of the deficiencies in the collections contained in our Museums ; and the preparation of a satisfactory Monograph must accordingly be preceded by the accumulation of a large amount of material for study.

The Trustees therefore decided, on the suggestion of Mr. Charles O. Waterhouse, Assistant Keeper in charge of the Insect Section, to issue a series of volumes, from time to time, dealing with the blood-sucking Diptera in the way that is found possible and desirable at the moment. Four volumes of a Monograph of Mosquitoes, by Mr. F. V. Theobald, have been issued, from 1901 to 1907; and a fifth volume of the same Monograph is in course of preparation. The Tsetse-flies were described by Mr. E. E. Austen 
iv.

Preface.

in a work issued in 1903. The present volume deals with the Diptera, other than Mosquitoes and Tsetse-flies, which inhabit the parts of Africa indicated in the Author's Introduction. It is hoped that it will be followed in due course by other volumes of the same nature, and that these will collectively form material which will be of service in the compilation of a larger Monograph.

The cordial thanks of the Museum are due to successive Secretaries of State for the Colonies for the encouragement that has been officially given to the Colonial Medical officers to make collections, and to send information to the Museum, as well as to those whose practical efforts in the field have proved so essential to the accomplishment of the present undertaking.

\section{SIDNEY F. HARMER,}

Keeper of Zoology.

British Museum (Natural History),

LoNDON, S.W.

July, 1909. 


\section{INTRODUCTION.}

THE epoch-making discoveries, made within the last fourteen years as to the etiology and mode of dissemination of some of the most formidable diseases threatening human life and progress in the Tropics, have naturally produced widespread interest in the proved or potential living carriers of pathogenic micro-organisms. As regards Blood-sucking Flies, at any rate, nowhere is this interest keener than in Tropical Africa, in the sanitation and development of which the greater number of European nations are more or less concerned. It was therefore thought that "African Blood-sucking Flies (other than Mosquitoes and Tsetse-Flies)" might well be selected as the subject of what is intended to be one of a series of volumes, dealing in a similar manner with the blood-sucking Diptera. In the present work no attempt has been made to provide detailed technical descriptions of species, since experience has shown that such descriptions are of little use to any but specialists. No pains have, however, been spared in order to make the illustrations as accurate as possible, and although it cannot be claimed that they are perfect, it is nevertheless hoped that the standard of accuracy attained in the figures is such as to render detailed descriptions unnecessary.

For the purposes of this book, "African" has been taken as signifying "Ethiopian," except that Egyptian species, owing to their close affinity to or identity with those found in the AngloEgyptian Sudan, have also been included; in other words, with the exception of Egypt, the countries lying to the north of the Tropic of Cancer, and therefore zoo-geographically beyond the northern limit of the Ethiopian Region, have been regarded as outside the scope of the work, so that species found in Tripoli, Tunis, Algeria, and Morocco have been left out of account. The concluding chapter has been devoted to lists of African Blood- 
vi.

sucking Flies arranged under countries. In many cases these lists are obviously of the most fragmentary description, owing to the small amount of material at present available for examination, but it is hoped that this chapter will enable a reader who is interested in a particular Colony or Protectorate to see at a glance what species are known to occur there. The lists will also serve as a basis for future work, and may help to suggest possible disseminators in the event of the outbreak of an epidemic or epizootic which may be thought to be due to Blood-sucking Flies. It must be clearly understood that the omission of the name of any given species from a particular list in no way implies that the species does not occur in the country in question, but simply that up to the present time no specimens of it have been received therefrom by the Museum, or that its occurrence has not been recorded. It may be added that no collections or specimens of Diptera have yet reached the Museum from Dahomey, or from German South-West Africa.

The Blood-Sucking Flies of Africa belong to the same families as those found elsewhere, but certain genera of Tabanidæe (as also the Tsetse-Flies-genus Glossina) are confined to the Ethiopian Region, at least at the present day. Representatives of all these families (with the exception of the Culicidæ, or Mosquitoes) are figured on the thirteen plates at the end of the volume, which provide illustrations of one hundred and two species. The vast majority of blood-sucking flies belong to the Tabanidæ, and although no fewer than eighty-six of the species illustrated in this book are members of this family, those represented are less than one-third of the total number of African species of Tabanidæ already known ; in the case of the remaining families a much larger proportion of the known African blood-sucking species is represented in the plates.

In the first seven chapters, an attempt has been made to supply the fullest possible information as to the bionomics of the families, sub-families, genera, and species mentioned; as will be seen, however, in the case of many of the species the data at present available are limited to a record of localities and dates. The all-important 
subject of the dissemination of disease has been kept prominently in view, and the statements of investigators and observers who have devoted themselves to this question will be found summarised under special headings. In the records of specimens in the possession of the Museum, the names of collectors and donors are printed in italics, in parentheses.

Within the last few years many Colonial Medical Officers in Africa, acting under official encouragement in compliance with instructions from His Majesty's Secretary of State for the Colonies, have made and forwarded to the Museum collections of bloodsucking flies occurring within their districts. Had it not been for the efforts of these and other gentlemen, which have resulted in a welcome increase in the amount of the material in the possession of the Museum, the production of this book would have been wellnigh impossible, and grateful acknowledgment of assistance rendered is accordingly due. While the names of all who have thus assisted cannot here be enumerated, special mention must be made of Colonel Sir David Bruce, C.B., A.M.S., F.R.S.; the late Dr. W. A. Densham, of Uganda; the late Captain Hallam Hardy, R.A.M.C., of the Nyasaland Protectorate; Dr. W. M. Graham, W.A.M.S.; Dr. A. Yale Massey, late of the Tanganyika Concessions, Limited; Dr. J. E. S. Old, of the Nyasaland Protectorate; and Dr. F. Creighton Wellman, late of Benguella, Angola. To the authorities of the Muséum National d'Histoire Naturelle, Paris, the British Museum (Natural History) is indebted for the loan of a number of types in their possession, which has rendered it possible to include figures of several species of Tabanus recently described by Mr. J. R. M. Surcouf. The author desires to express his acknowledgments to Mr. C. O. Waterhouse, Assistant Keeper in charge of the Insect Section, Zoological Department, British Museum (Natural History), with whom it is but just to state that the idea of this book originated.

In conclusion it is perhaps permissible to point out that in the matter of practical investigation by means of experiments on the spot, in order to determine the conveyance or non-conveyance of 
viii.

Introduction.

disease by means of blood-sucking flies other than Mosquitoes and Tsetse-Flies, the British have as yet lagged somewhat behind other nations. Should the present volume have the effect of facilitating such studies, and of drawing attention to the urgent need for work of this kind in our African Colonies and Protectorates, there will be much cause for congratulation.

ERNEST E. AUSTEN.

British Museum (Natural History),

Cromwell Road, London, S.W.

July 12th, 1909. 


\section{CONTENTS.}

$\begin{array}{lrlllllllr} & & & & & & & & \text { PAGE } \\ \text { Preface } & . & \ldots & \ldots & \ldots & \ldots & \ldots & \ldots & \ldots & \text { iii } \\ \text { Introduction } & \ldots & \ldots & \ldots & \ldots & \ldots & \ldots & \ldots & \text { v }\end{array}$

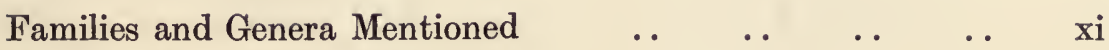

$\begin{array}{lllllllll}\text { List } \text { of Plates } & \ldots & \ldots & \ldots & \ldots & \ldots & \ldots & \ldots & \text { xiii }\end{array}$

$\begin{array}{llllll}\text { Chapter I.—Chironomidæ (Midges) } & \text {. } & \ldots & \ldots & \ldots & 1\end{array}$

$\begin{array}{lllllll}\text { Chapter II.-Psychodidæ } & \ldots & \ldots & \ldots & \ldots & \ldots & 9\end{array}$

$\begin{array}{lllllll}\text { Chapter III.-Simuliidæ . } & \ldots & \ldots & \ldots & \ldots & \ldots & 22\end{array}$

Chapter IV.-Tabanidæ (Horse-flies, Mangrove-flies, Seroots (Seruts) or Seroot-flies, Hippo-flies) $\quad \ldots \quad \ldots \quad 36$

Chapter V.-Tabanidæ (continued). Subfamily Tabaninæ.. $\quad 66$

$\begin{array}{llllllll}\text { Chapter VI.-Muscidæ } & \ldots & \ldots & \ldots & \ldots & \ldots & \ldots & 136\end{array}$

$\begin{array}{lllllll}\text { Chapter VII.-Hippoboscidæ } & \ldots & \ldots & \ldots & \ldots & \ldots & 163\end{array}$

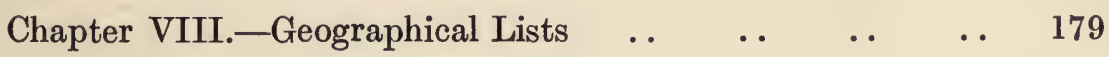

$\begin{array}{llllllllll}\text { Index } & \ldots & \ldots & \ldots & \ldots & \ldots & \ldots & \ldots & \ldots & 213\end{array}$ 

FAMILIES AND GENERA MENTIONED IN THIS BOOK.

\begin{tabular}{|c|c|c|c|}
\hline Chironomidat & .. & . & $\begin{array}{l}\text { Culicoides. } \\
\text { Johannseniella. }\end{array}$ \\
\hline SimULIIDAE . & . & . & Simulium. \\
\hline Psychodid & .. & .. & Phlebotomus. \\
\hline TABAnID & .. & .. & $\begin{array}{l}\text { Chrysops. } \\
\text { Mycteromyia. } \\
\text { Pronopes. } \\
\text { Hinea. } \\
\text { Rhinomyza. } \\
\text { Silvius. } \\
\text { Cadicera. } \\
\text { Pangonia. } \\
\text { Diatomineura (Pangonia). } \\
\text { Subpangonia. } \\
\text { Thriambeutes. } \\
\text { Tabanus. } \\
\text { Thaumastocera. } \\
\text { Holcoceria. } \\
\text { Hæmatopota. } \\
\text { Parhæmatopota. } \\
\text { Hippocentrum. }\end{array}$ \\
\hline MUSCID Æ & .. & .. & $\begin{array}{l}\text { Philæmatomyia. } \\
\text { Stomoxys. } \\
\text { Stygeromyia. } \\
\text { Lyperosia. }\end{array}$ \\
\hline НIPРовоSCID & .. & .. & $\begin{array}{l}\text { Hippobosca. } \\
\text { Echestypus. } \\
\text { Lipoptena. } \\
\text { Pseudolfersia. } \\
\text { Olfersia. } \\
\text { Lynchia. } \\
\text { Ornithomyia. }\end{array}$ \\
\hline
\end{tabular}





\section{LIST OF PLATES.*}

* N.B.-In the case of Tabanus biguttatus, Wied. (Plate VI., Figs. 44, 45), both sexes are represented; in that of Stomoxys omega, Newstead (Plate XIII., Fig. 96), the male alone is shown; all other figures represent the female sex. All the figures are enlarged: the actual wing-expanse (in the case of Figs. 45 and 47 , Plate VI., the actual length) is indicated by a line.

\section{PLATE I.}

1 Culicoides milnei, Austen.

3 Culicoides grahamii, Austen.

5 Simulium latipes, Mg.

7 Simulium wellmanni, Roubaud.
2 Culicoides brucei, Austen.

4 Phlebotomus duboseqi, NeveuLemaire.

6 Simulium damnosum, Theob.

8 Simulium griseicollis, Becker.

\section{PLATE II.}

9 Chrysops funebris, Austen.

11 Chrysops stigmaticalis, Lw.

13 Chrysops dimidiata, v.d. Wulp.

15 Chrysops silacea, Austen.
10 Chrysops longicornis, Macq.

12 Chrysops distinctipennis, Austen.

14 Chrysops bicolor, Cordier (nigriflava, Austen).

16 Chrysops calida, Walk.

\section{PLATE III.}

17 Chrysops brucei, Austen.

19 Cadicera rubramarginata, Macq.

21 Cadicera chrysostigma, Wied.

23 Pangonia sexfasciata, Walk.
18 Rhinomyza denticornis, Wied.

20 Cadicera melanopyga, Wied.

22 Cadicera quinquemaculata, Austen.

24 Pangonia elongata, Ricardo.

PLATE IV.

25 Pangonia zonata, Walk.

27 Pangonia angulata, Fabr.

29 Pangonia gulosa, Wied.

31 Pangonia brunnipennis, Lw.
26 Pangonia adjuncta, Walk.

28 Pangonia compacta, Austen.

30 Pangonia suavis, Lw. 


\section{PLATE V.}

32 Pangonia beckeri, Bezzi.

34 Pangonia rüppellii, Jaenn.

36 Tabanus septempunctatus, Ricardo.

38 Tabanus thoracinus, Pal. de Beauv.
33 Pangonia conjuncta, Walker.

35 Tabanus insignis, Loew.

37 Tabanus obscurissimus, Ricardo.

39 Tabanus par, Walker.

\section{PLATE VI.}

40 Tabanus fasciatus, Fabr.

42 Tabanus africanus, Gray.

44 Tabanus biguttatus, Wied., \&.

46 Tabanus maculatissimus, Macq.
41 Tabanus brucei, Ricardo.

43 Tabanus latipes, Macq.

45 Tabanus biguttatus, Wied., $\nmid$.

47 Tabanus pluto, Walk.

PLATE VII.

48 Tabanus ruficrus, Pal. de Beauv.

50 Tabanus obscurefumatus, Surcouf.

52 Tabanus marmoratus, Surcouf.

54 Tabanus secedens, Walk.
49 Tabanus brumpti, Surcouf.

51 Tabanus quadriguttatus, Ricardo.

53 Tabanus billingtoni, Nowstead.

55) Tabanus kingsleyi, Ricardo.

\section{PLATE VIII.}

56 Tabanus congoiensis, Ricardo.

58 Tabanus fraternus, Macq.

60 Tabanus nigrostriatus, Ricardo.

62 Tabanus conspicuus, Ricardo.
57 Tabanus socialis, Walk.

59 Tabanus variatus, Walk.

61 Tabanus tæniola, Pal, de Beauv.

63 Tabanus liventipes, Surcouf.

\section{PLATE IX.}

64 Tabanus denshamii, Austen.

66 Tabanus nyasæ, Ricardo.

68 Tabanus canus, Karsch.

70 Tabanus subangustus, Ricardo.
65 Tabanus ustus, Walk.

67 Tabanus æneus, Surcouf.

69 Tabanus quadrisignatus, Ricardo.

71 Tabanus albilinea, Walk.

PLATE $\mathrm{X}$.

72 Tabanus diversus, Ricardo.

74 Tabanus wellmanii, Austen.

76 Tabanus gratus, Lw.

78 Tabanus variabilis, $\mathrm{Lw}$.
73 Tabanus sharpei, Austen.

75 Tabanus argenteus, Surcouf.

77 Tabanus laverani, Surcouf.

79 Tabanus rothschildi, Surcouf. 
Plates.

PLATE $\mathrm{XI}$.

80 Tabanus tæniatus, Macq.

82 Tabanus ditæniatus, Macq.

84 Hæmatopota fulva, Austen.

86 Hæmatopota pallidipennis, Austen.
81 Tabanus ruwenzorii, Ricardo.

83 Tabanus claritibialis, Ricardo.

85 Hæmatopota denshamii, Austen.

87 Hæmatopota bullatifrons, Austen.

PLATE XII.

88 Hæmatopota brucei, Austen.

90 Hæmatopota mactans, Austen.

92 Hæmatopota torquens, Austen.

94 Hæmatopota lacessens, Austen.
89 Hæmatopota decora, Walk.

91 Hæmatopota coronata, Austen.

93 Hæmatopota ugandæ, Ricardo.

95 Hippocentrum versicolor, Austen.

\section{PLATE XIII.}

96 Stomoxys omega, Newstead, $ठ$.

98 Hippobosca struthionis, Janson.

100 Hippobosca rufipes, von Olfers.

102 Stomoxys calcitrans, Linn.
97 Stomoxys inornata, Grünberg.

99 Hippobosca maculata, Leach.

101 Stomoxys nigra, Macq.

103 Lyperosia punctigera, Austen. 

CHAPTER I.

\section{Family CHIRONOMID Æ. Midges.}

\section{Subfamily CERATOPOGONINÆE. $6^{3}$ Plate I., Figs. 1-3.}

The Chironomidæ, or true Midges, are slender gnat-like flies of small or sometimes minute size; they are distinguishable from Mosquitoes (Culicidæ), to which the larger and perfectly harmless forms present a strong resemblance and for which they are often mistaken, by, among other characters, the veins of the wings not being clothed with scales, by the absence of the costal vein from the hind margin of the wing, and by the habit of the perfect insects of waving their front legs in the air when at rest. Although bloodsucking Midges are among the most troublesome of all the flies with which this volume is concerned, both on account of the pertinacity of the insects themselves and of the irritating effects of their bites, the blood-sucking habit is exceptional in the family Chironomidæ, and is confined to the females of a relatively small number of species, all of which belong to the subfamily Ceratopogonince. The blood-sucking Midges, which are represented throughout the world, are by far the smallest of all blood-sucking flies, their average length being from $\mathrm{I}$ to $2 \mathrm{~mm}$. They are frequently met with in swarms, and when not flying the wings are invariably carried closed flat one over the other like the blades of a pair of scissors, as in the Tsetse-flies. Little need be said here with reference to structural characters : the antennæ generally consist in both sexes of fourteen joints, six or eight of which in the male usually bear long hair, forming a plume; the palpi are composed of four or five, rarely of three joints; in the wings the second longitudinal vein is wanting, the first and third veins are stouter than the remainder and situate close to the anterior margin, 
and the fourth and fifth veins are forked. The majority of the bloodsucking species belong to the genera Culicoides, Latr. (see below), and Johannseniella, Will. (syn. Ceratolophus, Kieffer, nom. preocc.), in which the blood-sucking habit is apparently universal in the female sex. In addition to these two genera, both of which are widely distributed and fairly numerous in species, a few others, each consisting of one or two blood-sucking species, have been described from Europe and North and South America. The genus Johannseniella differs from Culicoides in the absence of an empodium (median appendage) on the last joint of the tarsi, and in the wings being usually bare; the larvæ are probably aquatic.

Up to the present time only four blood-sucking species of Ceratopogoninæ (Johannseniella imparunguis, Becker, which occurs in Egypt, and the three species of Culicoides figured on Plate I.) have been recorded from Africa,* but this total is probably a mere fraction of the number of species actually existing in the Ethiopian Region. It is much to be wished that collectors of blood-sucking flies would turn their attention to the Midges, but in the case of insects so delicate and fragile, in which the characters available for the distinction of genera and species are necessarily minute, it is impossible to insist too strongly that unless specimens be collected, preserved, and transmitted to England with the utmost care, they will be useless for purposes of determination and description. Tiny flies such as these, if sent home dry without being pinned, cannot subsequently be satisfactorily relaxed for pinning, apart from the fact that they become hopelessly injured by being shaken about loose in a glass tube or chip-box; while to place them in contact with cotton-wool is far worse. As the result of his experience in Ashanti, Dr. W. M. Graham states that Midges are best caught in glass tubes, when settled and sucking on a bare arm, by inverting a tube over the insect, and, when the latter is safely inside, slipping a sheet of paper underneath, thus closing the mouth of the tube.

\footnotetext{
* So far as the faulty condition of the type renders it possible to judge, Ceratopogon castaneus, Walk. (List of the Specimens of Dipterous Insects in the Collection of the British Museum, Part I., p. 26 (1848). - Sierra Leone) belongs to the genus Ceratopogon, Mg., in its restricted sense, and to the sub-genus Forcipomyia, Mg.; it is therefore in all probability not a blood-sucker,
} 
Some of the specimens so collected, after being killed in the ordinary way, should be carefully pinned on dises with No. 20 pins or fine silver wire (with a little practice this will be found by no means so difficult as it may at first sight appear), while others should be preserved in alcohol. Spirit specimens are necessary, since the microscopic characters exhibited by the last joint of the tarsi are often indistinguishable in dried examples.

\section{Genus CULICOIDES, Latreille.}

Genera Crustaceorum et Insectorum, T. IV., p. 251 (1809).

\section{Plate I., Figs. I-3.}

This genus, of which the common European C. pulicaris, L., is the type, consists of small or minute Midges, varying in length from 1 to $2 \mathrm{~mm}$. according to the species, and usually dark greyishbrown or blackish in colour, though the abdomen of the female after feeding is often rosy, owing to the contained blood. The males are distinguishable from the females by their tufted or plumed antennæ and more elongate shape. Although in the figures on Plate I. the short proboscis is shown between the palpi, in reality it is not visible from above, in which position the head itself is usually partly concealed by the thorax. The wings, which, as in all Ceratopogoninæ, when at rest are carried flat, closed one over the other like those of a Tsetse-fly, have their surface, at least in the female sex, more or less clothed with minute hairs, and, though in some species almost devoid of markings, are often conspicuously blotched and speckled with darker colour (Plate I., fig. 2), or else infuscated and marked with hyaline spots (Plate I., figs. 1 and 3). Microscopic characters are provided by the feet, the length of the empodium or median appendage of the last tarsal joint being less than half that of the claws, and the latter having at the base on their under surfaces one or more long and fine setæ, which, in dried specimens at any rate, are often difficult to see. 
Including the three species figured in this book, which are the only ones as yet described from Africa, the number of species at present recognised as belonging to Culicoides amounts to fifty-two, the majority of which are European and North American, though a few have been described from Australia, and one occurs in Brazil. There can be little doubt that many additional African species have still to be discovered.

In spite of their small size, the females of Culicoides are among the most irritating and bloodthirsty of insects, both in the tropics and also in temperate regions. As regards these Midges in Ashanti and on the Gold Coast, Dr. W. M. Graham has kindly supplied the following note:- "Species of Culicoides are known as 'Sand-flies' by Europeans in Ashanti and on the Gold Coast generally. They are most troublesome towards sunset, or between 3.0 and 6.0 p.m.; not very troublesome after sunset, but are often found inside mosquito nets and bite there. Anyone standing quietly near a stream is sure to be bitten by these Midges, which in Ashanti constitute a greater nuisance than any other blood-sucking flies." Writing of a species (perhaps Culicoides grahamii, Austen, Plate I., fig. 3) which is "very common in many places, usually near habitations," in Busoga, Uganda, Dr. Christy says :- "This minute fly can pass through the finest mosquito netting; muslin I have not tried. It bites terribly, leaving an irritating wheal, which itches for days. It makes a sharp short peevish buzz when settling, fully as loud as a Mosquito. It attacks the wrists chiefly, but is able to pass beneath a sheet and bite the ankles and feet. Many were frequently found full of blood on turning down the bed-clothes. I have met with a similar fly, with the same habits, at Ahmednuggar (Bombay Presidency), India."* The "buzz" produced by these Midges when on the wing is also alluded to in the following note by Mr. R. L. Harger, of Blantyre, Nyasaland Protectorate (formerly of the Administration of North-Eastern Rhodesia), written on April 12th, 1907, when sending specimens of a new species with clear

* Quoted by Theobald, under the heading "Ceratopogon, sp.," in Reports of the Sleeping Sickness Commission, No. III., pp. 39-40 (London: Harrison \& Sons. November, 1003). 
hairy wings, which unfortunately arrived in too damaged a condition for description :- "Very small blood-sucking flies, most active early in the morning and in the evening, and in dark huts during the day. A shrill buzz is heard when they are on the wing near one's ear. They will pierce the human skin as quickly as a Tsetse, and like that fly they appear to take their fill and then retire to digest it. The particular specimens sent are from Blantyre District, Shirè Highlands, but I have seen and caught them in North-Eastern Rhodesia, in Tsetse country; they are always found in well-treed country, and sometimes in numbers akin to swarms. They are very active and difficult to catch in a bad light, most readily go for one's ankles and face, and are sometimes quite as annoying as Mosquitoes; the puncture inflicted by them produces a distinct pricking sensation. The abundance of these insects in certain places may render. them quite worthy of the attention of students of blood-sucking flies in relation to disease."

The larvce are very active, eel-like creatures, Life-history. with smooth bodies, consisting of thirteen segments, including the chitinous head; the prothoracic segment is devoid of prolegs on its under side. The tracheal system is entirely closed, and the anal segment bears retractile tracheal gills.* No observations have yet been made on the life-history of any African species of Culicoides, but, like those of other species of the genus, the larvæ of African forms probably live in the sap saturating diseased bark on tree-trunks; some are perhaps aquatic.

The pupa in Culicoides is nearly smooth, but, according to Kieffer, the abdominal segments each bear a transverse ridge armed with minute spines.

* For a fuller account of the larva of Culicoides, see Kieffer, Wytsman's "Genera Insectorum," 42me Fascicule, "Diptera: Fam. Chironomidæ," pp. 53, 54 (Brussels : P. Wytsman, 43, Rue Saint-Alphonse, 1906). 
Culicoides milnei, Austen.

Annals and Magazine of Natural History, Ser. 8, Vol. III., p. 283 (1909).

Plate I., Fig. 1.

The only specimens of this easily recognisable species at present in the Museum are three females (including the type) from Nairobi, East Africa Protectorate, 5000 ft., May 4th, 1906 (Dr. A. D. Milne), and thirteen females from Wakoli's, Busoga, Uganda, May 8th, 1909 (Captain A. E. Hamerton, D.S.O., R.A.M.C.). Culicoides milnei has not been recorded as yet from any other locality. According to Dr. Milne this species is prevalent at Nairobi in the rainy season, when it invades bedrooms at night. Writing on August 21st, 1906, Dr. Milne stated that these Midges abound in the grass on the Athi Plains during the wet weather, but that, so far as he was aware, there was nothing to connect them with any disease of human beings or domestic animals.

Owing to the pattern of its wing-markings, Culicoides milnei cannot be confused with either of the two following species, the only other African representatives of the genus Culicoides yet described.

Culicoides brucei, Austen.

Annals and Magazine of Natural History, Ser. 8, Vol. III., p. 282 (1909).

Plate I., Fig. 2.

The type and four other females of this species, all of which were taken in the vicinity of the Mianga River, Uganda, in July, 1903 (received from Colonel Sir David Bruce, C.B., R.A.M.C., F.R.S.), are the only specimens at present in the National Collection, and the species has not yct been recorded as occurring in any other locality. The fact that Culicoides brucei sucks blood was mentioned 
by Colonel Bruce when forwarding the examples from the Mianga River, but nothing more can yet be said with regard to its habits. The pattern and diffuse character of the wing-markings will serve to distinguish $C$. brucei without difficulty from either the foregoing or following species.

\section{Culicoides grahamii, Austen.}

Annals and Magazine of Natural History, Ser. 8, Vol. III., p. 280 (1909).

Plate I., Fig. 3.

This tiny Midge, the length of which, inclusive of the head, is only $1 \mathrm{~mm}$. or scarcely more, is evidently very widely distributed in Tropical Africa, since the thirteen specimens in the Museum are from Ashanti, Southern Nigeria, the Congo Free State, and Uganda. The precise details as to localities, etc., are as follows.-Ashanti : Obuasi, November 17th, 1907, type and three other specimens, taken on the arm of a European at 5.0 p.m. (Dr.W.M.Graham, W.A.M.S.). Southern Nigeria : Cross River, 1906 (Dr. R. W. Gray, W.A.M.S.) ; Forcados, Mày, 1908 (G. C. Dudgeon). Congo Free State: Binza, near Leopoldville, December 13th, 1903 (the late Dr. J. E. Dutton, and Drs. J. L. Todd and Cuthbert Christy). Uganda Protectorate : Bwamba Country, Semliki Valley, South-West Uganda, $2700 \mathrm{ft}$., " in forest," 1905 (M. T. Dawe).

Writing of Culicoides grahamii in Ashanti Dr. W. M. Graham says*:- " A very minute species, bloodthirsty, and especially troublesome in the afternoon in verandahs and houses." With reference to this Midge as met with in the Congo Free State by the members of the Expedition of the Liverpool School of Tropical Medicine to the Congo, 1903-05, Dr. C. Christy has supplied the following note:- "This species is the most venomous blood-sucker in the Congo Free State. The irritation caused by its bite is severe,

* "Report by Dr. W. M. Graham upon Entomological Observations made in Southern and Central Ashanti, 1907," page 8 (issued by the Colonial Office, 1909). 
and the wheal raised by it is relatively very large, and still itches on the following day. The members of the Expedition encountered this fly only in small villages, surrounded by vegetation."

When forwarding the specimens from the Bwamba Country, South-West Uganda, recorded above, Mr. M. T. Dawe, of the Scientific and Forestry Department, Entebbe, Uganda, wrote as follows on September 2nd, 1905 :- " The bite of this species is very irritating, even more so I think than that of the "mbwa"-fly, that I sent you from the Mabira Forest. These Midges are more troublesome during dull days, and bite fiercely in the early morning and evening, raising large irritating wheals that itch badly. They sometimes soar in large numbers, from four to six feet above the ground. The Luamba name for the fly is Bukukuni."

Culicoides grahamii would appear to be the African representative of the equally bloodthirsty $C$. varius, Winn., of Europe; the wingmarkings of the two species are identical, but $C$. grahamii can at once be distinguished by its much smaller size, paler antennæ, and much more conspicuous pale bands on the tibiæ: British specimens of C. varius exhibit nothing more than faint indications of pale tibial bands.

* Simulium damnosum, Theob.,-see below p. 28, and Plate I., fig. 6. 
CHAPTER II.

\title{
Family PSYCHODID瓜.
}

\section{Subfamily PHLEBOTOMINAE.}

\author{
Plate I., Fig. 4.
}

The little, densely hairy, moth-like* flies belonging to the subfamily Psychodince (genera Pericoma and Psychoda and their immediate allies), which constitute the major portion of this family, are so far as is at present known perfectly harmless, although it has recently been stated $\dagger$ that it is probable that an Indian species sucks blood at least occasionally. These flies, which are to be met with running about on leaves in damp and shady places, or on the windows and walls of outbuildings, have stout, thick-set bodies, rather broad wings, and legs of ordinary length ; the body, margin of the wings, wing-veins, and legs are densely clothed or fringed with hair, and the wings when at rest slope like a roof over the abdomen. The few blood-sucking species of Psychodidæ, which, though likewise hairy, are distinguished from these harmless forms by certain important differences in structure and appearance, belong to the subfamily Phlebotominoe, and, with perhaps an occasional exception, $\$$ to the genus Phlebotomus, the species of which are known to Englishmen as "Sand-flies."

* Sharp (Cambridge Natural History,-Insects, Part II., p. 470 (1899)) calls the Psychodidæ "Moth-flies," and Leonard Haseman, in his "Monograph of the North American Psychodidae" (Transactions of the American Entomological Society, Vol. XXXIII. (1907), p. 299) writes:- “The Psychodidæe have been very appropriately called 'moth-flies,' from the resemblance which they bear to tiny moths." -The designation "Owl Midges," has recently been proposed for this family by Mr. Theobald.

$\uparrow$ By F. M. Howlett, of the Agricultural Research Institute, Pusa, Bengal, in a paper on "Indian Sand-Flies," read before the Medical Congress held in Bombay in February, 1909.

$\ddagger$ As stated in the author's pamphlet, "Blood-sucking Flies," \&c., Third Edition, p. 6, note (London: British Museum (Natural History), 1907), the Rev. A. E. Eaton has in England observed blood in the abdomen of Sycorax silacea, Hal., a Palæarctic species of Phlebotominæ, "and has made a similar observation in Algeria in the case of an undescribed species of the same genus." 


\section{Genus PHLEBOTOMUS, Rondani.}

Sopra una specie di Insetto Dittero; Memoria prima per servire alla Ditterologia Italiana, p. 12 (Parma: Donati, 1840). [Flebotomus.]

$$
\text { "Sand-flies." }
$$

Plate I., Fig. 4.

In appearance the members of this genus, - of which only half-adozen species, from Southern Europe, Africa, India, and North and Central America have yet been described,-are small yellowish, yellowish-brown, or brownish flies, from 1.3 to $2.5 \mathrm{~mm}$. in length according to the species, and with the body and edges and veins of the wings densely clothed with long hair, that on the hind margin of the wings being especially long. Except in the case of females distended with eggs or with blood, the body is slender, especially in the male, in which the end of the abdomen is armed with hooks and claspers of remarkable size and development, which afford useful characters for the distinction of species. The eyes, which are black and prominent, are composed of relatively large, bead-like facets, and, though concealed by the long hair on the crown of the head and back of the thorax when the insect is viewed from above, are very conspicuous when seen from the side. The antennæ, palpi, and legs are long in both sexes, and there is a welldeveloped, beak-like proboscis, which projects vertically beneath the head.

Since no observations worth mentioning have yet been made on the bionomics of African species of this genus, the following summary is necessarily based on work which has been done elsewhere (in Southern Europe and India), but there can be little doubt that the habits and life-history of these insects are much the same wherever they occur.-In his paper read in February of the present year before the Medical Congress in Bombay, Mr. F. M. Howlett,*

* $C f$. note on previous page.-For a copy of this paper $I$ am indebted to the courtesy of the author. 
writing of species met with in bathrooms in India, after referring to harmless Psychodids belonging to the genera Psychoda and Pericoma, remarks :- "In addition to these one may also find sitting on the walls more especially in rather shaded corners, other small flies resembling them in their general hairiness and inconspicuous greyish colour, but having much longer legs and a totally different restingattitude. While the short-legged harmless Psychodids sit in what is roughly the same position that moths usually assume, these other Psychodid flies, which represent the blood-sucking genus Phlebotomus, stand with the body well raised on the long legs, the head down, the tail slightly depressed, and the wings well separated, their tips pointing outwards and upwards." Like other Psychodidæ, flies of this genus do not readily take wing when disturbed, but they are at the same time not altogether easy to catch. Doerr notes that the European Phlebotomus papatasii, Scop., is "extremely shy and very quick in its movements; when approached, these insects make a jump of 10 to $50 \mathrm{~cm}$., seldom more, to the right or left and settle again. They do not as a rule jump forwards or backwards, and it is rare for a specimen to fly for a short distance."* The species of Phlebotomus are essentially nocturnal in their habits, and at night are attracted by light; Doerr states that in guard-rooms in barracks in Herzegovina he has sometimes seen the petroleum lamps completely covered with dead specimens of Phlebotomus papatasii, Scop., adhering to the greasy surface. $\dagger$ "During the day-time," writes Howlett, " they lie up in cool shady places in houses or elsewhere. They have been found under bricks lying in a pile, in hollow trees, behind shutters, pictures, boxes and almirahs, hanging clothes, and other places such as these. They are often found in bathrooms, and still more often in latrines, where the males have been several times seen sucking the moisture from the dirty soil." When approaching a victim on the wing, for the purpose of feeding, a Phlebotomus flies perfectly silently, thus offering a marked contrast to Mosquitoes and Midges. The

* Cf. "Das Pappatacifieber," by Drs. Doerr, Franz, and Taussig, p. 90 (Leipzig and Vienna: Franz Deuticke, 1909).

$\dagger C f$. Doerr, op. cit., p. 112. 
females, which alone feed on blood, are determined and voracious nocturnal pests. As a rule the insects bite only at night, though according to Grassi* in places where the light is dim the South European $P$. papatasii may also bite by day, and Howlett states that in Bengal in September he has been bitten " in full light at 6.30 a.m." Human beings are generally attacked in bedrooms and dormitories, and it is unusual for Phlebotomus to bite out of doors. The bite is severe; one observer, writing from Sevastopol, in the Crimea, says that it is "very painful, especially to newcomers"; and Mr. G. C. Rehling, when forwarding to the Museum specimens of a Phlebotomus, which is a pest during part of the year at Mohammerah, on the Persian Gulf, wrote that:- "They are the most dreaded insects about these parts, their bite being almost as sharp and painful as the application of a red-hot needle. They find their way through all but the finest meshed mosquito-curtains; muslin curtains effectually keep them out. The bite raises a small rose-coloured eruption, with an inflamed surface round about, and is extremely sore and painful, especially if the hands and feet are the affected parts." Howlett writes :- "The flies not infrequently even crawl under the bed-clothes in their lust for blood, and the bite is to most people extremely irritating. The irritation continues during the whole time that the fly is sucking, this time being about two and a half to three minutes when the operation is allowed to be completed without interruption. The effects vary in different individuals. On myself the bite results in a small reddish pimply swelling which persists for several days, the itching at first felt subsiding after a day or so. Children are especially attacked, and often seem to feel the irritation very much. Cattle, dogs, frogs, and caterpillars have also been observed to be sucked. The flies generally bite most freely in the early part of the night and just before dawn, but have apparently no very definite period, ... There is no doubt that variations in humidity and temperature very greatly influence their biting propensities, and a sudden increase of humidity combined with a rise of temperature can

*Cf. Battista Grassi, "Ricerche sui Flebotomi," Memorie della Societì italiana delle Scienze (detta dei XL.), Serie 3a, T. XIV., p. 370 (1907). 
generally be relied on to stimulate them to a special effort. In the act of biting the tail end is raised so that the line of thorax and abdomen makes an angle of forty-five degrees or so with the horizontal ; the abdomen becomes very much distended with blood and except at the extreme tip assumes a transparent red colour: as digestion proceeds this red colour darkens and after about five hours the abdomen appears black; after sixteen hours half the abdomen has been emptied of its contents, while after thirty-six to forty hours the whole meal has been digested and got rid of. When first gorged with blood the insects fly with difficulty, and prefer to sit quietly digesting : they are then easily seen, and can sometimes be caught in the morning sitting inside the mosquitonet." As to the parts most usually attacked by these flies, it was noticed by Doerr in Herzegovina that Phlebotomus papatasii shows a preference for particular regions of the body, "especially the ankles, upper part of the feet, wrists and forearms, particularly the flexor surfaces ; the bend of the knees, legs, upper arms, and neck are more rarely bitten, and the face, back of the neck, back, and thighs are generally spared, even in the case of men lying naked."* With reference to the effects produced by the bite of Phlebotomus papatasii, Doerr writest:- "The bites of Mosquitoes are more easily endurable than those of 'Pappatacis' [Ph. papatasii], which are so painful that the person bitten immediately awakes. The flies exhibit a preference for certain individuals, who are tormented every night, get no sleep until about 5.0 a.m., show a strong reaction with vesicular swellings, œdema, and lymphangitis, suffer frightfully from itching, and look as though they had prurigo, or a peculiar, papular exanthem." The same author adds that in Herzegovina many of the Austro-Hungarian soldiers, who suffer severely from the attacks of these flies, "prefer sleeping in the open on warm summer nights to passing the night in rooms full of Pappatacis."

At the present time our knowledge of the Life-history. life-history of Phlebotomus is mainly due to the celebrated Italian zoologist Professor Battista * Doerr, Op. cit., p. 113. † p. cit., pp. 161-162. 
Grassi, who was the first to discover the metamorphoses of any species of the genus, and two years ago published the results of his researches in the shape of an admirably illustrated memoir on the external and internal morphology and life-history of the South European Phlebotomus papatasii, Scop.* Within the last few months Grassi's results have been confirmed by the observations of Howlett in India. $\dagger$

According to Theobald, $\ddagger$ Dr. Cuthbert Christy found the larvæ of a species of Phlebotomus, stated by him to be very common in Uganda "in water-closets" (sic), in an "old chattie containing almost black infusion of leaves and grass." Possibly however this was exceptional, and in any case, in the present state of our knowledge, the true breeding-places of African species of Phlebotomus can only be inferred from what is known as to the breeding-habits of species of the genus elsewhere. Even on this head the available information leaves much to be desired. Grassi, who in spite of great exertions was only able to find a very small number of larvæ of $P h$. papatasii, although the species is abundant in Italy, met with the specimens obtained by him only in dirty cellars and dark and damp places containing building materials and rubbish of various kinds. $\mathrm{He}$ thinks that house-drains afford especially favourable breeding-places for this species, and sums up his conclusions by saying that:"The larvæ live in dark and damp places, amid all kinds of rubbish ; they prefer underground situations, such as cellars, and more especially the parts of drains that cannot be reached by anything more than splashes of dirty water."§ Howlett, whose assistant, Mr. P. G. Patel, " succeeded in obtaining two larvæ, one from a small open drain channel, and the other from partially dried mud in a channel leading from a well-reservoir," says that:- "The larvæ [of Indian species] live in damp but not very wet earth, and their

* Cf. Battista Grassi, "Ricorche sui Flebotomi," Memorie della Società italiana delle Scienze (detta dei $X L$.), Ser. 3a, T. XIV., pp. 353-394, Tav. I.-IV. (1907).

$\dagger C$ f. F. M. Howlett, op. cit.

$\ddagger$ Reports of the Sleeping Sickness Commission, No. III., p. 39 (London: Harrison and Sons, 1903).

§ Grassi, loc. cit., p. 385. 
food consists of green algal growths." There are, however, good grounds for thinking that the chief breeding-place of the species of Phlebotomus is not the soil, but the dark and damp inner surface of the lower parts of the walls and woodwork of permanent latrines, privies, and cesspools, above the level of the fluid contents. That these flies are common in latrines is a well-known fact, which has been observed in localities so widely different as Herzegovina, Egypt, Ashanti, and Uganda ; and Doerr, while admitting that the true breeding-place of Phlebotomus papatasii is not yet known, mentions facts tending to show, by a process of exclusion, that in at least one military camp in Herzegovina the latrines can be the only possible breeding-ground in the height of summer, that is at a time when "Pappatacis" are most abundant and the soil everywhere absolutely parched up by the heat of the sun.

It would seem that after being fertilised the female Phlebotomus needs a meal of blood for the development of her eggs, even though the insect may have sucked blood before copulation. According to Grassi, the eggs of $P h$. papatasii are rather more than $0.5 \mathrm{~mm}$. in length, elongate oval in shape, and, when seen under a microscope, light brown in colour, with longitudinal dark streaks connected here and there by cross-lines: each female deposits about forty eggs, which are usually scattered over an area of a few centimetres, and, though some may lie in contact with each other, are not deposited in a heap. The eggs of the Indian species observed by Howlett would appear to be considerably smaller than those of Ph. papatasii. Howlett writes :-_" The eggs are $.10 \mathrm{~mm}$. to .15 mm. in length, oval-cylindrical, very slightly curved, and rounded at both ends. They vary in colour from yellowish to dark brown, being white when new-laid, and subsequently show in some species a pattern of hexagonal reticulations, in others more or less parallel zig-zag lines of darker colour. In number they vary from 30 to 80 , the larger numbers being laid as a rule by the smaller species. Oviposition under natural conditions has not been observed, but in captivity the female moves about dropping here and there single eggs; the eggs when extruded are covered with a slightly sticky film and adhere to the surface on which they fall. When an area 
of one or two square inches has becn thus dotted with single eggs, the rest of the eggs, perhaps half the total number, are deposited in one spot in an irregular mass. The females under observation have always died almost immediately after oviposition and sometimes even before the process was quite completed.... The time for hatching varies according to the temperature, from 4 to 6 days in the hot weather to 14 days at the end of November at Pusa."

The larva of Phlebotomus can easily be recognised owing to the presence of long bristles on two tubercles on the last segment of the body (two bristles in the young or four in the nearly adult or adult larva). In Indian species, according to Howlett, these bristles are "often as long as the head and body together, and held conspicuously raised when the animal is walking." The chitinous head, which is totally devoid of eyes, has welldeveloped mouth-parts, and bears a $\mathrm{Y}$-shaped mark above. The body is cylindrical and composed of twelve segments, which are usually transversely wrinkled; each segment bears a transverse row of stout spinous hairs. A pair of spiracles are situate on the first and another on the penultimate segment of the body, and according to Grassi, in the larva of $P h$. papatasii at any rate, "the segments from the fourth to the tenth inclusive each exhibit on the ventral surface, on the fourth fold, an unpaired protuberance, comparable to the sucker-dise in other Psychodid larvæ, which are otherwise very different from those of Phlebotomus." The adult larvæ of the Indian species observed by Howlett are said to be from 2 to $3 \mathrm{~mm}$. in length; those of $P h$. papatasii, according to Grassi, measure rather less than $5 \mathrm{~mm}$., arc whitish or greyish in colour, sometimes tinged with yellow, and more or less transparent. The larvæ of $P h$. papatasii are stated by Grassi to feed on "organic detritus, provided it be not in a state of active putrefaction, and also sometimes on unicellular algæ"; they are very slow in their movements, and the majority of those found by Grassi were concealed by organic débris, which adhered to the dorsal surface.

As regards the duration of the larval stagc and the mode of pupation, Howlctt writes of Indian spccies :- "The length of the 
larval life, as of the egg-stages, varies with the temperature and time of year. The shortest larval period observed has been 14 days in the rains, the longest 48 days. The change to the pupal condition is foreshadowed by a thickening of the thoracic segments, and by the larva seeking a comparatively dry spot. There the last larval skin is shed, the pupa emerging through a slit in the thoracic region, and by its wriggling movements working the skin down to the tail end, where it remains attached to the earth and holding the pupa in place."

Grassi, who states that the pupce of $P h$. papatasii are found in the same localities as the larvæ, usually " concealed in cracks in the stones and bricks," sums up his description of the pupal stage as follows :- " The pupa is motionless, curved, with a dorsal concavity, yellow, and from 2 to $5 \mathrm{~mm}$. in length; it is very easily recognisable from the fact that the posterior extremity (last three segments) is enveloped in the wrinkled and brownish larval skin, which serves as a means of attachment. In shape the pupa is cylindriform, with the anterior half swollen, the posterior half attenuated, and the hind margins of the tergites produced into prominent ridges. When examined under a lens it appears bare. The respiratory papillæ (tubes) are very small, two anterior and two posterior." Howlett writes:- "The pupa, like the larva, has a very characteristic appearance, ... Its most distinct feature is perhaps the prominent ridges and projections on the dorsal surface of the thorax. The duration of the pupal stage, like the others, varies according to temperature from 8-9 days in the rains to 28 days in December." The same author adds :- "The whole period of the life-history from the laying of the egg to the emergence of the fly from the pupa may thus be said to take about one month in the hot weather and two months or more in the cold weather. Observations have however not yet been carried on throughout the whole of the cold weather and the maximum length of life-history is not yet accurately known."

The bionomics and life-history of Phlebotomus

Phlebotomus have been dealt with at some length, since it as a has recently been discovered that these flies disease-carrier. are of considerable importance as disseminators 
of disease; it is therefore eminently desirable that medical men in Tropical Africa should be familiar with the main facts in the economy of the insects, so far as these are at present known, in order that they may serve as a basis for future work. Until about a year ago there was no definite reason for regarding the species of Phlebotomus with greater interest than the majority of other blood-sucking flies, - that is, as being anything more than potential disease-carriers by direct transmission. Dr. André Pressat, Medical Officer of the Suez Canal Company, stated in 1905 that a species of Phlebotomus (very possibly Ph. papatasii, Scop.), which occurs in Egypt, " appears to play an important part in the propagation of Oriental sore," but no evidence was given in support of the assertion.* Again, certain observations made in India by Captain J. D. E. Holmes, I.M.S., Imperial Bacteriologist, point to the advisability of instituting experiments in order to determine whether Phlebotomus is capable of acting as a transmitter of surra and other forms of trypanosomiasis. $\dagger$ Be this as it may, in 1908 it was conclusively proved by the well-known Austrian Army Surgeon R. Doerr, acting as a member of a commission, of which the other members were Staff-Surgeons Franz and Taussig, also of the Austrian Army, that an endemic, non-fatal, three-day fever prevalent during the hot weather in Herzegovina and Dalmatia, is disseminated by the bites of Phlebotomus papatasii, known locally, as also in Italy, as "Pappataci." This fever, which,

*Cf. André Pressat, "Le Paludisme et Les Moustiques" (Paris : Masson et Cie., 1905), Pl. III., and accompanying explanation. Pressat, who mentions that the insect "passes through the meshes of the finest mosquito-curtains," and that it "flies noiselessly, and its bites produce a persistent itching," says that it is called in Arabic Akhl-ou-Skout. According to Dr. F. M. Sandwith, the correct form of this phrase is Akhl-es-Skout, meaning "silent eater."

$\uparrow$ Writing from the Imperial Bacteriological Laboratory, Muktesar (Naini Tal District), United Provinces, India, on January 23rd, 1908, Captain Holmes said :"Last year an outbreak of surra carried off over one hundred tonga ponies on this road .. We noticed a very interesting point. The ponies were badly bitten at night, and in the morning the hairs on the neck and back were covered with small blood-clots. No Tabanidre or Stomoxys were to be found at this time (evening, night, or very early morning), and the only insect that we could detect on the ponies was what appeared like ' gnats,' which you have informed me are a species of Phlebotomus ... Bullocks and cows are bitten in the same manner at night. Ponies worked side by side with, and also standing by day in the same stable as affected ones, did not get the disease when taken about one or two miles apart, and stabled in non-infected stables at night." 
according to Doerr, every summer fills the military hospitals in South Herzegovina and Dalmatia to overflowing,-attacking and rendering temporarily unfit for duty at least 66 per cent. of the Austrian troops during the first hot weather, besides others, presents in many respect a marked resemblance to dengue and Mediterranean "simple continued fever," although according to Lieutenant-Colonel C. Birt, R.A.M.C., the actual identity of the three diseases is not yet established.* "Pappataci fever," as the disease conveyed by Phlebotomus papatasii is now known, is caused by an ultra-microscopic, "invisible" virus, which circulates in the blood during the first day of the fever, but apparently disappears from the circulation by the end of the second day. It is significant that Doerr's investigations, so far as they have yet been carried, tend to show that a certain interval (about eight days) must elapse before a "Pappataci," which has sucked the blood of a patient suffering from the fever, becomes capable of conveying the infection to a healthy individual. $\dagger$

Owing to the small amount of material yet received by the Museum, it is at present impossible to say how many species of Phlebotomus occur in Africa. The existence of species in Uganda and Egypt has already been mentioned ; in the former case the species is perhaps Phlebotomus duboscqi, Neveu-Lemaire (Plate I., fig. 4), which, as stated below, was described from specimens obtained from the region of Timbuctoo, French Sudan, and has also been found in Ashanti and Southern Nigeria. The possibility that the Egyptian species is the South European Ph. papatasii, Scop., has been alluded to above, but in default of specimens for comparison the question must for the moment remain undecided.

* Cf. Lieutenant-Colonel C. Birt, "Experimental Investigation of 'Simple Continued Fever," Journal of the Royal Army Medical Corps, 1908, pp. 566-569.-The members of the Austrian commission incline to the view that the disease investigated by them is identical with dengue.

$\dagger C f$. "Das Pappatacifieber. Ein Endemisches Drei-Tage-Fieber im Adriatischen Küstengebiete Osterreich-Ungarns." By Drs. R. Doerr, K. Franz, and S. Taussig. 8vo, pp.iv. and 166. With 13 figures in the text, 2 plates, and 1 chart (Leipzig and Vienna: Franz Deuticke, 1909). - Cf. also, "A New Invisible Virus" (British Medical Journal, December 5th, 1908, pp. 1706-1707). 
It may be mentioned that, according to information received from Dr. Edward Halford Ross, Sanitary Officer, Port Said :- " The bloodsucking fly Phlebotomus, which is so common throughout Egypt, is not prevalent at Port Said." A species of Phlebotomus which occurs in the Anglo-Egyptian Sudan is very probably also $P h$. papatasii, but in this case again the material available is insufficient to warrant the expression of a definite opinion; two specimens from Kassala, August, 1899 (Captain H. H. S. Morant), are unfortunately both females; so far as it is possible to judge, they exhibit the characters of $P h$. papatasii, and they are certainly distinct from $P h$. duboscqi. The annoyance frequently caused at Khartoum by the nocturnal attacks of a species of Phlebotomus has been alluded to by Dr. Andrew Balfour.*

Phlebotomus duboscqi, Neveu-Lemaire.

Bulletin de la Société Zoologique de France, Vol. XXXI., p. 65, figs. 1-3 (p. 66) (1906).

Plate I., Fig. 4.

This species, the first of its genus to be described from Africa, was originally met with at Hombori, to the south of Timbuctoo, French Sudan, in May, 1905. According to Dr. W. M. Graham, $P h$. duboscqi was a great nuisance in a neglected European latrine at Bekwai Station, Ashanti, on the Gold Coast Government Railway (148 miles from Sekondi), in July, 1907. Besides one specimen from Bekwai, July 9th, 1907 (Mr. Haines, per Dr. W. M. Graham, W.A.M.S.), the Museum possesses a number of females of $P h$. duboscqi in spirit, from the Cross River, Southern Nigeria, 1906 (Dr. R. W. Gray, W.A.M.S.). The abdomens of most of the latter are distended with what seems to be blood, but in one case the distension is due to a mass of relatively large, dark brown

* Cf. Andrew Balfour, M.D., B.Sc., \&c., "Second Report of the Wellcome Research Laboratories at the Gordon Memorial College, Khartoum," pp. 33-34 (Khartoum : Department of Education, Sudan Government, 1906). 
eggs, which appear to occupy practically the whole of the abdominal cavity.

The present species is distinguished from Phlebotomus papatasii, Scop., which occurs in Southern Europe and perhaps also in the Mediterranean Sub-Region,* by, inter alia, its considerably smaller size, by the darker coloration of the hairy covering of the body and wings, and by the much shorter snout and proboscis. It would seem that $P h$. duboscqi must closely resemble the South European Ph. minutus, Rond., but further material of both sexes is necessary before a definite opinion can be formed as to distinctive characters or possible identity.

* As stated above, specimens apparently belonging to $P h$. papatasii, Scop., have been received from Kassala, in the Anglo-Egyptian Sudan. 


\section{CHAPTER III. \\ Family SIMULIID君.}

Plate I., Figs. 5-8.

This family consists of the single genus Simulium.

Genus SIMULIUM, Latreille.

Histoire Naturelle, Générale et Particulière, des Crustacés et des Insectes, T. III., p. 426 (1802-03).

(Sometimes called "Sand-flies.”)

Plate I., figs. 5-8.

At the present time the genus Simulium, which is represented in all parts of the world, includes some eighty recognised species, of which not more than five or six are known to occur in Africa, though no doubt a certain number of new species have still to be discovered. In appearance these insects are small black or greyish* flies, varying in length in the case of the African species at present described from 1.5 to $2.5 \mathrm{~mm}$., with a conspicuously humped thorax, short, straight antennæ, short, bent, four-jointed palpi, broad, delicate, iridescent wings, and moderately stout legs. The proboscis is short, projects vertically beneath the head, and is not visible from above. In the male the eyes appear to occupy the whole of the head, and meet in the middle line above; in the female they are smaller and separate. The thorax and abdomen are frequently clothed with short, close-lying, greyish or shining silvery or golden hair, which, as on the sides of the dorsum of the abdomen of Simulium wellmanni, Roubaud (Plate I., fig. 7), sometimes forms conspicuous patches. In the case of captured specimens, unless

* In Simulium perflavum, Roubaud, which occurs in Brazil, the body is ochraceous, but such a coloration is highly exceptional. 
great care be taken to protect them from injury, this hair is very frequently more or less rubbed off, with the result that the appearance of the specimens becomes much altered. The species of Simulium are difficult to distinguish one from another, but useful distinctive characters are sometimes afforded by the legs. Within the last three years Mons. E. Roubaud has divided the genus into the two subgenera Pro-Simulium and Eu-Simulium, according as "the second joint of the hind tarsi in both sexes is elongate, linear, and without a basal notch" (Pro-Simulium), or "short, curved, and dorsally notched at the base" (Eu-Simulium). Furthermore, in Pro-Simulium the pupæ are said to have a very large number of respiratory filaments, while the cocoons are incomplete and collected in clusters; in Eu-Simulium, on the other hand, the number of the respiratory filaments in the pupa is usually small, and the cocoons are solitary, and complete.*

'The males of Simulium are incapable of sucking blood; the females however are, by day, voracious blood-suckers, inflicting a very severe bite, which leaves behind it an irritating wheal. Since they often occur in enormous swarms, they are frequently a terrible scourge to human beings and domestic animals. With reference to a species of this genus at Bonginda, Lulanga River, Upper Congo, Congo Free State, the Rev. W. D. Armstrong, of the Congo Balolo Mission, wrote as follows in October, $1907:$ - "Native name $N^{\prime} k u t i$ : known among white people as sand-flies. These are very abundant all over the Lulanga River district; they do not appear at night, and are more numerous in the early morning than at any other time of the day. They fly low, and annoy the natives by biting their feet and ankles, drilling a small hole in the skin through which they draw blood. After the operation the mouth of the hole is seen plugged with a tiny drop of blood; the bites itch very much." Of an undetermined species of Simulium met with at Leopoldville and other localities in the Congo Free State, by the members of the Expedition of the Liverpool School of Tropical Medicine to the

* Cf. E. Roubaud, "Aperçus nouveaux, morphologiques et biologiques, sur les Diptères piqueurs du groupe des Simulies": Comptes Rendus Hebdomadaires des Séances de l'Académie des Sciences, T. CXLIII., pp. 519-521 (1906). 
Congo, 1903-05, Dr. J. L. Todd writes:-_" These flies were caught both near, and far from, water. They sometimes occur in swarms and are often found in houses. They bite freely, are persistent in their attacks, and when crushed emit a peculiar 'bed-bug like' odour."*

The preliminary stages are passed in running Life-history. and usually in swiftly-flowing water, and the eggs are deposited in a compact layer or gelatinous mass on stones or plants close to the water's edge. The duration of the larval stage in African species has not yet been observed, but in those found in temperate climates this stage lasts for about four weeks in summer. In shape the larva is somewhat cylindrical, broadest posteriorly, where it is attached by means of a terminal sucker to a stone, the stem of a water-plant, a dead leaf or other object. The larva is able to shift its position by crawling in a looping fashion, attaching itself by means of a thoracic proleg situated on the ventral side close behind the head, but usually it remains in a more or less erect attitude. The head is strongly chitinised, brown or blackish in colour and almost quadrangular; the body consists of twelve segments, from a narrow cleft on the dorsal surface of the last of which are protruded retractile, branched, tracheal gills. The larva feeds on algæ, diatoms, and parts of phanerogamous plants, which are brought to the mouth by means of the currents set up by two broad, fan-like organs situated upon the head. In colour the larva varies according to the species, and perhaps also to some extent in accordance with its food, from deep shining black to yellow or dark green. When mature, the larva spins a silken cocoon, within which it pupates, and in which the pupa remains motionless, breathing by means of a pair of branched respiratory processes, which project from behind the head. About a week (in temperate climates at least) is occupied by the pupal stage, and then the perfect insect, making its escape through a rent in the back of the thorax, ascends to the surface in a bubble of air,

* Annals of Tropical Medicine and Parasitology, Series T.M., Vol. I., No. I., p. 36 (February 1, 1907). 
and makes its way to some support on which it rests until its tissues are sufficiently hardened to enable it to fly.

Although as yet no species of Simulium is

Simulium and known to be capable of acting as a carrier of any Disease. pathogenic micro-organism,* in certain localities, such as parts of the United States of America, the attacks of these flies have frequently occasioned great losses among domestic animals. In attacking horses and cattle the insects show a great fondness for the inside of the ears, but they also devote themselves to any part of the body where the skin is thin and not well protected by hair ; in the case of human beings they frequently attack the corners of the eyes. In South Africa, according to Mr. C. P. Lounsbury, Government Entomologist, Cape Colony, flies of this genus "do not appear to be known as a stock pest, but one or more species affect poultry to a slight extent." †

\section{Simulium latipes, Meigen.}

Klassification und Beschreibung der europäischen zweiflüglichen Insecten (Diptera), I., p. 96 (Braunschweig: Reichard, 1804) (Atractocera].

\section{Plate I., fig. 5.}

Three specimens (two males and one female) of this species have been received from Estcourt, Natal, where they were taken in September or October, 1896, by Mr. G. A. K. Marshall. The female agrees closely with British examples of $S$. latipes, but in the males the legs are considerably paler, the femora, except the tips of

\footnotetext{
* Roubaud states (Bulletin du Muséum d'Histoire Naturelle, T. XII., p. 522 (Paris : 1906) ) that Dr. Buisson, military surgeon of French colonial troops, suggests that it is highly possible that Simulium buissoni, Roubaud, which is abundant at Nuka-hiva, Marquesas Is., and of which Dr. Buisson collected specimens among lepers, helps to propagate leprosy in the French colony in question. No evidence, however, is given in support of this hypothesis.

$\dagger C f$. "Science in South Africa," p. 372 (Cape Town, Pretoria and Bulawayo: T. Maskew Miller, 1905).
} 
the middle and posterior pairs, and the proximal extremities of the tibiæ, being largely buff.

Simulium latipes has not yet reached the Museum from any other African locality, and the occurrence of this European species in South Africa is very remarkable. Unless the fly has been introduced, owing to larvæ or pupæ having been carried in the water-barrels or tanks of a ship, which is possible although perhaps not very probable, it would seem that the presence of $S$. latipes in Natal must be regarded as an instance of discontinuous distribution.

Simulium damnosum, Theobald.

Reports of the Sleeping Sickness Commission, No. III., p. 40 (London : Harrison \& Sons, 1903.)

Plate I., Fig. 6.

There can be little doubt that M. E. Roubaud is correct in believing that this species, which was described originally from Uganda, is distributed throughout Equatorial Africa.* In addition to the type and a large number of other specimens from Uganda, the Museum has received examples of Simulium damnosum from

* Cf. E. Roubaud, Bulletin du Muséum d'Histoire Naturelle, T. XII., p. 141 (Paris, 1906).-According to Roubaud ("Branchies rectales chez les larves de Simulium damnosum Theob. Adaptation d'une larve de Simulie à la vie dans les ruisseaux de l'Afrique équatoriale" : Comptes Rendus Hebdomadaires des Séances de l'Académie des Sciences, T. CXLIV., pp. 716-717 (April 2nd, 1907)), the wide range of $S$. damnosum and its occurrence in the hottest parts of equatorial Africa are due to the complex character of the retractile tracheal gills of the larva, which, as in other species of Simulium, are protruded from a transverse slit on the dorsal surface of the anal segment. Roubaud regards the tracheal gills of the larva of S. damnosum as an instance of adaptation to aquatic life in tropical climates, and asserts that, in the case of the majority of the species of Simulium found in cold or temperate regions, the larval tracheal gills are of a far simpler typo, so much so that a definite physiological value as a respiratory apparatus can scarcely be attributed to them. It should, however, be pointed out that, according to Johannsen, in the larvæe of North American species of Simulium "the retractile, translucent, respiratory filaments (blood gills)," though "sometimes simple," are " of ten much lobed," as, for instance, in the case of Simulium venustum, Say, a species widely distributed in Canada and the United States, and regarded by Roubaud himself as synonymous with the common European Simulium reptans, L. (Cf. O. A. Johannsen, "Aquatic Nematocerous Diptera" : New York State Museum Bulletin 68, Part 6, pp. 348-349, and Plate 37, fig. 9 (1903)). For an account of the tracheal or rectal gills of the larva of $S$. damnosum, the reader is referred to Roubaud's paper. 
the Congo Free State, Southern Nigeria, and the Anglo-Egyptian Sudan, while the species is recorded by Roubaud from French Congo and French Guinea. The details as regards localities, etc., of the specimens in the National Collection are as follows.Uganda: Busoga, near Jinja, 1902 (type and one other specimen.Dr. Cuthbert Christy); precise locality uncertain, November, 1904 (M. T. Dawe). Congo Free State: village near Leopoldville, December 13th, 1903 (Drs. Dutton, Todd, and Christy). Southern Nigeria: Cross River, 1906 (Dr. R. W. Gray, W.A.M.S.). AngloEgyptian Sudan: Abu Hamed, 1905 (Colonel Talbot, per Dr. Andrew Balfour), and March, 1908 (H.H. King).*

With reference to Simulium damnosum in Uganda Dr. Christy writes as follows:- "In travelling through Busoga westward, one passes abruptly, 3 or 4 miles from Jinja, on the Nile, into a 'belt ' of this terrible pest, locally known as the 'Jinja fly.' This belt extends, I believe, from the shores of the Victoria Nyanza about Lubwa's in Busoga, northwards, along the right bank of the Nile, for 12 or 15 miles or more, and is perhaps 3 or 4 miles wide. In this area the flies swarm at certain seasons in millions, and are such a plague that, according to Dr. Hodges, the Medical Officer for Busoga, the natives have to leave their shambas (plantations). I do not remember to have seen the fly on the left bank of the Nile, and I cannot recollect to have met with it in any other part of the Protectorate. There is a patch of particularly dense forest within the 'Jinja fly' belt, where the flies are particularly numerous, . . . The bite of this small fly is a very severe one, and causes a wheal which itches intolerably, and is marked by a large drop of blood. If many flies are allowed to bite and gorge themselves the part streams with blood from the oozing of the punctures. On nearing the sphere of influence of the 'Jinja fly' each porter stops and breaks off a leafy branch to use as a fly swish; the whole of them then collect into a bunch, and travel at increased speed." $\dagger$

* Mr. King has kindly presented to the Museum a number of larvæ and pupæ obtained by him at Abu Hamed.

$\dagger$ Quoted by Theobald, Reports of the Sleeping Sickness Commission, No. III., p. 40 (1903). 
According to Mr. M. T. Dawe, of the Scientific and Forestry Department, Entebbe, the native name of Simulium damnosum in Uganda is mbwa. When sending a tube full of specimens of this species for identification, Mr. Dawe wrote, on November 17th, 1904:- " This small biting fly is known to the natives as mbwa. Its bite is very poisonous and irritable, and causes large swellings, which usually end in sores. Localities where this fly is present are very sparsely inhabited." Mr. Charles White, of Bukalamu, Uganda, writing to the Wellcome Research Laboratories at the Gordon Memorial College, Khartoum, remarks with reference to S. damnosum :- "We have in these parts, near the Ripon Falls, a terrible pest, far worse than mosquitoes-a small black biting fly, which sucks the blood and leaves a painful irritation and sore. Natives have to bind their legs with bark-cloth puttees, and some of their bodies and legs are covered with sores which they tell me are caused by this fly... . These flies are in millions here, and consequently cattle will not thrive."* According to Roubaud, $\dagger$ at Brazzaville, French Congo, where its native name is "Fourou," $S$. damnosum is extremely abundant at certain seasons, and at the time of his arrival was literally in swarms round the legs of natives suffering from sleeping sickness. "The larvæ and pupæ," writes this author, "are to be found in the rapid streams that empty themselves into Stanley Pool. They are attached to aquatic plants, and are generally concealed under the ferruginous deposit adhering thereto." Roubaud was not able to determine the duration of the life-cycle, but is inclined to think that it must be somewhat protracted. At Abu Hamed, in the Anglo-Egyptian Sudan, on the River Nile, according to Dr. Andrew Balfour, $\ddagger$ Simulium damnosum is " at times . . . a veritable terror." Dr. Balfour adds :- "It is known as the 'Kunteb' $\S$ and bites fiercely, though, fortunately,

* Quoted by H. H. King in "Third Report of the Wellcome Research Laboratories at the Gordon Memorial College, Khartoum " (London : Baillière, Tindall \& Cox, 1908 [February, 1909]), p. 209.

$\dagger C f$. E. Roubaud's two papers quoted above.

f "Second Report of the Wellcome Research Laboratories at the Gordon Memorial College, Khartoum" (Khartoum : Department of Education, Sudan Government, 1906), p. 34 .

§ King (loc. cit.) writes this word "Kilteb;"-see below.-E. E. A. 
not during the night. It will follow its unfortunate victim several miles back from the river and renders out-door work impossible."

In March, 1907, the life-history and habits of Simulium damnosum were studied at Abu Hamed by Mr. Harold H. King, Economic Entomologist to the Wellcome Research Laboratories, Gordon Memorial College, Khartoum, who, after describing the bionomics of the Nimitti (S. griseicollis, Becker)," writes as follows $\uparrow:-{ }^{*}$ A second and larger species of sandfly-Simulium damnosum-occurs in the Sudan, in the vicinity of Abu Hamed, where it bears the name of Kilteb.

"The larva (fig. 5) resembles in shape and general appearance the Nimitti larva, but can be distinguished from it by its relatively larger size and darker colour. A dark pigmented patch is usually present on either side of the first thoracic segment.

"Length about $6 \mathrm{~mm}$.

"The pupa (fig. 7) is enclosed in a pocket-shaped cocoon, about $4 \mathrm{~mm}$. in length, similar to that of the Nimitti pupa. The respiratory appendages consist each of a double comb of tubes which do not project much above the edge of the cocoon.

"Life-history and habits.-The life-history of the Kilteb appears to be identical with that of the Nimitti. It has nevertheless been recorded from only one locality in the Sudan-viz., the neighbourhood of Abu Hamed, where its larvæ and pupæ exist in the river in company with those of the Nimitti.

"The adult females are exceedingly vicious blood-suckers, attacking chiefly the ankles and legs. Like the Nimitti, they are most active during the hours of sunset and sunrise.

"The Kilteb do not swarm around the face, trying to crawl into the eyes and ears, but each fly, in a business-like way, settles on the spot it has selected, takes a short preliminary tour, patting the surface with its fore legs, and then, plunging its proboscis into the skin, commences to feed. In from two to three minutes it is fully

* See below, pp. 32-34.

$\dagger$ Loc. cit., pp. 208-209: Mr. King's observations are illustrated (Plate XXIII., figs. $3,5,7$ ) with coloured figures of perfect insect, larva, and pupa. 
gorged, whereupon it flies heavily away, while a tiny trickle of blood flows from the puncture it has made.

"These bites are exceedingly irritating, and in some cases produce considerable swelling.

"Kilteb do not occur at Abu Hamed in very great numbers except during the winter, when the river is low."

Simulium wellmanni, Roubaud.

Bulletin du Muséum d'Histoire Naturelle, T. XII., p. 519 (Paris, 1906.)

Plate I., FIG. 7.

This small black species, with conspicuous patches of silverywhite hair on the sides of the abdominal segments, has hitherto been recorded only from Angola, whence the Museum possesses the type and two other females, taken in the large plain called "BuluBulu," in Bihé, in April, 1905 (Dr. F. Creighton Wellman). The collector's field-note is as follows :- "Native name 'ohomono.' These tiny flies bite viciously, and are dreaded by naked porters. Their bite leaves a large raised wheal, with a_small red spot in the centre, and itches for several days." Elsewhere, in a paper on "Some Angolan Insects of Economic or Pathologic Importance," Dr. Creighton Wellman writes with reference to S. wellmanni:"This tiny fly is possibly one of the most successful destroyers of patience and provokers of profanity in the Colony. Natives near wet plains sometimes are compelled to move their kraals on account of it, and I have had to break camp to escape a swarm. It crawls down one's ncck and up one's sleeves and bites viciously, leaving a tiny red wheal which itches furiously and docs not disappear for some time."*

* Cf. F. Creighton Wellman, Entomological News, Vol. XIX., p. 227 (May, 1908).The species is referred to in error as "Simulium damnosum, Theob." 
Simulium griseicollis, Becker.

Mitteilungen aus dem Zoologischen Museum in Berlin, II. Bd., 3. Heft, p. 78 (1903): Second Report of the Wellcome Research Laboratories at the Gordon Memorial College, Khartoum (Khartoum: Department of Education, Sudan Government, 1906), p. 52 [translation, by E. E. Austen, of original description].

Plate I., Fig. 8.

Described originally from specimens from Assuan, in Upper Egypt, this small yellowish- or greyish-haired, partially pale-legged Simulium is at certain seasons extremely abundant and troublesome in parts of the Dongola Province, in the Anglo-Egyptian Sudan, where it is locally known as Nimitti.* The few specimens at present in the Museum are all from the Dongola Province, and include sixteen examples (unfortunately in a very bad state of preservation) taken in 1905 and forwarded for identification by Dr. Andrew Balfour in 1906, and two females collected in January, 1907 (H. H. King). Mr. King has also kindly presented a number of larvæ and pupæ in spirit.

When forwarding specimens of Simulium griseicollis to Dr. Andrew Balfour in 1905, the Mudir of Berber wrote as follows $†$ :"It occurs in Januàry, February, March and April. It extends from Salamanieh, north of Berya, to the Berti boundary of the Dongola Province on the river. It lives near the river and is not found at a greater distance from it than half a mile. It bites from sunrise to sunset, attacking any part of man or beast unprotected by hair or clothes. Human beings are chiefly bitten on the face and hands, animals in the region of the pudenda. . . . It is most virulent between the extreme cold of the winter and the great heat of the summer. The hot weather kills these flies off in thousands, and

* Dr. Andrew Balfour (Second Report of the Wellcome Research Laboratories at the Gordon Memorial College, Khartoum, p. 34 (Khartoum: Department of Education, Sudan Government, 1906)) writes "Nimetta or Nemetti."

$\uparrow$ Cf. Balfour, loc. cit. 
finally extinguishes them. On very cold days they are not aggressive."

Mr. H. H. King has recently published an interesting account of the habits and life-history of Simulium griseicollis, with coloured illustrations of the different stages, based on observations made by him in the Dongola Province, in December, 1906, and January, 1907.* The larva of S. griseicollis, which is described by Mr. King as "ashy grey to greenish in colour," and about $5 \mathrm{~mm}$. in length when adult, exhibits no specially distinctive external features, but, like the larva of $S$. damnosum, Theob., is apparently provided with well-developed protrusible tracheal gills on the last segment. "The pupa," writes Mr. King, " is pale chestnut brown in colour and is enclosed in a semi-transparent, brown, pocket-shaped cocoon, about $3 \mathrm{~mm}$. in length. Projecting above the edge of the cocoon is a pair of white to greyish white respiratory appendages. Each appendage consists of three leaf-like processes, two of which are united at the base." It may be remarked that the trilobate, leaflike form of the respiratory appendages of the pupa of S. griseicollis is strikingly different from the branching filamentous type, seen in pupæ of European and North American species of Simulium.

Mr. King, after remarking that- "During certain seasons of the year, vast swarms of the little sandfly Simulium griseicollis-locally known as Nimitti-occur in the northern parts of Dongola Province," describes the "Life-history and habits" as follows :-

"The larval stage of the Nimitti is passed in the swiftest running water, the eggs probably being deposited in masses on rocks and plants at the water's edge.

"The larvæ, though aquatic, are poor swimmers, so attach themselves to some fixed support and rely on the current to bring their food to them. They are usually particularly numerous on débris-e.g., sticks and weeds-caught up among rocks. On their support they spin a network of silken threads by means of

* Cf. H. H. King, "Third Report of the Wellcome Research Laboratories at the Gordon Memorial College, Khartoum " (London: Baillière, Tindall \& Cox, 1908 [February, 1909]), pp. 206-208, Plate XXXIII., figs. 1, 2, 4 \& 6.-King's figure of the perfect insect, which has apparently been taken from a denuded specimen, is, unfortunately, misleading as regards the coloration of the body. 
which they are enabled to maintain their position against the strongest current. Frequently they will leave their support and let themselves out into the stream anchored by threads of silk and enabled by them to return.

"When full-fed, they pupate in small pocket-shaped cocoons attached to the support on which the larval stage has been passed.

"The adult emerges in a bubble of air and, having gained the surface, at once takes wing.

"Swarms usually consist almost entirely of females. The males are not blood-suckers and are rarely seen in any numbers far from their breeding-haunts. Sometimes, however, the first swarms of the season are made up largely of males-this was the case in 1906.

"The powers possessed by even the females of actually bloodsucking are very limited, so far as human beings are concerned, as they appear to be unable to pierce the skin except in places such as immediately behind the ear, the forehead, etc. I have never seen them gorged with blood even from these situations. They nevertheless cause intense annoyance both by their habit of crawling into the eyes, ears and nose, and also by continually pricking the skin in their ineffectual efforts to obtain blood.

"They feed mainly on birds and animals.

"On alighting upon a suitable host-e.g., a donkey-the fly creeps down through the hair until it reaches the skin, whereupon it inserts its proboscis and commences to suck blood. In a short time its abdomen becomes enormously distended and the insect then makes its way back out of the hair and attempts to fly. Usually, owing to the quantity of blood it has imbibed, it is unable to proceed more than a few yards before falling to the ground. It then hides itself among the vegetation until the immediate effects of its feast have passed away.

"When walking over a smooth surface, the Nimitti wave their forelegs, apparently using them as feelers. This habit is common to many of the larger Tabanidoe.

"The first swarms usually make their appearance towards the end 
of November and the beginning of December, about the time when the wheat is being sown, but are not present in their largest numbers until the months of February and March. Shortly after this they disappear and are not noticed again until the following winter.

"They are at their worst during the hours of sunset and sunrise, when it is impossible to walk anywhere with comfort without a veil or smoky torch to keep them away. During the heat of the day many of them rest among the vegetation ready to attack anything that approaches their haunts.

"At night they are harmless.

"Their habit of appearing when the wheat is sown, disappearing when the wheat is harvested, and apparently originating among the vegetation, has given rise, among the natives, to the erroneous idea that their presence is entirely due to the wheat.

"Nimitti are not usually a pest in Dongola Province south of Debba, though a stray swarm sometimes reaches Merowe and the -district.

"A glance at the map of Dongola Province will show that at Debba the Nile makes a pronounced bend.

"As the river falls in the autumn, the rocks in the cataracts immediately north of Abu Fatma-the Third Cataract-become exposed. The cataracts then constitute ideal breeding places for these tiny sandflies, which shortly afterwards emerge in myriads.

"During the winter the wind blows steadily from the north and the Nimitti are consequently borne southwards to Debba, and then, owing to the altered course of the river, on into the desert. In the spring the wind changes and blows from the south, carrying away with it most of the Nimitti. As the summer advances, the river rises, the rocks in the cataracts become covered with water, and suitable breeding places are then few and far between.

"The occasional swarms that occur in Merowe and the district are usually to be accounted for by temporary changes in the direction of the wind. Sometimes, however, as in the spring of this year, when the river was exceptionally low, it is possible that rocks 
become exposed in other parts of the river and the swarms that appear there breed locally.

"Nimitti are by no means confined to Dongola Province, though it is usually only there that they occur in very large numbers. Larvæ and pupæ have been taken from the river at $\mathrm{Abu}$ Hamed and at Gebel Umali, while adults are frequently seen during the winter in the vicinity of the river from $\mathrm{Abu}$ Hamed to Khartoum." 


\section{CHAPTER IV.}

\section{Family TABANIDE.}

\section{"Horse-flies"; "Mangrove-flies"; "Seroots" (Seruts) or "Seroot-flies"; " Hippo-flies."}

Plate II., Fig. 9-Plate XII., Fig. 95.

In Africa, as elsewhere, by far the greater number of species of blood-sucking flies belong to this family, which occurs in all parts of the world, includes the largest blood-sucking Diptera, and at present consists of some 1600 described species, though many synonyms are undoubtedly included in this total. The number of species known to occur within the limits of the Ethiopian Region is about 290 , but it is certain that many new species have still to be discovered and described. Most of the species belong to one or other of the four principal genera, Tabanus, Homatopota, Pangonia (sensu latiore), and Chrysops; of these Tabanus is much the richest in species, and in respect of numbers the other genera follow in the order given. The family is divided into the subfamilies Tabaninæ and Pangoniinæ, characterised respectively by the absence or presence of a pair of spurs at the tip of the hind tibiæ.

In appearance the larger Tabanidæ are bulky-bodied flies, though in the genus Hocmatopota the body is generally narrow and elongate, as is also the case in some of the species of Chrysops. As regards size, the African species vary in length from about $5 \mathrm{~mm}$., as in the case of a small specimen of Chrysops inconspicua, Austen (Angola), to about $27 \mathrm{~mm}$., or over 1 inch, as in that of Tabanus grandissimus, Ricardo (North-Eastern Rhodesia and Nyasaland Protectorate); as in Diptera generally, dwarf specimens, due to failure of the foodsupply or other unfavourable conditions during the larval stage, are not uncommon. The head, which is often large, is convex anteriorly, and concave or flattened behind; in the male it is 
almost wholly composed of the eyes, which, with few exceptions, ${ }^{*}$ meet together above in that sex, but in the female are separated by the space known as the front, bearing in Chrysops, Tabanus, and Homatopota a shining spot or callus, the shape and coloration of which afford useful specific characters. The males have an area in the upper portion of the eyes, varying in extent according to the species, composed of larger facets than those below ; this difference is as a rule well-marked in the Tabaninæ, but is often less conspicuous in species of Pangonia or Chrysops. In the living insects the eyes of the majority of Tabanidæ are singularly beautiful, being often golden-green, coppery-green, blue, or brilliantly metallic iridescent, marked with purple or brown bands or spots; these eye-markings are of value for the identification of species, and are especially brilliant in the case of females of Chrysops and Hcomatopota, which, as remarked by Girschner, $\uparrow$ " possess probably the finest eyes of all insects." After death, however, the colour of the eyes rapidly changes to a dull brown or brownish-black, until little or no trace of the markings remains. $\ddagger$

In all Tabanidæ the three-jointed antennæ, which in the genus Chrysops attain a considerable length, project conspicuously in front of the head. In Tabanus and Hcomatopota the proboscis (labium), which contains the piercing mouth-parts, is soft and fleshy, of moderate length, terminated by a pair of large and conspicuous labella, and depends vertically beneath the head. In Chrysops the proboscis, which is still vertical, is more slender and often distinctly elongate; while in Pangonia (sens. lat.) it is strongly chitinised, generally slender, and often horizontal in position and remarkably long, sometimes even considerably exceeding the body in length. The palpi, one of which can be seen on each side of the base of the proboscis, are two-jointed; the terminal joint, which differs in shape in the two sexes, is usually swollen and fleshy in the

\footnotetext{
* In certain species of Chrysops, e.g., Ch. longicornis, Macq., and Ch. fusca, Ricardo, the eyes are narrowly separated above in the male.

$\dagger C f$. E. Girschner, Berliner Entomologische Zeitschrift, Bd. XXXI., p. 156 (1887).

¥ In the figures illustrating this work the eyes are shown as seen in dried specimens, from which the drawings had necessarily to be prepared.
} 
Tabanino, more slender in Chrysops, and relatively small and inconspicuous in Pangonia. The body is clothed with short hair and totally devoid of the large bristles termed macrochætæ. The wings, which in the resting position diverge at the tips or are somewhat tectiform (i.e., sloping like the roof of a house), may be hyaline or nearly so, but are often more or less infuscated, and frequently spotted, blotched, or otherwise marked with dark brown or black; the wing-markings in Hoematopota and in the majority of species of Chrysops are highly characteristic. The legs, which are of moderate length, are as a rule by no means powerfully developed, and often appear comparatively weak, but the tibiæ are sometimes enlarged, and those of the front legs in certain species of Tabanus are remarkably swollen.

With the possible exception of certain species of Pangonia (sens. lat.) in which the proboscis is of exceptional length, the bloodsucking habit is universal in the female sex, though there is reason to believe that when blood is not procurable the females will also feed as the males do, on dew on leaves, the nectar of flowers, " upon the juices of plants, the honey-dew secreted by plant-lice and scale insects, and similar substances."* The females of the majority of species are excessively blood-thirsty during the hot hours of the day, and thrust themselves on the notice of travellers owing to their size and pertinacity, especially in attacking domestic animals,horses, cattle, and camels often streaming with blood in consequence of their attacks ; to human beings the bites are painful, though the effects are not as a rule so lasting as those produced by the bites of Midges and other smaller blood-sucking flies. The species of Hamatopota and the smaller species of Tabanus are remarkable for the quietness with which they alight on their victims, the sharp prick of the bite being often the first intimation of the presence of the fly; the larger species of Tabanus, however, betray their approach by their deep hum. Once the operation of sucking blood is fairly advanced, Tabanidæ, like other blood-sucking Diptera, may easily be captured or killed. Owing to their non-aggressive

*C\%. S. W. Williston, "Manual of North Amorican Diptera." Third Edition, p. 178 (Now Haven: James T. Hathaway, 1908). 
habits, the males of Tabanidæ are comparatively seldom caught, with the result that the majority of Tropical species have been described from the female alone; in the case of Tabanus biguttatus, Wied. (Plate VI., figs. 44, 45), however, males are for some reason encountered much more frequently than usual.*

No observations as to enemies of Tabanidæ appear yet to have been made in Africa, though in other countries these insects are sometimes preyed upon by Robber-flies (Asilidæ), as also by fossorial Wasps belonging to the family Bembecidæ; in the United States of America, as well as in Europe, parasitic Hymenoptera of the genus Phanurus have been bred from egg-masses of species of Tabanus.

Although Tabanus biguttatus, Wied., is the

Life-history. only African species of which the metamorphoses have yet been studied, $\uparrow$ observations made elsewhere upon the life-history of species of Chrysops, Tabanus, and Homatopota show that in their different stages species belonging to these genera closely resemble one another in their various details ; and, in view of the uniformity in structure and habits of the perfect insects of this family throughout the world, it is not likely that the preliminary stages of African species of the genera mentioned are in any way exceptional. The metamorphoses of no species of Pangonia (sens. lat.) have yet been observed.

The spindle-shaped, white, brown, or black eggs of Tabanidæ are deposited closely packed in sub-conical, rounded, or flattened masses, attached to the leaves and stems of plants, or "other smooth surfaces," projecting from or overhanging water, or standing in wet or marshy ground. The larvce are cylindrical and tapering at each extremity, shining and glassy and more or less longitudinally striated, with a small retractile head, and a body consisting of eleven segments. In colour they are whitish, greyish or yellowish, often with darker markings. Of the eight abdominal segments, each of the first seven is encircled near its anterior margin with a ring of fleshy protuberances or false feet, consisting of a transverse 
dorsal ridge, which may exhibit a depression in the median line partially dividing it into two, a rounded tubercle on each side, and four similar ventral ones. The last segment bears a terminal conical retractile prolongation, containing the stigmata or respiratory apertures in a vertical slit, while on the ventral side the anus is situate between a pair of prominent tumid lips. Tabanid larvæ live in water, wet sand or mud, earth or decaying vegetable matter ; they are carnivorous, and prey upon snails, beetle-larvæ, small Crustaceans, worms, etc. The pupa, which is not unlike that of a Lepidopterous insect, and in colour dull yellowish or some shade of brown, remains stationary, and is usually found in earth or damp rubbish at the edge of water. The thorax bears a pair of somewhat ear-shaped spiracular prominences; each abdominal segment is encircled with a ring of slender spines on its distal third, and there are six sharp spines or teeth at the tip of the terminal segment.

So far as present knowledge goes, there is no

Tabanidæ and reason to regard Tabanidæ as regular carriers of Disease. any form of disease among human beings, although it is obvious that these flies, like any other bloodsucking Diptera, may occasionally convey pathogenic organisms, such as Trypanosoma gambiense or Bacillus anthracis.* With respect to domestic animals, however, the matter would seem to rest on a somewhat different footing, for Tabanidæ as a whole may be considered as pests of animals more than of human beings, and the relatively considerable amount of blood that many of these flies are able to imbibe, owing to their large size, obviously increases the risk of their sucking up micro-organisms from infected animals. It will be seen from the statements under the heading "Tabanus and

* Dr. Arthur Pearson, P.M.O., Union Minière du Haut-Katanga, writing from Ruwe, Katanga District, Congo Free State, August 3rd, 1908 (Brit. Med. Journal, October 17th, 1908, p. 1218) on "Sleeping Sickness," says:- "With regard to the possibility that other biting flies, such as Tabanida, may infect, to my mind one may point to the fact that, whereas these are apparently distributed all over the country, and for three months of the year are so plentiful as to be productive of very considerable discomfort even to a clothed European, the disease has confined itself strictly to the riparian population on those rivers where [Glossina] palpalis is found. Surely this evidence is very powerful ... I do not deny, of course, the possibility of infection when one of the Tabanida, interrupted in its feed on an infected native, plunges its still wet proboscis into an uninfected man. But such cases must be very rare, judging from results." 
disease," on pp 70, 71, that in Algeria the brothers Sergent consider that they have proved experimentally that the species of Tabanus which are there most common are able to transmit three forms of animal trypanosomiasis, by biting a healthy animal immediately after having bitten one severely affected, and that in one instance a successful result was obtained with an interval of twenty-two hours between the bites. As regards immediate feeding, the results obtained by the Sergents are supported by those of Rogers in India, and Fraser and Symonds in the Federated Malay States, and it would seem highly desirable that experiments with Tabanidæ and trypanosomiases of animals should be instituted in British Colonies and Protectorates in Africa, in which the necessary conditions are present. The oft-repeated assertions by natives in various parts of Africa as to the responsibility of Tabanidæ for sickness and mortality among their animals are referred to in the following pages, in the notes on Pangonia, Tabanus and Homatopota, and elsewhere ; whether or not they are worthy of credence can only be shown satisfactorily by investigations on the spot.

\section{Subfamily PANGONIINA.}

Plate II., fig. 9-Plate V., Fig. 33.

The genera and species belonging to this subfamily are distinguished from those of the Tabaninæ, as stated above, by the presence of a pair of, often conspicuous, spines or spurs at the tips of the hind tibiæ, on the under side. The majority of the species of Pangoniinæ belong to the genera Chrysops and Pangonia, but the subfamily is far less numerous in species than the Tabaninæ. In addition to the genera Chrysops, Rhinomyza, Cadicera, and Pangonia (including Diatomineura), which are illustrated in this work, the following also occur in Africa :-Mycteromyia (?), * Pronopes, Hinea,

* Except as regards three species described by Bigot, two of which occur at the Cape of Good Hope, while the third is found in India, the genus Mycteromyia, so far as at present known, is confined to South America, and, before it can definitely be regarded as belonging to the African fauna, the types of Bigot's South African and Indian species must be examined in order to see whether their generic position has been correctly determined. 
Thriambeutes, and Silvius. Of these, Pronopes, Hinea, and Thriambeutes are African genera, each of which at present includes but a single species, while seven species of the widely distributed genus Silvius have been described as occurring in the Ethiopian Region. Recently the "subgenus" Subpangonia, Surcouf, has been described* for a new species, the type of which was taken in West Africa, near the frontier between French Congo and Cameroon.

\section{Genus CHRYSOPS, Meigen.}

Nouvelle classification des mouches à deux ailes (Diptera L.), p. 23 (1800) : Illiger's Magazin für Insektenkunde, Bd. II., p. 267 (1803).

Plate II., and Plate III., fig. 17.

Some seventeen species of this widely-distributed and easily recognisable genus are at the present time known to occur in the Ethiopian Region. The African species of Chrysops are of medium size, not. exceeding $10.5 \mathrm{~mm}$. in length, and occasionally considerably smaller. In the majority of cases the wings exhibit a conspicuous black or dark brown band, running obliquely across the surface from the more or less infuscated costal border (Plate II., figs. 9-12, and Plate III., fig. 17); in Chrysops bicolor, Cordier (C. nigriflava, Austen, Plate II., fig. 14) the distal margin of the transverse band is less sharply defined, while in $C$. calida, Walk. (Plate II., fig. 16), the band is wanting; in C. dimidiata, v. d. Wulp, and $C$. silacea, Austen (Plate II., figs. 13 and 14), rather more than the distal half of the wings is infuscated. In the resting position the wings are carried half open, that is with their tips more divergent than in the case of Tabanus. The presence of three ocelli on the crown of the head is characteristic of the genus, and the face and front exhibit shining tubercles or calli ; occasionally the first joint of the long antennæ is conspicuously swollen (Plate II., figs. 14

* Bulletin du Muséum National d'Histoire Naturelle, Année 1908, p. 283 (Paris, 1908). 
and 16). The eyes, which, as implied by the generic name, are golden green in life, are marked with conspicuous purplish spots and streaks, presenting useful specific characters, ${ }^{*}$ unfortunately indistinguishable in dried specimens.

The females of the genus Chrysops attack human beings as well as domestic and other animals; they are often extremely bloodthirsty, and are capable of inflicting a severe bite. With reference to Chrysops dimidiata, v. d. Wulp, and Ch. silacea, Austen, as met with by him in Southern Nigeria, Mr. G. C. Dudgeon, a competent observer, writes as follows $\dagger:-$ "The effects from a bite of $C$. dimidiatus [Chrysops dimidiata, v. d. Wulp] were similar to a honeybee's sting, causing a good deal of pain and inflammation, but from that of the red Chrysops [Ch. silacea, Austen] even more severe, with dropsical-like swelling of the limb and high temperature. My carriers appeared very much afraid of this insect, and hastily dropped their loads when one came near in order to arm themselves with branches to ward off its attack; this they never troubled to do for other biting flies. Both species mentioned are somewhat similar to Syrphidce (Hover-flies) in appearance, and, as they also hover round the person they intend to attack, their flight is not unlike that of these flies."

From the observations of Hart and Hine upon

Life-history. North American species it would appear that the eggs are usually deposited upright in a single layer, "forming an oval or diamond-shaped area," upon the leaves and stems of plants overhanging pools and small lakes. The eggs, which are white when first laid, gradually turn brown or black. The larvoe live in water, mud, or the matted and sodden remains of aquatic vegetation. Both larva and pupa are of the usual Tabanid type. The larva may be distinguished from that of Tabanus by the last joint of the antenna being considerably longer than the preceding one, instead of the same length or much shorter.

*Cf. V. A. E. Daecke's interesting paper, "On the Eye-Coloration of the Genus Chrysops": Entomological News, Vol. XVII., pp. 39-42, Pl. I. (1906).

$\dagger C f$. G. C. Dudgeon, Journal of Tropical Medicine, Vol, IX., p. 327, November 1, 1906). 
Pupation apparently takes place as a rule in mud, moist earth, or damp sand close to the water's edge ; the pupa is distinguishable from that of Tabanus by the antennæ projecting beyond, instead of not reaching the edge of the head, as also by certain differences in the margins of the spiracular prominences and in the length of the abdominal spines.

Chrysops and No observations on this head have yet been Disease. recorded.

Chrysops funebris, Austen.

Annals and Magazine of Natural History, Ser. 7, Vol. XX., p. 507 (1907).

Plate II., Fig. 9.

This extremely dark-coloured species, in which the body is uniformly black, is at present represented in the Museum Collection by only five specimens, all of which are females. Of these, four are from the north-east side of Lake Edward, Uganda Protectorate, 1906 (Dr. A. D. P. Hodges), while the fifth specimen, which is also from Uganda, was taken on the shore of Lake Victoria, in Buddu, in 1903 (Sleeping Sickness Commission of the Royal Society, per Colonel Sir David Bruce, C.B., R.A.M.C., F.R.S.). No information as to the bionomics of the species it at present available.

Chrysops longicornis, Macquart.

Mémoires de la Société royale des Sciences, de l'Agriculture et des Arts de Lille, Année 1838, 2ième partie, p. 160: Diptères Exotiques, T. I., 1, p. 156, Pl. 19, fig. 2 (1838).

Plate II., fig. 10.

Chrysops longicornis, of which C. tarsalis, Walker, and $C$. 
trimaculatus, Bigot, are synonyms, is a West African species, which appears to be fairly common in Sierra Leone and Ashanti. The Museum collection contains : a female from Sierra Leone, before 1842 (Rev. D. F. Morgan); a second female from Sierra Leone, 1893 (Surgeon-Captain W. G. Clements); five females from Freetown, and Regent, near Freetown, Sierra Leone, September 2nd and 13th, 1899 (E. E. Austen); two females from Sierra Leone, August 12th, and October, 1904 (Major F. Smith, D.S.O., R.A.M.C.); three males and four females from Obuasi, Ashanti, June, 1906, and June 20th, September 8th and 21st, October, and November 13th, 1907, and one male and two females from Kumasi, Ashanti, October 22nd and 27th, 1907 (Dr.W.M.Graham, W.A.M.S.); and one female from Bonny, Southern Nigeria, May 23rd, 1900 (Dr. H. E. Annett). A pair of Dr. Graham's specimens from Kumasi were taken in coitû; a male from Obuasi is labelled "caught on flower of composite plant"; two females from Kumasi and Obuasi were captured in bush-paths, one on the under side of a leaf at 2.0 p.m.; and three females from Obuasi were caught on a window in a ward of a disused hospital (September and October, 1907).

With regard to the behaviour of $C$. longicornis in Ashanti, Dr. Graham supplies the following note:- "This species hovers about one in shady bush-paths, and also hides under leaves, when it is difficult to find ; I have never observed it bite anyone."

Chrysops stigmaticalis, Loew.

Öfvers. af Kongl. Vetensk.-Akad. Förhandl., XIV., 1857, p. 338 (1858) : Dipteren-Fauna Südafrika's, p. 29, Taf. I., fig. 18 (1860).

\section{- Plate II., Fig. 11.}

So far as present knowledge goes, this species, originally described from Kaffraria, would appear to be purely South African. The material in the Museum consists of nine females, from the following 
localities :- "Interior of South Africa," before 1843 (the Earl of Derby); Pietermaritzburg, Natal (R.S. Reece, presented by E. Warren); Pretoria. Transvaal (W. L. Distant), and the same locality, "on horse" (Dr. A. Theiler, C.M.G.) ; and Salisbury, Mashonaland, Southern Rhodesia, November, 1899, and March, 1900 (G. A. K. Marshall).

Chrysops distinctipennis, Austen.

Second Report of the Wellcome Research Laboratories at the Gordon Memorial College, Khartoum, p. 53, PI. IV. (1906).

Plate II., fig. 12.

Care is necessary in order not to confuse this species with the foregoing, from which it may be distinguished by the paler coloration of the proximal two-thirds of the costal border of the wings, and the more slender first joint of the antennæ. From a study of the material at present available it is evident that $C$. distinctipennis has a wide distribution in Tropical Africa, since on the western side of the continent it has been found in Gambia, Ashanti, Northern Nigeria, and French Congo, while it also occurs in Abyssinia and Uganda. The species is represented in the National Collection by seventeen females, the localities, etc., of which are as follows :Bantonding, Upper Gambia, March, 1908 (Dr. T. Hood) ; Navarro, Northern Territories, Ashanti, July, 1907 (Dr. C. Le Fanu); Zungeru, Northern Nigeria, July 14th, 1905 (Dr. Dalziel); near Jangabu, above Bussa, R. Niger, N. Nigeria, November 26th, 1906 (Major C. B. Simonds, R.G.A.); Kontagora and Yelwa, Northern Nigeria, November 30th, 1906, and May 26th, 1907 (J. Brand); Busoga, Uganda, 1903 (Colonel Sir David Bruce, C.B., R.A.M.C., F.R.S.) ; Buruli, Uganda, 1903, "in patch of forest on Lukoge River, half-way between Junda and Kisiliza" (S. C. Tomkins); Wadelai, Uganda, November, 1904, "in swamp" (Captain E. D. W. Greig, I.M.S.) ; Albert Lake District, Uganda, 1905 (Dr. G. H. 
Pooley). In addition to the foregoing the author has examined and determined the following specimens of this species, belonging to the Muséum National D'Histoire Naturelle, Paris ; three females from French Congo, Haute-Alima, May, and "between Banana and Boma, on man," November 15th (E. Roubaud), and one female from Lake Marguerite, Abyssinia, alt. 1120 metres, September 9th, 1907 (Dr. Latham). The specimen recorded above as taken near Jangabu, Northern Nigeria, by Major C. B. Simonds, bears the label :- "In swamp, 1.0 p.m., only specimen seen; taken biting native; bite caused much irritation." In Gambia, according to Dr. Hood, C. distinctipennis attacks horses.

Chrysops dimidiata, v.d. Wulp.

Notes from the Leyden Museum, Vol. VII., p. 80 (1885) [Chrysops dimidiatus].

Plate II., Fig. 13.

A common and troublesome West African species, which has a wide range, including Cabinda (Portuguese West Africa, where the type was obtained), French Congo, Southern Nigeria, and Ashanti. The Museum collection comprises:-Five females from Ologbo, Southern Nigeria, May, 1906 (G. C. Dudgeon); one female from Ndogolai, Cross River, Southern Nigeria, 1908 (G. C. Dudgeon); twenty-two females from Akwete, Opobo River, Southern Nigeria, October, 1907 (Captain W.H.Best, W.A.M.S.) ; and six females from Obuasi, Ashanti, June 10th-July 15th, 1907 (Dr. W. M. Graham,W.A.M.S.).

In Ashanti, according to Dr. Graham, Chrysops dimidiata "frequents verandahs and houses, is extremely bloodthirsty, bites readily, and is a great pest." According to Grünberg, * $C$. dimidiata

* Cf. Dr. Karl Grünberg, “Die Blutsangenden Dipteren,”p. 127 (Jena: Gustav. Fischer, 1907). 
is very common in Cameroon. Roubaud states* that in French Congo, where it bites man, and is known by the native names touna, itouna, and yembé, this species is extremely common and very widely distributed : it is absent during the dry season.

Chrysops bicolor, Cordier.

Bulletin de la Société Entomologique de France, Année 1907, p. 139 (1907). Syn. Chrysops nigriflava, Austen, Annals and Magazine of Natural History, Ser. 7, Vol. XX., p. 518 (1907).

\section{Plate II., fig 14.}

This remarkably handsome black and yellow species has hitherto been received only from German East Africa, whence the Museum possesses three females taken at Neguelo, in Usambara (purchased from H. Rolle). Other specimens from the same locality are in the collection of Professor Bezzi, of Turin, and two females (including the type of Chrysops bicolor, Cordier-a name which has priority over $C$. nigriflava, Austen), from Amani, German East Africa, $\uparrow$ taken by Dr. J. Vosseler, in February, 1906, were forwarded to the Colonial Laboratory of the Muséum National d'Histoire Naturelle, Paris, by the Director of the Museum of the Senckenbergische Naturforschende Gesellschaft, of Frankfort-on-the-Main.

Chrysops silacea, Austen.

Annals and Magazine of Natural History, Ser. 7, Vol. XX., p. 509 (1907).

Plate II., Fig. 15.

Chrysops silacea is a brightly coloured West African species,

* Bulletin du Muséum National d' Histoire Naturelle, Année 1908, No. 5 (Paris, 1908).

$\dagger$ Cordier (op. cit., p. 140) makes the misleading statement that Amani is "near Tombouctou." 
which has hitherto been met with in the Congo Free State, and Southern and Northern Nigeria, so that its range overlaps that of Chrysops dimidiata, v.d. Wulp. The Museum collection contains thirty-five females, from the following localities :Congo Free State: Kimwenza, March 28th, 1904; Yakusu, September 15th, 1904; Kimwosa, Leopoldville, 1904; and N'Kussu, Cataract Region, November 25th, 1904 (the late Dr. J. E. Dutton, and Drs. J. L. Todd and C. Christy). Southern Nigeria: Old Calabar, April 16th, 1892 (received from Sir Patrick Manson, K.C.M.G., F.R.S.) ; a second specimen from the same locality (the late Miss Mary H. Kingsley); Ohumbele, August 6th, 1900 (Dr. H. E. Annett); Odut and Uwet, May, 1906 (G. C. Dudgeon) ; Akwete, Opobo River, October, 1907 (Captain W. H. Best, W.A.M.S.) ; Arochuku, Bende, Cross River, June, 1908 (G. C. Dudgeon). Northern Nigeria: Sapele, 1906 (received from Dr. G. F. Darker); and Akwatcha, Bassa Province, July, 1906, and January and February, 1907 (Dr. G. J. Pirie).

In the Congo Free State this species was met with by the members of the expedition of the Liverpool School of Tropical Medicine (1903-5) " both near and at short distances from water," * while in one instance a specimen was caught in the house of a European. In Northern Nigeria Dr. Pirie found it numerous at Akwatcha in the dry season, and at Sapele it is stated by Dr. Darker to be troublesome to human beings. The severity of the bite inflicted by this species has already been referred to. $\dagger$

\section{Chrysops calida, Walker.}

List of the Specimens of Dipterous Insects in the Collection of the British Museum, Part I., p. 205 (1848) [Chrysops calidus].

Plate II., FIg. 16.

At the present time the Museum is urgently in need of additional

* Cf. Newstead, Dutton and Todd, Annals of Tropical Medicine and Parasitology, Series T. M., Vol.I., No.I., February 1, 1907, p. 43, where the species is referred to as "Chrysops dimidiatus, v.d. Wulp."

$\dagger$ See p. 43. 
specimens of this South African species, which is still represented in the National Collection only by the types of the male and female. Although described so long ago as 1848, the species does not appear subsequently to have been met with, or at any rate recorded, by anyone, and since the types are merely labelled "S. Africa," with a number indicating that they formed part of a collection of South African insects "purchased from Argent," it is even uncertain whether they were obtained in Cape Colony or Natal.

The third joint of the antennæ being unfortunately missing in the types of both sexes, it has only been possible to indicate it in the figure. In coloration the two sexes are alike, except that the light stripes on the back of the thorax are less distinctly marked in the male.

Chrysops brucei, Austen.

Annals and Magazine of Natural History, Ser. 7, Vol. XX., p. 513 (1907).

Plate III., FIG. 17.

A thick-set, medium-sized, dusky species, which has hitherto been met with only in Uganda, and of which the Museum possesses seven females, from the following localities:-Kyadondo, 1903 (Colonel Sir David Bruce, C.B., R.A.M.C., F.R.S.); Singo, 1903 (Colonel Sir David Bruce); Busoga, March, 1906 (Dr. A. D. P. Hodges); and the Nile between Wadelai and Nimule, 1906 (the late Dr. W. A. Densham). With reference to the example obtained by him, Dr. Densham wrote :- " Only specimen seen; taken at an opening in the swampy river edge."

Genus RHINOMYZA, Wiedemann.

Nova Dipterorum Genera, p. 8 (1820).

Plate III., fig. 18.

With the exccption of Rhinomyza fusca, Wied., which occurs in 
Java, the five described species of this genus all belong to Cape Colony. In the South African species $R$. costata, Lw., $R$. edentula, Wied., and $R$. pusilla (Erodiorhynchus pusillus), Schin., the wings, instead of being conspicuously banded with brown as in $R$. denticornis, Wied. (Plate III., fig. 18), are hyaline or nearly so. In the case, however, of an at present undescribed species of this genus, of which the Museum has recently received a single female, from the Benue River, Northern Nigeria, between Bagana and Lokoja, March, 1907 (Dr. G. J. Pirie), the wings are marked in a very similar manner to that seen in $R$. denticornis.

Nothing is known as to the life-history of any species of Rhinomyza. Dr. Pirie's field-note on the specimen presented by him is as follows :- "Caught on a sand-bank in the evening, while we were sitting out by lamp-light : bit a European."

\section{Rhinomyza denticornis, Wiedemann.}

Aussereuropäische zweiflügelige Insekten, I., p. 111 (1828) [Silvius denticornis].

\section{Plate III., Fig. 18.}

This handsome South African species is fairly well represented in the Museum Collection, which includes a series of three males and eighteen females, from Cape Colony, Natal, the Transvaal, and Southern Rhodesia. The details as to localities, etc., are as follows. Cape Colony:-One female from Knysna ( $R$. Trimen). Natal : two males and one female from "Port Natal," 1855, 1857 (Gueinzius) ; two females from Durban (W.L.Distant) ; one female from Malvern, and three females from Karkloof, February, 1897 (G. A. K. Marshall); one female from Durban, January 10th, 1899, "caught in train to Pietermaritzburg" (Captain S. R. Christophers, I.M.S.). Transvaal : a female from Johannesburg, 1905 (A. J. Cholmley); a male and female without precise locality, 
1906 (A. J. Cholmley) ; two females from Bloksberg, Johannesburg, 1907 (C. H. Pead). Southern Rhodesia : one female from Salisbury, Mashonaland, December, 1899 (G. A. K. Marshall). The locality of one female is unknown.

\section{Genus CADICERA, Macquart.}

Mémoires de la Société Impériale des Sciences, de l'Agriculture, et des Arts de Lille, Année 1854, II ${ }^{\mathrm{e}}$ Série.- $\mathrm{I}^{\mathrm{er}}$ Vol., p. 42 (1855) : Diptères Exotiques, $5^{\mathrm{e}}$ Supplément, p. 22 (1855).

Plate III., Figs. 19-22.

So far as at present known, this genus consists of eight species of dusky-winged flies, in which the head is characteristically flattened from front to rear, the proboscis more or less elongate, and the abdomen strongly convex above and, at least anteriorly, usually broad. With the exception of one species, which occurs in the Nyasaland Protectorate, the genus has hitherto been met with only in South Africa. No observations appear to have been made as to the habits or life-history of any of the species.

Cadicera rubramarginata, Macquart.

Mémoires de la Société Impériale des Sciences, de l'Agriculture, et des Arts de Lille, Année 1854, $\mathrm{II}^{\mathrm{e}}$ Série.- $\mathrm{I}^{\mathrm{er}}$ Vol., p. 43 (1855) : Diptères Exotiques, $5^{\ominus}$ Supplément, p. 23, Tab. 1, Fig. 7 (1855).

\section{Plate III., Fig. 19.}

Owing to its peculiar coloration and markings, Cadicera rubramarginata, Macq., the type of the genus, is one of the most striking of all the Tabanidx. At present the species is represented in the Museum Collection only by a single female, from "South" Africa," before 1844 (Dr. Andrew Smith). In all probability this specimen 
was obtained in Cape Colony, and Macquart's misleading statement that the type of the species was "De l'Océanie, cap des Aiguilles," is doubtless due to a confusion between Cape Agulhas, ${ }^{*}$ the most southerly headland in Africa, and Aiguilles Point, off the coast of New Zealand.

Cadicera melanopyga, Wiedemann.

Zoologisches Magazin, Bd. I., Stück III., p. 31 (1819) [Pangonia melanopyga]: Aussereuropäische zweiflügelige Insekten, I., p. 98 (1828) [Pangonia melanopyga].

Plate III., Fig. 20.

Of this species, which, like the foregoing, occurs in Cape Colony, the Museum possesses four specimens-one male (locality unknown) and three females: of the latter, one specimen was obtained in "South Africa," before 1844 (Dr. Andrew Smith); another, which bears no more precise indication of its origin than the word "Africa," was acquired by purchase in January, 1846 (ex Colonel Whitehill's Collection); and the third was taken at Deelfontein, Cape Colony, on December 20th, 1902 (presented by Colonel A.T. Sloggett, C.M.G., R.A.M.C.).

Cadicera chrysostigma, Wiedemann.

Aussereuropäische zweiflügelige Insekten, I., p. 100 (1828) [Pangonia chrysostigma].

Plate III., Fig. 21.

This handsomely marked species, the type of which was obtained at the Cape of Good Hope, is represented in the Museum Collection

* Agulha $=$ needle (Portuguese). 
by four females, of which two are without precise localities or other data, while the remaining two were obtained at Stellenbosch, Cape Colony, in December, 1862 ( $R$. Trimen). In addition to the two patches of chrome-yellow hair on the upper side of the abdomen, the female exhibits two pairs of similar patches on the ventral surface.

Cadicera quinquemaculata, Austen.

Annals and Magazine of Natural History, Ser. 8, Vol. I., p. 209 (1908).

Plate III., FIG. 22.

Only two specimens, both females, of this prettily marked species have as yet been received by the Museum : of one of these the origin is unknown; the other is from Pirie Bush, near King William's Town, Cape Colony (A. N. Stenning). The banded tibiæ are sufficient to distinguish $C$. quinquemaculata from all other species of the genus at present described.

Genus PANGONIA, Latreille.

Histoire Naturelle, Générale et Particulière des Crustacés et des Insectes, T. III., p. 437 (1802) [Pangonius].

Plate III., fig. 23-Plate V., Fig. 34.

The genus Pangonia, Latr., in its wider sense* includes some fifty described species which occur in the Ethiopian Region. Of

* The genus is divided as follows:-

Wings with first posterior cell closed :-

Eyes bare .. Genus Pangonia, Latr.

Eyes hairy . " " "

Wings with first posterior cell open :-

Eyes hairy .. Genus Diatomineura, Rond.

Eyes bare .. " " " Subgenus Corizoneura, Rond.

The subgenus Erephopsis occurs chiefly in Australia and South America; no specios has yet been met with in Africa. 
these, all, with the exception of P. barbata, Linn., and P. fulvifascia, Walk.,-both of which are found in Cape Colony and belong to Diatomineura, Rond., sensî stricto (having hairy eyes and the first posterior cell in the wings open),-belong either to Pangonia, sensî stricto (in which the eyes are bare and the first posterior cell closed), or to the subgenus Corizoneura, Rond., of the genus Diatomineura, Rond., characterised by the eyes being bare and the first posterior cell open : the species of Corizoneura occur chiefly in South Africa. So far as it is possible to judge from the material at present received by the Museum, species of Pangonia would appear to be fairly common in Central, East, and South Africa (where Westermann long ago observed that Pangonia was more numerous than Tabanus), and rare in West Africa. It may be noted, however, that $P$. rüppellii, Jaenn., and a new and allied species have recently been met with in Northern Nigeria, while Surcouf has founded the subgenus Subpangonia for a species described by him from French Congo; two specimens of a species apparently nearly akin to the latter, and characterised by the possession of a relatively short, thick, fleshy proboscis, with remarkably elongate labella, were taken at Obuasi, Ashanti, in June, 1907, by Dr. W. M. Graham.

The slender, elongate proboscis, which is characteristic of the genus, varies greatly in length according to the species, from $2.5 \mathrm{~mm}$. in the case of the little South African Pangonia (Corizoneura) directa, Walk., to $26 \mathrm{~mm}$. (just over 1 inch) in the case of $P$. gulosa, Wied. (Plate IV., fig. 29), and $39 \mathrm{~mm}$. (or rather more than $1 \frac{1}{2}$ inch) in that of $P$. rostrata, L. ; in the two last-mentioned species, both of which, like $P$. directa, occur in Cape Colony, the proboscis is much longer than the body. If a number of specimens of any species but one with a relatively short proboscis be examined, it will generally be found that the proboscis varies in length in different individuals. In a paper on Brasilian Tabanidæ, Dr. Lutz has pointed out that this is due to the fact that the labium is protrusible and retractile, the base, when the labium is retracted, being spirally coiled within the buccal cavity; $\dagger$ this condition is found in all

$+C f$. Dr. Adolpho Lutz, "Beitraege zur Kenntniss der brasilianischen Tabaniden." Revista da Sociedade Scientifica de Säo Paulo, No. 1, p. 24 (June, 1905). 
species in which the facc is conically produced, although the facial prolongation docs not serve to accommodate the basal portion of the proboscis when retracted. Lutz considers that the possession of a very long protrusible proboscis points to a liquid diet other than blood, and from his own observations he doubts whether species in which such an organ exists bite and suck blood on the wing. As is mentioned below in the notes on Pangonia angulata, Fabr., and P. gulosa, Wied. (pp. 61, 62), according to Westermann, P. rostrata, Linn., in which the proboscis attains so remarkable a length, is one of the species most troublesome to domestic animals at the Cape, though owing to the length of the proboscis, it can only bite when on the wing. It is significant, however, that Westermann adds :- "Nevertheless this Pangonia appears to prefer to suck the nectar of flowers rather than blood, since I frequently found it on the blossoms of different species of Pelargonium : other kinds of Pangonia, on the contrary, I never met with on plants." In species such as $P$. rostrata and $P$. gulosa, the proboscis when fully or even partially extended greatly exceeds the piercing stilets in length, and this in itself would obviously offer a mechanical obstacle to the piercing of the skin of a mammal by these flies ; it is possible that when such flies appear to be attacking animals they are merely sucking up the blood flowing from wounds caused by other Tabanidæ, and this suggestion may perhaps afford the explanation of Westermann's remark that, whenever he observed $P$. rostrata round domestic animals, the latter "were in many places quite red owing to the blood that streamed from the wounds caused by the flies." Whatever be the case, however, with regard to species in which the proboscis is exceptionally long, it would appear that others, at any rate occasionally, bite and suck blood on the wing. Thus, a specimen of the new species near P. rüppellii, Jaenn., already alluded to, from South Bornu, Northern Nigeria, September, 1907 (Dr. H. A. Foy), bears the label :- "Attacking horse ; sucked blood on the wing without settling, and darted away after feeding."

The females of the majority of species of Pangonia are extremely blood-thirsty, and, while sometimes molesting human beings, are especial pests of domestic animals, which they often attack in large 
numbers. Dr. R. E. Drake-Brockman, writing from Gamoji, near Sheikh Hussein, Arussi Country, Galla Land, North-East Africa, on October 16th, 1908, with reference to Pangonia (Corizoneura) distincta, Ricardo, stated that the flies were "in hundreds, and a source of great annoyance to camels, horses, and mules." In a subsequent communication, with reference to his recent journey through the eastern and south-eastern parts of Abyssinia and the north-eastern corner of British East Africa, Dr. Drake-Brockman writes that this species "was to be seen in hundreds all over the undulating valley known as Gamoji, through which flows the river Wabi, and even up the slopes of Mt. Abul Kassim to its very summit $9000 \mathrm{ft}$. high,-Mt. Abul Kassim standing in the middle of Gamoji." "Owing to the presence of these flies in such troublesome numbers," continues Dr. Drake-Brockman, "this country is practically devoid of native villages at this time of the year. The bush seemed alive with them, but although they came hovering around human beings I did not hear of anyone being bitten by them, while on the other hand the unfortunate camels, ponies, mules, and cattle were so molested by their attentions during the heat of the day that they gave up all idea of grazing. The female alone attacks animals, the male obtaining necessary nourishment from the nectar of the wild flowers, which were plentiful in this locality in the month of October, following the rainy season. The flies commence operations about 10.0 a.m., when the sun is high, and only continue to annoy while it is shining; if the sun be masked by clouds for even a short interval they slacken their attentions, and they cease to bite altogether if the day be cloudy. Animals annoyed by them crowd together for protection, seeking the shade of the smallest bush or tree. This species, together with other members of the same family, is known to the Somalis by the name of 'Dug.' They do not consider its bite dangerous to their stock, but they avoid the stretches of country frequented by it, since the animals, instead of grazing, spend their time in keeping the flies off and in consequence lose flesh rapidly." Species of Pangonia, like other Tabanidæ, sometimes follow game ; thus, specimens of $P$. oldii, Austen (a species closely allied to $P$. zonata, 
58

Walk.,-Plate IV., fig. 25), from the vicinity of Mpimbi, Upper Shire River, 20 miles west of Zomba, Nyasaland Protectorate, taken by a native in May, 1905, and presented by Major F. B. Pearce, C.M.G., were labelled :-“ In large numbers, following the nswala antelope" [Aepyceros melampus]. Dr. J. E. S. Old, who on another occasion was himself attacked by $P$. oldii, wrote that it " makes a loud humming noise, resembling that of a large bee, and on alighting immediately thrusts its long proboscis through the skin." In a recently published paper Dr. Old stated that " Pangonia hovers for a few seconds, alights, and then deliberately punctures, like a needle, with its extraordinary proboscis."* As to native African names of Pangonia, in the Nyasaland Protectorate, according to Dr. Old, specimens belonging to the genus are apparently known to the Angoni as "Chimbu," to the Ankondi as "Mbwari," and to the Ahenga as "Nimbu."

So far as can be ascertained, no observations

Life-history. have yet been made as to the life-history of any species of Pangonia.

Although in parts of the Anglo-Egyptian

Pangonia Sudan, such as the Red Sea Province, Pangonia and Disease. magrettii, Bezzi, and $P$. rüppellii, Jaenn., are said to be connected by natives with sickness and mortality among cattle and camels, while on one occasion in New Caledonia a species of this genus is stated to have been concerned, with Stomoxys calcitrans, in the dissemination of an epidemic of anthrax, it has not yet been proved or even seriously suggested that any species of Pangonia is the regular transmitter of any micro-organism pathogenic to animals or man.

* Cf. J. E. S. Old, M.D.Brux.. " Contribution to the Study of Trypanosomiasis and to the Geographical Distribution of Some of the Blood-Sucking Insects, Etc." : Journal of Tropical Medicine and Hygiene, Vol. XII., No. 2, p. 20 (January 15 1909). 
Pangonia sexfasciata, Walker.

List of the Specimens of Dipterous Insects in the Collection of the British Museum, Part I., p. 136 (1848).

Plate III., Fig. 23.

The type of this species, from which the figure has been prepared, is still the only representative in the National Collection. It was purchased at the sale of the Children Collection in 1840, and, although without precise data, is probably from Cape Colony.

\section{Pangonia elongata, Ricardo.}

Annals and Magazine of Natural History, Ser.. 8, Vol. I., p. 54 (1908).

Plate III., Fig. 24.

Of this species the Museum possesses the type and one other female, both from Kilima-Njaro, German East Africa (Bishop Hannington). Although somewhat resembling Pangonia sexfasciata, Walk., in abdominal markings and general appearance, $P$. elongata can at once be distinguished by its smaller size and the dark tips to its wings.

Pangonia zonata, Walker.

The Entomologist, Vol. V., p. 256 (1871).

Plate IV., Fig. 25.

Pangonia zonata, Walk., which is closely allied to the somewhat larger and darker $P$. oldii, Austen, of the Nyasaland Protectorate, would appear to be a common species in Somaliland, while it also occurs in Portuguese East Africa. The following are the details 
60

with regard to the fourteen fomales by which the species is at present represented in the Museum Collection:-French Somaliland: six specimens, including the type, from Tajurrah $(J . K$. Lord). British Somaliland: two specimens from Guban, $1000 \mathrm{ft}$., May 10th, 1905, and five without precise locality (Dr. R. E. Drake-Brockman). Portuguese East Africa: one specimen without further data, 1908 (Dr. W. Woolliscroft). Although the latter specimen is not quite typical, I do not think that there can bc any doubt as to its specific identity.

Mr. Lord's note with reference to this species, as met with by him at Tajurrah, is to the effect that it is "abundant, and very tormenting to cattle"; while Dr. Drake-Brockman states that at Guban it "bites horses, mules, cattle, and camels."

Pangonia adjuncta, Walker.

List of the Specimens of Dipterous Insects in the Collection of the British Museum, Part I., p. 135 (1848).

Plate IV., Fig. 26.

The type, from which the figure was prepared, and one other female are the only examples of this species in the Museum. Both specimens were purchased at the sale of the Children Collection, in 1840, and are probably from Cape Colony, although precise data are lacking.

Pangonia angulata, Fabricius.

Systema Antliatorum, p. 91 (1805).

Plate IV., Fig. 27.

Of this species, the type of which was collected at the Cape of Good Hope more than a hundred years ago, the Museum possesses 
a male from Simon's Town, Cape of Good Hope, November, 1892 ( $P$. de la Garde, R.N.), and one female, also from Cape Colony (ex Saunders Collection). Pangonia angulata, Fabr., of which Tanyglossa cingulata, Thunb., is a synonym, presents a deceptive resemblance to $P$. conjuncta, Walk. (p. 64, Plate V., fig. 33) : the two species may, however, be distinguished by the line of median triangular spots on the abdomen of $P$. conjuncta (there being no white hairs in the centre of the hind margins of the third and fourth abdominal segments in $P$. angulata, at any rate in the female), by the colour of the light hair on the dorsum of the thorax, which is shorter and more golden-yellow in $P$. angulata, longer and paler in $P$. conjuncta, by the hair on the under side of the head in the latter species being white instead of maize-yellow, and by the head of the male being broader in $P$. conjuncta than in $P$. angulata.

Westermann,* writing of insects at the Cape of Good Hope nearly ninety years ago, stated that, while several species of Pangonia were very common, domestic animals were tormented especially by $P$. angulata, $P$. rostrata, Linn., and $P$. (Corizoneura) lateralis, Fabr., and that the latter species and $P$. angulata were cunning enough to select spots where their unfortunate victims were unable to reach them, either with head or tail. It may be added that, in Westermann's experience, species of the genus Tabanus appeared to be rare at the Cape, and were not troublesome to animals.

\section{Pangonia compacta, Austen.}

Annals and Magazine of Natural History, Ser. 8, Vol. I., p. 212 (1908).

Plate IV., FIG. 28.

In its typical form this species has as yet been met with only in Southern Rhodesia, whence the Museum has received the type and five other females, all of which were taken at Salisbury, Mashonaland, in March, 1900, and April, November, and December, 1899 (G. A.

* Germar's Magazin der Entomologie, Bd. IV., p. 427 (1821). 
K. Marshall). In the form of the subspecies centralis (Pangonia compacta centralis, Austen, Annals and Magazine of Natural History, loc. cit., p. 214), however, which differs from the typical race inter alia in its diminutive size (not exceeding $12 \mathrm{~mm}$. in length) and darker wings, $P$. compacta also occurs in the Nyasaland Protectorate, where it was encountered in some numbers on the Samulu stream, near Chibwano's, Chikala, on March 29th, 1906, by Dr. J. E. S. Old. From this locality the Museum possesses seven specimens (including the type of the subspecies), all of which were collected by Dr. Old, whose field-note is as follows:- "Numerous only near the bank, in the heat of the day; flight rapid, with humming sound much like that ordinarily associated with large common flies. Several were found together in spots only; they rushed at once to the ankles and legs, and inserted the long proboscis. Vegetation-both short and long grass ( 1 to 5 feet), scrub, and Ficus trees in the neighbourhood, and low green trees fairly thick on the banks."

\section{Pangonia gulosa, Wiedemann.}

Aussereuropäische zweiflügelige Insekten, I., p. 99 (1828).

Plate IV., Fig. 29.

Pangonia gulosa, Wied., which was described from a female from the Cape of Good Hope, and belongs to the group of South African species in which the proboscis exceeds the body in length, is represented in the National Collection by a single female from Stellenbosch, Cape Colony (R. Trimen). No observations have yet been made on the habits of $P$. gulosa, but they are doubtless similar to those of the South African P. rostrata, Linn., in which the proboscis is sometimes even longer, and with regard to which Westermann* writes :- "P. rostrata (Tabanus rostr. Linn.) on account of the length of its proboscis is incapable of biting animals sitting, but can only do so on the wing ; it must however bite very severely, since 
whenever I observed it round domestic animals the poor creatures were in many places quite red owing to the blood that streamed from the wounds caused by the flies. Nevertheless this Pangonia appears to prefer to suck the nectar of flowers rather than blood, since I frequently found it on the blossoms of different species of Pelargonium : other kinds of Pangonia, on the contrary, I never met with on plants."

\section{Pangonia beckeri, Bezzi.}

Bullettino Della Società Entomologica Italiana, Anno XXXIII., p. 10 (1901): Pangonia tricolor, Austen (nomen bis lectum), Proceedings of the Zoological Society of London, 1900, p. 7, Pl. I., fig. 8 .

\section{Plate V., fig. 32.}

This handsome species has not hitherto been met with outside Somaliland, where however it would appear to be locally common and a plague to animals. In 1894 Captain (now Colonel) H. G. C. Swayne, R.E., when passing through Ogaden to the Webi Shebeli, was much pestered by this fly and an unidentified species of Pangonia, which swarmed on his camels and constantly drew blood.* According to Colonel Swayne, P. beckeri and the unknown species are called "Doog" by the Somalis, $\uparrow$ who will not allow their live-stock to graze in places frequented by these flies and Tabanus morsitans, Ricardo, a small but extremely bloodthirsty species, known to the natives as "Balaad."

The ten specimens of Pangonia beckeri in the Museum Collection include :-One female (the type of $P$. tricolor, Austen, nec Walker) from Bun Feroli, north of the Webi Shebeli, West Somaliland, June, 1895, "biting man and animals" (C.V.A. Peel); eight females from Bohodle, British Somaliland, 1903 (Veterinary-Major Appleton, A.V.D.) ; and one female from Guban, British Somaliland,

* Cf. Austen, "A Monograph of the Tsetse-Flies" (1903), p. 307, and note.

$\dagger C f$. p. 57. 
64

May 12th, 1905 (Dr. R. E. Drake-Brockman). The collector and donor of the last-mentioned specimen writes that the species " bites camels, horses, mules, and cattle."

\section{Pangonia conjuncta, Walker.}

List of the Specimens of Dipterous Insects in the Collection of the British Museum, Part I., p. 135 (1848).

\section{Plate V., fig. 33.}

The deceptive resemblance between this South African species and Pangonia angulata, Fabr. (Plate IV., fig. 27), has already been dealt with (see p. 61). Of $P$. conjuncta, Walk., of which $P$. obesa, Walk., is a synonym, the Museum possesses three males and six females, including:- Two males (one of which is the type of the species) and three females, from "South Africa," before 1844 (Dr. Andrew Smith); one female from the "Cape of Good Hope" (ex Vigors Collection), and another (the type of $P$. obesa, Walk.) from the same locality (ex Saunders Collection, collected by Drège); and one male and one female from Simon's Town, Cape Colony, October, 1894, and November, 1892 (P. de la Garde, R.N.).

\section{Pangonia rüppellii, Jaennicke.}

Abhandlungen herausgegeben von der Senckenbergischen naturforschenden Gesellschaft, Bd. VI., p. 329 (1867).

\section{Plate V., fig. 34.}

The distribution of this brightly-marked species is exceedingly wide, since in addition to Abyssinia, where the type was obtained, $P$. rïppellii is known to occur in the Angio-Egyptian Sudan, the East Africa Protectorate (British East Africa), and Northern Nigeria; while if, as seems possible, P. magrettii, Bezzi, is merely a dark form or subspecies of $P$. riippellii, Jaenn., the range of the species also includes Somaliland and Eritrea. At the present time 
P. rüppellii is represented in the National Collection by :-Three females from Samburu, East Africa Protectorate, October 30th to November 20th, 1896 (C.S. Betton); six females caught twenty miles south of Kassala, Anglo-Egyptian Sudan, August, 1899 (Bimbashi H. H. S. Morant) ; one female from the Blue Nile, AngloEgyptian Sudan, 1905 (received from Dr. Andrew Balfour); and one female from Northern Nigeria, 1908 (Dr. H. P. Lobb-presented by the London School of Tropical Medicine).

Pangonia (Diatomineura) suavis,* Loew.

Öfvers. af Kongl. Vetensk.-Akad. Förhandl., XIV., 1857, p. 337 (1858) : Dipteren-Fauna Südafrika's, p. 17 (1860).

Plate IV., Fig. 30.

Of this handsome South African species, which was originally described from Kaffraria, Cape Colony, the Museum as yet possesses only two females, both of which were taken at Potchefstroom, in the Transvaal, in 1895 (H.P. Thomasset).

\section{Pangonia (Diatomineura) brunnipennis, $\uparrow$ Loew.}

Öfvers. af Kongl. Vetensk.-Akad. Förhandl., XIV., 1857, p. 337 (1858) : Dipteren-Fauna Südafrika's, p. 18 (1860).

Plate IV., fig. 31.

Like the last, this species also belongs to South Africa, was originally described from Kaffraria, Cape Colony, and is at present represented in the Museum Collection by only two female specimens, which however in this instance were taken at "Port Natal," in 1855 and 1857 (Gueinzius).

* Owing to the first posterior cell in the wings of this and the following species (P. brunnipennis, Lw.) being open, the two species strictly belong to the genus Diatomineura, Rond., and since the eyes are bare, to the subgenus Corizoneura, Rond.

$\dagger$ See previous note. 
CHAPTER V.

\title{
Family TABANID
}

\author{
Subfamily TABANINE.
}

Plate V., Fig. 35-Plate XII., Fig. 95.

In this subfamily, as in the Tabanidæ as a whole, the vast majority of species belong to the genus Tabanus. Besides Tabanus, Homatopota, and Hippocentrum, species of which are illustrated in the plates mentioned above, the only genera of Tabaninæ at present known to occur in the Ethiopian Region are Thaumastocera, Holcoceria, and Parhomatopota, which were described in 1906 by Dr. K. Grünberg,* and still consist of single species. The genus Thaumastocera, which is nearly related to the South American Stibasoma, Schin., was founded for Thaumastocera alkwa, Grünb., a West African species, with a remarkably shaped third antennal joint, well-developed ocelli, and wings blotched and spotted with black or clove-brown; the third joint of the antenna has, at least in the female, two deep notches in its upper margin, while in both sexes the basal angle is produced into a long process reaching to the level of the penultimate annulus. Holcoceria nobilis, Grünb., the type of the genus Holcoceria, which is allied to Homatopota, is a black, elongate species, the type of which was taken at Langenburg, on the north-eastern shore of Lake Nyasa (German East Africa); it is $15.5 \mathrm{~mm}$. in length, with long and stout antennæ, a white stripe on each side of the dorsum of the thorax, and deep black wings, with a small, pale, transverse streak at the tip. Parhomatopota (for $P$. cognata, Grünb.,-German East Africa and Zanzibar) was separated by its author from Hamatopota owing to the shape of the first and third joints of the antennæ, but it is doubtful whether these characters are sufficient to warrant a generic distinction.

*Cf. K. Grünberg, "Einige neuen Tabanidengattungen des äthiopischen Faunengebiets ": Zoologischer Anzeiger, XXX. Bd., pp. 349-362, with 13 figures in text. 


\section{Genus TABANUS Linnæus.}

Fauna Suecica, p. 462 (1761).

In West Africa known as "Mangrove-flies"; elsewhere sometimes called "Hippo-flies," and in the Anglo-Egyptian Sudan termed "Seroots," or "Seruts."

Plate V., Fig. 35-Plate XI., Fig. 83.

When due allowance has been made for recognised synonyms, and after deducting forms belonging to the Mediterranean Subregion, the described African species of Tabanus at present number about one hundred and twenty, forty-eight of which are figured in this work. While there can be no doubt that many new species have still to be discovered and described, it is also possible that further researches may show that some of the names attached to species included in the total mentioned are but synonyms. Owing to the faultiness of many of the older descriptions, the paucity of plastic characters, and the fact that the body-markings are for the most part composed of fine hairs which are peculiarly liable to be rubbed off, whereby the appearance of specimens becomes much altered, it is often a matter of great difficulty to decide whether a given species of Tabanus has or has not been already described. This applies with especial force to species belonging to the $T$. secedens group (Plate VII., figs. 54, 55, and Plate VIII., fig. 57) and certain other groups of nearly allied and more or less obscurely marked forms; species with conspicuous wing-markings, such as are exhibited by $T$. fasciatus and its allies (Plate V., fig. 36, and Plate VI., figs. 40-43), are comparatively easy to identify. When distinguishing species or endeavouring to assign a number of doubtful specimens to their proper species, special attention should always be paid to the few plastic characters available. The most important of these, which are situated upon the head, are the width and shape of the front (i.e., the space between the eyes in the female), the form of the frontal callus, and the shape of the terminal 
joint of the antennæ and palpi ; it should be noted, however, that the appearance of the latter is somewhat variable, and depends to some extent upon the direction from which the palpi are viewed. The eyes, which in life are often green, bronze-green, or blue, are frequently marked with dark purplish, horizontal bands, which vary in different species, and thus afford useful distinctive characters; as already mentioned, however, the markings and original coloration of the eyes rapidly disappear after death, and are usually entirely indistinguishable in dried specimens.

With the exception of South Africa, where they do not seem to be common,* species of Tabanus are to be found in most parts of Africa; in many localities the individuals of certain species are often exceedingly abundant, and a pest to domestic and other animals, besides frequently attacking man. It may be remarked that collections made in previously unexplored localities, though usually including several species of Tabanus, do not necessarily result in the discovery of new forms, since many species of this genus, such as T. toeniola, Pal. de Beauv. (Plate VIII., fig. 61), and T. par, Walk. (Plate V., fig. 39), have an exceedingly wide distribution; thus, more than one species originally described from a specimen from Cape Colony or Natal has recently been received from Northern Nigeria or the Bahr-elGhazal, while T. ditceniatus, Macq. (Plate XI., fig. 82), besides occurring throughout the greater part of Africa, is also met with so far away as North China. On the West African rivers, where they are often called Mangrove-flies by Englishmen and Englishspeaking natives, several species of Tabanus occur. Writing from personal observation and experience in Northern and Southern Nigeria, Mr. G. C. Dudgeon says †:- "Tabanus is a genus which is represented by a large number of well-marked species on the River Niger and tributaries, as well as the other rivers along the coast. The approach of a Tabanus is made known by its loud buzzing,

* See p. 61. -Notes on Pangonia angulata, Fabr.

$\dagger C f$. G. C. Dudgeon, "Occurrence and Habits of Some Species of Human Biting Flies belonging to the families Tabanidoe and Muscidae (Glossina), from the West Coast of Africa": Journal of Tropical Medicine, Vol. IX., No. 21, p. 327 (November 1, 1906). 
but the attack is not usually made by the insect at the point upon which it at first settles. In one case I witnessed Tabanus testaceiventris, Macq.* alight upon the back of a native at the wheel of a steam launch in which I was travelling, and, although it crawled over the man's bare flesh for some time, it did not attempt to bite until it had reached the outside of a vest which he wore, when it tried to drive its proboscis through the material in order to do so. The bites of all the species I met with, and which I had personal experience of, resulted in a painful swelling, which generally subsided in a few hours. The species which gave most trouble upon the creeks of S. Nigeria were $T$. gabonensis, $\uparrow T$. thoracinus and $T$. nigrohirtus, $\ddagger$ while in N. Nigeria T. toeniola, T. fasciatus and $T$. testaceiventris* were most conspicuous. T. biguttatus, of which the male is differently marked to the female, I found upon three or four occasions in a verandah in Lokoja, but it never seemed inclined to bite, only crawling slowly about flowers or verandah posts. On two occasions I took specimens of $T$. obscurissimus upon the ground, having lost both wings. I can offer no explanation for this, although the coincidence seems rather remarkable."

The species of Tabanus deposit their white,

Life-history. brown, or black eggs in rounded masses on the leaves and stems of plants overhanging water or growing in wet ground, sometimes also on the exposed surfaces of partially submerged stones. The eggs, which are elongate spindle-shaped, are usually between 2 and $3 \mathrm{~mm}$. in length, and always deposited in several layers; a single egg-mass may contain upwards of 400 or 500 eggs, but the number is often much smaller.

The larve, which are of the usual Tabanid type and carnivorous, live in water, mud, damp earth, or sand, feeding upon other aquatic larvæ, snails, earthworms, and small Crustacea. Development is slow, and the larval stage lasts for several months; in temperate

* Probably, T. secedens, Walk. (Plate VII., Fig. 54), or T. socialis, Walk. (Plate VIII., Fig. 57).-E. E. A.

$\dagger T$. gabonensis (garonensis), Macq., is a synonym of T. secedens, Walk.-E. E. A.

$\ddagger T$. nigrohirtus, Ricardo $=T$. socialis, Walk.-E. E. A. 
climates the species of Tabanus, like those of other genera of Tabanidæ, pass the winter in this state. The pupce, which may be looked for in damp earth near the margin of water, are also of the normal type, with a pair of large, ear-shaped, prothoracic spiracles, a circlet of spines near the hind margin of each abdominal segment, and six stout teeth at the apex of the abdomen; by means of these spines and teeth the pupæ work their way up to the surface of the ground just before the adults emerge. The preliminary stages of Tabanus biguttatus, Wied. (Plate VI., figs. 44, 45), have recently been figured and described by Mr. H. H. King, of the Wellcome Research Laboratories, Gordon Memorial College, Khartoum.*

Although there is as yet no evidence that any

Tabanus and Disease. species of Tabanus is a regular disseminator of any micro-organism pathogenic to man, the results of recent experimental work by the brothers Sergent in North Africa, coupled with those obtained by Rogers and others elsewhere, $\uparrow$ tend to show that it is impossible to ignore the importance of these flies as direct transmitters of trypanosomiases affecting domestic animals. It may even be that something more than direct transmission occasionally takes place, since in Algeria Drs. Edmond and Étienne Sergent on one occasion succeeded in transmitting the Trypanosome of el debab (a camel-disease which occurs from Morocco to Syria, and more than decimates Algerian dromedaries) by means of Tabanus (Atylotus) tomentosus, Macq., when there was an interval of twenty-two hours between the bites. The Drs. Sergent, who also performed successful direct-transmission experiments with the parasite of el debab, using Tabanus (Atylotus)

* See pp. 88, 90.

$\dagger C f$. L. Rogers, M.D. "The Transmission of the Trypanosoma Evansi by Horse-flies," etc.: Proceedings of the Royal Society of London, Vol. LXVIII., pp. 163-170 (1901).-According to Bagshawe (Sleeping Sickness Bureau, Bulletin No. 5, March, 1909, p. 188), Rogers's results have recently been confirmed by Fraser and Symonds in the Federated Malay States. It is interesting to note that "with an emulsion of a species of Tabanus, made twenty-four hours after feeding [on an infected animal]. two guinea-pigs were infected" (cf. Fraser, H., M.D., and Symonds, S. L., "Surra in the Federated Malay States. With a Note on the Distribution of certain species of Biting Flies in the Federated Malay States, by H. C. Pratt, Government Entomologist," Studies from the Institute for Medical Research, Federated Malay States, No. 9, 1908) (Singapore: Kelly \& Walsh, Ltd.). 
nemoralis, Mg., as well as the species mentioned, employed laboratory animals and do not appear to have made actual experiments upon camels. According to the authors in question, however, the natives of North Africa always assert that the disease is transmitted by Tabanidæ, and camel-drivers declare that the two species used by the French scientists, which are apparently far more common in Algeria than any others, are especially dangerous to camels. The disease, which is almost invariably fatal, commits great havoc among animals that have passed the summer in a locality where Tabanids are numerous, but among others that have been kept in a place where the flies are nearly absent its incidence is slight.* In a subsequent paper $\uparrow$ the same authors proceed to the consideration of other trypanosomiases of domestic animals in Algeria, and, after giving in tabular form the results of their experiments with Tabanidæ as transmitters, write as followst:"The perusal of this table shows that the Tabanids that are most common in Algeria are able to transmit nagana, mal de la Zousfana [a trypanosomiasis of horses], and dourine by biting a healthy animal immediately after having bitten an animal having a great many Trypanosomes in its blood. A single bite is sometimes sufficient to cause inoculation (Tabanus $s p$. and nagana, 2 cases). We saw the same thing in 1904, in the case of debab. We were not able to reproduce in 1905, with the three viruses employed, the successful result obtained in 1904 with debab, i.e., the communication of infection to a healthy animal by Tabanids which had sucked infected blood about twenty-four hours previously."

In the French Sudan, according to Laveran,§ who quotes I.

* Cf. Drs. Edmond and Étienne Sergent. "El-Debab.-Trypanosomiase des dromadaires de l'Afrique du Nord": Annales de l'Institut Pasteur, T. XIX., pp. $17-48$ (1905).

$\dagger C$. Drs. Edmond and Étienne Sergent, "Études sur les Trypanosomiases de Berbérie en 1905": ibid., T. XX., pp. 665-681 (1906).

$\ddagger$ Loc. cit., p. 680 .

§ Cf. A. Laveran, Comptes Rendus des Séances de l'Académie des Sciences, T. CXXXIX., p. 661 (1904). - Since Laveran's paper, it has been shown experimentally by Dr. Bouffard that a species of Stomoxys is capable of conveying Trypanosoma cazalboui, Laveran, the parasite of souma. 
Cazalbou,* the disease of dromedaries at Timbuctoo known as mbori, and that termed soumaya or souma at Ségou, which affects horses and humped cattle coming from Macina, both of which diseases are trypanosomiases, are propagated by Tabanus ditceniatus, Macq. (Plate XI., fig. 82), and T. biguttatus, Wied. (Plate VI., fig. 45), var.

In Somaliland and elsewhere the bites of other species of Tabanus are sometimes stated by natives to be fatal to domestic animals, but the general untrustworthiness of native statements on such matters is well known; as will be seen below, in French Congo and Upper Egypt, the deaths of camels have been attributed to the attacks of $T$. toeniola, Pal. de Beauv. (Plate VIII., fig. 61).

Tabanus insignis, Loew.

Öfvers. af Kongl. Vetensk.-Akad. Förhandl., XIV., 1857, p. 341 (1858) : Dipteren-Fauna Südafrika's, p. 44 (1860).

$$
\text { Plate V., fig. } 35 .
$$

Tabanus insignis, Loew, belongs to a group of medium-sized or small species, in which the dark brown or clove-brown body bears sharply defined, whitish markings: other members of this group are Tabanus diversus, Ricardo, T. sharpei, Austen, $T$. wellmanii. Austen, and T. argenteus, Surcouf (Plate X., figs. 72-75). The range of $T$. insignis, the type of which was from Kaffraria, Cape Colony, extends at least so far north as Uganda, as shown by the localities of the five females in the Museum Collection, as to which the details are as follows:-Two females from "Port Natal," 1856-57 (R.W. Plant) ; one female from " Port Natal," 1857 (Gueinzius); one from Natal (ex Saunders Collection); and one from the Botanical Gardens, Entebbe, Uganda, September 5th, 1904 (Captain E. D. W. Greig, I.M.S.).

* Cf. L. Cazalbou, Recueil de Médecine Vétérinaire, October 15, 1904.-See also Comptes Rendus Hebdomadaires des Séances de la Société de Biologie, T. LXII., p. 1104 (1907), and Journal of Tropical Medicine and Hygiene, October 1, 1907, p. 317. 
Tabanus septempunctatus, Ricardo.

Annals and Magazine of Natural History, Ser. 8, Vol. I., p. 268 (1908).

Plate V., Fig. 36.

With Tabanus fasciatus, Fabr. (p. 78, Plate VI., fig. 40), T. brucei, Ricardo (p. 81, Plate VI., fig. 41), T. africanus, Gray (p. 81, Plate VI., fig. 42), T. latipes, Macq. (p. 84, Plate VI., fig. 43), and T. subvittatus, Ricardo (from Angola), Tabanus septempunctatus forms a group of large or moderate-sized species, characterised by the possession of more or less apple-green, ochraceous, or ochraceous-rufous bodies, strongly banded wings, black legs, and swollen front tibiæ. The present species is represented in the National Collection by five females, of which four (including the type) are from Fwambo, near the south-eastern extremity of Lake Tanganyika, North-Eastern Rhodesia, 1896 (W.H. Nutt), while the fifth is from Mazoë, Mashonaland, Southern Rhodesia, December, 1898 (G. A. K. Marshall).

Tabanus obscurissimus, Ricardo.

Annals and Magazine of Natural History, Ser. 8, Vol. I., p. 272 (1908).

Plate V., Fig. 37.

As shown by the localities of the specimens in the Museum, this dusky species has a wide range in West Africa, extending at least from the Congo Free State to Sierra Leone. The details as to the fifteen females in the National Collection are as follows.-Congo Free State : one female from Lopori River, Upper Congo, October, 1907 (Rev. W. D. Armstrong). French Congo: one female from Libreville, Gaboon River, 1899 (the type of the species), and one other female, 1900 (Dr. A. L. Bennett). Cameroon: one female, without precise data. Southern Nigeria: one female from Uwet, 
May, 1906 (G.C. Dudgeon). Gold Coast : one female from Wassau Territory, 1901 (Dr. S. H. Jones). Sierra Leone: one female from Lokkoh Creek, April, 1904 (Major F. Smith, D.S.O., R.A.M.C.); eight females from Karina District, Sierra Leone Protectorate, October-November, 1906 (Dr. H. E. Arbuckle, W.A.M.S.). On the Gaboon, according to Dr. A. L. Bennett, Tabanus obscurissimus "draws blood from man and beast."

It may be noted that $T$. obscurissimus, Ricardo, is at any rate closely allied to $T$. ianthinus, Surcouf, from the Congo Free State, and T. besti, Surcouf, from Southern Nigeria and French Congo: further study of well-preserved material is needed in order to determine whether $T$. obscurissimus, Ricardo, is really distinct from $T$. ianthinus, Surcouf, and whether the latter may not actually be identical with $T$. besti, Surcouf.

\section{Tabanus thoracinus, Palisot de Beauvois.}

Insectes Recueillis en Afrique et en Amérique, dans les Royaumes D'Oware et de Benin, A Saint-Domingue et dans les EtatsUnis, pendant les Années 1786-1797, p. 55, Diptères, Pl. I., fig. 4 (1805-1821).

Plate V., Fig. 38.

Tabanus thoracinus and the following species (Tabanus par, Walker), both of which have an exceedingly wide distribution, which probably includes the greater part of Tropical Africa, are so similar in coloration and general appearance that care is needed in order to distinguish them with certainty. Apart, however, from its considerably larger average size (which in the plate is unfortunately shown only by the line indicating the wing-expanse), T. thoracinus may be recognised by its decidedly darker wings, and by the tips of the front tibix and the whole of the front tarsi being dark brown (clove-brown), instead of, as in $T$. par, the tips of the front tibiæ and of the front tarsi being merely brownish, while the bases of the front tarsi are distinctly lighter. 
Although the species was orginally described from West Africa (Benin), the specimens of $T$. thoracinus in the National Collection show that its range extends at least from North-Eastern Rhodesia to Sierra Leone, while according to Laveran it also includes Mozambique. Atylotus notarum, Bigot, the type of which is from Assinie, Ivory Coast, West Africa, is a synonym of this species. Tabanus thoracinus is at present represented in the Museum cabinets by forty-three females, the localities, etc., of which are as follows :North-Eastern Rhodesia: Muibwe, Luencenshi River, Luena September 27th, 1904 (R. L. Harger). Uganda: Msozi, $4000 \mathrm{ft}$., February, 1903 (the late W. G. Doggett,-Delmé Radcliffe Expedition); Entebbe, March, 1903 (Dr. Baker) ; Ankole, May 9th, 1903 ; Buddu ; Kyadondo (Colonel Sir David Bruce, C.B., R.A.M.C., F.R.S.); Botanical Gardens, Entebbe, mid-day ; Fajao, and Nimule, November, 1904 (Captain E. D. W. Greig, I.M.S.) ; Buruli, in patch of forest on Lukoge River, half-way between Junda and Kisiliza, 1903, and Junda, Buruli, in banana plantation near R. Seziwa, 1903 (S. C. Tomkins, per Dr. Nabarro); Albert Lake District, 1905 (Dr. G. H. Pooley) ; Unyoro, January, 1907, "frequently seen in the Nile Province" (the late Dr. W. A. Densham). Angola: Katema's, Bihé, February, 1905, "single specimen found on edge of swampy plain" (Dr. F. Creighton Wellman). Portuguese Congo: San Salvador, between August and October, 1908 (Dr. M. Gamble). Congo Free State: Bolengi, Ubangi River, July, 1903 (Dr. E. C. Layton). Southern Nigeria : Lagos, 1899, and 1906 (Dr. W. H. W. Strachan, C.M.G.); Ologbo and River Niger, May, 1906 (G. C. Dudgeon). Northern Nigeria: R. Niger, between Baro and Lokoja, June 25th, 1906 (W. $F$. Gowers). Gold Coast: Ancobra River, "caught on dredge," April, 1907 (received from Dr. W. M. Graham, W.A.M.S.). Ashanti : Kumasi, "caught in carriers' lines," October 19th, 1907 (Dr. W. M. Graham). Sierra Leone: Kaballa, Sierra Leone Protectorate, 1908 (Dr. Murphy, per Dr. R. M. Forde).

According to Bigot, $T$. thoracinus is said to be a great pest to boatmen in Assinie. At Brazzaville, in French Congo, where the species has been taken upon cattle on November 23rd, it is stated 
to be rare at the beginning of January.* Mr. G. C. Dudgeon notes that the colour of the eyes in the living insect is emerald-green.

\section{Tabanus par, Walker.}

List of the Specimens of Dipterous Insects in the Collection of the British Museum, Part V., Supplement I., p. 235 (1854).

Plate V., Fig. 39.

Tabanus par, in addition to being one of the most widely distributed of African Tabanidæ, since its range extends from Natal to Senegal, would also appear to be usually one of the commonest species, and is almost always represented in collections of bloodsucking flies received from Tropical Africa. The characters by which this species may be distinguished from $T$. thoracinus, Pal. de Beauv., have been dealt with in the remarks on the latter (see p. 74).

The following are the localities, etc., of the sixty-five females in the Museum Collection:-Natal : two specimens (including the type of the species) collected before 1849, and one collected in 1857 (Gueinzius); two specimens from "Port Natal," 1856-1857 (R.W. Plant). "S. Africa": two specimens, 1863 (Rev. Charles Livingstone, on Dr. Livingstone's Expedition, presented by Lord John Russell). Zululand: one specimen (received from Colonel Sir David Bruce, C.B., R.A.M.C., F.R.S.); two specimens from Kosi Bay, February-March, 1906 (F. Toppin, presented by E. Warren). Portuguese East Africa: one specimen from Delagoa Bay, 1857 (R. W. Plant). North-Eastern Rhodesia: one specimen from Muibwe, Luencenshi River, Luena District, September 27th, 1904, and three specimens from Lukoka River, Kasama District, October 2nd, 1904 (R. L. Harger). Nyasaland Protectorate: one specimen from Msama's, Chikala, March 29th, 1906, and a second, without precise locality, 1907 (Dr.J. E. S. Old); one specimen from Karonga, North Nyasa, March, 1908 (the late Captain Hallam Hardy, R.A.M.C.).

* Cf. Surcouf and Roubaud, Bulletin du Muséum National d'Histoire Naturelle, Année 1908, No. 5 (Paris, 1908). 
Uganda: one specimen from Aluba's, Madi Country, Wadelai, November 1st, 1901 (C. S. Betton); three specimens from Ankole, May 9th, 1903, five from Buddu and Kyadondo, two from Entebbe, "on an ox," and two without precise localities (Colonel Sir David Bruce, C.B., R.A.M.C., F.R.S.) ; one specimen from Fajao, and one from Wadelai, November, 1904, "on cattle" (Captain E. D.W. Greig, I.M.S.) ; nine specimens from Buruli, in patch of forest on Lukoge River, half-way between Junda and Kisiliza, 1903, and one specimen from Junda, Buruli, in banana plantation near $R$. Seziwa, 1903 (S. C. Tomkins, per Dr. Nabarro); two specimens from Albert Lake District, 1905 (Dr. G. H. Pooley). East Africa Protectorate : one specimen from Njemps, and one without precise locality, 1894 (Dr. J.W. Gregory). Congo Free State: two specimens from the vicinity of the Lualaba River, Katanga District, between $9^{\circ}$ and $10^{\circ} \mathrm{S}$. Latitude, January, 1907 (Dr. A. Yale Massey). Northern Nigeria: two specimens from Zungeru, June 28th and July 3rd, 1905 (Dr. Dalziel); one specimen from the neighbourhood of Dongwan, River Ka, July 18th, and one from Katsena Allah, August, 1907 (J. Brand); one specimen from the Benue River, between Amara and Ibi, 1908 (Dr. J. McF. Pollard, W.A.M.S.). Gold Coast: one specimen from Sekondi, October 15th, 1906 (Dr. W. M. Graham, W.A.M.S.). Sierra Leone: nine specimens from Batkanu, Sierra Leone Protectorate, June, 1907, caught inside donor's house, about 150 yards from river (Dr. H. E. Arbuckle, W.A.M.S.). During the expedition of the Liverpool School of Tropical Medicine to the Gambia a specimen of this species "was caught on board a steamer plying on the Gambia River."* Within the last few years examples of Tabanus par have been received from the Bahr-El-Ghazal, Anglo-Egyptian Sudan, and it may be added that, according to Laveran, $\uparrow$ the species also occurs in Mozambique, Portuguese East Africa.

Dr. Graham states that when alive Tabanus par is of a greenishyellow colour : an examination of specimens from Northern Nigeria,

* Cf. Newstead, Dutton and Todd, Annals of Tropical Medicine and Parasitology, Series T. M., Vol. I., No. I. (February 1, 1907), p. 45.

† Comptes Rendus des Séances de l'Académie des Sciences, T. CXLIV., p. 551 (1907) 
preserved in spirit, shows that the eyes in life are bright deep green, without bands, but with a slight bronze sheen towards the edges.

Writing of this species as met with by him in French Congo, M. Roubaud says that it is "somewhat rare at Brazzaville, and is caught only in the vicinity of cattle, at the beginning of the rains, that is to say towards the end of September."*

\section{Tabanus fasciatus, Fabricius.}

Systema Entomologiæ, p. 788 (1775).

Plate VI., Fig. 40.

The affinities of this and of the three following species have already been dealt with under T. septempunctatus, Ricardo (see p. 73). T. fasciatus, Fabr., is a common West African species, the range of which -either in the form of the typical race, in that of the subspecies niloticus, Austen, or in that of forms intermediate between the two, - extends from Senegal to the Anglo-Egyptian Sudan and Uganda. Tabanus fasciatus niloticus, Austen $\dagger$ (in which the upper side of the basal portion of the front tibix is yellowish and clothed with golden hair), differs from the typical $T$. fasciatus, Fabr., " in the coloration and hairy covering of the front tibiæ (which in the typical form are entirely black and clothed exclusively with black hair), in the coloration of the middle and hind tibix (yellow or greenish-yellow instead of black or dark brown), and in the hind tibiæ on the outside having a golden instead of a black fringe." $\ddagger$ The typical race is represented in the Museum Collection by forty-seven females; the subspecies niloticus by thirty, and intermediate forms by eighteen females. Details as to localities, etc., are as follows.-

Typical Race.-Gambia, 1908 (Dr. T. Hood). Sierra Leone:

* Cf. Surcouf and Roubaud, Bulletin du Muséum National d'Histoire Naturelle, Année 1908, No. 5 (Paris, 1908).

† Second Report of the Wellcome Research Laboratories at the Gordon Memorial College, Khartoum, p. 62, Plate VI. (1906).

‡ Austen, op., cit., p. 63. 
Port Lokkoh Creek, April-May, 1904, including five specimens taken on a boat off the village of Moferri (Major F. Smith, D.S.O., R.A.M.C.) ; Port Lokkoh Creek and Rokelle River, 1905, "biting natives and cattle "(Captain (now Major) W. H. Grattan, R.A.M.C.) ; Skarcies River, Karina District, Sierra Leone Protectorate, November, 1906 (Dr. H. E. Arbuckle, W.A.M.S.); Sherbro, May, 1908 (Dr. Jackson-Moore, per Dr. R. M. Forde, W.A.M.S.), and January, 1909 (Dr. C. B. Hunter, W.A.M.S.). Northern Nigeria : Baro, R. Niger, June, 1906 (G. C. Dudgeon) ; R. Benue, between Amara and Ibi, 1908 (Dr. J. McF. Pollard, W.A.M.S.). Southern Nigeria : Lagos, 1899, 1900, 1906 (Dr. W.H.W. Strachan, C.M.G.) ; Cross River, 1906 (Dr. R. W. Gray), and June, 1908 (G. C. Dudgeon). Congo Free State: Wathen, 1892 (Miss Macomish); Leopoldville, December 16th, 1904 (Drs. Dutton, Todd, and Christy) ; R. Congo, below Basoko, $1400 \mathrm{ft}$., November, 1906 (Ruwenzori Expedition).

Forms Intermediate between Typical Tabanus fasciatus, Fabr., and T. fasciatus niloticus, Austen.-Gold Coast: Volta River, March, 1908 (G. C. Dudgeon). Northern Nigeria: R. Niger, near Baro, June 25th, 1906, and Shonga, 1907 (G. C. Dudgeon); R. Benue, between Bagana and Lokoja, March, 1907, "caught in daytime, inside canvas awning of native canoe, while travelling on river" (Dr.G.J. Pirie). Southern Nigeria: Asaba, 1895 (the late Dr. W. H.Crosse) ; Cross River, 1906 (Dr. R. W. Gray). Congo Free State: Wathen, 1892 (Miss Macomish), and 1904 (the late Rev. W. H. Bentley) ; Bolengi, July, 1903 (Dr. E. A. Layton); Leopoldville, December 8th, 1903, and February 29th, 1904 (Drs. Dutton, Todd, and Christy); Bonginda, Lulanga River, Upper Congo, August 29th, 1907, "in bedroom at night, only specimen seen" (Rev. W. D. Armstrong). Uganda: Ankole, May 16th, 1903 (received from Colonel Sir David Bruce, C.B., R.A.M.C., F.R.S.) ; Fajao, Victoria Nile, November, 1904 (Captain E. D. W. Greig, I.M.S.) ; Northern Usoga, 1906 (received from Dr. A. D. P. Hodges).

Tabanus fasciatus niloticus, Austen.-Gambia, 1906 (Dr. E. Hopkinson, D.S.O.). Northern Nigeria: R. Niger, near Bukunji, November 25th, 1906, "taken biting native canoe-man" (Major C. B. Simonds, R.G.A.); R. Benue, between Bagana and Lokoja, 
March, 1907, "caught in daytime, inside canvas awning of native canoe, while travelling on river" (Dr. G. J. Pirie); R. Benue, August, 1907, and Kwotello, R. Ka, Jega District, July 17th, 1907 (received from J. Brand); R. Benue, between Amara and Ibi, 1908 (Dr. J. McF. Pollard, W.A.M.S.). Anglo-Egyptian Sudan : Kodok, White Nile, 1900 (Lt.-Colonel R. H. Penton, D.S.O., R.A.M.C.) and December 6th, 1900 (the late Captain H. E. Haymes, R.A.M.C.); Bahr-El-Ghazal, February, 1905 (Lt.-Colonel R.H.Penton, D.S.O., R.A.M.C.) ; Abu Chok, White Nile (between Gondokoro and Taufikia), May 29th, 1905, "on boat" (Colonel G. D. Hunter, D.S.O.). Uganda: Bugaya Is., Lake Victoria, August, 1903, and Ankole, August 7th, 1903 (Colonel Sir David Bruce, C.B., R.A.M.C., F.R.S.) ; Botanic Gardens, Entebbe, September 18th, 1904 (Captain E. D. W. Greig, I.M.S.) ; Albert Lake District, 1905 (Dr. G. H. Pooley).

It may be added that, according to Laveran, ${ }^{*}$ Tabanus fasciatus, Fabr., occurs in Senegal, while Surcouf and Roubaud $\uparrow$ state that the species is very common on all the rivers in French Congo, and that it attacks human beings and cattle.

Dead specimens of $T$. fasciatus, such as that from which the figure has had to be prepared, unfortunately afford but a poor idea of the brilliancy of the colours in the living insect, as to which Dr. J. L. Todd writes as follows :- "While living this fly is a very beautiful object. The eyes are a bright, metallic, pea-green, and the colours of the body are very much brighter than in dried specimens." Writing of the habits of the species, as observed by him on the Gambia and in the Congo Free State, during the expeditions of the Liverpool School of Tropical Medicine, Dr. Todd says :- " This insect was seen only near water. Most of the specimens were taken while travelling by steamer or in canoes. Two specimens were, however, caught in the houses of Europeans. . . . . It flies strongly, and is often seen on board steamers over 100 yards from the river's bank."§ Dr.

* Comptes Rendus des Séances de l'Académi des Sciences, T. CXLIV., p. 547 (1907).

$\dagger$ Bulletin du Muséum National d'Histoire Naturelle, Année, 1908, No. 5 (Paris, 1908).

‡ Annals of Tropical Medicine and Parasitology, Series T. M., Vol. I., No. I., p. 44 (February 1, 1907).

\& Ibid. 
Arbuckle states that in the Sierra Leone Protectorate $T$. fasciatus "bites very viciously, often causing blood to flow from the punctured spot." Dr. G. J. Pirie describes the flight of the insect as "very noisy," and its bite as "rather painful."

Tabanus brucei, Ricardo.

Annals and Magazine of Natural History, Ser. 8, Vol. I, p. 268 (1908).

Plate VI., Fig. 41.

This large and easily recognisable species has hitherto been met with only in Uganda and the Katanga District of the Congo Free State. The Museum possesses five females (including the type), from Ankole, Uganda Protectorate, May 9th, 1903 (received from Colonel Sir David Bruce, C.B., R.A.M.C., F.R.S.). The eyes of $T$. brucei in life are deep green, without bands.

Tabanus africanus, G. R. Gray.

Griffith's "Animal Kingdom " (Cuvier), Vol. 15, p. 794, Plate 114, fig. 5 (1832) : redescription by E. E. Austen, Second Report of the Wellcome Research Laboratories at the Gordon Memorial College, Khartoum, p. 64, fig. 28 (1906).

\section{Plate VI., Fig. 42.}

This easily-recognised species, which is certainly one of the handsomest of the African representatives of the genus Tabanus, can be confused only with T. latipes, Macq. (p. 84, Plate VI., fig. 43), to the notes on which the reader is referred for the distinctive characters. As shown by the extensive series of specimens (two males and forty-four females) in the Museum, the range of $T$. africanus extends from Natal to the East Africa Protectorate and the Nile Provinces of the Anglo-Egyptian Sudan, and westwards 
at least as far north as Angola. The species is also found in the French Sudan, in the vicinity of Lake Chad, where, according to Dr. Kerandel, it feeds on hippopotami as well as cattle, and is known to the natives as Kendogo, or Ter al Diamouss.* In West Africa, somewhere to the north of Angola, and at any rate in Nigeria, $T$. africanus would appear to be replaced by $T$. latipes, which apparently is distributed across the continent from west to east, or at least to Senaar, on the Blue Nile, so that it may eventually be found that the two species occur together in Kordofan, or the Bahr-ElGhazal. The localities, etc., of the specimens of $T$. africanus at present in the National Collection are as follows.-

"S. Africa," 1863 (Rev. Charles Livingstone, on Dr. Livingstone's Expedition, presented by Lord John Russell). Natal : precise locality uncertain, 1853 (R.W. Plant); Malvern and Isipingo, February, 1896 (G. A. K. Marshall). Zululand, precise locality uncertain (Colonel Sir David Bruce, C.B., R.A.M.C., F.R.S.); Kosi Bay, Zululand, February-March, 1906 (F. Toppin). Portuguese East Africa: Delagoa Bay, 1857 (R.W. Plant), and 1901 (from the late Dr. E. A. Heath's collection); Marracune, Lorenzo Marques, January 7th and 13th, 1907, "rather uncommon," and Inyack Island, Delagoa Bay, January 16th, 1907 (F. D. McMillan); Mouth of R. Zambesi, 1897 (Westcott); marsh near Mount Morambala, Lower Shirè River, 1.0 p.m., February 16th, 1906 (one specimen alighted on donor's nose, two others seen-Dr.J.E.S. Old). Nyasaland Protectorate: Lake Nyasa, 1887 (Bellingham); Fort Johnston, January 12th, Upper Shirè River, January 14th and 20th, Nkata Bay, Lake Nyasa, January 14th and 15th, 1906 (E. L. Rhoades); South Nyasa, May 1st, 1908 (the late Captain Hallam Hardy, R.A.M.C.). German East Africa: Kilima-Njaro, 1887 ( $F . J$. Jackson, C.B., C.M.G.). East Africa Protectorate: Witu, 1891 (Imperial British East Africa Company); Ngatana and Leikipia, 1894 (Dr. J. W. Gregory); Samburu, November, 1896 (C. S. Betton); Yoiuti, Juba River (about 20 miles from its mouth), February, 1905 (Major L. H. R. Pope-Hennessy, D.S.O.). Uganda: Buvuma I., Lake

* Cf. Surcouf and Roubaud, Bulletin du Muséum National d'Histoire Naturelle, Annéo 1908, No. 5 (Paris, 1908). 
Victoria, 1903, "from long grass" (Colonel Sir David Bruce, C.B., R.A.M.C., F.R.S.) ; Mruli, Victoria Nile, January, 1907, "single specimen, taken in tent" (the late Dr. W. A. Densham). AngloEgyptian Sudan: White Nile, about 1862 (Consul Petherick); Bahr-El-Ghazal, February, 1905 (Lt.-Col. R. H. Penton, D.S.O., R.A.M.C.). Angola: Kinsembo (presented by the late F. Smith, 1872).

From a note kindly supplied by Dr. J. E. S. Old, it would appear that the eyes of this species in life are greenish blue. The late Dr. Densham observed that "the translucent wing-tip, with dark markings at one side, gives $T$. africanus a curious appearance when on the wing." Mr. F. D. McMillan has been good enough to furnish the following note on Tabanus africanus, as observed by him in Lorenzo Marques, Portuguese East Africa:- "Native name Hla (pronounced Shlā) Bowu. A rather uncommon fly, much dreaded by the natives. It attacks in the heat of the day, when the observer is stationary, flies silently, and nearly always goes for the neck and back. Its bite causes a sharp smart, which soon goes off, leaving a peculiar swelling half an inch in diameter, which gradually increases to the size of a shilling. The centre is not raised, but only the circumference, which looks like a small ring under the skin, with a small dot where the bite was. It is very painful to the touch, and the individual bitten invariably gets a temperature as high as $104^{\circ}$, which, however, passes off in about six hours. The natives, who formerly used to smear their spears with squashed, dead Hla-flies as a poison, say that three bites will kill a man, and that the victim goes mad." According to Mr. C. E. Lyall*:-“In some localities on the White Nile, T. africanus - and probably other species of similar appearance-is known to the natives as Ter-el-gufar ("bird' or 'flying thing of camel sickness '), owing to the belief that exists among them that it is the cause of the common camel disease."

* Cf. H. H. King, Third Report of the Wellcome Research Laboratories at the Gordon Memorial College, Khartoum, p. 210 ([1908] 1909). 
Tabanus latipes, Macquart.

Mémoires de la Société royale des Sciences, de l'Agriculture et des Arts de Lille, 1838, $2^{\mathrm{e}}$ partie, p. 123 (1838) : Diptères Exotiques, T. I., $1^{\text {re }}$ partie, p. 119 (1838).

Plate VI., Fig. 43.

As already stated in the notes on Tabanus africanus, Gray, T. latipes, Macq., would appear to be the West African representative of that species, although, since T. latipes has been met with in Senaar, it evidently extends across the continent, so that the areas of the two species probably overlap in Kordofan or the Bahr-El-Ghazal. On comparing figs. 42 and 43 , Plate VI., it will be seen that the present species agrees with $T$. africanus in the coloration and markings of the body, as also in the general arrangement of the wingmarkings, but that it is distinguished by the brown on the costal border of the wing not being continued beyond the stigma (there being no infuscation at the tips of the second and of the upper branch of the third vein), and by the brown band across the middle of the wing not reaching the hind margin. According to Mr. G. C. Dudgeon, the eyes in life are "deep blue."

Tabanus latipes, which was originally described from Senegal, is also found in southern Mauritania, to the north of the Senegal River, in the Brakna and Tagant countries.* With the exception of two specimens from Senaar, the fourteen females by which the species is at present represented in the National Collection are all from Northern Nigeria. The following are the details as to localities, dates, and collectors.-

Northern Nigeria : near Pawa, on the Katsina-Sokoto Boundary, August, 1904 (the Acting Resident of Kano, per Sir F. D. Lugard, K.C.M.G.); R. Kaduna, near Mureji, June 22nd, 1906, and R. Niger, between Baro and Lokoja, June 25th, 1906 (W. F. Gowers); R. Kaduna and R. Niger, June, 1906 (G. C. Dudgeon); R. Benue, p. 547 (1907). 
August, 1907 (J. Brand) ; R. Benue, between Amara and Ibi, 1908 (Dr. J. McF. Pollard, W.A.M.S.). Anglo-Egyptian Sudan : Blue Nile, Senaar, September, 1902 (Major H. N.Dunn, R.A.M.C.).

It may be worthy of note that the female from the vicinity of Pawa, Northern Nigeria, was received with four specimens of Tabanus toeniola, Pal. de Beauv. (Plate VIII., fig. 61), and a fifth Tabanus too much damaged to be determinable, with the following general label by the Acting Resident of Kano : "Wayam Fly : kills horses."

Tabanus biguttatus, Wiedemann.

Aussereuropäische zweiflügelige Insekten, II., p. 623 (1830).

Plate VI., figs. 44 (male) and 45 (female).

This quite unmistakable fly is distributed from Cape Colony to the Anglo-Egyptian Sudan and Abyssinia, and north-westwards at least as far as the Lake Chad region of the French Sudan, Senegal, and Southern Mauritania, while it also occurs to the east of the Red Sea, in the Peninsula of Aden. In West Africa, as also in the Anglo-Egyptian Sudan or elsewhere, the typical race represented in the figures may, at least in the case of the female, be locally replaced or accompanied by one or other of certain forms, which differ from it chiefly in the colour of the palpi and of the hair on the head and back of the thorax. As will be seen from the figures, Tabanus biguttatus exhibits a striking sexual dimorphism in the markings of the body; in the female sex, the hair clothing the head and back of the thorax may be either golden-yellow (as in fig. 45), or whitish yellow. Except for a fringe of whitish hair at the tip, the upper side of the abdomen in the female is usually entirely dark, as shown in the figure, but it occasionally happens that spots are present, similar to those of the male. Thus, two females in the Museum collection, from the Bahr-El-Ghazal, Anglo-Egyptian Sudan, and the Hawash Valley, Abyssinia, have the abdomen spotted as in the male, though in the case of the Abyssinian specimen the spots are 
somewhat more triangular and elongate in shape ; in addition, these two females also show traces of a patch or streak of yellowish hair in the median line on the second and fifth abdominal segments.* In the Anglo-Egyptian Sudan, to judge from the specimens of the two forms received up to the present time, females with pale hair on head and thorax would appear to be more common than those with golden-yellow hair; the same variation is seen in females from Uganda, and a female from the Umfuli River, Natal, also has the hair on head and thorax distinctly paler than in other females from the same colony.

Exclusive of a male and two females of the typical race, from Haithalhim, near Aden, Arabia, March 20th and 23rd, 1895 (Lt.-Col. Yerbury), the Museum at present possesses sixty-four specimens of $T$. biguttatus, including fourteen males and fifty females. It will be observed that far more males have been collected than is usually the case where Tabanidæ are concerned, and it may also be noted that the species was originally described from a male (from the Cape of Good Hope), whereas the males of Tabanidæ generally are so rare in collections that by far the greater number of descriptions have had to be drawn up from the female alone. During the French Expedition to French Congo for the study of Sleeping Sickness, four males of $T$.biguttatus were taken at Brazzaville, on January 7 th and 12th, 1907, " at the water's edge, trying to drink on the ground," while a fifth was caught " at a lamp, at 6.30 p.m., during a tornado." $\dagger$ In the Anglo-Egyptian Sudan Mr. H. H. King $\ddagger$ has observed that " males appear to be more plentiful than females," and it would be interesting to know the reason for the unusual abundance of males in this species.

The details as to the localities, etc., of the specimens in the Museum are as follows.-

Cape Colony : Port Elizabeth, 1891 (Dr. H. A. Spencer). Natal :

* Coloured figures of some of these variations in marking are given by Mr. Harold H. King, in the Third Report of the Wellcome Research Laboratories at the Gordon Memorial College, Khartoum, Pl. XXV., figs. 2 and 3, 1909. (Although dated " 1908," on the title-page, this Report was in reality not published until February, 1909).

$\dagger C f$. Surcouf and Roubaud, Bulletin du Muséum National d'Histoire Naturelle Année 1908, No. 5 (Paris, 1908).

$\ddagger$ See below. 
locality uncertain (Gueinzius, 1849, and $R$.W. Plant, 1855) ; Umfuli River and Isipingo, September, 1895, and February, 1896 (G. A. K. Marshall); Alexandra Park, Pietermaritzburg, May 5th, 1904 (E. Warren). Portuguese East Africa: Delagoa Bay, 1857 (R. W. Plant); Lorenzo Marques and Inyack I., January, 1907 (F.D. McMillan); Rovuma River, 1863 (Dr. Livingstone); Mouth of the Zambesi River, 1897 (Westcott) ; Govuro, Sabi River, Mozambique, December 27th, 1907 (Mrs. H. Zurcher). Nyasaland Protectorate : Shirè Highlands and Blantyre District, February and June, 1905 (Dr. J. E. S. Old) ; Nkata Bay, Lake Nyasa, April 15th, 23rd, and 25th, 1906 (E. L. Rhoades) ; Lintipe River, Lake Nyasa, December 12 th, 1908 (the late Captain Hallam Hardy, R.A.M.C.). Uganda : Busoga, 1903, "from swamp" (Colonel Sir David Bruce, C.B., R.A.M.C., F.R.S.) ; Northern Usoga, 1906 (received from Dr. A. D. P. Hodges); Nimule, Nile Province, 1907 (a single male, taken in tent; no other specimen seen-the late Dr. W. A. Densham). East Africa Protectorate: Athi-ya-Mawe, 1899 (C. S. Betton). Abyssinia: Hawash Valley, 1901 (A. E. Pease). Anglo-Egyptian Sudan : White Nile, about Lat. $11^{\circ}$ N. March 20th, 1900 (Captain S. S. Flower) ; White Nile, 1900 (Major H. N. Dunn, R.A.M.C.); Kodok, 1900, and Bahr-El-Ghazal, February, 1905 (Lt.-Col. $R$. H. Penton, D.S.O., R.A.M.C.) ; 30 miles south of Sobat River, on boat on White Nile, 1903 (the late Captain H. E. Haymes, R.A.M.C.); White Nile, north of Kodok, on steamer, November 6th, 1905 (Major G. Dansey Browning, R.A.M.C.). Congo Free State : near Lualaba River, Katanga District, between $9^{\circ}$ and $10^{\circ}$ S. Lat., January, 1907, on buffalo [Bubalus caffer, Sparrm.] (Dr. A. Yale Massey). Southern Nigeria: Cross River, June, 1908 (G. C. Dudgeon). Northern Nigeria: Illorin, August, 1904 (" not noticed until about the middle of June"-received from Sir F. D. Lugard, K.C.M.G.) ; Zungeru, July 2nd, 1905 (Dr. Dalziel) ; Borgu, August, 1906 (Dr. R. F. Williams); Lokoja and vicinity, June, 1906 (G. C. Dudgeon); Kontagora, February 1st, and Jega, June 11th, 1907 (J. Brand); Benue River, between Amara and Ibi, 1908 (Dr. J. McF. Pollard, W.A.M.S.). Gold Coast : Gambaga, Northern Territories, June 2nd, 1904, " on cow, grazing in low bush" 
(J. O'Kinealy). Gambia: precise locality uncertain, March, 1908 (Dr. T. Hood, S.M.O.).

According to Mr. G. C. Dudgeon, the eyes of Tabanus biguttatus in life are dark brown. Mrs. H. Zurcher, writing from Mozambique, notes that the species is able to bite freely through all clothes; in the Shirè Highlands, Nyasaland Protectorate, in February, 1905, Dr. J. E. S. Old found T. biguttatus apparently feeding on sable antelope (Hippotragus niger, Harris), and there can be no doubt that it attacks big game and domestic animals of all kinds.

With reference to this species in Lorenzo Marques, Mr. F. D. McMillan writes as follows :- "Native name Imvu Bowu. Hippo fly : caught and seen in great numbers on the banks of large rivers, and on boats and sails. Apparently bites only in the evening and night. By day flies with a distinct low hum; at sunset and on through the night flies absolutely silently, like a bat. Hovers about one inch from the person whom it is attacking, and quietly settles. Although so large, one does not feel it alight ; nothing is felt until it flies away, when there is a sharp smart, followed by intense irritation lasting some hours ; this gradually passes off, leaving a pink spot (on Europeans, a grey spot on Kaffirs). If care be not taken to prevent the place from getting scratched or burnt by the sun, a nasty festering sore results : three or four bites will quite upset a native, and apparently take all his strength from him. The Imvu occurs all through the year, but is most troublesome from December to February."

The following interesting account by Mr. Harold H. King of the habits and life-history of Tabanus biguttatus, as observed by him in the Anglo-Egyptian Sudan, is taken from the recently published Third Report of the Wellcome Research Laboratories.*

"The adults," writes Mr. King, "may usually be found resting on the trunks and larger branches of trees. Males appear to be more plentiful than females. On the approach of cattle, the latter dart off and attack them, but were rarely seen to follow them for any distance. Both sexes are very wary, and are not easily captured.

* Third Report of the Wellcome Research Laboratories, at the Gordon Memorial College, Khartoum, 1909. Pp. 213, 214, "Report on Economic Entomology," by Harold H. King. Pl. XXV., figs. 1, 5, 6, 8, 9 (egg-batch on stem of grass, larvæ, and details of larval structure). 
"The eggs are deposited in a rounded mass on grass and reeds overhanging a pool. One egg mass that was counted contained about 450 eggs. The entire act of oviposition was not timed, but it is a lengthy proceeding, and occupies well over half-an-hour. When a female is ovipositing, although usually exceedingly shy, the stem on which she is resting may be plucked and carried away, or put into a bottle without disturbing her. Having deposited her eggs, she covers the mass with a creamy-white secretion, which turns black after a short time.

"The eggs under observation hatched in about eight days, but possibly under natural conditions, exposed to the sun, the incubation period would be shorter. On hatching, the larvæ fell into the water, swam to the sides, and buried themselves in the mud.

"The larvæ can only swim on the surface of the water, and progress either by a telescopic movement or by lashing vigorously from side to side.

"Several methods of rearing them were tried. The majority were placed in a large glass vessel containing mud, living grass, and water. Some were put into jars containing only water, others in dishes containing moist sand, others, again, in vessels containing sand and water so arranged that there was a pool at one end of the vessel and moist sand at the other.

"The larvæ in the vessel containing mud, grass, and water did well, but many were devoured by predaceous insects-e.g., dragon-fly larvæ-introduced by accident in the mud and water, and others perished owing to the grass dying and fouling the water during transit. Eventually sand and water in Petri dishes was found to be best, as it could be kept clean and the larvæ easily located when wanted.

"At first they were fed on tiny crustaceans dredged from rain pools, but during transit, when these could not be obtained, scraps of freshly-killed raw meat and congealed blood from the bodies of gorged mosquitoes were substituted. After arriving in Khartoum their diet consisted of earth-worms, as a plentiful supply of these could always be procured.

"They grew very slowly and at greatly varying rates. Two 
larvæ hatched from one egg batch on 11th June measured respectively, five weeks later, $4 \mathrm{~mm}$. and $15 \mathrm{~mm}$. Owing to their telescopic nature it was exceeding difficult to measure them accurately, so these figures must be taken as merely approximate.

"They did not appear to be cannibalistic in their habits, as several of various sizes were reared in the same dish and sometimes kept short of food, but were never seen to attack each other. When one died, however, its comrades usually devoured it.

"When not feeding they spent most of their time buried in the sand, with just the tips of their respiratory syphons showing. If the sand was allowed to dry they became very restless, and would make continual efforts to escape from their jars until water was given them again.

"Early in August, when they were about eight weeks old, they ceased feeding, and were then transferred to jars containing sand to a depth of $6 \mathrm{~cm}$. They descended to the bottom of these jars, and were still there when, some six weeks later, I went to England on leave.

"I returned to Khartoum on 28th January, and the jars then contained several dead adults-all males-a few dead pupæ and larvæ, and a single live larva. This last perished early in February without having reached the pupal stage. The empty pupal cases were all sticking up out of the sand, the pupæ having evidently worked their way up from the bottom of the jars by means of their abdominal spines. In several cases the old larval skin had remained attached to the caudal teeth of the pupal case.

"The eggs from which these seroots were bred were obtained in the marshes in the vicinity of Taufikia." 
Tabanus maculatissimus, Macquart.

Mémoires de la Société Royale des Sciences, de l'Agriculture et des Arts de Lille, 1838, $2^{\mathrm{e}}$ partie, p. 125 (1838) : Diptères Exotiques, T. I., $1^{\text {re }}$ Partie, p. 121, Pl. 17, fig. 2 (1838).

\section{Plate VI., Fig. 46.}

So far as is known at present, Tabanus maculatissimus, Macq., is found from Cape Colony to the Nyasaland Protectorate and the Congo Free State, while T. maculatissimus irroratus, Surcouf, a form without orange hair at the extremity of the abdomen, and with larger brown blotches at the tips of the wings, occurs in French Congo. A glance at the figure will suffice to enable the reader to identify this species, which may be regarded as an offshoot of the group represented by the four species illustrated in the upper half of Plate VI., since, although the front tibiæ are distinctly swollen, the ground-colour of the body is dark brown, the legs are pale instead of black, as is usually the case in the group referred to, and the wings instead of being banded are blotched or speckled with brown. The localities, etc., of the seven females representing the species in the National Collection are as follows._- "S. Africa," before 1844 (Dr. Andrew Smith). Cape Colony: Kaffraria, 1878 (F. P. Mansel Weale). Natal: Karkloof, February, 1897 (G. A. K. Marshall). Nyasaland Protectorate : Shirè Highlands, February, 1905 (Dr. J. E. S. Old). Congo Free State : near Lualaba River, Katanga District, between $9^{\circ}$ and $10^{\circ}$ S. Lat., "on buffalo" [Bubalus caffer, Sparrm.] (Dr. A. Yale Massey).

Tabanus pluto, Walker.

List of the Specimens of Dipterous Insects in the Collection of the British Museum, Part I., p. 153 (1848).

Plate VI., Fig. 47.

The unusual appearance of this species, due to the presence of 
a large chrome-yellow or sulphur-yellow patch on each side of the abdomen, renders it easily recognisable; unfortunately in the figure these patches are largely obscured owing to the wings having been drawn in the resting position. The range of Tabanus pluto, which, under the name Tabanus leucaspis, was re-described by Van der Wulp from a specimen from the Gold Coast, extends, so far as our present knowledge goes, from Sierra Leone to Portuguese Congo and Uganda. The following are the data as to locality, etc., with reference to the ten females in the Museum Collection.-Sierra Leone: (type) precise locality unknown, 1838 (Rev. D. F. Morgan). Liberia: collected on coast during surveying cruise of H.M.S. Mutine, 1908 (Surgeon A. McCloy, R.N.). Northern Nigeria : Benue River, August, 1907 (J.Brand). Congo Free State : Kisantu, Cataract Region, R. Congo, November 26th, 1903, and Leopoldville, January 25th, 1904 (Drs. Dutton, Todd, and Christy). Portuguese Congo: San Salvador, 1909 (Dr. M. Gamble). Uganda : Busoga, September 17th, 1903 (Colonel Sir David Bruce, C.B., R.A.M.C., F.R.S.). In French Congo, where it is said to attack human beings on the rivers, T. pluto was collected at Brazzaville, on September 20th, 1907, by M. E. Roubaud, while at the end of December a specimen was taken on a horse suffering from trypanosomiasis.*

Tabanus ruficrus, Palisot de Beauvois.

Insectes Recueillis en Afrique et en Amérique, dans les Royaumes d'Oware et de Benin, A Saint-Domingue et dans les EtatsUnis, pendant les Années 1786-1797, p. 55, Dièptres, Pl. I., fig. 3 (1805-1821).

Plate VII., Fig. 48.

The range of this locally common West African species extends at least from the Sierra Leone Protectorate to the Congo Free State. The localities, etc., of the seventeen females in the National Collection

* Cf. Surcouf and Roubaud, Bulletin du Muséum National d'Histoire Naturelle Année 1908, No. 5, p. 221 (Paris, 1908). 
are as follows.-Gold Coast : Cape Coast Castle (F. Scott) ; Wassau Territory, 1901 (Dr. S. H. Jones); Sekondi, October 23rd-31st, 1906 (Dr. W. M. Graham, W.A.M.S.). Southern Nigeria: Cross River, 1906 (Dr. R. W. Gray). Congo Free State: Bolengi, Upper Congo, July, 1903 (Dr. E. A. Layton); Lutete, November 20th, 1903 (Drs. Dutton, Todd, and Christy). A female, taken at Bo, Sierra Leone Protectorate, in October, 1908 (Dr. H. E. Arbuckle, $W . A . M . S$.$) , is in the possession of the London School of Tropical$ Medicine.

Of Tabanus ruficrus, as met with in the Congo Free State by the members of the expedition of the Liverpool School of Tropical Medicine to the Congo, 1903-05, Dr. Todd writes*:- " This fly was caught only near water, usually while attempting to bite passengers in canoes or steamers. . . . . They fly very rapidly and strongly, and have been seen at over 100 yards from the banks of the river. They seem to be very local. For example, near Pania Mutombo ten or a dozen were seen at the same moment darting about a canoe. A little further down the river towards Lusambo none were seen for miles." Writing with reference to this species in French Congo M. Roubaud says† :- "Common, especially in October, disappearing during the remainder of the year, then reappearing in October at Brazzaville, and invading houses and stables; bites human beings on the rivers."

It may be noted that Tabanus pervasus, Walk., and $T$. deyrollei, Big., are synonyms of this species.

\section{Tabanus brumpti, Surcouf.}

Bulletin du Muséum d'Histoire Naturelle, Année 1907, No. 1, p. 42 (Paris, 1907).

\section{Plate VII., fig. 49.}

Although described by its author as a "variety" of the foregoing,

* Cf. Newstead, Dutton and Todd, Annals of Tropical Medicine and Parasitology, Series T. M., Vol. I., No. I., p. 45 (February 1, 1907). The species is erroneously styled "Tabanus rufipes, Macq.," which is a synonym of $T$. par, Walk.

$\dagger C f$. Surcouf and Roubaud, loc. cit. 
there can be no doubt that Tabanus brumpti, Surcouf, is a perfectly good species, distinguishable from T.ruficrus, Pal. de Beauv., by its clearer wings and more brightly coloured tibiæ, and by the fringe of hair on the hind tibiæ being ochraceous-rufous instead of black. In the male the greyish bloom on the abdomen, which is so noticeable a feature in the female, appears to be wanting. Of $T$. brumpti, the range of which extends at least from the Sierra Leone Protectorate to Uganda, the Museum possesses a male from Bo, Sierra Leone Protectorate, October, 1908 (Dr. H. E. Arbuckle, W.A.M.S.,presented by the London School of Tropical Medicine), and four females. Of the latter, one is from the Benue River, Northern Nigeria, August, 1907 ( $J$. Brand), while the other three are from a banana plantation at Kampala, Uganda, 1903 (Colonel Sir David Bruce, C.B., R.A.M.C., F.R.S.).

Tabanus obscurefumatus, Surcouf.

Bulletin du Muséum d'Histoire Naturelle, Année 1906, p. 523 (Paris, 1906).

Plate VII., Fig. 50.

Of this species, the type of which is from the San Benito River, French Congo, the Museum Collection contains a single female, from Odut, Southern Nigeria, May, 1906 (G. C. Dudgeon). Nothing is known of the habits of the species, and nothing further can be said as to its distribution.

Tabanus quadriguttatus, Ricardo.

Annals and Magazine of Natural History, Ser. 8, Vol. I., p. 270 (1908).

Plate VII., fig. 51.

Although presenting some resemblance to the following species (Tabanus marmoratus, Surcouf, Plate VII., fig. 52) in general appear- 
ance, T. quadriguttatus can be distinguished without difficulty by its less sharply defined wing-markings, and especially by the absence of a dark brown transverse band running across the proximal extremity of the discal cell. T.quadriguttatus is at present represented in the National Collection by a single female (the type of the species) from Nguele, Usambara (south-east shore of Lake Victoria), German East Africa (received from Dr. Kröber). According to Surcouf and Roubaud, this species also occurs in French Congo, where it is "very common at Brazzaville at the commencement of the wet season, bites cattle, and even enters houses." *

Tabanus marmoratus, Surcouf.

(The description of this species has not yet been published, 5, VII., 1909.)

\section{Plate VII., Fig. 52.}

The figure of this West African species, which was prepared from the type, $\uparrow$ the only specimen available when the drawing was made, is unfortunately a good deal too red as regards the anterior portion of the body. The examination of a well-preserved female of $T$. marmoratus recently received shows that the actual colour of the dorsum of the thorax is slate-grey, and that of the hair on the posterior angles white; as regards the abdomen, the first segment is grey, with whitish hairs on the hind border, the second clovebrown, with a deeper posterior border of whitish hairs; the remainder is black, with median triangles clothed with silvery hair on the hind margins of the third, fourth, and fifth segments (the triangle on the fourth segment being the largest), and a narrow band of similar hair on the hind margin of the fourth segment.

The solitary specimen of $T$. marmoratus in the Museum is a female from Obuasi, Ashanti, May 27th, 1907, "caught in house" (Dr. W. M. Graham, W.A.M.S.).

* Cf. Surcouf and Roubaud, Bulletin du Muséum National d'Histoire Naturelle, Année 1908, No. 5 (Paris, 1908).

$\dagger$ Kindly lent by the authorities of the Muséum National d'Histoire Naturelle, Paris. 
Tabanus billingtoni, Newstead.

Annals of Tropical Medicine and Parasitology, Series T. M., Vol. I., No. I., p. 46, Pl. III., fig. 1, and Pl. IV., figs. 10-12 (1907).

Plate VII., FIG. 53.

Although almost identical as regards the pattern of the wingmarkings, the present species can easily be distinguished from the foregoing by the abdominal characters, including the yellow base, narrow yellow bands, and absence of median dorsal triangles. Described from specimens collected in the Congo Free State, during the expedition of the Liverpool School of Tropical Medicine to the Congo, 1903-05, the only other country from which Tabanus billingtoni has yet been received is Southern Nigeria. The localities, etc., of the eight females in the National Collection are as follows.Congo Free State: Bolengi, Upper Congo, July, 1903 (Dr. E. A. Layton); Baptist Missionary Station, Tshumbiri, near Leopoldville, 1904 (Rev. and Mrs. Billington); Lopori River, Upper Congo, October, 1907 (Rev. W. D. Armstrong). Southern Nigeria : Ologbo, May, 1906 (G. C. Dudgeon).

\section{Tabanus secedens, Walker.}

List of the Specimens of Dipterous Insects in the Collection of the British Museum, Part V., Supplement I., p. 224 (1854), -for

Tabanus tibialis, Walker (nec Macquart), op. cit., Part I., p. 162 (1848) (nomen bis lectum).

Plate VII., hig. 54.

This species, of which Tabanus gabonensis (garonensis), Macq., is a synonym, ${ }^{*}$ is somewhat variable in appearance according as

* Tabanus blanchardi, Surcouf (Archives de Parasitologie, T. XI., p. 473, PI. IX., figs. 3, 4 (1907), and T. brunnescens, Ricardo (Annals and Magazine of Natural History, Ser. 8, Vol. I., p. 322 (1908)), are also synonyms of T. secedens, Walker. 
the narrow median triangles on the abdomen remain fairly distinct, or are merged in a more or less uniform, continuous stripe. Tabanus secedens is also subject to considerable variation in size, as shown by the fifty-eight females in the Museum Collection, which vary in length from $15 \mathrm{~mm}$. (wing-expanse $31 \mathrm{~mm}$.) to $21 \mathrm{~mm}$. (wingexpanse $39.5 \mathrm{~mm}$.). The species is extremely common in many parts of West Africa, and its range is known to extend from Senegal to the Congo Free State and Uganda. The following are the localities, etc., of the specimens at present in the Museum.-Sierra Leone: Moyamba, September, 1906 (J. A. G. Fido); Sierra Leone Protectorate, 1905, "caught in native hut" (Major W. H. Grattan, R.A.M.C.) ; Karina District, Sierra Leone Protectorate, OctoberNovember, 1906 (Dr. H. E. Arbuckle, W.A.M.S.). Liberia: Bafu Bay, January, 1909, and Sinu, April 20th, 1909 (Surgeon A. McCloy, R.N.). Gold Coast: exact locality unknown, 1882 (Captains Burton and Cameron); Dunkwa, September 25th, 1905 (Dr. McConnell). Ashanti : Obuasi, March 6th, 1906, "in house on window," and May 20th, 1906; "caught in carriages on Gold Coast Government Railway," June 14th, 1906, and May 23rd and September 6th, 1907, and Huni Valley, May 1st, 1908 (Dr.W.M.Graham, W.A.M.S.). Northern Nigeria: Kaduna River, near Mureji, June 22nd, 1906 (W. F. Gowers); exact locality unknown, 1907 (G. C. Dudgeon). Southern Nigeria : Lagos, 1899, 1906 (Dr. W. H.W. Strachan, C.M.G.); Cross River and Old Calabar, 1894-95 (the late Miss Mary $H$. Kingsley); Asaba, R. Niger, 1895 (the late Dr. W. H. Crosse); Forcados River, June 18th, 1904 (W. F. Gowers); Odut and Ologbo, May, 1906, and Itu, Cross River, May and June, 1908 (G. C. Dudgeon); Calabar, April, 1907 (Major F. R. W. Sampson). Congo Free State : Bolengi, Upper Congo, July, 1903 (Dr. E. A. Layton); Congo River, below Basoko, alt. 1400 feet, November, 1906 (Ruwenzori Expedition); Lopori River, Upper Congo, October, 1907 (Rev. W. D. Armstrong). Uganda: Bulamwezi, 1903, from bank of stream (Colonel Sir David Bruce, C.B., R.A.M.C., F.R.S.); south end of Lake Albert, October, 1904, and Nimule and Gondokoro, November, 1904 (Captain E. D. W. Greig, I.M.S.).

With reference to this species as observed by him in Ashanti, 
Dr. W. M. Graham has kindly supplied the following note :"Tabanus secedens is common in Ashanti, and is very frequently met with in the carriages on the Gold Coast Government Railway. Hundreds of flies bclonging to this species sometimes follow a herd of cattle on the Cape Coast road, making a loud whizzing noise like a wind, which can be heard for some distance. T. secedens also attacks man, and in the month of December, if a clearing be made by the roadside and a tent pitched, the tent will be invaded by numbers of this fly." In the Congo Free State, most of the specimens of $T$. secedens obtained by the members of the expedition of the Liverpool School of Tropical Medicine were caught on the rivers, in steamers and canoes.* The members of the French Expedition to French Congo for the Study of Sleeping Sickness met with several males of this species drinking on the ground. Writing of $T$. secedens as it occurs in French Congo, M. Roubaud says: "The females come round houses, and seek to attack cattle. This is the commonest Tabanus at Brazzaville, where it is found from the end of September until November. It is very common all along the banks of the Alima, in marshy forests, and districts in which big game occurs, where it would seem to feed especially on the buffalo. It appears to exist throughout the entire course of the Ubangi; it attacks natives in canoes." $\dagger$

Tabanus kingsleyi, Ricardo.

Annals and Magazine of Natural History, Series 8, Vol. I., p. 318 (1908).

Plate VII., Fig. 55.

Although not unlike small specimens of the foregoing species, Tabanus kingsleyi, Ricardo, may be distinguished by the greater

* Cf. Annals of Tropical Medicine and Parasitology, Series T.M., Vol. I., No. I., p. 45 (February 1, 1907), where the species is referred to as "Tabanus gabonensis, Macq."

$\dagger C f$. Surcouf and Roubaud, Bulletin du Muséum National d'Histoire Naturelle, Année 1908, p. 221 (Paris, 1908) ("Tabanus gabonensis, Macquart"). 
breadth of the light stripes on the thorax, the more sharply defined pale median stripe on the abdomen, and the presence of a distinct, tapering, pale, longitudinal streak on each side of the latter, between the median stripe and the lateral margin.

Up to the present time $T$. kingsleyi has been received only from Sierra Leone and the Sierra Leone Protectorate. The six specimens in the Museum include five females from Port Lokkoh and Port Lokkoh Creek, April and May, 1904 (Major F. Smith, D.S.O., R.A.M.C.), and one female from the vicinity of Baiwalla, Sierra Leone Protectorate, June, 1903 (Dr. H. F. Conyngham). Major Smith's note on the specimens collected by him at Port Lokkoh in April (the dry season in Sierra Leone) runs as follows:"Numerous ; no other species about ; bit me severely in my house, several hundred yards from the water."

\section{Tabanus congoiensis, Ricardo.}

Annals and Magazine of Natural History, Ser. 8, Vol. I., p. 328 (1908).

Plate VIII., Fig. 56.

Tabanus congoiensis, Ricardo, has as yet been met with only in the Congo Free State and Portuguese Congo. The localities, etc., of the seven females in the National Collection are as follows.-Congo Free State: Tumba, Cataract Region, R. Congo, November 5th, 1903 (Drs. Dutton, Todd, and Christy); Wathen, 1904 (the late Rev. W. H. Bentley). Portuguese Congo : San Salvador, between August and October, 1908 (Dr. M. Gamble).

It may be noted that Tabanus lemairei, Surcouf (Bulletin du Muséum National d'Histoire Naturelle, Année 1908, No. 2, p. 123 (Paris, 1908),- which was described from a female from the Katanga District of the Congo Free State, belonging to the Royal Belgian Natural History Museum,-is very closely allied to, if not identical with, $T$. congoiensis, Ricardo. In $T$. lemairei, however, the first joint of the antennæ is stated to be clothed with white instead of with black hair, as is the case in $T$. congoiensis. Should the 
identity be proved, by a subsequent comparison of the types, the question as to which name is to be regarded as having priority will have to be decided. The wrapper of the number of the Bulletin du Muséum National d'Histoire Naturelle containing the description of Tabanus lemairei, Surcouf, is dated "Février, 1908," but there are reasons for thinking that the part may not have been published until April, the month in which the description of $T$. congoiensis, Ricardo, appeared.

Tabanus socialis, Walker.

Insecta Saundersiana, Vol. I., Diptera, Part I., p. 45 (1850).

Plate VIII., Fig. 57.

In this species the colour of the median stripe on the abdomen is usually a very faint grey, and, at any rate in pinned and more or less denuded specimens, the stripe generally appears more uniform and less broken up into spots than might be imagined from the figure. So far as is indicated by the localities of the specimens in the Museum, the area of distribution of Tabanus socialis extends at least from the Gambia to the Congo: it may be added that, according to its label, the type of the species is from the Congo (instead of from the "Cape," as erroneously stated by Walker), but that no other specimens have yet been received from that region. The localities, etc., of the thirty-four specimens (one male and thirty-three females) of Tabanus socialis in the Museum Collection are as follows.-Gambia (precise locality unknown), 1906 (Dr. E. Hopkinson, D.S.O.). Sierra Leone : Mt. Aureol, Freetown, May and June, 1904 (Major F. Smith, D.S.O., R.A.M.C.) ; Karina District, Sierra Leone Protectorate, October-November, 1906 (Dr. H. E. Arbuckle, W.A.M.S.) ; Bonthe, Sherbro River, March, 1908, "in mangrove swamp" (Dr. Jackson-Moore, per Dr. R. M. Forde, W.A.M.S.). Liberia : (precise locality unknown), 1908; Monrovia, February 16th, 1909, " caught on board H.M.S. Mutine, 1800 yards from the beach; wind inshore, force 2 " (Surgeon A. McCloy, 
R.N.). Gold Coast: one male and one female, Sekondi, August 18th, 1906 (Dr.W.M. Graham, W.A.M.S.) ; Axim, " caught on dredge on Ancobra River, April, 1907" (received from Dr. W. M. Graham). Southern Nigeria : Lagos, 1899 (Dr.W.H.W. Strachan, C.M.G.) ; Bonny, July, 1872 (J.J. and Mrs. Monteiro); Sapele, April, 1906, and Warri, May, 1906 (G.C. Dudgeon); Old Calabar, 1895 (the late Miss Mary H. Kingsley), and April, 1907 (Major F. R. W. Sampson). "Congo" (ex Saunders Collection).

Tabanus socialis, Walk., of which T. nigrohirtus, Ricardo (Annals and Magazine of Natural History, Ser. 7, Vol. VI., p. 165 (1900)), is a synonym, may possibly be identical with $T$. testaceiventris, Macq. (1847). Macquart's description, however, is not sufficiently definite to enable a positive opinion to be formed, and the locality of his species is given by him merely as "Afrique," without any more precise indication.

Writing of this species as met with in French Congo, by the members of the French Expedition to French Congo for the Study of Sleeping Sickness, M. Roubaud says :- "Very common at Brazzaville, where it bites man. Especially numerous during the transitional period at the end of the dry season; appears sporadically during the remainder of the year. . . . Taken in numbers on the banks of the Upper Alima, rarer on the Lower Alima : a pertinacious biter of human beings."*

Tabanus fraternus, Macquart.

Mémoires de la Société Royale des Sciences, de l'Agriculture et des Arts de Lille, Année 1844, p. 159 (Lille, 1846) : Diptères Exotiques, Supplément, p. 31 (1846).

\section{Plate VIII., fig. 58.}

Tabanus fraternus, Macq. (syn. T. bipartitus, Walk., and $T$. trisignatus, Lw.), the type of which is stated to have been collected

* Cf. Surcouf and Roubaud, Bulletin du Muséum National d'Histoire Naturelle, Année 1908, No. 5 (Paris, 1908) ("Tabanus nigrohirtus. Ricardo"). 
in Kaffraria, Cape Colony, is at present represented in the Museum Collection by only eight females, the localities of which, however, are sufficient to show that the range of the species extends at least as far to the north-east as German East Africa. The following are the localities, etc., of the Museum specimens.--

"South Africa," 1854 (R. W. Plant); "South Africa" (collected by the Rev. C. Livingstone, on Dr. Livingstone's Expeditionpresented by Lord John Russell, 1863). Natal : precise locality unknown (ex Saunders Collection). Nyasaland Protectorate : Lunyina River, Henga, 3000 feet, January 29th, 1894 (Captain Richard Crawshay); Fort Johnston, January 12th, 1906 (E. L. Rhoades); precise locality unknown, 1907 (Dr. J. E. S. Old). "East Africa,"-i.e., German East Africa (collected on Captain Speke's Expedition to the Sources of the Nile-presented by Lord John Russell, 1864).

Tabanus tæniola, Palisot de Beauvois.

Insectes Recueillis en Afrique et en Amerique, dans les Royaumes d'Oware et de Benin, A Saint-Domingue et dans les ÉtatsUnis, pendant les Années 1786-1797, p. 56, Diptères, Pl. I., fig. 6 (1805-1821).

Plate VIII., FIG. 61.

Whether or not Tabanus taniola be actually common in any given locality, there can be no doubt whatever that it is the most widely distributed of all the African Tabanidæ, its range extending from Upper Egypt, the Anglo-Egyptian and French Sudan, and Senegal, at any rate to Delagoa Bay and the Transvaal, if not still further to the south. The pale median stripe on the abdomen, which in the typical form has its sides at least as regular as in the figure, is subject to great variation in width and shape, so that it is sometimes reduced almost to a mere line, and sometimes considerably expanded beyond the middle, while in other cases again (form socius, 
Walk.) it widens out on the hind margins of the second and following segments, so that its distal portion appears to be formed by a series of truncated triangles. It is not surprising that such a species should have been described under many different names, and in all probability Tabanus socius, Walk., $T$. macrops, Walk., $T$. dorsivitta, Walk. (1854 nec 1850), and T. virgatus, Austen (nomen novum for $T$. dorsivitta, Walk.-nomen bis lectum), do not exhaust the list of synonyms of $T$. taniola, Pal. de Beauv. Tabanus variatus, Walk. (see below, p. 105, Plate VIII., fig. 59), in which the modification of the median abdominal stripe into a series of triangles, with their bases resting on the hind margins of the segments, is carried still further, is perhaps also a form of $T$. toeniola, Pal. de Beauv., although for the present it is more convenient to continue to regard it as a distinct species.

In many localities Tabanus treniola would appear to be extremely abundant, and the form socius is one of the commonest "serootflies" on the White Nile; the species is represented in almost every consignment of African blood-sucking flies received at the Museum, and the National Collection already contains nearly two hundred examples of this insect. The area of distribution of the species being so extraordinarily wide, it is unnecessary to go into details with regard to these specimens, but a few general notes may be added.

In French Congo, according to Roubaud,* Tabanus toeniola is of general occurrence though local, and only a small number of individuals are found together; in the region of Lake Chad the species is known to the natives as N'gaya Illi, or Ter Azarak.* The type of Tabanus macrops, Walk., which is from Egypt, is a male, and it is interesting to observe that out of fourteen specimens recently received from the Kharga Oasis, Upper Egypt, July and September, 1907 (the late Dr. H. H. Baker), no fewer than eleven are males: with the exception of one other specimen of this sex,from Keffi, Nassarawa Province, Northern Nigeria, May 3rd, 1907 (Dr. R. F . Williams), these are the only males of $T$. toeniola that have been

* Cf. Surcouf and Roubaud, Bulletin du Muséum National d'Histoire Naturelle, Année 1908, No. 5 (Paris, 1908). 


\section{4}

received since the arrival of the type of $T$. macrops, more than sixty years ago.

Tabanus toeniola attacks both human beings and domestic animals. According to Surcouf,* a French lieutenant of Zouaves named Chapin states that its bites are fatal to camels in French Congo. In the Kharga Oasis, Upper Egypt, where it occurs from May to September, $T$. toeniola is also said to kill camels, though according to the late Dr. H. H. Baker, formerly of the Corporation of Western Egypt, Limited, the statement needs verification. Writing from Qara, Kharga Oasis, on December 5th, 1907, Dr. Baker sajd :- "With regard to the dissemination of disease by the flies [T. toniola, Pal. de Beauv.], the evidence that $I$ have been able to obtain up to the present is not very strong. Among the natives this Oasis is considered an unhealthy place for camels, and they generally attribute its unhealthiness to the flies. Although frequently visited by Bedouin caravans, no camels are bred or kept permanently in the Oasis by the natives. Bedouins who have been obliged to keep camels here for some time, owing to want of grazing ground, are said to have lost considerable numbers of them.

"The fly undoubtedly attacks camels, and whenever it bites draws a bead of blood and causes considerable irritation. Of the camels belonging to this. Corporation which have died here, only one can be said to afford any evidence that the flies were the cause of death. In this case a camel, apparently in good health, was attacked by five or six flies : on the following day it was ill, and it died the day after. A native, who was bitten at the same time while catching specimens for me, was ill for three or four days. This took place some distance from our headquarters, and I did not see the dead camel. The fly is very rarely met with at our headquarters, but camels working in parts of the Oasis where the fly is common do not seem to be any more unhealthy than those working here. In those camels whose bodies I liave examined after death, the post-mortem appearances have becn so various that $I$ do not think that the cause of death can have been the same in all cases." It is obvious that the death of the camel two days after being bitten, in the case

* Archives de Parasitologie, T. XI., p. 472 (1907). 
mentioned by Dr. Baker, if due to any form of trypanosomiasis, and if it be true that the camel was previously in good health, indicates a disease of a more acute type than ordinary nagana;* the illness of the native, who was bitten at the same time, possibly points to some septic poison having been introduced on this occasion by the bites of the flies. Nevertheless the belief in the existence of a camel-killing fly prevails in other parts of Egypt, e.g., in the Fayûm, where the Arab camel-drivers.assert that there is a fly in May and June which kills camels, $f$ and in this case also it is possible that Tabanus toeniola is the species implicated. In any event, experiments should be made with $T$. toniola in order to determine whether it possesses the power of transmitting disease. Should the species really be a disease-carrier among camels in Northern Africa, the malady disseminated is doubtless el debab (in Egypt, el debeh), which, according to Drs. Edmond and Etienne Sergent, occurs from Morocco to Syria, and more than decimates camels in Algeria.\$

Tabanus variatus, Walker.

Insecta Saundersiana, Vol. I., Diptera, Part I., p. 64 (1850).

Plate VIII., Fig. 59.

Tabanus variatus, Walk. (syn. T. rubicundus, Walk. (nec Macq.), and T. serratus, Lw.), affords another instance of wide distribution, its range extending from Cape Colony to Abyssinia, and north-west

* C\% the remarks by Nabarro and Greig (Reports of the Sleeping Sickness Commission, No. V., p. 44, (July, 1905)), on the "Jinja" disease in cattle in Uganda, "known locally as "Sutoko," from which it appears that "the cattle, often quite well, may be stricken down and die in 24 hours."

$\dagger C f$. Austen, "A Monograph of the Tsetse-Flies" (London: Printed by Order of the Trustees of the British Museum, 1903), p. 304.

$\ddagger C f$. Drs. Edmond and Étienne Sergent, "El-Debab. - Trypanosomiase des dromadaires de l'Afrique du Nord " (Annales de l'Institut Pasteur, T. XIX., pp. 17-48 (1905)).- - In Algeria, it was shown experimentally by the authors that Tabanus nemoralis, Mg., and $T$. tomentosus, Macq., are able to transmit the disease when they bite a healthy animal immediately after having bitten one that is infected. In one successful experiment with $T$. tomentosus, however, there was an interval of twentytwo hours between the bites. 
at least as far as the Gambia. The possibility that Tabanus variatus, which is represented in the Museum Collection by fortythree females, is in reality a form of Tabanus toniola, Pal. de Beauv., has already been alluded to in the notes on that species.* The localities, etc., of the Museum specimens are as follows._- "Interior of South Africa," before 1843 (presented by the Earl of Derby). Orange River Colony: Bloemfontein, 1898 (- Wilman). Nyasaland Protectorate: Blantyre District, May, 1905, and Zomba, April, $1906(D r . J . E . S$. Old $)$; Upper Shirè River, January 14th and 20th, and Nkata Bay, Lake Nyasa, April 15th, 1906 (E. L. Rhoades). German East Africa : precise locality unknown (collected on Captain Speke's Expedition to the Sources of the Nile-presented by Lord John Russell, 1864). Uganda: Ankole, May 9th, Buddu and Bulamwezi, 1903 (Colonel Sir David Bruce, C.B., R.A.M.C., F.R.S.) ; Junda, Buruli, "in banana plantation near R. Seziwa," and Buruli, "in patch of forest on Lukoge River, half-way between Junda and Kisiliza," 1903 (S. C. Tomkins); Kisembara, February 10th (Dr. Cuthbert Christy); Wadelai, November, 1904 (Captain E. D. W. Greig, I.M.S.); Albert Lake District, 1905 (Dr. G. H. Pooley); Northern Usoga, 1906 (received from Dr. A. D. P. Hodges). Abyssinia: Dembratcha, Godjam, April-May, 1902 (E. Degen). Angola: Bihé and Benguella, 1904 (Dr. F. Creighton Wellman). Northern Nigeria : Loko, north bank of Benue River, March, 1907 (Dr. B. McGahey, W.A.M.S.). Gambia, 1906 (Dr. E. Hopkinson, D.S.O.).

This species also occurs on the islands in the Gulf of Guinea. According to R. Greeff, $\uparrow$ “T. serratus, Lw." (i.e. T. variatus, Walk.), is very widely distributed upon St. Thomas I., but rare on Rolas : it is said to attack human beings, especially natives, with peculiar pertinacity.

It may be noted that Tabanus variatus, Walk., perhaps $=T$. sagittarius, Macq., but that without making an examination of Macquart's type a definite decision as to this is impossible.

* See above, p. 103.

†Cf. R. Greeff, Sitzgsber. der Gesellsch. zur. Bef. der ges. Naturwissensch. zu Marburg, 1884, p. 78. 
Tabanus nigrostriatus, Ricardo.

Annals and Magazine of Natural History, Ser. 8, Vol. I., p. 317 (1908).

Plate VIII., Fig. 60.

This well-marked and easily recognisable species, which has hitherto been received only from the Nyasaland Protectorate, is represented in the National Collection by seven females from the Plateau of Zomba, presented in 1897 by Sir Alfred Sharpe, K.C.M.G., C.B.

Tabanus conspicuus, Ricardo.

Annals and Magazine of Natural History, Ser. 8, Vol. I., p. 313 (1908).

Plate VIII., FIg. 62.

The only specimens of this species yet received are three females from Yoiuti, East Africa Protectorate, about twenty miles from the mouth of the Juba River (Major L. H. R. Pope-Hennessy, D.S.O.). The flies are stated by the donor to have flown into the cabin of a steam-launch, in February, 1905.

Tabanus liventipes, Surcouf.

Bulletin du Muséum d'Histoire Naturelle, Année 1907, p. 38 (Paris, 1907).

Plate VIII., Fig. 63.

The figure of this species, which is not yet represented in the British Museum (Natural History), has been prepared from the type, kindly lent for the purpose by the authorities of the Muséum d'Histoire Naturelle, Paris, which possesses two females taken on 
the coast of Mozambique, Portuguese East Africa, in 1906, by M. G. Vasse. Up to the present time, the species has not been recorded from any other locality.

Tabanus denshamii, Austen.

Annals and Magazine of Natural History, Ser. 8, Vol. I., p. 222 (1908).

Plate IX., fig. 64.

This exceedingly striking species, which has hitherto been met with only in Uganda, North-Eastern Rhodesia, and the Katanga District, Congo Free State, is represented in the National Collection by four females, three of which are from Unyoro, Uganda, half-way between Masindi and the Murchison Falls, January, 1907 (the late Dr. W. A. Densham), while the fourth is from Fwambo, near the south-east end of Lake Tanganyika, North-Eastern Rhodesia, 1896 (W. H. Nutt). The late Dr. Densham in whose honour the species was named, supplied the following field-note concerning Tabanus denshamii, as met with by him in Uganda:- "I saw this fly for the first time in January, 1907, half-way between Masindi and the Murchison Falls. In its flight and manner of alighting it resembles Tabanus toeniola, Pal. de Beauv., and I overlooked the first that appeared. I found it in several camps in the neighbourhood, but its distribution seems very local. The natives say that it is an elephant fly, but I shot an elephant in the vicinity, and saw no biting flies at all on or near it."

Tabanus ustus, Walker.

The Zoologist, Vol. VIII., Appendix p. xev. (1850).

Plate IX., Fia. 65.

There can be little doubt that Tabanus ustus, Walk., of which Tabanus temperatus, Walk., is a synonym, is the species referred to 
by Loew ("Dipteren-Fauna Südafrika's" (1860), p. 38) as Tabanus bovinus; but although Tabanus ustus, Walk., may well be the local representative of the European T. bovinus, Loew, there are reasons - such as the very conspicuous, grey, admedian, abdominal spots, and the absence of pale hind margins to the abdominal segmentsfor thinking that it is preferable to regard Tabanus ustus as a distinct species. It may be noted that the type of Tabanus ustus, Walk., is a male, and that of T. temperatus, Walk., a female.

Up to the present time Tabanus ustus has been found in Cape Colony, Natal, and North-Eastern Rhodesia; but if, as seems possible, Tabanus disjunctus, Ricardo (Annals and Magazine of Natural History, Ser. 8, Vol. I., p. 325 (1908)) is but a form of $T$. ustus, Walk., the range of the species will also include North-Western Rhodesia, the Congo Free State, and Uganda.

The localities, etc., of the thirteen specimens of Tabanus ustus, Walk., in the Museum are as follows.-Natal. "Port Natal" (types of T. ustus, Walk., and T. temperatus, Walk., and one specimen collected by Gueinzius, before 1858); precise locality unknown (received from J. F. Quekett, 1902). Kosi Bay, Zululand, February and March, 1906, "on cattle" (F. Toppin). North-Eastern Rhodesia : Muebe and Upper Lukula River, Luena District, September 4th and 29th, 1904, "a plague in places" (R. L. Harger).

Tabanus nyasæ, Ricardo.

Annals and Magazine of Natural History, Ser. 7, Vol. VI., p. 164 (1900).

Plate IX., Fig. 66.

This species, which was described from a female from Fort Johnston, Nyasaland Protectorate, in the collection of Mr. W. L. Distant, is represented in the Museum Collection by a single female, from Salisbury, Mashonaland, Southern Rhodesia, October 12th, 1900 (R. H. Thomas). Tabanus nyasce, Ricardo, of which $T$. 
tarsalis, Adams (Kans. Univ. Sc. Bull., Vol. III., (XIII.), p. 151 (1905) ), is a synonym, is allied to $T$. denshamii, Austen (Plate IX., fig. 64), but is distinguished by the much larger lateral abdominal spots, the paler wings, in which the veins are less deeply suffused with brown, and other characters.

Tabanus æneus, Surcouf.

Bulletin du Muséum National d'Histoire Naturelle, Année 1907, p. 265 (Paris, 1907).

Plate IX., fig. 67.

No specimen of this striking species has yet been received by the British Museum (Natural History). Through the courtesy of M. J. R. M. Surcouf, of the Muséum National d'Histoire Naturelle, Paris, the figure has been prepared from the type, which forms part of the collection of the Naturhistorisches Museum, Hamburg, and was taken at Mukonje Farm, near Mundame, Mungo River, Cameroon, December 20th, 1905 (Herr R. Rohde).

Tabanus canus, Karsch.

Zeitschrift für die gesammten Naturwissenschaften, Bd. LII., p. 377 (1879).

Plate IX., Fig. 68.

This easily recognisable species, of which Tabanus multipunctatus, v.d. Wulp, is a synonym, was described from a specimen from Cabinda, Portuguese West Africa. The localities, etc., of the seven females in the Museum Collection, which with one exception are all from the Congo Free State, are as follows.-Congo Free State: Lutete, November 4th, 1903, and Leopoldville, February 18th, 1904 (Drs. Dutton, Todd, and Christy); Bolengi, Upper Congo, July, 1903 
(Dr. E. A. Layton); Bonginda, Lulanga River, Upper Congo, November 5th, 1907 (Rev. W. D. Armstrong). Portuguese Congo: San Salvador, 1909 (Dr. M. Gamble).

Dr. J. L. Todd, writing of Tabanus canus as met with in the Congo Free State during the Expedition of the Liverpool School of Tropical Medicine to the Congo, 1903-05, remarks:- "This fly was only taken by persons travelling in canoes. It is reported to fly very rapidly, and its bite is said to be very severe." * According to the Rev. W. D. Armstrong, in the Congo Free State the species is "never found inland, is not very numerous, and only comes out in the twilight." The latter statement is supported by the mention by Surcouf and Roubaud of three specimens of $T$. canus as having been taken at 6.0 p.m. on the Lower Alima, in French Congo, where it is stated to attack human beings. $\dagger$

Tabanus quadrisignatus, Ricardo.

Annals and Magazine of Natural History, Ser. 8, Vol. I., p. 320 (1908).

Plate IX., Fig. 69.

Three females, from Ruwe, Lualaba River, and the valley of the Lualaba, Katanga District, Congo Free State (between $9^{\circ}$ and $11^{\circ}$ S., and about $26^{\circ}$ E.), February, 1906 (Dr. A. Yale Massey), are the present representatives of this species in the National Collection. Tabanus distinctus, Ricardo, which occurs in North-Eastern Rhodesia and Benguella, Angola, may be distinguished from $T$. quadrisignatus, which it closely resembles as regards the abdominal markings, by the presence of a narrow median light stripe on the front portion of the thorax.

* Annals of Tropical Medicine and Parasitology, Series T.M., Vol. I., No. I., p. 44 (February 1, 1907).

$† C f$. Surcouf and Roubaud, Bulletin du Muséum National d'Histoire Naturelle, Année 1908, No. 5 (Paris, 1908). 
Tabanus subangustus, Ricardo.

Annals and Magazine of Natural History, Ser. 8, Vol. I., p. 314 (1908).

Plate IX., Fig. 70.

Up to the present time this species has been received by the British Museum (Natural History) only from Northern and Southern Nigeria, although according to Miss Ricardo, the Muséum National d'Histoire Naturelle, Paris, possesses specimens of it from Senegambia. The localities, etc., of the nine females of $T$. subangustus in the National Collection are as follows.-Northern Nigeria: Zungeru, June 27th, and July 4th and 7th, 1905 (Dr. Dalziel); Shonga, June, 1907 (G. C. Dudgeon) ; Zaria, July 15th, 1907 (J. Brand); Amara, R. Benue, July and August, 1907 (Dr. J. McF. Pollard, W.A.M.S.). Southern Nigeria: Abutshi, R. Niger, 1903 (A. Braham); Odut, May, 1906 (G. C. Dudgeon).

Tabanus albilinea, Walker.

List of the Specimens of Dipterous Insects in the Collection of the British Museum, Part I., p. 176 (1848).

Plate IX., Fig. 71.

Tabanus albilinea, Walk., is a South African species, which is at present represented in the Museum Collection by four females. Two of these specimens (including the type) are without localities; the other two are from Cape Town, 1864 (R. Trimen), and Pirie Bush, Cape Colony, 1898 ( $A$. N. Stenning), respectively.

Tabanus diversus, Ricardo.

Annals and Magazine of Natural History, Ser. 8, Vol. I., p. 330 (1908).

Plate X., Fig. 72.

The only specimens of this pretty little species yet received are 
two females from Ruwe, Lualaba River, Katanga District, Congo Free State, about $11^{\circ} \mathrm{S}$. and $26^{\circ}$ E., February, 1906 (Dr. A. Yale Massey), one of which is the type of the species. Tabanus diversus, Ricardo, resembles $T$. insignis, Lw. (found in Cape Colony, Natal, and Uganda-see page 72 and Plate V., fig. 35), but may be distinguished by its smaller size, and by the absence of a group of four grey spots in the centre of the second abdominal segment.

\section{Tabanus sharpei, Austen.}

Annals and Magazine of Natural History, Ser. 8, Vol. I., p. 226 (1908).

\section{Plate X., fig. 73.}

The figure of this species has been prepared from the type, the only specimen hitherto received, which is from Katumbe, North Nyasa, Nyasaland Protectorate, December 6th, 1906 (Dr. J. E. S. Old). The collector's field-note with reference to this specimen is as follows :- "Country swampy jungle, with very tall, coarse reeds, and forest with low trees. Only game seen were bushbuck, waterbuck and wart-hog; old eland spoor plentiful, and that of buffalo some months old."

Tabanus wellmanii, Austen.

Annals and Magazine of Natural History, Ser. 8, Vol. I., p. 225 (1908).

$$
\text { Plate X., FIG. } 74 .
$$

Of this species the Museum possesses the type and five other females, all collected in the Chiyaka District, Angola, in March, 1906, by Dr. F. Creighton Wellman, who states that the flies were "taken in a thick jungle," and that the species is "a pertinacious biter." From Tabanus argenteus, Surcouf,* T. wellmanii may be 
distinguished, inter alia, by the presence of a pair of pearl-grey stripes on the anterior portion of the thorax, and by the shape of the abdominal spots.

Tabanus argenteus, Surcouf.

Bulletin du Muséum National d'Histoire Naturelle, Année 1907, p. 264 (Paris, 1907).

Plate X., Fig. 75.

The type of this species, which belongs to the Naturhistorisches Museum, Hamburg, is from the Gaboon, French Congo, where it was collected in 1881 by $M$. Soyaux. According to Surcouf and Roubaud,* this species seems not to occur at Brazzaville, French Congo, although (during the French Expedition to French Congo for the Study of Sleeping Sickness) three females were received from the district called Boula N'tangou, on the plateaus about one hundred kilometres to the west of Brazzaville : they were collected during the transitional period at the end of the wet season. For the opportunity of figuring Tabanus argenteus, which is not yet represented in the British Museum (Natural History), acknowledgment is due to M. J. R. M. Surcouf, of the Muséum National d'Histoire Naturelle, Paris.

Tabanus gratus, Loew.

Öfvers. af Kongl. Vetensk._Akad. Förhandl., XIV., 1857, p. 340 (1858) : Dipteren-Fauna Südafrika's, p. 42 (1860).

Plate X., Fig. 76.

The range of this species, which was originally described from a specimen from Kaffraria, Cape Colony, is now known to extend to the north-east and north as far as Somaliland, the Anglo-Egyptian

* Bulletin du Muséum National d'Histoire Naturelle, Année 1908, No. 5 (Paris, 1908) ("Tabanus argentatus"). 
Sudan, and Egypt, and north-westwards to Upper Senegal and the Gambia. The localities, etc., of the ten females in the Museum Collection are as follows.-Nyasaland Protectorate: Chirua River, "in the hills," May 5th, 1909 (Dr. E. H. A. Pask). Uganda: Fajao, Victoria Nile, November, 1904 (Captain E. D. W. Greig, I.M.S.); Nimule, Nile Province, 1906 (the late $D r . W . A$. Densham). Northern Nigeria: near Yola, April 14th, 1905 (W. F. Gowers); Kontagora, January 28th, Ruka, July 17th, and Benue River, August, 1907 (J. Brand). French Sudan: locality unknown (received from M. J. R. M. Surcouf). According to Todd and Newstead,* Tabanus gratus, Lw., was met with in March, 1903, "on the Kunchau Creek, about 175 miles up the Gambia River," by the Expedition of the Liverpool School of Tropical Medicine to Senegambia.

In his field-note on this species, as encountered by him in the Nile Province of Uganda, the late Dr. Densham wrote :- "Seen several times at and near Nimule : taken on natives and on a dog. Eyes in living insect a beautiful greenish blue, with horizontal zigzag bands of crimson-purple." In French Congo, Tabanus gratus is stated by Surcouf and Roubaud to be common on cattle at Brazzaville at the beginning of the rains. $\dagger$

Tabanus laverani, Surcouf.

Bulletin du Muséum National d'Histoire Naturelle, Année 1907, p. 331 (Paris, 1907).

Plate X., Fig. 77.

So far as is indicated by the specimens already received, the range of this West African species extends from the Gambia to Northern Nigeria. The following are the localities, etc., of the ten females in the National Collection.-Gambia, precise locality unknown, 1906 (Dr. E. Hopkinson, D.S.O.). French Guinea: Lower Rio

* Cf. Newstead, Dutton and Todd, Annals of Tropical Medicine and Parasitology, Series T.M., Vol. I., No. I., p. 45 (February 1, 1907).

$\dagger C f$. Surcouf and Roubaud, Bulletin du Muséum National d'Histoire Naturelle, Année 1908, No. 5 (Paris, 1908). 
116

Nunez, 1904 (received from M. J. R. M. Surcouf). Sierra Leone : near Songotown, April, 1904 (Major F. Smith, D.S.O., R.A.M.C.) ; Batkanu, Sierra Leone Protectorate, May, 1907, "caught inside house, about 150 yards from river" (Dr. H. E. Arbuckle, W.A.M.S.). Northern Nigeria: Gwagwa, Nassarawa Province, May 12th, 1907, "on horse" (Dr. R. F. Williams, W.A.M.S.) ; Kontagora, June, 1907 (G. C. Dudgeon).

Tabanus variabilis, Loew.

Öfvers. af Kongl. Vetensk.-Akad. Förhandl., XIV., 1857, p. 340 (1858) : Dipteren-Fauna Südafrika's, p. 41, Taf. I., fig. 23 (1860).

\section{Plate X.; fig. 78.}

This species, which was originally described from Cape Colony, has recently been received from Uganda and the Katanga District of the Congo Free State. The following are the localities, etc., of the nineteen females in the Museum.-Uganda: Junda, Buruli, "in banana plantation near River Seziwa," 1903 (S. C. Tomkins); Busoga, March, 1906 (Dr. A. D. P. Hodges), and August 7th, 1903 (Colonel Sir David Bruce, C.B., R.A.M.C., F.R.S.) ; Northern Usoga and north-east side of Lake George, 1906 (received from Dr. A. D. P. Hodges). Congo Free State: Ruwe, Lualaba River, about $11^{\circ} \mathrm{S}$, and $26^{\circ}$ E., February, 1906, and near Lualaba River, Katanga District, between $9^{\circ}$ and $10^{\circ}$ S., January, 1907 (Dr. A. Yale Massey).

Tabanus rothschildi, Surcouf.

Bulletin du Muséum d'Histoire Naturelle, Année 1906, p. 527 (Paris, 1906).

\section{Plate X., FIG. 79.}

The only specimens of this species yet obtained are the type and two other females, which are now in the collection of the Muséum 
National d'Histoire Naturelle, Paris, and were taken at Voi, in the East Africa Protectorate, in 1906, by M. Maurice de Rothschild: the figure has been prepared from one of these females, kindly lent for the purpose by M. Surcouf.

In markings and general appearance Tabanus rothschildi, Surcouf, closely resembles T. morsitans, Ricardo, a Somaliland species extremely common on the Webi Shebeli, which in Ogaden is known as "Balaad" and is believed to disseminate a disease which is fatal to horses, mules, and camels.* The two species can, however, be distinguished, inter alia, by the frontal callus, which in $T$. morsitans is very large (about two-thirds as deep as broad), prominent, and shining clove-brown, with its upper margin convex, while in $T$. rothschildi, the callus is mummy-brown instead of clove-brown, less than half as deep as broad, and its upper margin is concave.

Tabanus tæniatus; Macquart.

Histoire Naturelle des Insectes, Diptères, T. I., p. 207 (1834).

Plate XI., Fig. 80.

Tabanus tceniatus, Macq., which was described from a female from Cape Colony, also occurs in the Transvaal, but no specimens have as yet been received from elsewhere. The localities, etc., of the four examples in the Museum are as follows.- "South Africa," before 1844 (Dr. Andrew Smith). Simon's Town, Cape Colony, February, 1893 (P. de la Garde, R.N.). Piet Retief, Transvaal, October 25th (male) and November 1st (female), 1903 (Captain Richard Crawshay). The female caught by Captain Crawshay was taken on his stocking, which it was endeavouring to pierce with its proboscis.

This and the following species (Tabanus ruwenzorii, RicardoPlate XI., fig. 81), as well as Tabanus capensis, Wied., and $T$. tenuicornis, Macq. (syn. T. stigma, Walk.-nec Fabr.), all of which have hairy eyes, belong to the subgenus Therioplectes, Zeller.

* Letter from Dr. R. E. Drake-Brockman to Mr. C. E. Fagan, dated May 20th, 1905 : cf. also Austen, "Monograph of the Tsetse-Flies" (1903), p. 307. 
Tabanus ruwenzorii, Ricardo.

Annals and Magazine of Natural History, Ser. 8, Vol. I., p. 332 (1908).

Plate XI., Fig. 81.

Among the new species obtained by the recent Ruwenzori Expedition, were two females (including the type) of Tabanus ruwenzorii, Ricardo, from Mubuku Valley, East Ruwenzori, Uganda, between 5000 and 13,000 feet, taken on January 22nd and February 2nd, 1906, by the Hon. Gerald Legge and Mr. A. F. R. Wollaston. Up to the present time $T$. ruwenzorii has not been received from any other locality.

Tabanus ditæniatus, Macquart.

Mémoires de la Société Royale des Sciences, de l'Agriculture et des Arts de Lille, $2^{\mathrm{e}}$ partie, p. 130 (1838): Diptères Exotiques, T. I., I ${ }^{\text {re }}$ partie, p. 126 (1838).

\section{Plate XI., Fig. 82.}

This species, which was described from Mauritius and also occurs in Réunion Island, has an extraordinarily wide distribution. While in Africa itself its range extends at least from the Transvaal to Egypt, and north-westwards to the Lake Chad region, and Senegal, Tabanus ditceniatus is also found in Baluchistan, India, Ceylon, China,* and Japan. The following are the localities, etc., of the thirty-six African specimens in the Museum Collection. -Transvaal : Pretoria, 1893 (W. L. Distant); Leydsdorp, May, 1907 (Dr. A. Copland). Portuguese East Africa : Marracune and Incanine, Lorenzo Marques, February 10th and 12th, 1907 (F.D. McMillan). Nyasaland Protectorate: Fort Johnston (Dr. Percy Rendall); Upper Shirè, January 20th, Fort Johnston, January

* A number of specimens of $T$. ditceniatus, caught attacking horses and cattle, were forwarded from Wei-Hai-Wei in 1907, by $D r$. W. M. Muat. 
25th, 1906 (E. L. Rhoades); Chikala District, March 29th, and Zomba, April, 1906 (Dr. J. E. S. Old). East Africa Protectorate: Mbuyuni, 1897 (C. S. Betton); Warkoi, 30 miles from the mouth of the R. Juba, March, 1905 (Major L.H.R. Pope-Hennessy, D.S.O.); Malka Sala, Dawa River, December 15th, 1908 (Dr. R. E. DrakeBrockman). West Somaliland: Odhun and Gebidi labba dehd, River Webi, November 26th and 27th, 1908 (Dr. R. E. DrakeBrockman). Anglo-Egyptian Sudan: Bahr-El-Ghazal, February, 1905 (Lieut-Colonel R. H. Penton, D.S.O., R.A.M.C.). Angola: exact locality unknown, $1873(J . J$. Monteiro). Northern Nigeria : Hadeija, March 8th and 28th, and Katagum, August 19th, 1907 (Dr. J. M. Dalziel); R. Benue, between Amara and Ibi, 1908 (Dr. J. McF. Pollard). Gold Coast: Accra, November 6th, 1907 (Dr. W. M. Graham, W.A.M.S.). A specimen of T. ditoeniatus, Macq., was "caught in a European house placed on high ground at the mouth of the Gambia River," during the Expedition of the Liverpool School of Tropical Medicine to Senegambia, 1902-1903.*

It is stated by Surcouf and Roubaud $\dagger$ that in the region of Lake Chad Tabanus ditceniatus is known to the natives as Ter Abbiot (white-headed Tabanus). Dr. J. E. S. Old, in an official report on blood-sucking flies met with by him in the Chikala District, Nyasaland Protectorate, in March, 1906, writes of Tabanus ditoeniatus :"Some were seen on the plastering of the outside walls of the huts of Chibwano's village, and biting men underneath Ficus trees." According to Major L. H. R. Pope-Hennessy (in litt., March 19th, 1905), the Somalis near Kismayu, Jubaland, East Africa Protectorate, call this species "Baal ad," or "Baal att," but it would appear that the name is applied indiscriminately to any small Tabanid. $f$

* Cf. Newstead, Dutton and Todd, Annals of Tropical Medicine and Parasitology, Series T.M., Vol. I., No. I., p. 44 (February 1, 1907), where the species is called Atylotus nigromaculatus, Ric.

† Bulletin du Muséum National d'Histoire Naturelle, Année 1908, No. 5 (Paris, 1908).

$\ddagger$ Vide supra, pp. 63 and 117, and also Austen, "A Monograph of the Tsetseflies" (1907), p. 307 and note.-Dr. R. E. Drake-Brockman writes that $T$. ditoniatus is " well known to the Somalis by the name of 'Bal ad,' and is considered by them to be dangerous to stock, camels in particular suffering greatly from their onslaughts. Although human beings are frequently attacked by these flies, no ill-effects seem to accrue." 
The following note on T. ditceniatus in Lorenzo Marques is supplied by Mr. F. D. McMillan :- "Native name Wame Bowu. This very noisy fly is found on footpaths, follows one for miles, and always bites low down on the leg, round the ankles: I have met with it only in the heat of the day. A slight stinging feeling is left after the bite. Next day there appears a small, hard lump, which itches very much, and often ends in an abscess or boil."

Tabanus ditceniatus, Macq., of which T. bipunctatus, v.d. Wulp, and Atylotus nigromaculatus, Ricardo, are synonyms, with the closely allied Tabanus fuscipes, Ricardo (of Natal, Southern Rhodesia, and the Nyasaland Protectorate), and certain other species such as $T$. agrestis, Wied., and $T$. agricola, Wied., belongs to the subgenus Atylotus, Osten Sacken.

Tabanus claritibialis, Ricardo.

Annals and Magazine of Natural History, Ser. 8, Vol. I., p. 276 (1908).

Plate XI., fig. 83.

The type and one other female, both from the Upper Shirè River, Nyasaland Protectorate, January 14th and 21st, 1906 (E. L. Rhoades), are the only specimens of this prettily marked and easily recognisable species that have yet been received.

\section{Genus HÆMATOPOTA,* Meigen.}

Illiger's Magazin für Insektenkunde, Bd. II., p. 267 (1803).

Plate XI., Fig. 84-Plate XII., Fig. 94.

Africa is peculiarly rich in species belonging to this bloodthirsty

* By Dr. Kertész ("Catalogus Dipterorum Hucusque Descriptorum," Vol. III., p. 201: Budapestini, 1908) and other continental Dipterists the name Chrysozona, Meigen ("Nouvelle Classification des Mouches à Deux Ailes (Diptera L.)," p. 23, 34, $1800)$, has recently been adopted as the designation of this well-known genus. Within the last few months cogent arguments against the acceptance of this 
genus, which, with the possible exception of the South American and Australian Regions, whence no species have yet been described, is universally distributed. While at the present time the total number of recognised non-Ethiopian species of Homatopota only amounts to thirty-four, no fewer than seventy-nine* species have been described from Africa alone, and the Museum Collection possesses examples of more than one new species awaiting description. The peculiar wing-markings characteristic of Homatopota,-coupled with the elongate antennæ and the fact that the wings when at rest meet together at the base and then diverge slightly, sloping somewhat like the roof of a house,--render it easy to recognise a species as belonging to the genus; but the distinction of the species themselves is by no means so easy, and is often a matter of great difficulty. In all species of Hcematopota the wings are more or less infuscated, and the dark ground-colour is interrupted by pale markings, which, though for the most part sinuous or broken up into spots, usually include three "rosettes," or at least the vestiges thereof. These rosettes, though their boundaries may be somewhat blurred and indistinct, always occupy the same relative positions, and will be found surrounding the distal extremities of the basal and discal cells, and the fork of the third longitudinal vein $\dagger$ (compare figs. 87, Plate XI., and 91, 92, and 93,

emendation have been advanced by Mr. G. H. Verrall ("British Flies," Vol. V., p. 772.-London: Gurney \& Jackson, 10, Paternoster Row, January 1st, 1909), who refuses to admit any claim to validity and priority on behalf of the genera described in Meigen's paper of 1800. Apart, however, from Mr. Verrall's contentions, the description of Chrysozona, as reproduced by Hendel (Verh. z.-b. Ges. Wien, 1908, pp. 52-53) cannot honestly be considered recognisable, since the statement as to the resting position of the wings is misleading, nothing is said as to the characteristic wing-markings, and no type-species is mentioned. Nioreover, even assuming Chrysozona to possess unimpeachable claims to validity and priority, the fact remains that the name was, so to speak, stillborn-i.e., never entered into common use, and for more than a century has been buried in oblivion. For every reason, therefore, to resuscitate the name Chrysozona at the expense of Hcematopota is a step as unwarranted as it is retrogressive.

* Eighty species, if Parhomatopota cognata, Grünb., be included; as stated above (p. 66), it is doubtful whether Parhomatopota, Grünb., is really distinct from Homatopota.

$\dagger$ The discal cell in the wing of a Tabanid is the clearly defined elongate hexagonal enclosure situate about the middle; the basal cells are the two elongate cells between the discal cell and the base of the wing; the third longitudinal vein is the vein above the discal cell, connected with the upper boundary of the latter by a short cross-vein (the small transverse vein), and bifurcate about the commencement of the apical fourth of the wing. These details are clearly shown in the figures. 
Plate XII.). Occasionally the borders of the rosettes are compound, as in Hocmatopota coronata, Austen (Plate XII., fig. 91), while in H. ugandae, Ricardo (Plate XII., fig. 93), the centres of the rosettes are usually filled out with a different shade of colour : in species such as $H$. fulva, Austen, and $H$. denshamii, Austen (Plate XI., figs. 84, 85), in which the dark colour in the wing is for the most part confined to the apex and hind border, remains of at least the distal rosette are generally distinguishable, while faint traces of one or both of the other rosettes can often be seen. Other useful characters for the distinction of species presented by the wings are to be found in the markings of the discal cell and of the wing-tip, the nature of the stigma (the more or less dark, elongate and somewhat thickened spot below the end of the first longitudinal vein), and the presence or absence of a large, unbroken, dark blotch beneath it. The markings on the front and hind tibiæ (if present) should also be noted, while additional characters are afforded by the shape of these joints (whether swollen or non-swollen), by that of those of the antennæ, ${ }^{*}$ and by the shape and coloration of the frontal callus (the raised and shining area on the head between the eyes, above the base of the antennæ).

The majority of species of Homatopota are somewhat sombrely coloured flies, since, in addition to the dusky hue of the wings, the coloration of the usually narrow, elongate body is generally some shade of brown or grey, often relieved with markings, such as longitudinal stripes on the thorax or a double row of spots on the abdomen (sometimes with the addition of an edging to the abdominal segments and a series of median dorsal triangles), in a lighter shade of grey. The eyes in the living insects are usually shining coppery

* The shape of the first and third joints of the antennæ varies greatly in different species of Hcematopota, for which reason it is doubtful whether Parhamatopota, Grünb. (founded, as already stated, on these characters for $P$. cognata, Grünb.German East Africa and Zanzibar), can be maintained. Should Parhamatopota, Grünb., be recognised as a valid genus, Hamatopota brunnescens, Ricardo (Uganda and Nyasaland Protectorate), would also have to be assigned to it. Speiser is, however, mistaken in stating (Zeitschrift fïr syst. Hymenopterologie $u$. Dipterologie, VII. Jahrg., 1907. p. 360), that $H$. vittata, Lw., is a Parhæematopota, since in this species, as also in the closely allied H. pulchrithorax, Austen, and others, the first joint of the antennæ is elongate cylindrical, and its upper angle is not produced, although there is a notch on the upper side just before the tip. 
green or bluish green, with the upper and lower margins and three horizontal and partly zigzag bands dark brown.

Although extremely bloodthirsty and pertinacious in their attacks, and when numerous making their presence severely felt both by human beings and domestic animals, the females of most species of Homatopota are sluggish flies, which are easily caught with the fingers when biting. In West Africa several species are met with in shady bush-paths, where they often attack travellers in hammocks. In Angola, according to Dr. Creighton Wellman :"These flies are a terrible pest in the wet season, both to men and animals." "The nearly naked natives," continues Dr. Wellman, "suffer badly, and I have seen even a phlegmatic donkey become excited over them. One sometimes sees a horse or mule with the side of its neck almost literally covered with the tormentors. They will bite through thin clothing."* The author is informed by Mr. E. A. Copeman (late District Commissioner, British South Africa Company) that in the Kasempa District, North-Western Rhodesia, Homatopota copemanii, Austen, H. pertinens, Austen, and at least two other species of the genus are " an awful pest in the early rainy season"; Mr. Copeman adds that the bites cause "irritation and swelling."

So far as can be ascertained, the only observations

Life-history. that have yet been made on the preliminary stages of any species of Homatopota refer to the common Palæarctic $H$. pluvialis, Linn.; even of this the egg-stage has not been observed, but the larva and pupa are of the ordinary Tabanid type. The larva,-which is carnivorous, and has been known to bore its way into a beetle-larva, only leaving the latter on becoming too large for its host to contain it,-resembles that of a Tabanus; the usual transverse row of fleshy protuberances on each of the first seven abdominal segments is composed of two pairs on the actual ventral surface, and a single protuberance occupying a more lateral position on each side of these; the longitudinal striations on the body are exceedingly fine. Beling on several

*Cf. F. Creighton Wellmann, M.D., Entomological News, Vol. XIX., No. 5, pp. 228-229 (May, 1908). 
occasions found the larva singly in humus, and in one instance in a heap of pig's-dung at the edge of a meadow ; * Lundbeck thinks that the larva lives in water or damp earth, and he has received pupæ taken in the soil of moors and in moist sand near the margin of lakes.t The pupa, according to this author, closely resembles that of Chrysops, and has six spines on the terminal segment.

The experimental evidence as to the transmission Hæmatopota or otherwise of pathogenic organisms by species and Disease. of Hamatopota is at present so slight as to be scarcely worth mentioning. In Algeria, in 1905, an attempt by Drs. Edmond and Etienne Sergent to transmit the trypanosome of a disease of horses termed by them mal de la Zousfana, by injecting into the peritoneum of a white rat an emulsion of the alimentary canal of a single specimen of $H$. italica, Mg., twenty-four hours after the fly had bitten an infected animal, proved negative. $\neq$ In the Federated Malay States, two experiments in immediate feeding made by Fraser and Symonds with Hcematopota and Trypanosoma evansi (the parasite of surra) likewise failed.§ On the other hand, in various parts of Africa natives are said to attribute diseases of stock to the bites of species of Hcematopota. Thus, according to Dr. Andrew Balfour, on the Blue Nile a species of this genus (probably $H$. taciturna, Austen) known as El Takasha ("the attacking fly") is "credited with causing "swelling of the lungs' in sheep and goats." $\|$ Again, the late Dr. W. A. Densham, in a letter to the author from Masindi, Unyoro, Uganda Protectorate, dated February 8th, 1907, after remarking that the natives in the whole of the Nile Province of Uganda attach no importance to the presence of either Glossina morsitans, Westw., or G. pallidipes, Austen, observed:- "The Nile natives are more inclined to

*Cf. Th. Beling, "Beitrag zur Metamorphose der zweiflügeligen Insecten": Archiv für Naturgeschichte, Jahrg. 41, I., p. 39 (1875).

$\dagger C$ f. W. Lundbeck, "Diptera Danica," Part I., p. 103 (Copenhagen : G. E. C. Gad.London: William Wesley \& Son, 1907).

$\ddagger$ Cf. Drs. Edmond and Étienne Sergent, Annales de l'Institut Pasteur, T. XX., pp. 678-679 (1905).

§ Cf. Sleeping Sickness Bureau, Bulletin No. 5, p. 188 (March, 1909).

$\| C f$. A. Balfour, Second Report of the Wellcome Research Laboratories at the Gordon Memorial College, Khartoum, p. 33 (1906). 
incriminate the Hoematopota as animal disease carriers, especially, I think, $H$. decora." In the Nyasaland Protectorate $H$. noxialis, Austen, is said by Major F. B. Pearce, C.M.G., to be an "especially virulent species, complained of by natives as injuring, if not actually killing, their cattle."

Hæmatopota fulva, Austen.

Annals and Magazine of Natural History, Ser. 8, Vol. I., p. 218 (1908).

Plate XI., Fig. 84.

Up to the present time this remarkable species has been received only from Benguella, Angola, whence the Museum possesses the type and five other females, all of which were captured in February, 1905 (Dr. F. Creighton Wellman). The collector's field-note is as follows:- "Found in sedgy and grass-grown marshes, near large streams. Like others of its genus, a vicious biter; fairly active; twelve specimens taken."

When Homatopota fulva was described, no other species of the genus with a similar coloration was known from any part of the world. Within the last few months however, Prof. Bezzi has described,* under the name Chrysozona (Homatopota) ochracea, a species from the Congo Free State, which is stated to be very closely allied to Hamatopota fulva, Austen, and to differ from it in the presence of a median frontal spot, the absence of a black tip to the antennæ, in the dorsum of the thorax being more distinctly striped, and in the presence of a series of hyaline spots along the posterior margin of the wings.

* Annales de la Société Entomologique de Belgique, T. LII., p. 375 (1908). 


\section{Hæmatopota denshamii, Austen.}

Annals and Magazine of Natural History, Ser. 8, Vol. I., p. 220 (1908).

Plate XI., Fig. 85.

Homatopota denshamii, Austen, has as yet been recorded only from the Nile Province of Uganda, the Lado Enclave, and the Southern Bahr-El-Ghazal (Anglo-Egyptian Sudan). The specimens in the Museum Collection consist of seven females, including the type and three other specimens taken between Nimule and Wadelai, in the Nile Province, Uganda, in June, 1906 (the late $D r . W . A$. Densham), two individuals from Nimule, November, 1904, "on cattle" (Captain E. D. W. Greig, I.M.S.), and an example from the Acholi Country, Uganda (M.T. Dawe). When forwarding his specimens the late Dr. W. A. Densham, in whose memory the species is named, wrote as follows :- "This species was a great pest in June, 1906, between Nimule and Wadelai, especially where the grass was long. It did not occur particularly near water, but chiefly along native paths, through open rolling grassy country. Natives are much annoyed by its bite." Females of this species, from the Southern Bahr-El-Ghazal and the Lado Enclave, are in the possession of the Wellcome Research Laboratories, Khartoum.*

Homatopota denshamii belongs to a group of species, other members of which are $H$. similis, Ricardo, $H$. laverani, Surcouf, $H$. unicolor, Ricardo, H. duttoni, Newstead, and H. copemanii, Austen. In the species belonging to this group the stripes on the dorsum of the thorax are very conspicuous, while in the wings the tips and hind borders are much darker than the rest of the surface. Homatopota pertinens, Austen, which is found from Northern Nigeria to Southern Rhodesia, is somewhat more distantly allied to the group.

* Cf. H. H. King, "Third Report of the Wellcome Research Laboratories at the Gordon Memorial College, Khartoum," p. 211 (1909). 
Hæmatopota pallidipennis, Austen.

Annals and Magazine of Natural History, Ser. 8, Vol. I., p. 402 (1908).

Plate XI., Fig. 86.

The following are the localities, etc., of the nine females of this species in the National Collection, all of which are from Northern Nigeria.-Zaria, 1904 (Captain F.U. Carr, A.V.D.); R. Niger above Bajibo, Nupe Province, November 12th, 1906, " biting native paddler in canoe" (Major C. B. Simonds, R.G.A.); Kontagora, 1907 (J. Brand).

In general appearance Homatopota pallidipennis, Austen, presents some resemblance to $H$. brunnescens, Ricardo, which is found in Uganda and the Nyasaland Protectorate. From the shape of its antennæ, however, the latter species would appear to belong to the genus Parhomatopota, Grünb., and as regards other characters $H$. pallidipennis can at once be distinguished by the colour of the frontal callus (clove-brown instead of cinnamon), the much greyer hue of the body, the coarser wing-markings, and the milky border to the extreme tip of the wings.

Hæmatopota bullatifrons, Austen.

Annals and Magazine of Natural History, Ser. 8, Vol. I., p. 407 (1908).

Plate XI., fig. 87.

This handsome and easily recognisable species has, like the foregoing, up to the present time been received only from Northern Nigeria. The following are the localities, etc., of the five females of Homatopota bullatifrons in the Museum.-Zungeru, June-July, 1905 (Dr. J. M. Dalziel, W.A.M.S.), and July, 1907 (J. Brand) ; Marca, July 4th, and Katsena Allah, Muri Province, August, 1907 ( $J$. Brand). 
-Homatopota bullatifrons is not closely allied to any of its African congeners at present known; the prominent, knob-like frontal callus, to which the specific name refers, and the swollen and fringed hind tibiæ, marked with two pale bands, are clearly shown in the figure.

Hæmatopota brucei, Austen.

Annals and Magazine of Natural History, Ser. 8, Vol. I., p. 413 (1908).

Plate XII., Fig. 88.

The only specimen of this striking species yet received is the type, which was forwarded from Unyoro, Uganda, in 1903, by Colonel Sir David Bruce, C.B., R.A.M.C., F.R.S., in whose honour it has been named. The differences between the present and the following species (Homatopota decora, Walk., - see below, and Plate XII., fig. 89 ) will readily be appreciated on comparing figs. 88 and 89.

Hæmatopota decora, Walker.

Insecta Saundersiana. Vol. I. Diptera. Part V., p. 454 (1856).

Plate XII., Fig. 89.

Hamatopota decora, Walk. (of which $H$. dorsalis, Lw., is a synonym), is a widely distributed species, the range of which is known to extend from Cape Colony to the Lado Enclave, and north-westwards to French Congo, Northern Nigeria, and the French Sudan. The localities, etc., of the thirteen females in the Museum Collection are as follows.-Natal (the type of the species, without precise locality), before 1868 (from the Saunders Collection). Nyasaland Protectorate: Deep Bay, Lake Nyasa, August 21st, 1908 (the late Captain Hallam Hardy, R.A.M.C.). Uganda : Busoga, 1903 (Colonel Sir David Bruce, C.B., R.A.M.C., F.R.S.); 
Nile Province, 1906, "taken on a native" (the late Dr. W. A. Densham). Northern Nigeria: Illorin, August, 1904," also found on road from Illorin to Ogudu; not noticed until about the middle of June" (the Medical Officer, Illorin; received from Sir F. D. Lugard, K.C.M.G., C.B., D.S.O.) ; Kontagora, May 21st, 1907 (J. Brand).

In addition to the foregoing, the writer has also examined a number of specimens of Homatopota decora belonging to the Muséum National d'Histoire Naturelle, Paris, of which the following are the localities and other details :-Delagoa Bay, Portuguese East Africa (Mrs. Monteiro) ; Lado Enclave, alt. 1100 metres, October, 1902 (Du Bourg de Bozas Expedition); French Congo, January, 1907 (E. Roubaud); and Kouri, Upper Volta, French Sudan (Dr. Bouffard).

\section{Hæmatopota mactans, Austen.}

Annals and Magazine of Natural History, Ser. 8, Vol. II., p. 106 (1908).

Plate XII., fig. 90.

So far as can be judged from the specimens already examined, the range of Homatopota mactans, which has not yet been received from West Africa, extends from Mozambique to Somaliland and Abyssinia. The following are the localities, etc., of the thirty-two females of this species in the National Collection.-North-Western Rhodesia: Kasempa District, 1908 (E. A. Copeman). Nyasaland Protectorate: Blantyre District, May, 1905, and Katumbe, North Nyasa, December 6th, 1906 (Dr. J. E. S. Old); Nkata Bay, Lake Nyasa, July 28th and August 20th, and Deep Bay, August 21st, 1908 (the late Captain Hallam Hardy, R.A.M.C.). Uganda: Wadelai, Nile Province, November 24th, 1904 (Captain E. D. W. Greig, I.M.S.). East Africa Protectorate: Baila, Dawa River, December 8th, 1908, "caught on pony; common"; Malka Duggah, Dawa River, December 9th and 10th, 1908, "caught on self and on 
pony ; common" (Dr.R. E. Drake-Brockman). Somaliland, precise locality unknown, 1894 (Th. Greenfield). West Somaliland: Odajida, River Dinnick, November 10th, 1908, "on cattle; scarce" (Dr. R. E. Drake-Brockman). Abyssinia : River Daro, Arussi Country, October 18th, 1908, "caught on cattle" (Dr. R. E. Drake-Brockman). The Muséum National d'Histoire Naturclle, Paris, possesses examples of Hamatopota mactans from Mozambique, 1905 (G. Vasse); the bed of the Dakato River, Ogaden, Somaliland, June, 1901 (Dr. É. Brumpt); and the Errer River, south of Harrar, Abyssinia, August, 1901 (Dr. E. Brumpt).

One of Dr. Old's specimens from Katumbe, Nyasaland Protectorate, was accompanied by the following field-note :" Caught biting cattle: country swampy jungle, with very tall coarse reeds, and forest with low trees. Only game seen were bushbuck, waterbuck, and warthog; old spoor of eland plentiful, as also that of buffalo some months old." According to Dr. DrakeBrockman, H. mactans was very common along the Dawa River, in the north-eastern corner of the East Africa Protectorate, in November and December, 1908.

\section{Hæmatopota coronata, Austen.}

Annals and Magazine of Natural History, Ser. 8, Vol. II., p. 100 (1908), and ibid., p. 279 (description of male).

\section{Plate XII., Fig. 91.}

African specimens of this species have hitherto been received only from Somaliland, whence the Museum possesses three females (including the type), taken in June, 1905 (Dr. R. E. Drake-Brockman); the National Collcction, however, also includes a male from Haithalhim, near Aden, Arabia, March 20th, 1895 (Lieut.-Colonel Yerbury). Three females of Homatopota coronata, collected in the Ogaden country, Somaliland, between the Webi Shebeli and the Web, in September, 1901 (Dr. $\vec{E}$. Brumpt), are in the Muséum National d'Histoire Naturelle, Paris. 
The occurrence of this Somaliland species in the Arabian portion of the East African Subregion of the Ethiopian Region is, of course, in no way surprising, since other and better known African Diptera, such as Tabanus biguttatus, Wied., ${ }^{*}$ and a Tsetse-fly (Glossina tachinoides, Westw.) are found to the east of the Strait of Bab-el-Mandeb.

\section{Hæmatopota torquens, Austen.}

Annals and Magazine of Natural History, Ser. 8, Vol. I., p. 409 (1908).

Plate XII., FIG. 92.

The eight females of this species in the Museum are all from Ashanti, and no examples of Homatopota torquens have yet been received from elsewhere. The localities, etc., of the Museum specimens are as follows:-Insu, Ashanti, August 17th, 1906, and September 4th, 1907, " caught in carriages on Gold Coast Government Railway" (Dr. W. M. Graham, W.A.M.S.); North Ashanti, Northern Territories, Gold Coast, February, 1908 (G. C. Dudgeon). Mr. Dudgeon, who observes that the eyes of $H$. torquens in life are "dull green," remarks that this is "a common species in the Ashanti forests," where it "attacks travellers in hammocks." According to Dr. W. M. Graham, the specimens found on the Gold Coast Government Railway, where the fly is frequently met with in the carriages in the month of September, probably come from the Jym River, which runs parallel with the line for a considerable distance.

Care is needed in order to distinguish Hoematopota torquens, Austen, from H. cordigera, Bigot,-another West African species, which is also found in Ashanti, as well as in Assinie (Ivory Coast), Northern Nigeria, and the Congo Free State ; once the points of difference are appreciated, however, a glance at the scutellum and the first joint of the hind tarsi is all that is necessary. With 
reference to the affinity between $H$. torquens and $H$. cordigera, the author wrote as follows at the end of the original description of the former:- "These two species present a strong similarity to each other in certain details, such as the shape of the frontal callus and antennæ, but $H$. torquens is distinguished, inter alia, by the disc of the scutellum being brown, like the remainder of the dorsum of the thorax, instead of smoke-grey, by the deeper yellow colour of the hair clothing the dorsum of the thorax, the paler femora, the first joint of the hind tarsi being cream-buff except the distal third, instead of entirely brown, as well as by certain differences in the wing-markings."*

Hæmatopota ugandæ, Ricardo.

Annals and Magazine of Natural History, Ser. 7, Vol. XVIII., p. 105 (1906).

Plate XII., Fig. 93.

As yet this species has been received only from Uganda, whence the Museum possesses the type and seven other females, without precise locality, collected in 1903 (Colonel Sir David Bruce, C.B., R.A.M.C., F.R.S.), and two females from the south shore of Lake Albert, collected in 1904 (Captain E. D. W. Greig, I.M.S.). The somewhat peculiar character of the wing-markings, in which, as is shown in the figure, the rosettes are clearly defined and usually have pale buff-coloured centres, render Hamatopota ugandoe easy to recognise.

Hæmatopota lacessens, Austen.

Annals and Magazine of Natural History, Ser. 8, Vol. I., p. 421 (1908).

Plate XII., fig. 94.

Hamatopota lacessens is a small, dusky species, which has hitherto been received only from Northern Nigeria and the Sierra 
Leone Protectorate. The following are the localities, ctc., of the seven females in the National Collection.-Northern Nigcria: Kontagora, September 2nd, 1903 (Surgeon-Major J. J. V. A.C. Raye, W.A.M.S., per Sir Patrick Manson, K.C.M.G., F.R.S.); Zungeru, July 12th, 1905 (Dr.J.M. Dalziel, W.A.M.S.); Zaria, July 15th, and Allowa, Zaria Province, July 19th, 1907 (J.Brand); Keffi, Nassarawa Province, September 4th, 1907, "on horse" (Dr. R. F. Williams, W.A.M.S.). Sierra Leone Protectorate: Kaballa, 1908 (Dr. Murphy, per Dr. R. M. Forde, W.A.M.S.).

This Homatopota, which is said by Surgeon-Major Raye to swarm at Kontagora, would appear to be particularly bloodthirsty. Dr. R. F. Williams writes that it is "a very aggressive biter both of horse and man," and the specimen from Kontagora bit SurgeonMajor Raye and sucked his blood, inside a mosquito-net.

Homatopota tenuicrus, Austen, which likewise occurs in Northern Nigeria, presents some resemblance to $H$. lacessens in facies, and also, like it, has no bands on the hind tibiæ, can be distinguished from the present species by its front tibiæ not being swollen.

\section{Genus HIPPOCENTRUM, Austen.}

Annals and Magazine of Natural History, Ser. 8, Vol. II., p. 352 (1908).

Plate XII., Fig. 95.

The following are the characters that distinguish this genus from Homatopota, Meigen, to which it is allied :- Head (at least in the female) wholly or for the most part shining; antennæ (at any rate in the female) extremely slender and the first joint elongate ; terminal joint of the palpi in the female very large, and shining on the outer side, which is strongly convex, while the inner side is flattened; wings, though more or less suffused with dark colour interrupted by pale streaks or blotches, without the peculiar light 


\section{4}

markings characteristic of Hamatopota. The eye-markings are similar to those in the latter genus.*

The genus Hippocentrum, of which three species have been described, is essentially West African, although the typical species Hippocentrum versicolor, $\dagger$ Austen, has also been met with in the Nile Province of the Uganda Protectorate and in the Lado Enclave. As regards the other two species, Hippocentrum trimaculatum (Hcematopota trimaculata), Newstead,-the range of which is known to extend from the Congo Free State to the Sierra Leone Protectorate and the French Sudan in the region of Lake Chad-is very closely allied to and possibly identical with the third species, Hippocentrum (Hamatopota) strigipennis, Karsch, which was described from four denuded specimens from the Gaboon. Karsch's description of the wing-markings of his species, however, is not quite definite enough to enable a decided opinion to be formed as to whether or not $H$. trimaculatum, Newstead, is really a synonym of $H$. strigipennis, Karsch.

Nothing is yet known of the life-history of the species of Hippocentrum, but the females are pertinacious biters, both of human beings and animals : the generic name $\ddagger$ refers to the typical species, which is said to be very troublesome to horses in Lagos Province, Southern Nigeria. In the resting position the wings are carried as in Hoematopota.

Hippocentrum versicolor, Austen.

Annals and Magazine of Natural History, Ser. 8, Vol. II., p. 354 (1908)

\section{Plate XII., Fig. 95.}

The range of this easily recognisable species extends at least from Northern and Southern Nigeria to the Lado Enclave and the

* In specimens of Hippocentrum trimaculatum, Newstead (see below), preserved in spirit, the eyes appear clove-brown, with four narrow, horizontal, green or bronzegreen stripes, of which those forming the middle pair are more or less sinuous or zigzag.

† See below, and Plate XII., fig. 95.

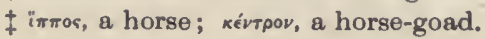


Nile Province of the Uganda Protectorate. The localities, etc., of the eleven females in the Museum are as follows.-Northern Nigeria: Zungeru, July 14th, 1905 (Dr. J. M. Dalziel, W.A.M.S.), and July, 1907 (J. Brand) ; Agwatcha, Bassa Province, July, 1906 (Dr. G. J. Pirie) ; Little Koriga River, July 18th, 1907 (J. Brand). Southern Nigeria : On railway at $57 \frac{1}{2}$ miles camp, Lagos Province, Junc 12th, 1906, "very troublesome to horses" (Dr. R. C. Hiscock, W.A.M.S., per Dr. W. H. W. Strachan, C.M.G.) ; Lower Niger, July, 1906 (G. C. Dudgeon). Lado Enclave, 1907 (Captain T. C. Mackenzie, D.S.O., R.A.M.C., attached E.A.,--per H. H. King). Uganda Protectorate: Nile Province, 1906, "caught on a native in camp; only specimen seen" (the late Dr. W.A. Densham).

The wing-markings of this species render it readily distinguishable from Hippocentrum trimaculatum, Newstead, which, according to Mr. G. C. Dudgeon, attacks travellers in hammocks in the vicinity of the Cross River, Southern Nigeria. In H. trimaculatum the costal cells are not suffused with yellow, there is no conspicuous hyaline or semihyaline base to the wing (although the proximal half, especially anteriorly, is paler than the remainder), and no broad, interrupted, obliquely transverse, hyaline band beyond the middle. On the other hand the wing is much more uniformly suffused with brown (darker in the distal half), and the light marks consist of a more or less indistinct pale transverse mark, in about the middle of the anterior half of the wing and immediately before the proximal end of the stigma, a narrow transverse streak just before the tip of the wing, and a mark between these two descending from the costa at the distal end of the stigma. The median mark of the three is sometimes wider than the others, though it may be very indistinct; it may bifurcate below and even form a more or less complete circle round the fork of the third vein, while occasionally a second small circle is visible below the other. 
CHAPTER VI.

\section{Family MUSCID $\approx$.}

Plate XIII., Figs. 96, 97, ANd 101-103.

Although this family includes some of the most important of all blood-sucking flies, the habit of sucking blood is highly exceptional among its members, and is confined to a very few genera, each of which consists of but a small number of species. The latter all present a general resemblance to the common house-fly, and, with the exception of certain species of Glossina (Tsetse-flies), are all of small size ; it is important to note that, contrary to the usual rule, the blood-sucking habit is common to both sexes. In addition to Stomoxys and Lyperosia, species of which are figured on Plate XIII., and Glossina, the only genera of blood-sucking Muscidæ at present known to occur in the Ethiopian Region are Stygeromyia and Philomatomyia.* Of these the former, which is in some respects intermediate between Stomoxys and Lyperosia, resembles Stomoxys in general appearance and the form of the body, but is distinguished, inter alia, by the relative stoutness of the short, chitinous, horizontal proboscis, and by the palpi being equal to the proboscis in length, large, expanded towards the tips, and curved upwards ; in the wing, the opening of the first posterior cell at the tip is exceedingly narrow (less than half the width of the opening of the same cell in the wing of Stomoxys calcitrans, Linn.), and the bent-up portion of the fourth longitudinal vein is almost or perfectly straight. Founded for Stygeromyia maculosa, Austen, the type of which was taken at Little Aden, Arabia (Lieut.-Colonel

* The genus Beccarimyia, founded by Rondani for B. glossina, Rond. (Eritræa), is now regarded as allied to the genus Stomatorrhina (Idia), and $B$. glossina is believed not to be a blood-sucking species at all (cf. Bezzi, Rendiconti del R. Ist. Lomb. di sc. e lett., Serie II., Vol. XL., 1907, p. 435). Glossinella, Grünberg, for G. schillingsi, Grünb. (Zoologischer Anzeiger, XXX. Bd., 1906, p. 86.-German E. Africa), is a synonym of Lyperosia. 
Yerbury),* the genus Stygeromyia also includes a second specjes, $S$. sanguinaria, Austen, $\dagger$ which has been taken at Ruwe, West Lualaba, Katanga District, Congo Free State (Dr. A. Yale Massey), and at Monkey Bay, Lake Nyasa, Nyasaland Protectorate (the late Captain Hallam Hardy, R.A.M.C.). The type of the male, which was caught in open bush on high ground, attracted Dr. Yale Massey's attention by biting him on the hand, "causing pain similar to that produced by the bite of a Tsetse."

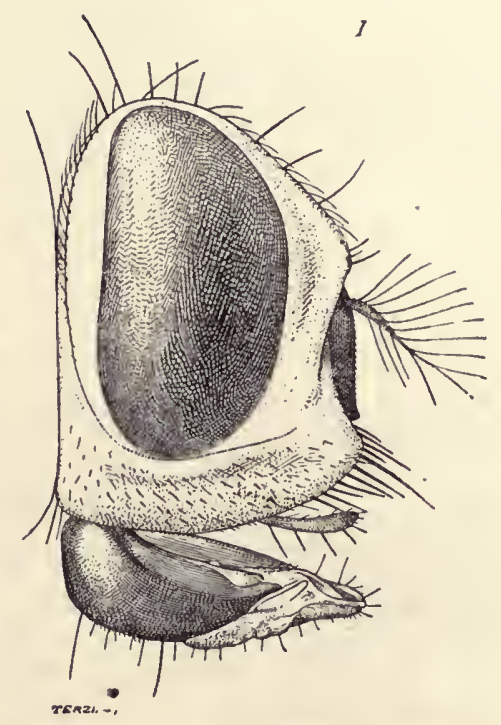

Philoematomyia insignis, Austen.

Fig. I.-Head of $q^{\circ}$ in profile, showing proboscis as it appears when not in use $(\times 25)$.

The genus Philoematomyia, of which but a single, remarkably widely distributed species ( $P$ h. insignis, Austen, - a small greyish fly, not unlike Musca domestica, Linn., in size and general appearance)

* $C f$. E. E. Austen, "A New Genus and Species of Phlebotomic Muscidæ from Aden": Annals and Magazine of Natural History, Ser. 7, Vol. XIX., pp. 445-448 (1907).

†Cf. E. E. Austen, ibid., Ser. 8, Vol. III., pp. 286-288 (1909).

$\ddagger$ For permission to reproduce this figure and the two following illustrations the author is indebted to Messrs. Taylor \& Francis, who have most kindly lent the original blocks. 
has yet been described, ${ }^{*}$ is of peculiar interest owing to the structure of the proboscis. While the proximal portion of this organ is a strongly swollen, polished, chitinous bulb, the distal portion is soft and fleshy, folded back under the distal end of the bulb when not required, but when in use extended, its terminal section
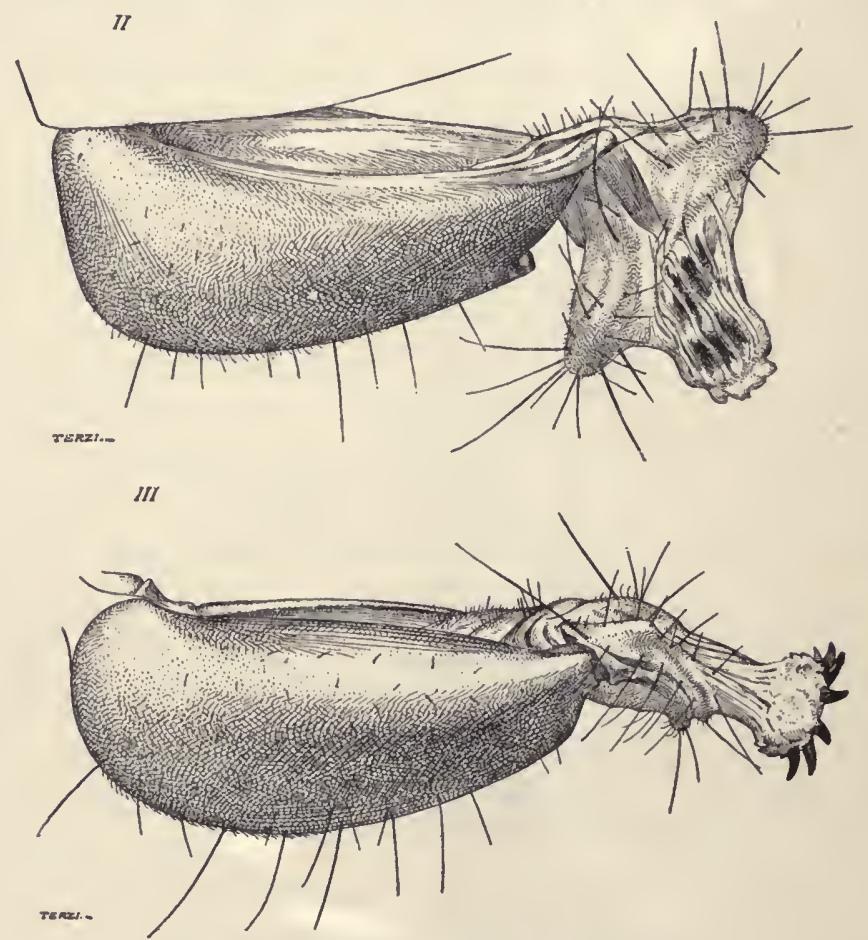

Philamatomyia insignis, Austen.

Fig. II.-Proboscis of $q$, with " tubular extension" not quite fully protruded from between the hairy, fleshy labella ( $x$ about 70 ).

Fig. III.-Proboscis of ${ }^{\circ}$, with tubular extension fully protruded, showing circlet of stout, black, chitinous teeth ( $x$ about 70 ).

consisting of a tubular extension, which is protruded from between the labella, and is surrounded at the distal extremity with a circlet of stout chitinous teeth (compare figs. I., II., and III.). When not in use the proboscis can be entirely retracted within the buccal cavity, so that it is invisible when the head is viewed in profile, but, in dead specimens at any rate, it more usually protrudes,

* Cf. E. E. Austen, loc. cit., pp. 295-299. 
projecting downwards at an angle of about $45^{\circ}$. When the fleshy distal portion is reflexed beneath the distal end of the bulb, the extremity of the proboscis has a pointed appearance. The fleshy portion, which, like the bulb, bears fine hairs, when reflexed ends in the labella, which therefore come to lie between the pointed tip of the proboscis and the rounded base of the bulb, and, when the proboscis in this condition is seen in profile, look like a fleshy pad lying on the under side of the bulb just beyond the middle. When the proboscis is brought into use, the fleshy portion is extended until it lies more or less in a line with the bulb, and the tubular extension (which, in a fly of normal size, is approximately $0.5 \mathrm{~mm}$. in length) is protruded from between the inner surfaces of the labella, of which it forms a prolongation. The extension is supported internally by a pair of stout, black, chitinous rods, which are visible through the semi-transparent wall, and of which the proximal extremities are situate between the tips of the labella. In dried specimens at any rate, the distal extremity of the tubular extension appears to consist of a thickened fleshy ring, armed with pale yellowish teeth or blades in addition to the circlet of stout, black, pointed teeth, which are situate on its inner margin. As regards other characters of Philcematomyia, it need only be said that the eyes are narrowly separated above in the male and wide apart in the female; that the hairs on the arista, or bristle-like process projecting from the base of the third joint of the antenna, instead of being confined to the upper side, as in Stomoxys, Lyperosia, and Stygeromyia, are, as shown in fig. I., present on the under side as well, as in Musca domestica; and that the venation of the wings is approximately the same as in the latter species.

It will be seen that Philcematomyia forms a remarkable connecting link between the Stomoxys group and the ordinary non-biting Muscidæ, in which the broad, fleshy labella at the tip of the proboscis are not adapted for the perforation of the integument of Vertebrates. In the case of Stomoxys and Lyperosia the slender chitinised proboscis (labium) is thrust bodily into the skin of the animal or human being on which the fly is feeding, and so forms a piercing organ, a hole being first cut in the skin by means of the powerful teeth 
on the inner side of the small, externally chitinised labella, which are everted for the purpose. In Stygeromyia, and also in Hamatobia (a genus which occurs in Europe and India, but is not yet definitely known to occur in Africa), the labella, though somewhat larger, are similarly chitinised and armed, and they and the rest of the proboscis doubtless act as in Stomoxys, though it is possible that the proboscis does not penetrate so deeply into the skin of the victim. In Philomatomyia, however, in which the labella are large and fleshy, as in Musca, though, as has been seen, the proboscis is also provided with powerful teeth, there is strictly speaking no actual piercing organ, since the fleshy termination of the proboscis would seem to be incapable of being thrust into the skin of a Vertebrate. The fly therefore in all probability feeds by cutting through the epidermis with the teeth at the end of the tubular extension, and then sucking up the blood in the ordinary way.

Specimens of Philamatomyia insignis, Austen, were taken at St. Louis, Senegal, on May 16th, 1903, "feeding on cattle and donkeys," by the late Dr. H. E. Dutton and Dr. J. L. Todd, and at Zambie, R. Congo, Congo Free State, in September, 1903 (Drs. Dutton, Todd, and Christy); additional examples have also been received from Cyprus, Sokotra, India, and Ceylon. In Cyprus, according to information received from Dr. G. A. Williamson, Ph. insignis attacks human beings and horses, and the latter become very restive when bitten.

The African blood-sucking Muscidæ (exclusive of Glossina) at present known vary in length from about $2.5 \mathrm{~mm}$., in the case of a small specimen of Lyperosia thirouxi, Roubaud, to $7 \mathrm{~mm}$. in that of Stygeromyia sanguinaria, Austen, or a large species of Stomoxys, such as $S$. inornata, Grünberg. The coloration of the body is dull (some shade of grey, brown, or blackish, with darker markings), while the wings, - which in the resting position lie in the horizontal plane, diverge more or less at the tips, and may, as in Lyperosia, overlap to some extent at the base,-are hyaline or infuscated, but never mottled. The horizontal, chitinous, proboscis is visible from above in the case of Stomoxys, but in Lyperosia, in the normal resting position, is concealed by the palpi; in Stygeromyia, owing to 
its relative shortness, the proboscis is scarcely noticeable from above, especially since its extremity is concealed by the tips of the palpi ; in Philomatomyia the tip of the reflexed proboscis is just distinguishable from above, but may easily be overlooked. The sexes are usually very similar, but can at once be recognised by the eyes being much closer together in the males; Stomoxys omega, Newstead (Plate XIII., fig. 96), exhibits an additional secondary sexual character in the presence of a peculiar fringe of hair on the inside of the first two joints of the front tarsi of the male.*

In no case has the breeding of any blood-sucking

Life-history. Muscid (other than Glossina) yet been observed in Africa, but the metamorphoses of species of Stomoxys and Lyperosia have been studied in Europe and the United States, $\uparrow$ while those of Philomatomyia insignis have been investigated in India by Mr. F. M. Howlett. All of these flies breed as a.rule in the fresh droppings of Ungulates, though Stomoxys calcitrans was also noticed by Newstead ovipositing in cut and heated grass. The larvæ are footless whitish or yellowish maggots, of the type of those of Musca domestica or Calliphora erythrocephala, $\mathrm{Mg}$. (the common Blow-fly). Pupation takes place in the ground beneath the dung, and the puparium or pupa-case, which is barrel-shaped or ellipsoidal, slightly narrower in front, varies in colour from red to dark brown.

Blood-sucking Muscidæ (other than Glossina) and Disease.

For the available information on this subject the reader is referred to the notes on Stomoxys calcitrans, Linn., S. nigra, Macq., and the genus Lyperosia (pp. 148, 156, 161).

\section{Genus STOMOXYS, Geoffroy.}

Histoire abregée des Insectes qui se trouvent aux environs de Paris, T. II., p. 538 (Paris : 1762).

Plate XIII., Figs. 96, 97, 101, 102.

Of this genus, exclusive of recognised synonyms, the Ethiopian fauna is known to include ten or eleven species, of which by far the 


\section{2}

commonest and most widely distributed are Stomoxys nigra, Macq. (Plate XIII., fig. 101), and the almost cosmopolitan S. calcitrans, Linn. (Plate XIII., fig. 102). The species of Stomoxys are small greyish, brownish- or blackish-grey, or blackish flies, about 5.5 to $7 \mathrm{~mm}$. in length, in the case of African species, with a slender, shining black, chitinous proboscis projecting horizontally from belleath and in front of the head. Except in the darker species, the thorax is marked with clove-brown or blackish longitudinal stripes, and the abdomen bears brown or blackish spots or transverse bands. The sexes can be distinguished by the eyes being much closer together in the male than in the female; in the case of $S$. omega, Newstead (Plate XIII., fig. 96), a further sexual difference is constituted by a remarkable series of curled hairs on the inside of the front tarsi of the male (see p. 158).

Stomoxys attacks human beings as well as animals, and is capable of inflicting a painful bite, at least a third of the proboscis being driven into the skin.

There can be little doubt that the life-history

Life-history. of all species is similar to that of $S$. calcitrans (see pp. 146-148), the metamorphoses of which have as yet alone been studied.

The available evidence on this subject will be

Stomoxys found fully detailed in the notes on $S$. calcitrans and Disease. and $S$. nigra, which would appear to be the only species with which experiments have yet been made, and to one or other of which all observations refer.

\section{Stomoxys calcitrans, Linnæus.}

Systema Naturæ, Ed. X., T. I., p. 604 [Conops] (1758) : Fauna Suecica, Ed. II., p. 467, 1900 [Conops] (1761).

$$
\text { Plate XIII., Fig. } 102 .
$$

Stomoxys calcitrans, a common and well-known pest of human beings and domestic animals in Europe, and S. nigra, Macq.,* 
are undoubtedly by far the most widely distributed species of Stomoxys in Africa. Although it cannot yet be proved by actual specimens that $S$. calcitrans is of universal occurrence on the African continent, it would seem highly probable that this is so, since the, species is certainly found from Algeria and Egypt to Cape Colony, and from Gambia to the East Africa Protectorate. Outside Africa and Europe, where it occurs everywhere from Lapland southwards, Stomoxys calcitrans exists throughout the greater part of the world. The Museum Collection contains specimens from the Azores, Canary Is., Porto Santo Is., Madeira, the Seychelles Is., Palestine, India, Ceylon, Siam, North China (Wei-Hai-Wei), Queensland, the Sandwich Is., British Columbia, Canada, Mexico, Central America, the West Indies, Brazil (Lower Amazons), and Uruguay; while the species has been recorded from Hong Kong, Batavia, New South Wales, and New Zealand, and is said to be "Very common throughout the inhabited parts of North America."*

As a rule, African examples of Stomoxys calcitrans are smaller than British specimens, while, as is not surprising in the case of so widely distributed a species, the abdominal spots show considerable individual variation in size and shape. The localities, etc., of the African specimens in the Museum are as follows.-Gambia: McCarthy Island, March 27th, 1903, "feeding on horse," and Salikenny, April 23rd, 1903, "in stable" (the late Dr. J. E. Dutton, and Dr. J. L. Todd); precise locality unknown, 1906 (Dr. E. Hopkinson, D.S.O.). Gold Coast: Accra, February 15th, 1907, "on window" (Dr. W. M. Graham, W.A.M.S.). Ashanti : Kumasi, January 25th, 1905, " on horse" (Lieut.-Colonel G. M. Giles, late I.M.S.); Obuasi, April 16th, May 31st, and September 30th, "caught on cattle and in tent," and Prahsu, December 16th, 1907, "in tent" (Dr.W.M.Graham, W.A.M.S.). Northern Nigeria: Keffi, Nassarawa Province, June 19th-22nd, and October 1st, 1907 (Dr. R. F. Williams, W.A.M.S.). Congo Free State : Leopoldville, December 30th, 1903 (Drs. Dutton, Todd, and Christy). Angola: Benguella, February, "generally taken on dogs and other domestic animals;

* J. M. Aldrich. "A Catalogue of North American Diptera," p. 530 (Washington : published by the Smithsonian Institution, 1905). 
quite common," and Bailundo, June 25th, 1905 (Dr. F. Creighton Wellman). Anglo-Egyptian Sudan: Khartoum, May, 1908 (H. H. King). Somaliland: Sheikh, North Somaliland, March 7th, 1907 (Dr.R. E. Drake-Brockman). East Africa Protectorate : Machakos, June, 1898, caught in company with Stomoxys nigra, Macq., sucking the blood of mules suffering from Tsetse-fly disease* (the late Vety.-Captain A. G. Haslam, A.V.D.). Uganda Protectorate : Entebbe, September 24th, 1903 (Dr. D. Nabarro); exact locality unknown, 1907 (the late Dr.W.A. Densham). Zanzibar Protectorate : Pemba I., August 26th, 1899 (Dr. D. R. O'Sullivan-Beare). Portuguese East Africa: Incanine, Lorenzo Marques, December 15th, 1906, "on native" (F. D. McMillan). Natal : Umfuli River, November, 1895, and Estcourt, September and October, 1896 (G. A. K. Marshall). Transvaal: Pretoria, 1904 (Dr. A. Theiler, C.M.G.).

According to Grünberg, $\uparrow$ Stomoxys calcitrans occurs in Togoland, but up to 1906 had not been received from Cameroon; in German East Africa, however, the species is apparently very common. It may be added that $S$. korogwensis, Grünb., $\ddagger$ which was described from a male from German East Africa, is merely a synonym of S. calcitrans, L., and that the difference in the abdominal markings upon which Grünberg relies may be seen in many British specimens, as well as in individuals from other parts of the world. It also seems probable that $S$. sitiens, Rond. (described from a male from Eritræa) is a synonym of $S$. calcitrans, L.

With reference to this species, as met with in Gambia and the Congo Frec State by the members of the Expeditions of the Liverpool School of Tropical Medicine, Dr. J. L. Toddई writes as follows :"This fly was caught in the open and in the houses of Europeans. It feeds on all mammals, but seems to be especially fond of feeding at the tips of dogs' ears. Both on the Gambia and on the Congo

* Cf. Austen, "Monograph of the Tsetse-Flies," p. 304 (1903).

$\dagger$ Zoologischer Anzeiger, XXX. Bd., p. 87 (1906).

$\ddagger$ Loc. cit., p. 88.

\$Annals of Tropical Medicine and Parasitology, Series T. M., Vol. I., No. 1, p. 76 (February 1, 1907). 
dogs were often seen with their ears raw and bleeding from the attacks of this pest." Mr. F. D. MeMillan, writing from Lorenzo Marques, kindly supplies the following note on Stomoxys calcitrans :"Native name C'nane Pungane. This is a horrid little fly that is always biting one, and apparently draws more blood than it can carry away, for it leaves a small clot of blood or else makes such a large hole that blood comes. Sometimes the bite is painful and causes swelling, and sometimes no mark, except the clot of blood, is left. The species is common everywhere, and I have met with it in the Transvaal, Cape Colony, and Natal."* It frequently happens that Stomoxys calcitrans is taken attacking animals in company with S. nigra, Macq., as was done by Dr. W. M. Graham in Ashanti, and by the late Captain A. G. Haslam at Machakos, East Africa Protectorate, in June, 1898. In sending specimens of these two species from Machakos, Captain Haslam wrote to the author on July 3rd, 1898, that he had " caught these flies on every kind of animal, including gazelles, wildebeeste, and all domestic animals, and also on meat exposed for a few seconds." Captain Haslam continued :- " Animals do not object to them much after the preliminary stab with the proboscis. They remain sucking for several minutes, and bulge out their abdomens with blood." $\dagger$ Howard, writing at Washington, U.S.A., states that Stomoxys calcitrans is able to bite "through thin clothing." $\ddagger$ Newstead, who allowed himself to be bitten by a newly emerged male fly, describes the process of feeding and his own sensations as follows :"In sucking blood from the writer's hand the insect sat high upon its legs, but the anterior pair were much elbowed, and all the joints of the tarsi generally rested upon the skin of the host. The whole

* Linnæus's observations, written nearly one hundred and fifty years ago (Fauna Suecica, Ed. II., loc. cit. [1761]), on the behaviour of $S$. calcitrans in Sweden are as follows :- "Habitat ubique. Hæc tibias nostras ingruente præsertim pluvia pungit; hæc, ut continuo calcitrent boves, nec pedibus quiescant, facit; ubi pungit, macula sæpe rubra in medio coccinea, diu durans " "Found everywhere. This fly bites our shins, especially during rain; it makes cattle kick continuously, so that their feet are never still; the place bitten is often marked by a red spot with a scarlet centre, which lasts for a long time").

$\dagger C f$. Austen, "Monograph of the Tsetse-Flies," loc. cit."

$\ddagger$ Cf. L. O. Howard, Proceedings of the Washington Academy of Sciences, Vol. II., p. $578(1900)$. 
of the proboscis was straightened and held vertically, and the anterior third was driven into the flesh [Newstead remarks in a note that:- "In thick-skinned animals the proboscis would in all probability be driven in still further."]. During the process, which lasted altogether for a period of 15 minutes, the proboscis was constantly, but somewhat slowly, moved up and down, and also with an occasional semi-rotary movement, reminding one somewhat of the action of a quarryman's hand drill. This action was continued until the fly had pumped its body full of blood. The initial pain was trifling compared with that of a mosquito; but there were two subsequent pricks which were quite as irritating as the first. A small drop of blood was left over the puncture, and when this was washed away a small roseola was revealed; but there was no subsequent irritation or soreness of any kind. A clear fluid was passed from the anus four times during the process, and on several occasions subsequently, and judging from the size. of the abdomen the food was rapidly assimilated."*

For an account of the anatomy of the mouth-parts of Stomoxys calcitrans, the reader is referred to the excellent and admirably illustrated paper by Stephens and Newstead $\uparrow$ : for the internal anatomy, Tulloch's paper, $\ddagger$ which refers either to this species or to Stomoxys nigra, Macq., should be consulted.

No observations on the breeding-habits of

Life-history Stomoxys calcitrans in Africa have yet been of Stomoxys recorded, but the life-history of the species has calcitrans. been studied in Europe and North America. So long ago as 1834, Bouché stated that the larva

* Cf. R. Newstead, Journal of Economic Biology, Vol. I., pp. 159, 160 (1906), and Annals of Tropical Medicine and Parasitology, Series T. M., Vol. I., No. 1, p. 79 (February 1, 1907).

+ "The Anatomy of the Proboscis of Biting Flies, by J. W. W. Stephens, M.D.Cantab., and R. Newstead, A.L.S., F.E.S.-Part II. Stomoxys (Stable-Flies)" : Annals of Tropical Medicine and Parasitology, Series T. M., Vol. I., No. 2, pp. 171-198, Plates XII.-XIX. (June 15, 1907).-Cf. also Hansen, "The Mouth-Parts of Glossina and Stomoxys,"-Austen's "Monograph of the Tsetse-Flies," pp. 105-120, Plates VIII. and IX. (1903).

‡ "The Internal Anatomy of Stomoxys," by (the late) F. Tulloch, Lieut. R.A.M. Corps: Proceedings of the Royal Society, B., Vol. 77, pp. 523-531, five figures in text (1906).

$\S$ "Naturgeschichte der Insekten," p. 56 (Berlin, 1834). 
was to be found in warm horse manure, in company with that of Musca domestica, L. (the Common House-fly), and in 1889 and 1890 Dr. L. O. Howard reared Stomoxys calcitrans from horse manure at Washington.* In 1906 Newstead, in England, succeeded in inducing a "small percentage" of captive females of $S$. calcitrans to oviposit on fresh droppings of the horse, sheep, and rabbit, and was thus enabled to study the metamorphoses. $\dagger$ Under these circumstances it was found by this author that "two important conditions were necessary for the development of the larvæ, viz., an almost complete absence of light and an abundance of moisture." Subsequently Newstead observed the species of ovipositing under natural conditions, in a heap of cut and heated grass. The following brief summary is based upon Mr. Newstead's paper, $\ddagger$ and upon an examination of material kindly presented to the Museum by him.

The eggs, which are laid in batches usually containing about fifty to seventy, are white, $1 \mathrm{~mm}$. in length, elongate and somewhat resembling a banana in shape, with one side nearly straight and the other curved, and with a broad deep groove on the straight side. At an average temperature of about $72^{\circ} \mathrm{F}$. by day, and $65^{\circ} \mathrm{F}$. by night, they were found to hatch in from two to three days.

The larva, which is a footless maggot of the usual Muscid type, and closely similar in colour and general appearance to that of the Common House-fly, is $11 \mathrm{~mm}$. in length when adult, and "creamywhite to pale ochreous, translucent, shining and almost glass-like" : the black mouth-hooks are visible through the integument of the narrower, cephalic extremity. The larva of Stomoxys calcitrans is distinguishable from that of Musca domestica by the two plates on the posterior surface of the last segment, which bear the respiratory apertures (posterior stigmata), being much smaller, nearly circular (instead of the inner side of each plate being straight), and from four to six times as far apart, with the three apertures in each plate only slightly curved instead of extremely sinuous.

* Cf. Howard, loc. cit., pp. 578-579.

$+C f$. R. Newstead, "On the Life-history of Stomoxys calcitrans, Linn.": Journal of Economic Biology, Vol. I., pp. 157-166, Plate XII. (Reprinted in Annals of Tropical Medicine and Parasitology, Series T. M., Vol. I., No. 1, pp. 76-85, Plate V.).

$\ddagger C$ f. R. Newstead, loc, cit. 
Under favourable conditions, in August in England, the larval stage has been found to last from a fortnight to three weeks.

The pupa or puparium* is barrel-shaped, as in the case of Muscidæ generally, about $5.8 \mathrm{~mm}$. in length, and in colour "bright terracotta red, changing to dark chestnut-brown a few days before the emergence of the fly." In Newstead's hands the duration of this stage. was from nine to thirteen days.

\section{Stomoxys calcitrans as a Disease-Carrier.}

\section{Diseases other than trypanosomiases.}

(1) Anthrax.-In 1878, it was stated by Mégnin that Stomoxys calcitrans and a species of Pangonia (Family Tabanidæ) had been proved (by a veterinary surgeon named Germain, belonging to the French Army) to have been the "principal agents" in the dissemination of an extensive epidemic of malignant pustule in the Isle of Pines, New Caledonia. $\dagger$ The outcome of the summary by Nuttall on the subject of "Anthrax and Flies," $\ddagger$ however, would seem to be that, in default of direct experimental proof, neither Stomoxys calcitrans nor other biting flies can be considered as anything more than fortuitous transmitters of anthrax.

(2) Filariasis.-Investigations carried out at Ostia, in Italy, by Dr. Giovanni Noè,§ tend to show that Stomoxys calcitrans is the intermediate host and transmitter of Filaria labiato-papillosa, Alessandrini,\| of the ox. Noè's studies were not carried to a

* What is seen is really the puparium, or pupa-case, consisting, as in all Muscidæ (and indeed in all Cyclorrhapha,- the great primary division of the Diptera to which the Family Muscidæ belongs), of the hardened and contracted last larval skin; the actual pupa lies within this.

†Cf. Mégnin, Bulletin des Séances de la Société Entomologique de France, année 1878, pp. CXLIV.-CXLV. (1878).

$\ddagger C f$. G. H. F. Nuttall, "On the Rôle of Insects, Arachnids, and Myriapods as Carriers in the Spread of Bacterial and Parasitic Diseases of Man and Animals. A Critical and Historical Study": Johns Hopkins Hospital Reports, Vol. VIII., pp. 2-12 (Baltimore, 1899).

$\S C f$. Giovanni Noè, "Studî sul ciclo evolutivo della Filaria labiato-papillosa, Alessandrini": Atti della Reale Accademia Dei Lincei, Anno CCC. Serio Quinta. Rendiconti, classe di sc. fis., mat. $\theta$ nat. Vol. XII., 2 Semestre, Fasc. 9, pp. 387-393 (1903).

\| Apud Noè (loc. cit., p. 392), F. labiato-papillosa, Alessandrini, is apparently a synonym of $F$. stomoxeos, v. Linstow, which was described from embryoes found in the proboscis of a Stomoxys calcitrans in Prussia. 
conclusion, and up to January, 1909, had not been recorded as having been confirmed by experiments; but it would appear that the embryoes of the parasite pass through the wall of the alimentary canal of the fly and collect in its head, where the larval development is completed within the muscles, and that the adult larva makes its way into the labium of the Stomoxys, and thence into the definitive host. It is interesting to note that numerous dissections of "Homatobia" (almost certainly Lyperosia),-which, according to Noè, are found in swarms on the cattle in the Agro Romano, the collected flies looking from a distance like large black blotches,all proved negative and failed to reveal embryoes of the Filaria, although Noè states that the "Homatobia" persecute the cattle to a much greater extent than does $S$. calcitrans.

\section{Trypanosomiases.}

(1) Surra.-In Java, according to Schat,* Stomoxys calcitrans, L., and Lyperosia exigua, de Meijere, are the chief agents in the transmission of surra. Writing of the same malady in the Philippine Islands, Musgrave and Clegg $\dagger$ state that it has been "conclusively shown" that Stomoxys calcitrans and certain other biting flies transmit the disease.

(2) Other Trypanosomiases (in Africa).—Some three years ago it was proved experimentally by Dr. G. Bouffard, at Bamako, in the French Sudan, that a species of Stomoxys is capable of transmitting Trypanosoma cazalboui, Laveran, the pathogenic agent in a disease called souma, which causes great mortality among cattle, horses, and donkeys in the French Sudan, but is incommunicable to monkeys, dogs, and rodents. $\ddagger$ The experimental transmission was in all probability direct, since a non-infected and an infected calf and forty of the flies were placed in the same stable,

* Cf. P. Schat, "Verdere Mededeelingen over "Surra" ": Mededeel. Proefstation Oost-Java, 3e Ser., No. 44 (1903).

$\dagger C f$. W. E. Musgrave, M.D., and Moses T. Clegg, "Trypanosoma and Trypanosomiasis, with Special Reference to Surra in the Philippine Islands," p. 86 (Manila Bureau of Public Printing, 1903).

$\ddagger C \%$. G. Bouffard, "Sur l'Étiologie de la Souma, Trypanosomiase dn Soudan Français": Comptes Rendus des Séances de la Société de Biologıe, 'T. LXII. (Séance du 19 janvier, 1907), p. 71 et seq. (1907). 
and kept there for two days; the animals had been freed from ticks, and the openings into the stable were protected by wiregauze. In Bouffard's opinion the local abundance of the Stomoxys readily explains the ravages caused by souma among cattle. Unfortunately the species of Stomoxys used in the experiment is doubtful, though there is reason to think that it was either Stomoxys calcitrans, L., or S. nigra, Macq.*

In French Congo, Gustave Martin, Lebøuf, and Roubaud have shown that Trypanosoma brucei, $\mathrm{Pl}$. and $\mathrm{Br}$. (the parasite of nagana) can be conveyed mechanically by either Stomoxys nigra, Macq., or $S$. calcitrans, L. (or perhaps by both). $\dagger$ Three flies (two $S$. nigra and one $S$. calcitrans) were allowed to imbibe a drop of virulent blood, and then, after intervals of from half a minute to a minute and a half, were successively made to bite a healthy kitten, in the blood of which numerous parasites were subsequently found on the twelfth day. From the conditions of the experiment it is uncertain whether the trypanosome was carried by all three flies used, i.e., by both $S$. calcitrans and $S$. nigra. It may, however, be noted that a subsequent experiment by the same investigators on similar lines, in which three S. nigra and a guinea-pig were used, and the intervals were ten minutes in the case of one fly and a quarter of an hour in that of the other two, gave negative results. The authors refer to direct-transmission experiments by Minchin, Gray, and Tulloch in Uganda, with a trypanosome (that of "Jinja" cattledisease) allied to T. brucei and with no interval between the bites, when, by using Stomoxys [either S. nigra or S. calcitrans, or both], one positive result in four was obtained, while the use of Glossina palpalis gave four positive results in five. $\$$ Messrs. Martin, Lebœuf, and Roubaud add:- "It is therefore evident that, even as simple carriers, the species of Glossina are of more

\footnotetext{
* The species was actually described by F. Picard (Bulletin de la Société entomologique de France, 1907, pp. 27, 28) as Stomoxys bouffardi, but the description, which, as I am informed by the author, was based upon specimens in very bad condition, is quite unrecognisable.

$+C$. Gustave Martin, Lebouf, and Roubaud, Bulletin de la Société de Pathologie Exotique, T. I., No. 6, p. 356 (1908).

$\ddagger C f$. Minchin, Gray, and Tulloch, Reports of the Sleeping Sickness Commission of the Royal Society, No. VIII., p. 124 (February, 1907).
} 
importance than those of Stomoxys; yet the rôle of the latter cannot be overlooked."

As bearing on the question of the rôle of Stomoxys as a simple carrier, it may be mentioned that in Uganda Greig and Nabarro never succeeded in conveying trypanosomes from infected to healthy animals by means of Stomoxys, when the intervals were as long as six or twenty-four hours*; and that Greig and Gray similarly failed to convey "Jinja cattle" and mule trypanosomes by the bites of Stomoxys after intervals of eight and twenty-four hours. $\dagger$ As a result of their experiments, Greig and Gray (who appear to ignore cases in which a fly bites a healthy animal immediately after sucking blood from an infected one) write :- "It may be, further, considered proved that Stomoxys cannot convey these trypanosomes from the sick to the healthy animals. This is a matter of great practical importance also, because these flies abound in Uganda." $\ddagger$ An examination of specimens forwarded to the Museum shows that, in these experiments in Uganda, both Stomoxys calcitrans, L., and S. nigra, Macq., were employed.

Experiments on direct transmission of Trypanosoma gambiense by means of any species of Stomoxys do not yet appear to have been made, but the fate of this parasite when ingested with blood by $S$. calcitrans or $S$. nigra would seem to be disappearance (digestion) within two days. According to Dutton, Todd, and Hannington $\S$ :"In the Gambia, trypanosomes, identical with those ingested, were found unchanged in the gut of Stomoxys\| up to twenty hours after they had fed heavily on a horse infected with Trypanosoma gambiense. Longitudinal divisional forms were seen." In Uganda, however, Minchin found that when Stomoxys\| and Mosquitoes were fed upon animals infected with Trypanosoma gambiense, the trypanosomes ingested by the flies "went through the same changes of form and structure as in Glossina palpalis," but that, in Stomoxys, "no

*Cf. Reports of the Sleeping Sickness Commission, No. 5, p. 40 (July, 1905).

$\dagger$ Ibid., No. VI., pp. 203-208.

$\ddagger$ Ibid., p. 209.

$\S$ Annals of Tropical Medicine and Parasitology, Series T.M., Vol. I., No. 2, p. 221 (June 15, 1907).

|| Either Stomoxys calcitrans, L., or S. nigra, Macq., or both.-E.E.A. 
trypanosomes were found on the second day (forty-eight hours) after infection."*

With regard to the trypanosomiasis prevalent at the present time among cattle in the northern area of North-Western Rhodesia, and apparently due to two species of Trypanosoma, $\dagger$ it has recently been stated by Montgomery and Kinghorn that, in the case of at least one herd, "the evidence is suggestive that Stomoxys and Lyperosia had acted as transmitting agents." $\ddagger$ No transmission experiments were performed, but the view of the authors (which certainly receives collateral support from the result of Bouffard's experiments described above) is that the flies in question serve to spread the disease around a homestead, when an infected animal has been introduced into a herd.§ Stomoxys and Lyperosia were taken in the cattle kraal of a farm in the northern part of NorthWestern Rhodesia, and the authors state that specimens of the former "were most frequently met with in villages, but on two occasions were taken from recently shot game." $\|$ The species was evidently not determined, but there can be little doubt that it was either Stomoxys calcitrans or S. nigra, unless, as is quite likely, both species were present. 1

As regards sleeping sickness, Dr. A. G. Bagshawe, in a recent review of the available evidence as to the transmission of the disease, comes to the conclusion that, while occasionally species of Clossina

*Cf. E. A. Minchin, "Investigations on the Development of Trypanosomes in Tsetse-Flies and other Diptera": The Quarterly Journal of Microscopical Science, Vol. 52, Part 2, p. 180 (March, 1908).

$\dagger$ Either T. dimorphon, Dutton and Todd, and T. vivax, Ziemann, or closely allied forms.

$\ddagger C f$. R. Eustace Montgomery and Allan Kinghorn, Annals of Tropical Medicine and Parasitology, Series T.M., Vol. II., No. 2, p. 129 (June 9, 1908).

§ Martini, however, working in Berlin with the parasite of nagana, found (apud Musgrave and Clegg, op. cit., p. 85) that this trypanosome was not transmitted from sick horses to healthy horses and asses, though the animals were standing next to one another, and Stomoxys calcitrans was present in numbers on the sick horses. This, it may be remarked, was in accordance with Bruce's experience in Zululand (cf. Surgeon-Major [now Colonel Sir] David Bruce, A.M.S., "Furtlier Report on the Tsetse-Fly Disease or Nagana in Zululand," p. 5. London: Harrison \& Sons, 1897).

|| Montgomery and Kinghorn, loc. cit., p. 128.

TIn their "Conclusions" on p. 131 of their paper, Montgomery and Kinghorn speak of the Stomoxys as "Stomoxys calcitrans," but there is no evidence that the determination was made by a Dipterist. 
other than G. palpalis, and "Stomoxys or even Mosquitoes . . . in rare instances " may act as transmitters, until there is more reason to suspect these flies than at present exists "they may be for practical purposes neglected."*

Summarising what has been stated above, it may be regarded as proved that Stomoxys calcitrans, L., as also S. nigra, Macq., and probably other species of the genus can convey trypanosomes directly from an infected to a healthy animal, when the bites follow one another immediately. On the other hand, the evidence tends to show that, when the interval between the bites is longer (the maximum period within which a bite is infectious has not yet been determined), although active trypanosomes may be present in the intestine of the fly its bite is innocuous. There is no indication that trypanosomes ingested by $S$. calcitrans pass through a developmental cycle, and they apparently disappear within fortyeight hours. With regard to diseases other than trypanosomiases, there are some grounds for thinking that $S$. calcitrans, like other biting flies, may occasionally disseminate the bacillus of anthrax, and, in Europe, it would appear that the fly is the intermediate host of a species of Filaria parasitic in cattle.

\section{Stomoxys nigra, Macquart.}

Diptèrés Exotiques, 4e Supplément, p. 239, Tab. 22, fig. 5 (1850) : Mémoires de la Société Nationale des Sciences, de l'Agriculture et des Arts, de Lille. Année 1850. P. 212 (Lille, Paris, 1851).

Plate XIII., Fig. 101.

As already stated at the commencement of the notes on the foregoing species, Stomoxys nigra, Macq. (of which S. glauca, Grünb., is a synonym), and S. calcitrans, L., are by far the most widely distributed representatives of their genus in Africa. In many localities the two species occur together, and though it is possible

* Sleeping Sickness Bureau, Bulletin No. 2, p. 72 (December, 1908). 
that the range of $S$. nigra does not extend so far to the north and south as that of $S$.calcitrans, throughout Tropical Africa at any rate the present species, which swarms in many localities, may be said to be generally distributed. - Beyond the confines of Africa Stomoxys nigra, Macq., occurs in Réunion I., whence the type of the species was obtained, in Mauritius, ${ }^{*}$ where it is believed to disseminate surra among domestic animals, and in the Seychelles Is., while what appears to be a form of the species has been found in Calcutta. The localities, etc., of the African specimens of $S$. nigra in the National Collection are as follows.-Gambia: Salikenny, April 22nd and 23rd, 1903, "caught in stable" and "feeding on horse" (the late Dr. J. E. Dutton and Dr. J. L. Todd). Sierra Leone, August 12th, 1904, "on window" (Major F. Smith, D.S.O., R.A.M.C.). Ashanti : Kumasi, 1905 (Dr. H. A. Chaplin), and January 25th, 1905, "on horse" (Lieut.-Col. G. M. Giles, late I.M.S.); Obuasi, April 16th and 18th, and June 14th, 1906, June 5th, 1907 ("caught on oxen"), and June 11th, 1907, "in empty hospital" (Dr.W.M. Graham, W.A.M.S.). Gold Coast: Sekondi, October 16th, 1906 (Dr. W. M.Graham). Northern Nigeria: Zaria, 1904 (Captain F. U. Carr, A.V.D.) ; Ndeji Guzan, Nupe Province, June 12th, 1907 (E. C. Duff); Keffi, Nassarawa Province, June 15th-24th, and September 30th, 1907 (Dr. R. F. Williams, W.A.M.S.). Southern Nigeria: Lagos Province, on railway at 85 miles camp, June 7 th, 1906, "plentiful in stable" (Dr. R. C. Hiscock, W.A.M.S., per Dr. W. H. W. Strachan, C.M.G.). Congo Free State: Nouvelle Anvers, September 26th, 1903, and "caught on shot buffalo, four hours in canoe north of Sendwe, November 9th, 1904" (Drs. Dutton, Todd, and Christy). Anglo-Egyptian Sudan: Kodok, Upper White Nile, July, 1907, "in swarms" (H. H. King); Dēm Zobeir, Bahr-El-Ghazal, 1903 (Captain G. S. Nickerson, R.A.M.C., attached E. A., per the late Major T.E. N. Lewis, A.V.D.). East Africa Protectorate: Ngatana, 1893 (Dr.J.W. Gregory); Machakos,

* Stomoxys lafonti, Picard (Bulletin de la Société Entomologique de France, Séance du 23 janvier, 1907, p. 28), from Mauritius, is a synonym of S. nigra, Macq., as I have been able to convince myself by comparing specimens forwarded by M. Picard with the type of S. nigra, kindly lent by Mr. G. H. Verrall, in whose possession it now is. Macquart evidently failed to notice that his type is discoloured, and the description of the abdomen as " $d$ 'un noir mat" is misleading. 
June, 1898, caught in company with Stomoxys calcitrans, L., sucking the blood of mules suffering from Tsetse-fly disease* (the late Vety.-Captain A. G. Haslam, A.V.D.) ; Nairobi, April 5th, 1900 (Captain Richard Crawshay). Uganda: Entebbe, September 24th, 1903 (Dr. D. Nabarro), and 1904, "very common on windows of laboratory" (Captain E. D. W. Greig, I.M.S.). Zanzibar Protectorate: Pemba I., August 26th, 1899 (Dr. D. R. O'SullivanBeare). Nyasaland Protectorate : Lunyina River, Henga, $3000 \mathrm{ft}$., January 29th, 1894 (Captain Richard Crawshay); exact locality unknown, 1907 (Dr. J. E. S. Old).

With reference to Stomoxys nigra in Ashanti Dr. W. M. Graham has kindly supplied the following note :- "This species is the chief cattle-plague in Ashanti; it frequently accompanies cattle in clouds, which, however, are partly composed of S. calcitrans. After feeding, these flies leave the cattle and settle on the leaves of neighbouring shrubs, where they can be easily caught; the abdomens of gorged flies are visibly distended and of a dull red colour. I have sometimes observed streaks of blood on the leaves on which the flies have settled, and marks of blood are also seen on the cattle." Besides attacking cattle, $S$. nigra is a pest of horses and other domestic animals, and Dr. Graham remarks that it "also attacks man." Writing from Keffi, Nassarawa Province, Northern Nigeria, in October, 1907, Dr. R. F. Williams said of S. nigra:- "These flies were not seen during April and May, but were abundant in Keffi in June, when they swarmed on horses ; in September they were not nearly so plentiful. They do not worry human beings if able to attack a horse." Of Stomoxys nigra as observed in the Congo Free State by the members of the Expedition of the Liverpool School of Tropical Medicine, 1903-05, Dr. J. L. Todd writes $†$ :- "Specimens were caught about cattle and in a European house. It feeds vigorously." At Nairobi, East Africa Protectorate, in April, 1900, Captain Richard Crawshay found this

* Cf. Austen, "Monograph of the Tsetse-Flies," p. 304 (1903).

$\dagger$ Annals of Tropical Medicine and Parasitology, Series T.M., Vol. I., No. I. (February 1, 1907), p. 86. - The species is referred to in error as "Stomoxys sitiens, Rond." 
species "plentiful, and a painful biter in the early mornings after sunrise."

On this subject the reader is referred to what Stomoxys nigra has been written above, under the headings as a "Stomoxys calcitrans as a disease-carrier. . . . Disease-Carrier. Other Trypanosomiases (in Africa)," especially the concluding remarks on p. 153 . It will be seen that, in experiments on the transmission of trypanosomes by Stomoxys in Uganda and other parts of Africa, S. nigra as well as S. calcitrans was used, so that the results must be taken as applicable to both species. As already stated, it has been shown by experiment that Stomoxys nigra, Macq., like S. calcitrans, L., "can convey trypanosomes directly from an infected to a healthy animal, when the bites follow one another immediately." Apart from the experimental evidence, such as it is, one or two observations with reference to $S$. nigra as a disease-carrier may be mentioned for what they are worth. Thus, a tube of specimens of this species in the Museum Collection, collected at Ngatana, East Africa Protectorate, by Dr. J. W. Gregory in 1893, bears the label in Dr. Gregory's handwriting :- "Blood-Sucking Flies (Killed our Camels)." In a letter written on November 11th, 1903, when forwarding the examples of S. nigra collected by Captain Nickerson at Dēm Zobeir, in the Bahr-El-Ghazal Province of the AngloEgyptian Sudan, the late Major Lewis (who at that time had recently returned from the Sudan) stated that the flies were " responsible (either directly, or as vehicles of some organism) for a form of virulent disease among donkeys, mules, horses, and camels." It may be observed that, since Glossina morsitans, Westw., occurs at and in the vicinity of Dēm Zobeir, the idea naturally suggests itself that the disease may have been nagana, and that if Stomoxys nigra was indeed concerned in its dissemination, the flies may have conveyed the trypanosome directly from animal to animal, as suggested by Montgomery and Kinghorn in the case of cattle-trypanosomiasis in North-Western Rhodesia.* In a subsequent letter, however, Major Lewis wrote:-"There is not 
the slightest doubt that the flies were responsible for the clinical conditions among donkeys, mules, etc., to which I referred, although the symptoms of disease produced were not those of the so-called 'Horse-Sickness' (as occasioned by the trypanosome through the medium of the Tsetse-fly)." It has already been mentioned that in Mauritius, where the species is extremely abundant, Stomoxys nigra is believed to disseminate surra among domestic animals (horses, mules, and cattle), ${ }^{*}$ although as yet no systematic attempt seems to have been made to prove this by experiments. $\dagger$

Stomoxys omega, Newstead.

Annals of Tropical Medicine and Parasitology, Series T.M., Vol. I. No. I. P. 87, Plate III., figs. 2, 3 (February 1, 1907).

Plate XIII., fig. 96 (male).

This very distinct species, which owes its name to the fact that, in front of the transverse suture, the usual dark longitudinal stripes on the dorsum of the thorax are modified so as to form a figure somewhat resembling the Greek $\Omega$, was described from specimens from the Congo Free State, and has hitherto been received only from West Africa. The localities, etc., of the eight examples (two males and six females) in the Museum are as follows.- Sierra Leone, August 12th, 1904, "on window-pane" (Major F. Smith, D.S.O., R.A.M.C.). Ashanti : Obuasi, May 22nd, 1906, July 28th and November 28th, 1907 (the two latter specimens "caught on

* Of. Lieut.-Colonel N. Manders, R.A.M.C., "Surra as it occurs in Mauritius": Journal of the Royal Army Medical Corps, Vol. V., No. 5, pp: 623-626 (November, 1905). - In this paper the fly is erroneously referred to as "Stomoxys geniculatus, de Bogot."

† According to Drs. Alexander Edington and John Morton Coutts ("A Note on a Recent Epidemic of Trypanosomiasis at Mauritius ": The Lancet, October 5th, 1907), "enormous numbers" of the trypanosome of this disease are readily found in the stomachs of specimens of Stomoxys nigra in Mauritius, where the fly is known as the mouche bouf. The authors in question add that: "M. Daruty de Grandpré, Curator of the Museum at Mauritius, succeeded in infecting a healthy dog, to which he applied eight flies." No details, however, are given. 


\section{8}

window"), and Kumasi, October 26th, 1907, "caught under leaf in bush-path" (Dr. W. M. Graham, W.A.M.S.). Congo Free State: "caught on shot buffalo four hours canoe journey above Sendwe, November 9th, 1904"* (Drs. Dutton, Todd, and Christy). The latter specimens (a male and female) are among those referred to by Dr. J. L. Todd, $\uparrow$ in the following note on Stomoxys omega as met with in the Congo Free State by the members of the Expedition of the Liverpool School of Tropical Medicine to the Congo, 1903-05. "This fly," writes Dr. Todd, "was seen only near water. Some were caught in canoes, others on a buffalo shot in a marsh, on which they were feeding. When the buffalo was first seen it was lying half-covered in water, no doubt to avoid the Stomoxys, which were present in almost incredible numbers."

A remarkable feature exhibited by the male of this species, which is indicated as well as possible in the figure, is a fringe of long, fine, curled hair on the inner side of the first two joints of the front tarsi. The front tibiæ, too, in the same sex, have a thickish fringe of straight hair on the posterior side of their distal halves. The female of $S$. omega closely resembles that of $S$. inornata, Grünb. (Plate XIII., fig. 97), but may be distinguished by the narrower front, by the upper inner margins of the eyes bordering the front being exactly parallel instead of slightly divergent below, by the conspicuously shorter proboscis, and by the marking of the anterior portion of the dorsum of the thorax in front of the transverse suture. In the female of the present species the $\Omega$-like marking, though less distinct than in the male, is still visible; in the female of $S$. inornata, however, there is no such marking, but simply a broad clove-brown or black stripe on each side of the median grey one; the clove-brown or black stripes have their inner margins straight, their outer margins convex, and at their anterior extremities are much narrower than where they meet the transverse suture.

* With Stomoxys nigra, Macq.,-ct. p. 154.

† Annals of Tropical Medicine and Parasitology, Series T.M., Vol. I., No. I., p. 88 (February 1, 1907). 
Stomoxys inornata, Grünberg.

Zoologischer Anzeiger, XXX. Bd., pp. 90-91, Fig. 15 (1906).

Plate XIII., Fig. 97.

Stomoxys inornata, which is the darkest of all the species of Stomoxys at present described, has hitherto been collected only in Cameroon, where the types of the two sexes were obtained, and Ashanti, where a dozen examples (two males and ten females) were taken by Dr. W. M. Graham in 1907. The localities, etc., of the latter specimens, which are the only ones at present in the Museum, are as follows.-Obuasi, July 15th, 28th, and 31st (including a pair in coit $\hat{u}$ ), "on and under leaves in bush-path"; Kumasi, October 21st, " on road beyond Amakoom "; Yankumasi, December 13th, "on leaf on road"; and Adembra, December 20th, "on leaf in bush-path, 9.0 a.m." Dr. Graham has kindly supplied the following note on this species as met with by him :- "Common on all roads visited by me in Ashanti, but difficult to find owing to its dark colour and habit of hiding under leaves. I have always found it associated with Glossina palpalis, Rob.-Desv., to which it is very similar in habits, except that it does not settle on the ground. I have never seen it bite."

In the male of $S$. inornata the median grey stripe on the anterior portion of the thorax is usually so much reduced as merely to appear like a small light spot on the front margin, while the grey stripe on each side, running from the humeral callus to the base of the wing, is also less conspicuous than in the female, and the wings are often much darker. Notes on the differences between the female of the present and that of the foregoing species have already been given in the remarks on the latter. 
Genus LYPEROSIA, Rondani.

Dipterologiæ Italicæ Prodromus, Vol. I., p. 93 (1856), and Vol. V., p. 230 (1862).

Plate XIII., FIG. 103.

The genus Lyperosia is distinguished from Stomoxys by the palpi being broader, more or less flattened from side to side, and as long or almost as long as the proboscis, instead of filiform, not more than half as long as the proboscis or considerably shorter even than this, and not or scarcely projecting beyond the anterior margin of the buccal cavity. When the insect is not engaged in feeding, the palpi are closely applied to the proboscis and conceal it, as in the case of Glossina, palpi and proboscis together looking like a relatively rather stout horizontal process in front of the head; it should be noted, however, that in dead specimens the proboscis almost invariably droops more or less, and may even assume a vertical position. The species of Lyperosia, which are few in number, are the smallest of blood-sucking Muscidæ, and none of the six or seven* African species at present known exceeds $4 \mathrm{~mm}$. in length. The coloration of the body is dull and inconspicuous,-grey, olivaceousgrey, or brownish, with darker longitudinal markings on the thorax ; L. punctigera, Austen (Plate XIII., fig. 103), is characterised in addition by the presence of dark spots on the abdomen. The eyes are narrowly separated above in the male, but are wider apart in the female; the wings are hyaline or slightly brownish.

These little flies often swarm on domestic animals (horses, cattle, and camels), and sometimes also attack human beings. $\dagger$ The European L. irritans, Linn., which has been introduced into the United States of America, is there known as the "Horn-fly," owing to its habit of clustering in a dense mass or ring about the base and on the concave side of the horns of cattle.

* Lyperosia longipalpis, Roubaud (Comptes Rendus Hebdomadaires des Séances de la Société de Biologie, 1906, p. 896, fig. 2-Senegal) is very possibly a synonym of L. minuta, Bezzi.

$\uparrow$ See below, p. 162. 
The only species of Lyperosia of which the

Life-history. biology has yet been studied is the one just mentioned, the life-history of which has been investigated in America by Riley and Howard.* According to these authors, L. irritans oviposits on freshly dropped cow-dung; the eggs, which are "laid singly, and never in clusters, and usually on their sides on the surface of the wet dung; seldom inserted in cracks," are light reddish brown in colour, irregularly oval in shape, flattened on one side, and from 1.25 to $1.37 \mathrm{~mm}$. in length, by 0.34 to $0.41 \mathrm{~mm}$. in width. The newly-hatched larvoe, which are pure white, descend into the dung; when full-grown the larvæ are dirty white in colour and $7 \mathrm{~mm}$. in length. The posterior stigmatic plates, situate on the hinder surface of the terminal or anal segment, are large, very dark brown, nearly circular but with the adjacent inner margins almost straight, and have each a circular central orifice. On the ventral surface of the anal segment is "a dark yellow chitinous plate showing six irregular paired tubercles"; this plate is surrounded by an area of rather coarsely granulated skin. Pupation takes place in the ground beneath the dung, at a depth of from half to three-quarters of an inch in the case of larvæ in dung lying on fine sand. The puparium, or pupa-case, is of the normal Muscid type, dark brown in colour, barrel-shaped, and from 4 to $4.5 \mathrm{~mm}$. in length, by 2 to $2.5 \mathrm{~mm}$. in width.

It is probable that Lyperosia does not often Lyperosia attack man, at any rate when it can get access and Disease. to domestic animals or big game, and it is not likely that flies belonging to this genus will prove to be disease-carriers among human beings. With regard to Lyperosia and animal trypanosomiases very little can yet be said, and for Africa at any rate there is no experimental evidence available. As has already been stated, Montgomery and Kinghorn have recently expressed the opinion that in North-Western Rhodesia at the present time trypanosomiasis is disseminated in herds of

*Cf. Riley, C. V., and Howard, L. O., “The Horn-Fly (Hamatobia serrata, Robineau-Desvoidy)" [= Lyperosia irritans, Linn.]: Insect Life, Vol. II., pp. 93103, Figs. 11-15 (1889). 
162

cattle by the agency of Lyperosia (sp. incert.) as well as Stomoxys.* In Java, according to Schat, Lyperosia exigua, de Meijere, and Stomoxys calcitrans, Linn., play the chief part in the transmission of surra.†

\section{Lyperosia punctigera, Austen.}

Annals and Magazine of Natural History, Ser. 8, Vol. III., p. 285 (1909).

\section{Plate XIII., FIG. $103 . f$}

As yet this species has been received only from the Uganda Protectorate, whence the Museum possesses two females (the co-types) from the Nile Province, June, 1906 (the late Dr. W. A. Densham). The collector's field-note is as follows:- "These flies were noticed in great numbers in one camp only near the Nile, and were very troublesome to my boys early one sunny morning; they clustered thickly on any small sore, and quickly filled themselves; though preferring to feed in this way, they scemed also to insert the proboscis into sound skin."

The conspicuous abdominal markings seen in this species are an unusual feature in Lyperosia, and will enable $L$. punctigera to be distinguished without difficulty from any of its congeners hitherto described.

*Cf. p. 152.

$†$ Cf. P. Schat, "Verdere Mededeelingen over "Surra" ": Mededeel. Proefstation Oost-Java, 3o Ser., No. 44 (1903).

$\ddagger$ It should be noted that in the case of this figure the magnification is twice that of the other figures on Plate XIII. 


\section{CHAPTER VII.}

\section{Family HIPPOBOSCID AE.}

Plate XIII., Figs. 98-100.

Apart from structural characters, the strange-looking flies belonging to this family differ from all those previously dcalt with in two peculiarly important respects, namely in their mode of life and method of reproduction. Instead of flying about freely likc other blood-sucking flies, and as a general rule only settling on a Vertebrate in order to feed, the Hippoboscidæ are permanent parasites of mammals and birds, scldom leaving their hosts under normal conditions *; stray specimens which occasionally alight on human beings usually at once endeavour to hide themselves in the hair or beard. Secondly, instead of laying eggs, the female Hippoboscid produces at intervals a single full-grown larva, which assumes the pupal state immediately after extrusion.

In appcarance the Hippoboscidæ (which vary in length from a little over $3 \mathrm{~mm}$. in the case of a small Lipoptena, to $11.5 \mathrm{~mm}$. in that of a female Hippobosca camelina, Leach, with abdomen distended by its offspring) arc flat-bodied, horny-looking flies, with long wings in the known African forms, and powerful legs. While the head as well as the thorax is flattened and shining, the abdomen is sac-like, devoid of the ordinary indications of segmentation, and of a leathery aspect; this howcver does not affect the general appearance, since the abdomen is usually entirely or partially concealed by the wings, which when not in use lie closcd flat one over the other like the blades of a pair of scissors, as in the Tsetse-flies, and in this position project a considerable distance bcyond the end of the body (see Plate XIII., figs. 98, 99). The general coloration of head and

* In the case of Stenopteryx hirundinis, Linn., and Oxypterum pallidum, Leach, which in the Palrarctic Region are parasitic respectively on the House Martin (Chelidon urbica, Linn.) and the Swift (Cypselus apus, Linn.), the flies are found in the nests as well as on the birds themselves. 
thorax is some shade of brown (yellowish-, reddish-, or clove-brown), and in Hippobosca (see Plate XIII.) the thorax is conspicuously mottled with yellow. The eyes are widely separated in both sexes; the antennæ, which are inserted in pits or depressions near the margin of the buccal cavity, are invisible from above in Hippobosca, but in genera the species of which are parasitic on birds they are large, prominent and scale-like, and bear long hair. In all Hippoboscidæ the palpi are in the form of a pair of rigid chitinous lobes or narrower processes, which project downwards or forwards, and constitute a partial sheath or protection for the proboscis. The latter, which is composed of the same parts as that of the bloodsucking Muscidæ, is curved, extremely slender, and protrusible, being entirely withdrawn from view when not in use. In appearance it presents a decided resemblance to the proboscis of the Tsetse-flies, and it also acts in a similar manner, its tip being armed with sharp chitinous teeth which enable the organ to pierce the skin of the host.*

Leaving the genera Lipoptena and Echestypus out of the question, the wings in all species at present known to occur in the Ethiopian Region are long, generally more or less infuscated, and have the principal veins approximated to the costal (anterior) border; the wings - of species belonging to the genera Olfersia, Pseudolfersia, Lynchia, Ornithoica, and Ornithomyia, which are parasitic on birds, exhibit in addition less strongly developed veins running obliquely across the surface.

The genus Lipoptena is represented in Africa by L. chalcomeloena, Speiser, which is parasitic upon ibex in the Anglo-Egyptian Sudan and Egypt, and by the European $L$. cervi, Linn., which besides occurring in Algeria and Egypt, appears to have been introduced into South Africa with remounts during the Boer War; in this genus the wings are shed by the female almost invariably, and by the male frequently, on reaching a suitable host, and like Melophagus ovinus, Linn. (commonly known in England as the "Sheep Tick"), which is entirely apterous, specimens of Lipoptena which have shed

* For an account of the structure and mode of action of the proboscis, cf. F. H. Müggenburg, "Der Rüssel der Diptera pupipara": Archiv für Naturgeschichte, 58 Jahrg., I. Bd., pp. 287-332, Taf. XV., XVI. (1892). 
their wings present little resemblance to an ordinary fly. The purely African genus Echestypus, Speiser, the three species of which at present known are parasitic on antelopes, is distinguished from Lipoptena by the absence of ocelli. Melophagus ovinus, which is a European parasite of sheep, has not yet been recorded from any African locality ; there can, however, be little doubt that in South Africa as in North America it has been introduced with its host, and a brief search of the fleeces of any South African flock would probably suffice to reveal it.

The legs in Hippoboscidæ are of moderate length, powerfully developed, and otherwise adapted for clinging to the hair or feathers of the host, the tarsal claws, which are of unusual strength and shape, having a special process (basal plate) at the base, with, in the bird parasites, with the exception of Ornithoica, the addition of a long accessory tooth.

It is probable that the Hippoboscidæ are descended from ancestors belonging to the Muscidæ, which underwent modification in bodily structure as a consequence of the adoption of a parasitic mode of life. Whether, as in the case of phlebotomic Muscidæ, both sexes suck blood is not yet known. The bites of Hippoboscidæ do not seem to be painful, and to hosts accustomed to their presence little annoyance is apparently caused by these flies; a strange horse or dog however is often greatly worried by a single Hippobosca, owing to the irritation produced by the movement of the fly through the hair. Except for some special reason, as when forced to seek other quarters owing to the death of their host, Hippoboscidæ as a rule make little use of their wings, but on occasion their flight is quick and short, and they sometimes settle on and occasionally bite human beings.*

The mode of reproduction of Hippoboscidæ is

Life-history. a further development of the process seen in the Tsetse-flies. Instead of, like ordinary Diptera,

* See notes on Mippobosca maculata, Leach. So far as Africa is concerned, no instance has been recorded of a bird-parasite belonging to this family biting man, but the author has been informed by Dr. D. Sharp that in the north of Scotland, according to Mrs. L. Duff Dunbar, of Thulachan, Caithness, a gamekeeper in the employ of the lady mentioned was once severely bitten by Ornithomyia lagopodis, Sharp, from Red Grouse. 
laying eggs or producing a number of small living larvæ, which lead a free and active existence, feeding until full-grown, the fcmalc Hippoboscid, as already stated, produces at intervals a single adult larva, which, as in Glossina, is retained within the oviduct of the mother and nourished until maturity by means of the secretion of a pair of greatly ramified glands. But while, except for the "black hood" at the posterior extremity, the Tsetse-fly larva on being deposited looks like an ordinary maggot, shows distinct segmentation, and is capable of crawling actively away to seek a hiding-place in which to pupate, the Hippoboscid larva on extrusion is a sac-like, ovoid or flattened globular body, which exhibits little or no trace of segmentation, and is entirely incapable of movement. On being deposited, a larva belonging to the present family is whitish or yellowish in colour, with (except in Melophagus) a conspicuous black area or cap (divided into six radial tubercles with intervening furrows in the genus Ornithomyia) at the posterior pole, and a small depression or papilla at the opposite one marking the position of the mouth. In the centre of the black cap (which is obviously reminiscent of the "black hood" of the larva of Glossina) are situate the posterior stigmata or respiratory apertures (in a deep pit in the larva of Ornithomyia), while on the ventral surface in the middle line, just in front of the black cap, is seen the small circular anus. Within a very short time after extrusion the larva becomes converted into a pupa without any modification in form, the change being indicated by the chitinisation and darkening of the larval skin to constitute the puparium or pupal envelope; by this alteration in colour the contrast between the black cap and the remainder of the integument becomes obliterated. The perfect insect subsequently makes its escape by splitting off a cap from the anterior pole of the puparium, after the manner of the Muscidæ.

There is at present nothing to connect any species Hippoboscidæ of Hippoboscidæ with disease among human and Disease. beings, and from the mode of life of these flies it is $\hat{d}$ priori improbable that they will ever prove to be disseminators of micro-organisms pathogenic to man. On 
the other hand two species of Hippobosca are said to be capable of disseminating a trypanosomiasis of cattle in the Transvaal, ${ }^{*}$ and one of these species has been associated, though without proof or anything in the shape of experimental evidence, with a form of anthrax affecting horses in a part of Cape Colony.

Genus HIPPOBOSCA, Linnæus.

Fauna Suecica, Ed. II., p. 471 (1761).

Plate XIII., figs. 98-100.

The easily recognisable species belonging to this genus, which, with one remarkable exception (Hippobosca struthionis, Janson, Plate XIII., fig. 98), are all parasitic upon mammals (horses, donkeys, camels, cattle, or dogs), have a horny appearance so far as regards the anterior half of the body, which is alone visible in the living insect under normal conditions. The thorax, which varies in coloration from yellowish- or reddish-brown to clove-brown, is conspicuously spotted or otherwise marked with yellow, and, as may be seen from the figures on Plate XIII., these markings afford a ready means of distinguishing the species. The abdomen,--normally concealed by the closed wings, which, as in the Tsetse-flies, lie flat one over the other like the blades of a pair of scissors, and project a long way beyond the end of the abdomen (see figs. 98 and 99), is leathery, sac-like, and devoid of distinct segmentation; in the gravid female shortly before parturition, as represented in fig. 100, it is enormously distended. The wings have a brownish tinge, and the strongly developed veins are crowded together into a small area including and adjacent to the proximal three-fourths of the costal margin; below and beyond the veins the wing-membrane is conspicuously rilled, i.e., thrown into narrow, oblique ridges and furrows. The legs are powerful and adapted to their function of clinging to the hair or feathers of the host, the tarsal claws, which are 
large, strong, and of unusual length, being sharply bent and provided with an accessory tooth at the base. In the flattened head the eyes are wide apart in both sexes, so that the width of the front is of no value for the distinction of males and females; the antennæ, which are concealed in pits, are invisible from above, and so as a rule is the proboscis; the latter, which is curved and extremely slender, is protruded when required for use from between a pair of prominent, downwardly projecting, chitinous blades (the maxillary palpi). Although the sexes (or at least males and non-pregnant females) are closely similar as regards other external characters, the females can usually be distinguished without any great difficulty, owing to the presence at the tip of the abdomen in this sex of a median, tongue-like, chitinous flap on the dorsal side; this flap or lobe is clearly shown in fig. 100, but since it sometimes stands up vertically, close examination may be necessary in order to recognise it in dried specimens. The males sometimes show at the tip of the abdomen a protruding, curved, chitinous spine (part of the genital apparatus). As regards dimensions, the species of Hippobosca vary from a length of 5 or $6 \mathrm{~mm}$. (wing-expanse 14-16 mm.) in the case of $H$. capensis, von Olfers, to $11.5 \mathrm{~mm}$. (wing-expanse $24 \mathrm{~mm}$.) in that of a female $H$. camelina, Leach, containing an adult larva; it should be noted that gravid females are subject to great variations in size owing to the distension of the abdomen produced by the larva.

Owing to the parasitic habits of the genus Hippobosca, the distribution of many of the species, like that of Hippoboscidæ in general, is remarkably extensive, since the flies have often been introduced with one or other of their hosts into new localities by the agency of man. In addition to the three species represented on Plate XIII., three others are also found.in the Ethiopian Region; of these, the European Hippobosca equina, Linn., which is a parasite of horses* and has been met with in Senegal and Cape Colony as well as in Egypt, has doubtless been introduced with its host, as has happened in other parts of the world. Hippobosca capensis, von Olfers (syn. $H$. francilloni, Leach), which is the smallest species of this genus and was originally described from a specimen from the Cape of Good

* H. equina also occurs locally on cattle. 
Hope, is known to occur in Egypt, the Anglo-Egyptian Sudan, and the East Africa Protectorate ; it is parasitic on dogs, and is found from South Europe to North China and Japan. Hippobosca camelina, Leach (syn. H. dromedarina, Speiser), the sixth and largest species, as its name implies infests camels, and its distribution is doubtless co-extensive with that of its host; at any rate in Africa it is known to occur from Somaliland along the North-Eastern and Northern African littoral at least as far as Algeria, and a specimen has even been received from Northern Nigeria, taken in the district east of Illela, in 1904 (Captain P. S. Lelean, R.A.M.C.). In addition to African examples of $H$. camelina, others have been received from Arabia, Sinai, Syria, Asia Minor, and Southern Afghanistan.

In the case of species parasitic upon horses and cattle, the flies congregate chiefly on parts where the skin is thinnest, i.e., beneath the tail, on the perinæum, and on the inner surface of the thighs. The bite does not appear to cause pain, and horses have been seen standing perfectly quietly with as many as twenty or thirty Hippobosca maculata crawling between their thighs, in addition to other specimens which had the proboscis buried in the skin; on the other hand sensitive horses are sometimes driven almost frantic by the irritation caused by a single one of these flies crawling over them. The toothed claws enable the fly to cling so tightly to the hair that it is impossible for an animal to dislodge it by a brush from its tail, and the quick and somewhat crab-like movements of the insect, which when disturbed usually runs sideways, tickle the host and are exceedingly irritating to a nervous animal.

Reproduction in the genus Hippobosca is of the

Life-history. normal Hippoboscid type, the female producing but a single adult larva at a birth, and the larva being retained until mature within the uterus or dilated oviduct, where it is nourished by the secretion of a pair of much ramified glands. On extrusion the larva is a white or pale yellowish, ovoid or flattened globular body, with a small depression at the oral pole and a conspicuous black cap at the opposite one, but without showing any ordinary traces of segmentation. On the dorsal and ventral surfaces, however, a longitudinal row of six punctures on 
each side near the lateral margin supplies an indication of mctameric division. Just in front of the foremost pair of punctures the larva is encircled by a narrow groove, with which is connected a longitudinal groove, which runs along each side and crosses the oral depression. These grooves mark the limits of the cap, that in the puparium splits off to permit the escape of the imago. On the dorsal surface there is a pair of somewhat transversely elongate depressions or punctures about midway betwcen the encircling groove and the oral depression. On the ventral surface, immediately in front of the black cap, the anus may be seen in the shape of a small, dark, median pore. The posterior stigmata are situate in the centre of the black cap. In the case of a dead and dried female containing an adult or a nearly adult larva, which appears to occupy the whole of the distended abdomen, the black cap of the larva can be seen at the hinder extremity of the abdomen, within the gaping orifice of the vagina. After the larva is extruded the black cap speedily becomes almost obliterated by the general chitinisation of the integument to form the puparium or pupa-case, which is of a clove-brown or nearly black colour, and closely resembles the ripe secd of a leguminous plant. The imago subsequently makes its escape from the puparium by splitting off the above-mentioned cap at the cephalic pole. Notes on the larva and puparium of $H$. maculata, Leach, and on the puparium of $H$. rufipes, von Olfers, will be found on pp. 175, 176, and 178 .

The extrusion of Hippobosca larvæ under natural conditions has not been observed,* so that it is at present impossible to say whether it takes place on the host, or whether the parturient females leave the latter and alight for the purpose on some suitable spot on the ground. It is obvious that if the larva be simply dropped whilc the fly clings to the host, it must be exposed to the risk of being trodden under foot by the latter or otherwise destroyed. The National Collection contains two puparia of $H$. camelina, Leach, which werc

\footnotetext{
* When pregnant females belonging to this genus and containing immature larva are captured alive, they frequently abort, as do Tsetse-flies under similar conditions; the larva deposited in this way are, of course, incapable of further developinent or of turning into pupæ.
} 
found by the Rev. A. E. Eaton at Biskra, Algeria, on March 3rd, 1894, " by digging " at the roots of Euphorbia guyoniana; from one of these puparia the perfect insect emerged on May 6th, 1894. Since the larvæ of Hippoboscidæ on being extruded are incapable of movement, the fact that these puparia were obtained "by digging" would seem to indicate something more than that the larvæ had merely fallen from a host which had happened to be standing or lying on the spot, and would apparently suggest that they had been deposited where the puparia were found, by females which had intentionally crawled into cracks in the soil in order to consign their offspring to a safe resting place.

As will be seen below, Hippobosca rufipes, von

Hippobosca Olfers, and $H$. maculata, Leach, have been and Disease. experimentally shown to be capable of transmitting Trypanosoma theileri, Laveran, which is the cause of gall- or bile-sickness among cattle in the Transvaal, while the former species has been thought to be responsible for the dissemination of a local form of anthrax among horses in parts of Griqualand West. It is not likely that under ordinary circumstances these flies are directly inimical to man, since although $H$. maculata is said sometimes to bite human beings, such an occurrence is undoubtedly exceptional.

Hippobosca struthionis, Janson.

In the late Miss Eleanor A. Ormerod's "Notes and Descriptions of a Few Injurious Farm and Fruit Insects of South Africa," p. 56, fig. 23 (London : Simpkin, Marshall and Co., 1889).

Plate XIII., Fig. 98.

This is a species of peculiar interest, since, instead of being a mammal parasite like the other members of the genus Hippobosca, it infests the ostrich (Struthio australis, Gurney).* The localities,

* It is true that the typical specimen of Hippobosca rufipes, v. Olfers, is said to have been taken on an ostrich; but, as will be seen below (p. 177), this was probably accidental. 
etc., of the nine specimens in the Museum Collection, all of which are from Cape Colony or the East Africa Protectorate, are as follows.-Cape Colony: Mount Stewart, May, 1886,- the type of the species $(J . H$. Cawood,-received in exchange from O. E. Janson); Deelfontein, 1902 (presented by Colonel A. T. Sloggett, C.M.G., R.A.M.C.) ; Phillipsdale, Worcester, November 20th, 1907 (T. B. Goodall). East Africa Protectorate: Makumbu, between February 6th and March 8th, and Athi-ya-Mawe, between May 6th and 19th, 1899 (C. S. Betton); Ukambu, Machakos, 1900 (Captain Richard Crawshay). It should be noted that the figure shows the wings in the resting position, and that the markings on the scutellum are represented as seen in East African specimens; in the examples from Cape Colony at present available for comparison the lateral scutellar spots are scarcely visible.

According to a correspondent quoted by the late Miss Ormerod,* it was stated by the collector of the type of the species that at Mount Stewart, Cape Colony, in May, 1886, these flies were in "thousands on the ostriches, that they irritated the birds so that half of their time was taken up in pecking at the flies, and that, judging from the increase in the last two years, if something was not done to destroy them, the feathers would not be worth sending to market, and the writer believed that in time they would destroy the birds." Whether the treatment adopted, which consisted in dressing the infested birds with sulphur, was successful it is impossible to say, but in 1905 it was stated by Mr. C. P. Lounsbury, Government Entomologist, Cape Colony, that Hippobosca struthionis "leads to serious deterioration of the feathers." $\dagger$

With reference to the specimens taken by him at Phillipsdale, Worcester, Cape Colony, Mr. T. B. Goodall has kindly supplied the following note :- "From an ostrich six months old; found under the wings and tail, where the skin is bare and thin. The fiies run over the body and fly just like $H$. equina, L. One specimen on being disturbed left the bird and was caught on the writer's coat."

* Cf. E. A. Ormerod, op. cit., p. 58.

$" \dagger C f$. C. P. Lounsbury, in "Science in South Africa" (T. Maskew Miller: Cape Town, Pretoria and Bulawayo, 1905), p. 372. 
Hippobosca maculata, Leach.

"On the Genera and Species of Eproboscideous Insects," p. 8, Pl. II., figs. 11-13 (Edinburgh : 1817): Memoirs of the Wernerian Natural History Society, Vol. II., p. 553, Tab. XXVI., figs. 11-13 (Edinburgh : 1818).

\section{Plate XIII., FIg. 99.*}

Hippobosca maculata, Leach, a widely distributed species which is common in West Africa as well as in many parts of Southern Asia and elsewhere, doubtless owes its extensive range to its having been imported into different countries with horses and cattle, on which it is parasitic. The following are the localities, etc., of the African specimens in the National Collection.-Gold Coast, Northern Territories: Gambaga, March 9th, 1904, "common on horses" (Captain J. O'Kinealy). Ashanti : Kumasi, April 8th, 1905, "on cattle" (Lieut.-Colonel G. M. Giles, late I.M.S.) ; Obuasi, February 19th and 21st, April 16th, and August 8th, 1906, and May 25th, 1907, "on cattle" (Dr.W.M. Graham, W.A.M.S.) ; North-West Ashanti, September, 1906 (Dr. R. Cope, W.A.M.S.). Northern Nigeria: Kontagora, October 15th, 1903, "terribly annoying to horses" (Surgeon-Major J. J. V. A. C. Raye, W.A.M.S.) ; Yola, Benue River, March 29th, 1905, and Bena, Kontagora Province, June 12th, 1906 (W. F. Gowers); Zungeru, July 18th, 1905 (Dr. J.M.Dalziel, W.A.M.S.) ; Akwatcha, Bassa Province, January 1st, 1907, "on horses and cattle" (Dr. G. J. Pirie) ; Keffi, Nassarawa Province, April 29th, 1907 (Dr. R. F. Williams, W.A.M.S.); Benue River, August, 1907 (J. Brand) ; South Bornu, September, 1907 (Dr. H. A. Foy, W.A.M.S.). Southern Nigeria: Abutshi, R. Niger, 1903 (A. Braham). Egypt, "beyond the Cataracts," 1846 (C. Lamb). Abyssinia: Taddocha Mullka, February 8th, 1902 (E. Degen); Esser Gota, August 9th, and base of Mt. Fantali, August 23rd, 1908 (Dr. R. E. Drake-Brockman). Somaliland

* This figure, like that of the foregoing species, represents a fly in the resting position. 
Protectorate : Zaila, May 25th, 1895 (Captain-now Lieut.-ColonelC. G.Nurse). Portugucse East Africa: Incanine, Lorenzo Marques, December 11th, 1906, "on Kaffir blanket," Decembcr 16th, 1906, "on old Kaffir woman"; Mavota, Lorenzo Marques, December 13th, 1906, "on Kaffir child"; and Inyack Island, Delagoa Bay, February 15th, 1907, "on native's clothes" (F. D. McMillan).

As regards the occurrence of Hippobosca maculata beyond the confines of Africa, it may be mentioned that the Museum possesses examples from:-the Peninsula of Sinai, Aden, Madagascar, Mauritius, the Seychelle Is., and a number of localities in India and Ceylon. The specimens from India include the type of the species, which is from Bengal.*

With reference to Hippobosca maculata in Ashanti, Dr. W. M. Graham writest:- "Specimens of this species were taken upon cattle all over Ashanti, and, when in the Northern Territories some years ago, I found the fly widely distributed. Though living in large numbers upon oxen they do not appear to cause the cattle great annoyance. They frequently follow human beings along the roads, perching upon the back, or legs, or endeavouring to get into the hair of the head. On a couple of occasions flies flew into my bungalow and took refuge in my hair."

There is evidence that Hippobosca maculata may occasionally bite man. Thus Dr. R. Cope, when forwarding for identification the specimen from the North-West District of Ashanti referred to above, stated that the fly (a female, taken in the verandah of a house) had bitten him on the forearm near the elbow before he caught it; and the author has been assured by Dr. A. M. Elliot that at Bangalore, in India, he has frequently induced $H$. maculata to bite him by placing it on his arm. Again, Major F. Smith, D.S.O., R.A.M.C., when sending a specimen of this fly from Benares, stated that it "bites horses and sometimes men." In a subsequent letter, however, dated "Benares, June 18th, 1907," Major Smith wrote :-

\footnotetext{
* Leach, who was evidently unaware that $H$. maculata occurs in Africa, writos (loc. cit.):- "Habitat in India Orientali haud infrequens."

† "Report by Dr. W. M. Graham upon Entomological Observations made in Southern and Central Ashanti, 1907," p. 14 (issued by the Colonial Office, 1909).
} 
"It would be as well not to take too much notice of my statement that Hippobosca maculata 'sometimes bites men.' The natives are not agreed; some flatly deny that it ever bites men, others say it does sometimes. But it will be best not to believe until some European says that he has seen it biting man."

Two females of this species taken by Captain Life-history J. O'Kinealy at Gambaga (vide supra) gave birth of Hippobosca to larvæ about an hour after being captured. As maculata. described by Captain O'Kinealy in a letter written the same day:- "Within a short time of being deposited the larvæ were of a pale yellowish colour, with a black cap at one end and two minute dots or holes at the other; in the course of four or five hours, however, they turned black all over " (i.e., changed into pupæ). The pupæ thus obtained were forwarded to the Museum by Captain O'Kinealy with the flies, and the following notes are the result of an examination of the larger of the two specimens.

The puparium or pupa-case of Hippobosca maculata is a dull black capsule, roughly rounded-ovate in shape when viewed from the dorsal surface, and convex above, with the posterior extremity truncate and the anterior pole flattened and depressed; the ventral side is also somewhat flattened. The entire surface is finely punctate, though the punctures are much coarser than in the case of the puparium of $H$. camelina, Leach, which is very much larger. The puparium examined is $4.4 \mathrm{~mm}$. in length, by $3.8 \mathrm{~mm}$. in breadth at the widest part, and $2 \mathrm{~mm}$. in breadth at the posterior extremity. Rather less than $1 \mathrm{~mm}$. in front of the posterior extremity the pupacase is encircled by a shallow groove, marking off a terminal area (corresponding to the "black cap" of the larva), which, by means of a $\wedge$-shaped groove of little depth is indistinctly divided into three sections. At the apex of the median triangular section can be seen the vestiges of the posterior stigmata of the larva; the three sections, with the exception of a narrow vertical stripe in the centre of the triangular one, are covered with low tubercles. On the ventral side in the median line, immediately in front of the groove marking off the terminal area, is a small pore representing 
the larval anus. At a distance of $1.5 \mathrm{~mm}$. behind the anterior and wider extremity the puparium is encircled by a second shallow and narrow groove, marking the limits of the cap that is split off when the imago makes its escape. On each side about $0.5 \mathrm{~mm}$. from the lateral margin, on both dorsal and ventral surfaces, commencing immediately behind this groove and extending back to a point about $0.8 \mathrm{~mm}$. from the posterior groove, is a series of sharply marked punctures; those in each series on the ventral surface are connected by a deep furrow, which is less distinct on the dorsal side. In the specimen examined there appear to be seven punctures in each dorsal row, and six in each row on the ventral surface. Since this puparium is that of a larva deposited by a captive fly its dimensions are possibly subnormal ; the second puparium forwarded by Captain O'Kinealy is very small and obviously immature.

\section{Hippobosca} maculata

as a

According to Laveran,* Dr. Theiler has shown by experiment at Pretoria that Hippobosca maculata, Leach, and $H$. rufipes, v. Olfers (see Disease-carrier. below), are capable of transmitting Trypanosoma theileri, Laveran, which is the cause of Gallziekte (gall- or bile-sickness) among cattle in the Transvaal.

\section{Hippobosca rufipes, von Olfers.}

De Vegetativis et Animatis Corporibus in Corporibus Animatis Reperiundis Commentarius. Pars I. P. 101 (Berolini : In Taberna Libraria Maureriana, 1816.). $\dagger$

\section{Plate XIII., Fig. 100.}

The markings on the scutellum render it easy to recognise this species, which is a common parasite of horses in South Africa. In

* Comptes Rendus Hebdomadaires des Séances et Mémoires de la Société de Biologie, Année 1903, pp. 242-243 (1903).

$\ddagger$ This figure has been drawn from a gravid female,-hence the large size of the abdomen.

† As given by Hagen ("Bibliotheca Entomologica," Bd. II., p. 20 (Leipzig: Verlag von Wilhelm Engelmann, 1863)) the title of this work is "De vegetativis et 
addition to those from the Cape region, the Museum also possesses specimens from Angola and the Congo, but it is possible that these had been imported with horses or mules. The localities, etc., of the specimens in the Museum Collection are as follows.-Cape Colony: Colesberg, 1860, and Cape Town, 1864 (R. Trimen); Burghersdorp, 1865 (Dr. Kannemeyer); King Williamstown District, 1899 (Miss Barrett); Deelfontein, 1902 (presented by Colonel A. T. Sloggett, C.M.G., R.A.M.C.); Griqualand West, 1902, "from horse" (G. E. H. Barrett-Hamilton); Bechuanaland, 1907 (F. W. Jones). Natal: Durban, 1853 (purchased from Stevens); Estcourt, January, 1897 (G. A. K. Marshall). Basutoland: Maseru, January 13th and May 25th, 1902 (Captain Richard Crawshay), and 1907 (L. Wroughton). Orange River Colony : Bloemfontein, 1898 (- Wilman). Transvaal : Pretoria, 1904 (Dr. A. Theiler, C.M.G.). Southern Rhodesia: Selukwe, February, 1908 (E. C. Chubb) ; exact locality uncertain, 1908, "brought up to Rhodesia on horses from the Orange River Colony" (Ll. E. W. Bevan). Angola: Bembe Mines, Lat. $7^{\circ} 22^{\prime}$ S., 1860 (J. J. Monteiro). "Congo," 1843 (Surgeon Andrew Curror, R.N., H.M.S. Waterwitch).

According to von Olfers, $\dagger$ the type of Hippobosca rufipes was taken by Lichtenstein on an ostrich (Struthio australis, Gurney) at the Cape of Good Hope, but the describer of the species very reasonably suggests that the fly may have come from a quagga (Equus quagga, Boddaert), since in the early decades of last century quaggas, which were then present in enormous numbers on the Karroo, were very frequently found mingling with the flocks of ostriches. As additional evidence that $H$. rufipes sometimes strays

animatis corporibus in corpore animato reperiundis, Pars I." Hagen also gives the place and date of publication as "Goettingæ, 1815." In none of the catalogues that I have been able to consult, however, is there any mention of an 1815 (Göttingen) edition; the 1816 (Berlin) edition alone is mentioned, and the title quoted is the same as that given above, which is taken from the Museum copy, formerly in the library of Sir Joseph Banks. Wiedemann "Aussereuropäische zweiflügelige Insekten," II., p. 604, note, 1830) quotes the 1816 edition. - Since the foregoing was written, I have received a most courteous letter from Dr. F. Reicke, of the Königliche Universitäts-Bibliothek, Göttingen, informing me, in reply to an enquiry, that a copy of the 1816 edition of Von Olfers's work is the only one contained in that institution; and that, in spite of an exhaustive search, he has been unable to discover any evidence of the existence of an 1815 (Göttingen) edition.

† op. et loc. cit. 
away from its true host, it may be mentioned that Mr. W. L. Distant states that, during his residence in the Transvaal, this fly often attached itself to his neck.*

A puparium of this species from Pretoria (Dr. A.Theiler, C.M.G.) is $5.6 \mathrm{~mm}$. in length by $4.8 \mathrm{~mm}$. in breadth at the widest part, and is similar in shape to the puparium of $H$. maculata, Leach, already described, though the "black cap" at the posterior extremity is somewhat more tumid on each side. The colour, with the exception of the black cap, is dark seal-brown. In front of the black cap the whole surface is very finely punctate; the lateral and median-ventral divisions of the black cap show very indistinct tubercles. The posterior edge of the cephalic cap (that splits off to permit the escape of the imago) is faintly marked by a darker line, but there is no distinct groove. The longitudinal row of punctures on each side above and below, near the lateral margin, are less sharply marked than in the puparium of $H$. maculata described above, and the punctures (six in each row) are not connected by a furrow.

As already stated, according to Laveran, $\dagger$ it has Hippobosca been shown experimentally by Dr. Theiler at rufipes as a Pretoria that Hippobosca rufipes (with $H$. Disease-carrier. maculata, Leach) is capable of transmitting Trypanosoma theileri, Laveran, the cause of Gallziekte (gall- or bile-sickness) among cattle in the Transvaal. According to Mr. D. Hutcheon, M.R.C.V.S., Chief Veterinary Surgeon, Cape Colony, a local form of anthrax in horses in parts of Griqualand West, which is very common and characterised by circumscribed cutaneous swellings, is "most probably" due to infection caused by Hippobosca rufipes. $\ddagger$

* Cf. W. L. Distant, "A Naturalist in the Transvaal" (London: R. H. Porter, 1892), p. 244.

† Comptes Rendus Hebdomadaires des Séances et Mémoires de la Société de Biologie, Année 1903, pp. 242-243 (1903).

$\ddagger C f$. D. Hutcheon, in "Science in South Africa" (T. Maskew Miller : Cape Town, Pretoria and Bulawayo, 1905), p. 348. 
CHAPTER VIII.

Lists of African Blood-Sucking Flies at present known (exclusive of Mosquitoes and Tsetse-Flies), arranged UNDER Countries.

The Species figured are distinguished by an asterisk (*).

For the sake of convenience the following grouping and sequence have been adopted :-

I.

\section{BRITISH COLONIES AND PROTECTORATES.}

West Africa .. Gambia.

Sierra Leone and Sierra Leone Protectorate.

Gold Coast.

Ashanti.

Northern Nigeria.

Southern Nigeria.

East Africa .. (Somaliland Protectorate-see Somaliland).*

East Africa Protectorate.

Zanzibar Protectorate (Zanzibar and Pemba Island only).

Gentral Africa .. Uganda Protectorate.

Nyasaland Protectorate.

South Africa .. North-Eastern Rhodesia.

North-Western Rhodesia.

Southern Rhodesia.

Transvaal.

Orange River Colony.

Natal (including Zululand).

Cape Colony.

* Since it has been found impracticable to separate species occurring within the limits of the British and Italian spheres of influence respectively, Somaliland for the purposes of this chapter has been treated as an independent country. 
II.

FRENCH COLONIES AND PROTECTORATES.

Mauritania.

Senegal.

French Sudan (Senegambia-Niger).

French Guinea.

French Ivory Coast (Grand Bassam and Assinie).

French Congo and Gaboon.

French Somaliland.

III.

GERMAN COLONIES.

Togoland.

Cameroon.

German South-West Africa.

German East Africa.

IV.

ITALIAN COLONIES.

Eritræa.

(Italian Somaliland-see Somaliland).*

V.

\section{PORTUGUESE COLONIES AND DEPENDENCIES.}

Prince's Island.

Cabinda.

Angola.

Portuguese East Africa.

* Since it has been found impracticable to separate species occurring within the limits of the British and Italian spheres of influence respectively, Somaliland for the purposes of this chapter has been treated as an independent country. 
VI.

ABYSSINIA.

VII.

ANGLO-EGYPTIAN SUDAN.

\author{
VIII. \\ CONGO FREE STATE.
}

IX.

EGYPT.

$\mathrm{X}$.

LIBERIA.

XI.

SOMALILAND.

I.

BRITISH COLONIES AND PROTECTORATES.

WEST AFRICA.

Gambia.

TABANID $\ldots \quad$.. Tabanus albipalpus, Walk.

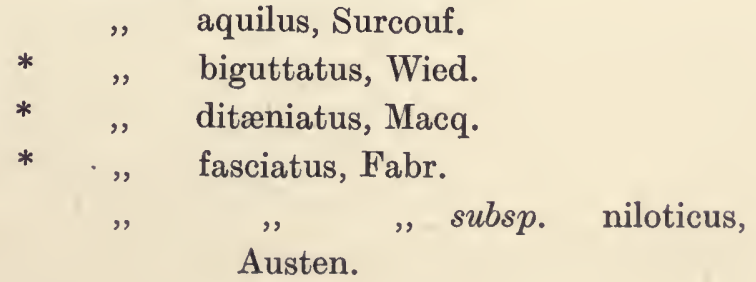


182

* Tabanus gratus, Lw.

* , , laverani, Surcouf.

* " par, Walk.

* , socialis, Walk.

, sufis, Jaenn.

* , , tæniola, Pal. de Beauv.

* , variatus, Walk.

Muscide $\ldots \quad \ldots \quad *$ Stomoxys calcitrans, L.

* , nigra, Macq.

Lyperosia minuta, Bezzi.

Sierra Leone and Sierra Leone Protectorate.

Srmulmdж. . . $\quad$ Simulium sp. nov.

Tabanid $\ldots \quad \ldots \quad *$ Chrysops longicornis, Macq.

* Tabanus brumpti, Surcouf.

* ", fasciatus, Fabr.

* " $\quad$ kingsleyi, Ricardo.

* " laverani, Surcouf.

* „, obscurissimus, Ricardo.

* $\quad$ par, Walk.

* „, ruficrus, Pal. de Beauv.

* , thoracinus, Pal. de Beauv.

* " pluto, Walk.

* $\quad$ " secedens, Walk.

* $\quad$, socialis, Walk.

" sp. nov., allied to T. congoiensis, Ricardo.

* „ „ tæniola, Pal. de Beauv.

Thaumastocera akwa, Grünb.

Hæmatopota lacessens, Austen.

Hippocentrum trimaculatum, Newstead.

Muscid $\approx$. . . * Stomoxys nigra, Macq. 
Gold Const.

TABANID $\ldots \quad$.. Tabanus biguttatus, Wied., form croceus, Surcouf.

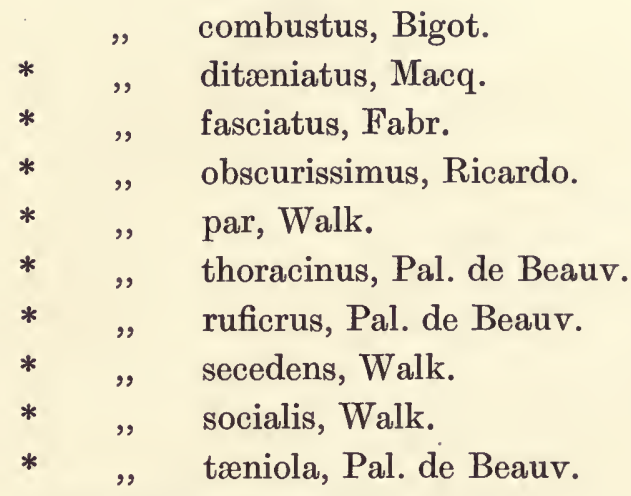

Thaumastocera akwa, Grünb.

* Hæmatopota torquens, Austen.

Hippocentrum trimaculatum, Newstead.

Muscid $2 \quad \ldots \quad \ldots \quad *$ Stomoxys calcitrans, $\mathbf{L}$.

* " nigra, Macq.

Hippoвоscid жа . * Hippobosca maculata, Leach.

Ashanti.

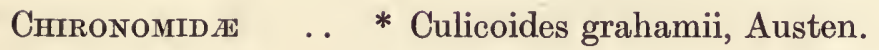

Psychodid $\quad$. $\quad *$ Phlebotomus duboscqi, Neveu-Lemaire.

TABANid A. . . . * Chrysops longicornis, Macq.

* $\quad$, dimidiata, v. d. Wulp.

* " distinctipennis, Austen.

Tabanus (?) besti, Surcouf.

* " biguttatus, Wied.

", combustus, Big.

* $\quad$, fasciatus, Fabr.

* ", marmoratus, Surcouf.

* $\quad$, secedens, Walk.

* $\quad$ " thoracinus, Pal. de Beauv. 
184

Thaumastocera akwa, Grünb.

Hæmatopota cordigera, Big.

* , grahamii, Austen.

Hippocentrum trimaculatum, Newstead.

Muscid $\ldots$. . $\quad *$ Stomoxys calcitrans, L.

", brunnipes, Grünb. (sellata,

Grünb.).

* , inornata, Grünb.

* $\quad$,. nigra, Macq.

* , omega, Newstead.

Hippoвoscid ж . * Hippobosca maculata, Leach.

Northern Nigeria.

Tabanid $\ldots \quad \ldots \quad *$ Chrysops distinctipennis, Austen.

* , $\quad$ silacea, Austen.

"sp. nov.

Rhinomyza sp. nov.

* Pangonia rüppellii, Jaenn.

" sp. - ? nov., near P. rüppellii, Jaenn.

Tabanus albipalpus, Walk.

* , biguttatus, Wied.

, " , $\quad$ form croceus,

Surcouf.

* , ditæniatus, Macq.

* , fasciatus, Fabr.

Austen.

uscipes, Ricardo.

* $\quad$, latipes, Macq.

, $\quad$ sp. nov., allied to T. latipes, Macq.

* , laverani, Surcouf.

* , par, Walk.

* $\quad$, thoracinus, Pal. de Beauv. 
* Tabanus pluto, Wied.

* „ $\quad$ ruficrus, Pal. de Beauv.

* $\quad$ " secedens, Walk.

, subangustus, Ricardo.

, sufis, Jaenn.

* $\quad$, tæniola, Pal. de Beauv.

* $\quad$ " variatus, Walk.

" williamsii, Austen.

* Hæmatopota bullatifrons, Austen.

, $\quad$ cordigera, Big.

* $\quad$, decora, Walk.

" gracilis, Austen.

* $\quad, \quad$ lacessens, Austen.

* $\quad$ pallidipennis, Austen.

pertinens, Austen.

pulchrithorax, Austen.

puniens, Austen.

tenuicrus, Austen.

sp. nov.-near H. tenuicrus,

Austen.

Hippocentrum trimaculatum, Newstead.

* versicolor, Austen.

Muscid $\ldots$. . Stomoxys brunnipes, Grünb.

* $\quad, \quad$ calcitrans, L.

, inornata, Grünb.

* $\quad$ nigra, Macq.

Lyperosia minuta, Bezzi (? syn. longipalpis, Roubaud).

НтрровоSCID ж .. Hippobosca camelina, Leach.

* , maculata, Leach.

Soutirern Nigeria.

Chironomid же .. * Culicoides grahamii, Austen.

Psychodid ж $\quad$.. * Phlebotomus duboscqi, Neveu-Lemaire. 
TABANID $\ldots \quad \ldots *$ * Chrysops dimidiata, v. d. Wulp.

* , $\quad$ silacea, Austen.

Tabanus biguttatus, Wied., form croceus, Surcouf.

* $\quad$ billingtoni, Newstead.

" combustus, Big.

* " fasciatus, Fabr.

" obscurefumatus, Surcouf.

" obscurehirtus, Ricardo.

* $\quad$ " ruficrus, Pal. de Beauv.

* $\quad$ " secedens, Walk.

" subangustus, Ricardo.

* $\quad$ " tæniola, Pal. de Beauv.

* „, thoracinus, Pal. de Beauv.

Thaumastocera akwa, Grünb.

Hæmatopota pulchrithorax, Austen.

Hippocentrum trimaculatum, Newstead.

* versicolor, Austen.

Muscide $\ldots \quad \ldots \quad *$ Stomoxys nigra, Macq.

Нippoвоsсid ж $\ldots *$ * Hippobosca maculata, Leach.

EAST AFRICA.

East Africa Protectorate.

Chironomide $\quad$. * Culicoides milnei, Austen.

Tabanid . . $_{\text {T. . . }} *$ Pangonia rüppellii, Jaenn.

(Diatomineura)distincta, Ricardo.

* Tabanus africanus, Gray.

* " biguttatus, Wied.

* " $\quad$ conspicuus, Ricardo.

* " ditæniatus, Macq.

" morsitans, Ricardo.

" pallidifacies, Surcouf.

* " par, Walk.

* $\quad$ "rothschildi, Surcouf. 
* Tabanus tæniola, Pal. de Beauv.

,, velutinus, Surcouf.

Hæmatopota longa, Ricardo.

$$
\begin{array}{lll} 
& , & \text { distincta, Ricardo. } \\
\text { * } \quad \text { mactans, Austen. } & \text { nigrescens, Ricardo. }
\end{array}
$$

Muscid $A$

. * Stomoxys calcitrans, L.

* , nigra, Macq.

, tæniata, Big.

Нrрровоscid ж . $\quad$ Hippobosca capensis, v. Olf.

* $\quad$, struthionis, Janson.

Echestypus sepiaceus, Speiser.

Zanzibar Protectorate (Zanzibar and Pemba Island only).

Tabanid $\ldots$. . . Parhæmatopota cognata, Grünb.

Muscid $\ldots$. . * * Stomoxys calcitrans, L.

* $\quad$ nigra, Macq.

Нтрровоsсid ж .. Hippobosca capensis, v. Olf.

\section{CENTRAL AFRICA.}

Uganda Protectorate.

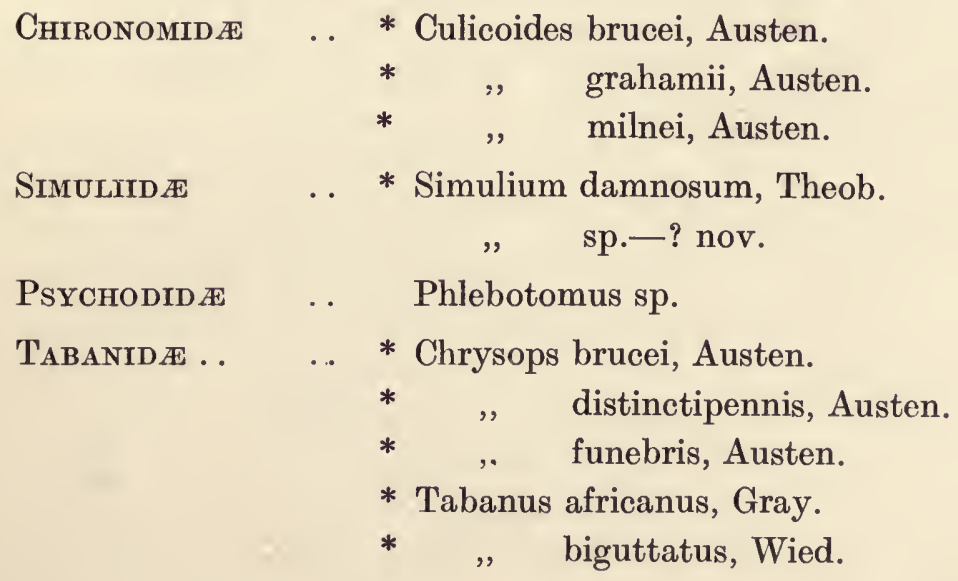


188

* Tabanus brucei, Ricardo.

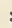

" brumpti, Surcouf

* " denshamii, Austen.

* " $\quad$ sp.—? nov.

* „ fasciatus, Fabr.

" $\quad$ "subsp. niloticus,

Austen.

" fuscomarginatus, Ricardo.

* $\quad$ insignis, Lw.

* $\quad$ " par, Walk.

* " thoracinus, Pal. de Beauv.

* , pluto, Walk.

* $\quad$ " ruwenzorii, Ricardo.

* , $\quad$ secedens, Walk.

* " tæniola, Pal. de Beauv.

* „ „ variabilis, Lw.

* , variatus, Walk.

* Hæmatopota brucei, Austen.

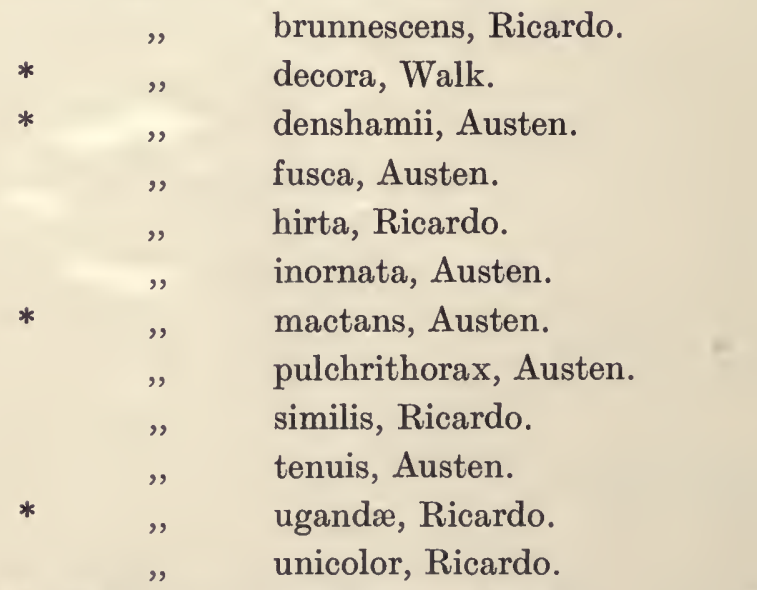

* Hippocentrum versicolor, Austen.

Muscid $\quad$.. . . Stomoxys brunnipes, Grünb.

* $\quad$ calcitrans, L.

* \# nigra, Macq.

* Lyperosia punctigera, Austen. 
Nyasaland Protectorate.

Chironomide $\quad$. $\quad$ Culicoides sp. nov.

Srmulitd .. $\quad$.. Simulium sp.—? nov.

Tabanida .. . . Cadicera nigrescens, Ricardo.

Pangonia compacta, subsp. centralis,

Austen.

" fodiens, Austen.

" oldii, Austen.

, (Diatomineura) obscura, Ricardo.

* Tabanus africanus, Gray.

* , biguttatus, Wied.

* $\quad$, claritibialis, Ricardo.

* , ditæniatus, Macq.

* $\quad$ fraternus, Macq.

", fuscipes, Ricardo.

", grandissimus, Ricardo.

* ", gratus, Lw.

* , maculatissimus, Macq.

* , nigrostriatus, Ricardo.

* , , nyasæ, Ricardo.

* " par, Walk.

* „, ruficrus, Pal. de Beauv.

* ", sharpei, Austen.

* , , tæniola, Pal. de Beauv.

,, (?) unilineatus, Lw.

* , variatus, Walk.

Hæmatopota brunnescens, Ricardo.

$\begin{array}{lll}* & \text {, } & \text { decora, Walk. } \\ & , & \text { distincta, Ricardo. } \\ & , & \text { furtiva, Austen. } \\ & , & \text { insatiabilis, Austen. } \\ & , & \text { insidiatrix, Austen. } \\ & \text { * } & \text { longa, Ricardo. } \\ & \text { ", } & \text { mactans, Austen. }\end{array}$


Hæmatopota malefica, Austen.

$\begin{array}{ll}, & \text { nocens, Austen. } \\ , & \text { nociva, Austen. } \\ , & \text { noxialis, Austen. } \\ , & \text { pertinens, Austen. } \\ , & \text { pulchrithorax, Austen. } \\ , & \text { stimulans, Austen. }\end{array}$

Muscid a . . . * * Stomoxys nigra, Macq.

Stygeromyia sanguinaria, Austen.

SOUTH AFRICA.

North-Eastern Rhodesia.

Tabanide .. . . * Tabanus denshamii, Austen.

, distinctus, Ricardo.

, grandissimus, Ricardo.

* , par, Walk.

* „ thoracinus, Pal. de Beauv.

* , septempunctatus, Ricardo.

* , , ustus, Walk.

Hæmatopota sanguinaria, Austen.

North-Western Rhodesia.

Tabanida .. . . Tabanus coniformis, Ricardo.

, disjunctus, Ricardo.

, obscuripes, Ricardo.

", ? sp.nov.-near T. quadrisignatus,

Ricardo.

, , , , near T. ustus, Walk.

", sp. nov.

* , variatus, Walk. 
Hæmatopota copemanii, Austen.

$$
\begin{array}{lll} 
& , & \text { divisapex, Austen. } \\
& \text { hirsutitarsus, Austen. } \\
& \text { * } & \text { insidiatrix, Austen. } \\
& \text { mactans, Austen. } \\
& \text { pertinens, Austen. } \\
& \text { sanguinaria, Austen. } \\
& \text { sp. nov. }
\end{array}
$$

Southern Rhodesia.

Tabanid .. . . Chrysops fusca, Ricardo.

" fuscipennis, Ricardo.

* $\quad$, stigmaticalis, Lw.

Hinea flavipes, Adams.

* Rhinomyza denticornis, Wied.

* Pangonia compacta, Austen.

Tabanus fuscipes, Ricardo.

* ", nyasæ, Ricardo.

* $\quad$ " septempunctatus, Ricardo.

* $\quad$, socialis, Walk.

* „, tæniola, Pal. de Beauv.

Hæmatopota brunnipennis, Ricardo.

,$\quad$ insidiatrix, Austen.
,$\quad$ pertinens, Austen.

Нippoвoscid ж .. Hippobosca rufipes, v. Olf.

Transvaal.

TABanid $\ldots \quad \ldots \quad *$ Chrysops stigmaticalis, Lw.

* Rhinomyza denticornis, Wied.

Cadicera brevis, Lw.

* ", rubramarginata, Macq.

Pangonia chrysopila, Macq.

, ramulifera, Lw.

, (Diatomineura) æthiopica, Thunb. 


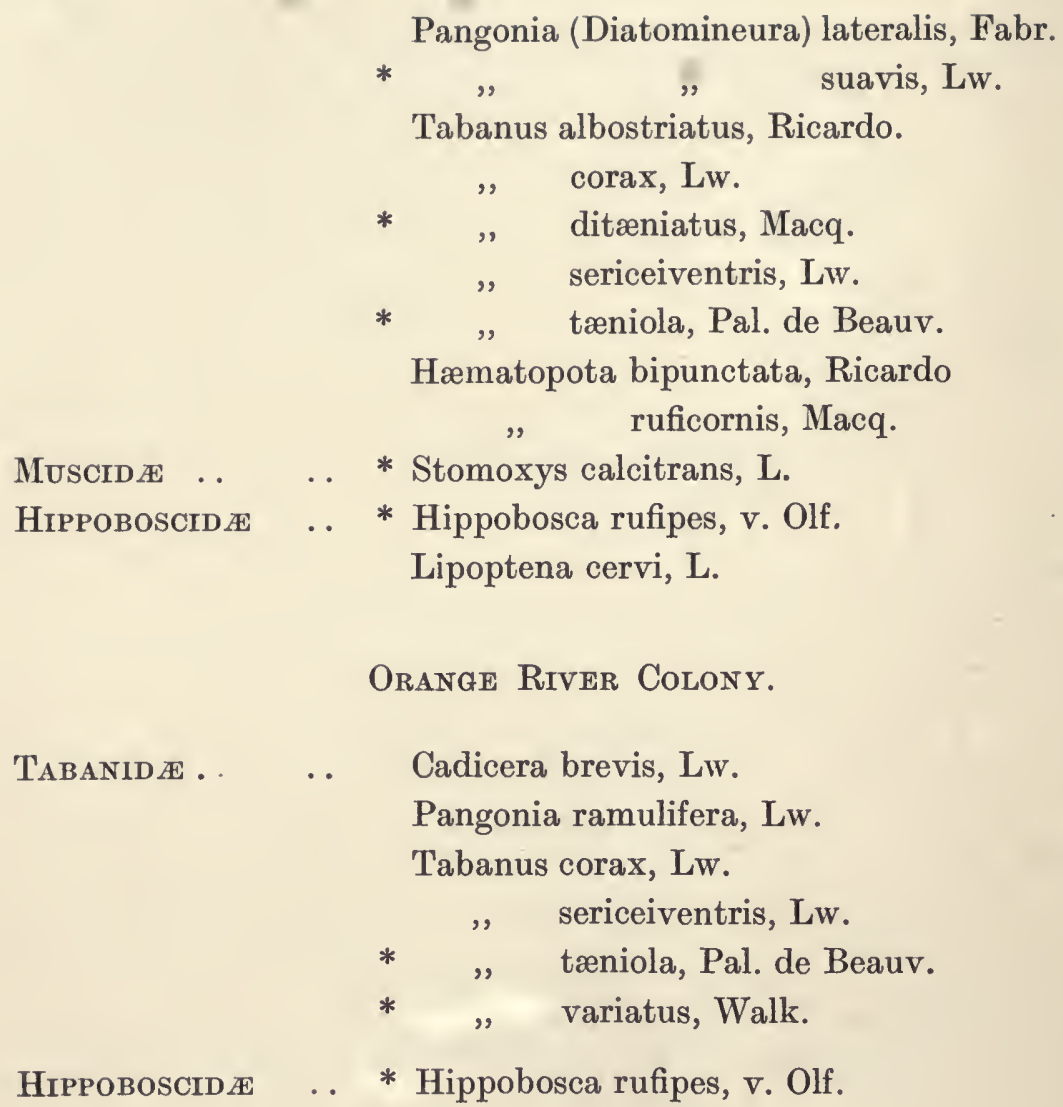

Orange River Colony.

Tabanid . . . Cadicera brevis, Lw.

Pangonia ramulifera, Lw.

Tabanus corax, Lw.

* „ tæniola, Pal. de Beauv.

*,$\quad$ variatus, Walk.

Hippoвoscid ж . * * Hippobosca rufipes, v. Olf.

\section{NATAL.}

Srmulind $\approx$. $\quad$ * Simulium latipes, Mg.

Tabanid . . . . C Chrysops fusca, Ricardo.

, natalis, Macq.

* $\quad$ stigmaticalis, Lw.

* Rhinomyza denticornis, Wied.

Silvius (?) cuncatus, Lw.

, decipiens, Lw.

, glandicolor, Lw.

Pangonia (Diatomineura) æthiopica, Thunb. 
Pangonia (Diatomineura) pallidipennis, Ricardo.

* Tabanus africanus, Gray.

* ", biguttatus, Wied.

* " fraternus, Macq.

" fuscipes, Ricardo.

* ,, insignis, Lw.

* " maculatissimus, Macq.

* " " par, Walk.

* $\quad$, tæniatus, Macq.

* $\quad$ ustus, Walk.

* Hæmatopota decora, Walk. " duplicata, Lw.

" (?) obscura, Lw.

„, pulchrithorax, Austen.

, recurrens, Lw.

" ruficornis, Macq.

MUSCID $\quad \ldots \quad \ldots \quad *$ Stomoxys calcitrans, L.

* $\quad$ nigra, Macq.

" tæniata, Big.

Нippoвоscid ж $\quad . \quad *$ Hippobosca rufipes, v. Olf.

Lipoptena (Ornithobia) capensis, Walk.

Cape Colony.

Simulitd $\quad$.. $\quad$ Simulium nigritarsis, Coquillett.

TABanid $\ldots$.. . . * Chyrsops calida, Walk.

" ciliaris, Walk.

" confluens, Lw. $\dagger$

", lanigera, Lw.

" obliquefasciata, Macq.

* $\quad$, stigmaticalis, Lw.

$\uparrow$ Probably $=$ C. obliquefasciata, Macq. 
Mycteromyia elegans, Big. ensata, Big.

Pronopes nigricans, Lw.

Rhinomyza costata, Lw.

" edentula, Wied.

, pusilla, Schin.

Silvius confluens, Lw.

" cuneatus, Lw.

" decipiens, Lw.

, glandicolor, Lw.

" pertusus, Lw.

* Cadicera chrysostigma, Wied.

„ crassipalpis, Macq.

" hottentota, Lichtenstein.

* , melanopyga, Wied.

* „ rubramarginata, Macq.

* " quinquemaculata, Austen.

* Pangonia adjuncta, Walk.

\begin{tabular}{|c|c|c|}
\hline \multirow{5}{*}{ * } & ", & alboatra, Walk. \\
\hline & ," & angulata, Fabr. \\
\hline & " & atricornis, Wied. \\
\hline & , & bifasciata, Wied. \\
\hline & , & bullata, Wied. \\
\hline & & caffra, Macq. \\
\hline & & charopus, Lichtenstein. \\
\hline & " & chrysopila, Macq. \\
\hline & ", & conjuncta, Walk. \\
\hline & $"$ & flavipes, Macq. \\
\hline \multirow{4}{*}{$*$} & , & gulosa, Wied. \\
\hline & $"$ & $\begin{array}{l}\text { leucomelas, W ied. } \\
\text { multifaria, Walk. }\end{array}$ \\
\hline & ", & nobilis, Wied. \\
\hline & $"$ & rostrata, $\mathrm{L}$ \\
\hline * & ", & $\begin{array}{l}\text { sexfasciata, Walk. } \\
\text { spiloptera, Wied. }\end{array}$ \\
\hline
\end{tabular}


Pangonia thoracica, Wied.

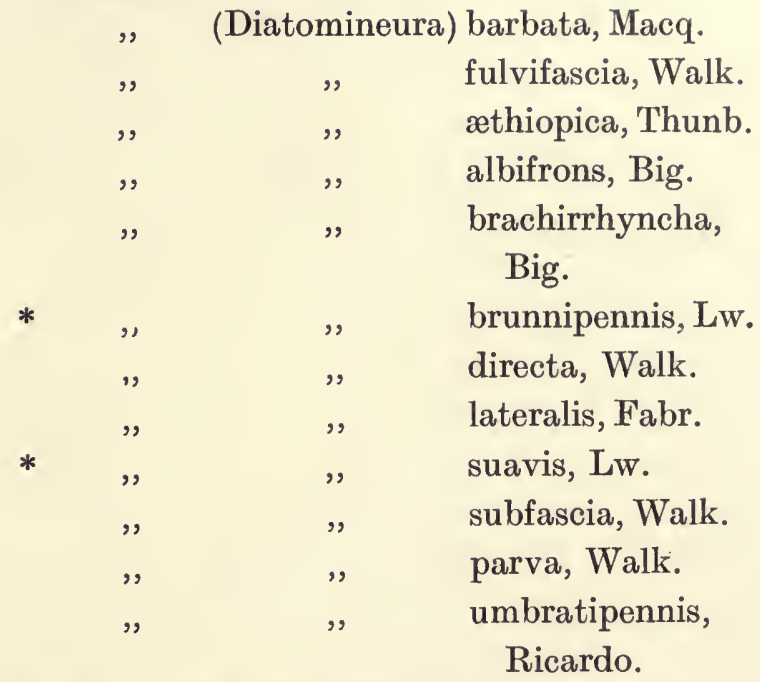

* Tabanus africanus, Gray.

* „ albilinea, Walk.

" atrimanus, Lw.

* $\quad$, biguttatus, Wied.

brunneus, Thunb.

capensis, Wied.

diurnus, Walk.

fallax, Macq.

* „, fraternus, Macq.

fulvianus, Lw.

(?) fuscinervis, Macq.

gratus, Lw.

hebes, Walk.

infans, Walk.

* $\quad$ insignis, Lw.

lævifrons, Lw.

macrodonta, Macq.

* „ maculatissimus, Macq.

nanus, Wied.

" obliquemaculatus, Macq.

* „ par, Walk. 
Tabanus sagittarius, Macq.

$$
\begin{aligned}
& \text { " sericiventris, } \mathrm{Lw} \text {. } \\
& \text { " subelongatus, Macq. } \\
& \text {, sulcipalpus, Lw. } \\
& \text { * " } \quad \text { tæniatus, Macq. } \\
& \text { " tenuicornis, Macq. } \\
& \text { * " ustus, Walk. } \\
& \text { * „ } \quad \text { variabilis, Lw. } \\
& \text { * } \quad \text { " variatus, Walk. } \\
& \text { " vexans, Lw. } \\
& \text {,, zoulouensis, Big. }
\end{aligned}
$$

Hæmatopota bistrigata, Lw.

$$
\text { * } \quad \text { circumscripta, Lw. }
$$

* $\quad$ decora, Walk.

, duplicata, Lw.

, imbrium, Wied.

, obscura, Lw.

, ocellata, Wied.

, recurrens, $\mathrm{Lw}$.

, ruficornis, Macq.

„ scutellaris, Lw.

, vittata, $\mathrm{Lw}$.

Muscide $\quad . \quad \ldots \quad *$ Stomoxys calcitrans, L.

Lyperosia potans, Bezzi.

Hippóoscide .. Hippobosca capensis, v. Olf.

$$
\begin{array}{lll} 
& \quad & \text { equina, Linn. } \\
* & \quad, & \text { rufipes, v. Olf. } \\
& \quad & \text { struthionis, Janson. }
\end{array}
$$

Echestypus sepiaceus, Speis.

Pseudolfersia spinifera, Leach.

Olfersia minor, Big.

Lynchia capensis, Big.

Ornithomyia fur, Schin.

" (?) laticornis, Macq.

" platycera, Macq. 
II.

FRENCH COLONIES AND PROTECTORATES.

Mauritania.

TAbanid $\ldots \quad \ldots *$ Tabanus biguttatus, Wied.

* ", ditæniatus, Macq.

* " latipes, Macq.

* , tæniola, Pal. de Beauv.

Senegal.

Tabanide .. . . * Chrysops longicornis, Macq.

Pangonia senegalensis, Macq.

Tabanus albicans, Macq.

, aquilus, Surcouf.

* ", biguttatus, Wied.

, chevalieri, Surcouf.

* , ditæniatus, Macq.

* $\quad$, fasciatus, Fabr.

* " fraternus, Macq.

", guineensis, Wied.

* , latipes, Macq.

* $\quad$, laverani, Surcouf.

* , par, Walk.

* $\quad$ " pluto, Walk.

* , $\quad$ secedens, Walk.

* ., socialis, Walk.

, sticticolis, Surcouf.

* $\quad$, subangustus, Ricardo.

" sufis, Jaenn.

* $\quad$ " tæniola, Pal. de Beauv.

, unimaculatus, Macq.

MUSCID

Lyperosia longipalpis, Roubaud (? = L. minuta, Bezzi). thirouxi, Roubaud. 
198

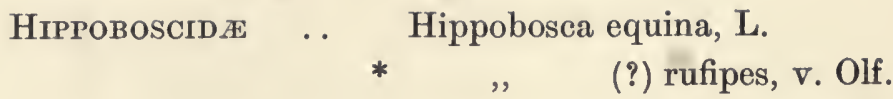

French Sudan (Senegambia-Niger).

Psychodid z $\quad$. * Phlebotomus duboseqi, Neveu-Lemaire.

TABANIDE . . . . * Tabanus africanus, Gray.

* , $\quad$ biguttatus, Wied.

" , ,. form croceus,

Surcouf.

"unimaculatus, Macq.

" canescens, Surcouf.

* $\quad, \quad$ canus, Karsch.

* , ditæniatus, Macq.

* " gratus, Lw.

* ", latipes, Macq.

* , $\quad$ par, Walk.

, sudanicus, Cazalbou.

* ", tæniola, Pal. de Beauv.

* " variatus, Walk.

* Hæmatopota decora, Walk.

, pulchrithorax, Austen.

Hippocentrum strigipennis, Karsch.

" trimaculatum, Newstead.

Muscide $\quad . \quad$.. Stomoxys bouffardi, $\dagger$ Picard.

Hippoboscid ж) .. Hippobosca camelina, Leach.

French Guinea.

Simulitd .. . . * Simulium damnosum, Theob.

TABanid $\ldots$.. . * Tabanus argenteus, Surcouf.

* ", biguttatus, Wied.

", boueti, Surcouf.

$\uparrow$ Quite unrecognisable from the description, but probably a synonym of either $S$. calcitrans, Linn., or S. nigra, Macq. 
Tabanus chevalieri, Surcouf.

* " fasciatus, Fabr.

" guineensis, Wied.

* $\quad$ " kingsleyi, Ricardo.

* , laverani, Surcouf.

" martini, Surcouf.

* " pluto, Walk.

" ricardæ, Surcouf.

* $\quad$, ruficrus, Pal. de Beauv.

* , secedens, Walk.

* $\quad$, socialis, Walk.

„ sticticolis, Surcouf.

* $\quad$, tæniola, Pal. de Beauv.

* $\quad$, unilineatus, Lw.

" variabilis, Isw.

Hippocentrum strigipennis, Karsch.

French Ivory Coast (Grand Bassam and Assinie).

TABanid $\ldots$. . . Pangonia semilivida, Big.

Tabanus boueti, Surcouf.

i combustus, Big.

" conformis, Walk.

* $\quad$, socialis, Walk.

* " $\quad$ thoracinus, Pal. de Beauv.

Hæmatopota cordigera, Big.

French Congo and Gaboon.

Simulimd . . . * * Simulium damnosum, Theob.

" reptans, L.

TABanid $2 . . \quad \ldots \quad *$ Chrysops dimidiata, v. d. Wulp.

* , distinctipennis, Austen.

Subpangonia gravoti, Surcouf.

* Tabanus argenteus, Surcouf.

"besti, Surcouf. 
* Tabanus biguttatus, Wied.

* , $\quad$ canus, Karsch.

" combustus, Big.

" conformis, Walk.

* " congoiensis, Ricardo.

* " fasciatus, Fabr.

* " gratus, Lw.

, ianthinus, Surcouf.

" maculatissimus irroratus, Surcouf.

* " obscurefumatus, Surcouf.

* $\quad$ " obscurissimus, $\dagger$ Ricardo.

* " par. Walk.

* $\quad$ " thoracinus, Pal. de Beauv.

* " pluto, Walk.

* " $\quad$ ruficrus, Pal. de Beauv.

* $\quad$ " secedens, Walk.

* " socialis, Walk.

* " $\quad$ tæniola, Pal. de Beauv.

" testaceiventris, Macq.

* Hæmatopota decora, Walk.

" inappendiculata, Big.

Hippocentrum strigipennis, Karsch.

" trimaculatum, Newstead.

Muscide $\quad . \quad$.. Stomoxys bouvieri, Roubaud.

intermedia, Roubaud.

Lyperosia pallidipes, Roubaud.

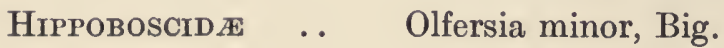

French Somaliland.

Tabanide.. $\quad$.. Pangonia subfasciata, Walk.

* $\quad$ zonata, Walk.

$\uparrow$ Perhaps $=$ T. ianthinus, Surcouf. 
III.

GERMAN COLONIES.

Togoland.

Tabanid $\ldots \quad$.. Thriambeutes singularis, Grünb.

* Tabanus fasciatus, Fabr.

* „ tæniola, Pal. de Beauv.

Muscide $\ldots \quad \ldots \quad *$ Stomoxys calcitrans, L.

* $\quad$, nigra, Macq. (glauca, Grünb.).

Lyperosia minuta, Bezzi.

НтртовозсіDж $\quad . \quad *$ Hippobosca maculata, Leach.

Cameroon.

Tabanide.. $\quad \ldots \quad *$ Chrysops dimidiata, v. d. Wulp.

* Tabanus æneus, Surcouf.

* " congoiensis, Ricardo.

* ruficrus, Pal. de Beauv.

* „, secedens, Walk.

Thaumastocera akwa, Grünb.

Hæmatopota cordigera, Big.

Muscid $\quad$. $\quad$.. $\quad$ Stomoxys brunnipes, Grünb.

* " inornata, Grünb.

* $\quad$, nigra, Macq. (glauca, Grünb.).

\section{German South-West Africa. $\dagger$}

Hippoвoscid $е$. * Hippobosca rufipes, v. Olf.

German East Africa.

TABANID $\ldots \quad \ldots \quad *$ Chrysops bicolor, Cordier (nigriflava, Austen).

(?) longicornis, Macq.

$\uparrow$ The British Museum (Natural History) as yet possesses no material from German South-West Africa. The species recorded above is the only one mentioned by Grünberg ("Die Blutsaugenden Dipteren." Jena: Gustav Fischer, 1907) as occurring in this colony. 
Silvius innotatus, Karsch.

, oestroides, Karsch.

* Pangonia elongata, Ricardo.

" mesembrinoides, Surcouf.

„ (Diatomineura) æthiopica, Thunb.
, distincta, Ricardo.

* Tabanus africanus, Gray.

* , biguttatus, Wied.

* , fraternus, Macq.

, imbecillus, Karsch.

, impurus, Karsch.

* quadriguttatus, Ricardo.

* $\quad$, tæniola, Pal. de Beauv.

* , variatus, Walk.

Holcoceria nobilis, Grünb.

Hæmatopota albihirta, Karsch.

, alluaudi, Surcouf.

, hieroglyphica, Gerst.

„ hirta, Ricardo.

, maculiplena, Karsch.

,, pulchrithorax, Austen.

Parhæmatopota cognata, Grünb.

Muscid $\ldots$. . . Stomoxys bilineata, Grünb.

, brunnipes, Grünb.

* , calcitrans, L. (korogwensis, Grünb.).

Lyperosia schillingsi, Grünb.

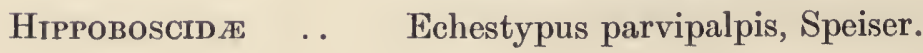

IV.

ITALIAN COLONIES.

ERITREA.

Tabanid . . . . Pangonia magrettii, Bezzi.

* Tabanus maculatissimus, Macq. 


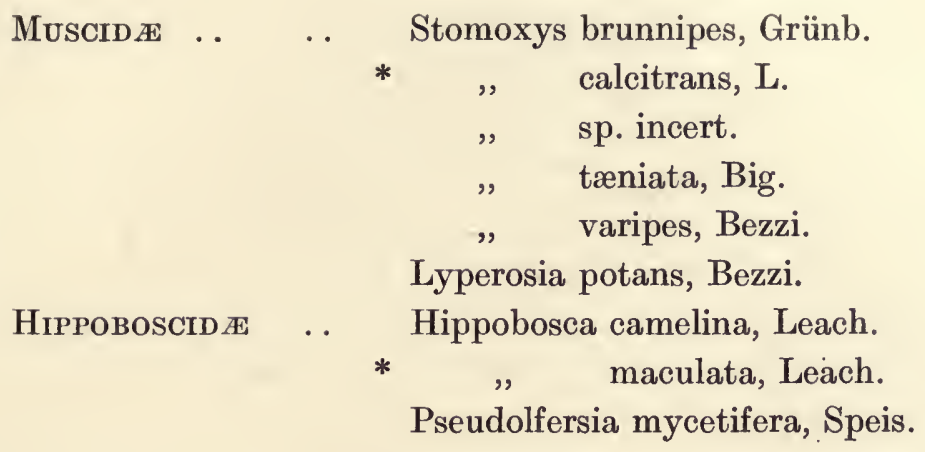

(Italian Somaliland-see Somaliland.)

V.

\section{PORTUGUESE COLONIES AND DEPENDENCIES.}

Prince's Island.

Tabanid $\ldots$.. . . * Tabanus tæniola, Pal. de Beauv.

\section{Cabinda.}

TABanid $\ldots$.. $\quad *$ Chrysops dimidiata, v. d. Wulp.

* Tabanus canus, Karsch.

* " congoiensis, Ricardo.

* " obscurefumatus, Surcouf.

" subvittatus, Ricardo.

* " thoracinus, Pal. de Beauv.

Hæmatopota laverani, Surcouf.

Hippocentrum trimaculatum, Newstead.

Angola.

Simulimde $\quad \ldots *$ * Simulium wellmanni, Rouband.

Tabanide. . . . Chrysops wellmanii, Austen.

* Tabanus africanus, Gray.

* " biguttatus, Wied. 
* Tabanus canus, Karsch.

$$
\begin{aligned}
& \text {, conformis, Walk. } \\
& \text { * } \quad \text { " distinctus, Ricardo. } \\
& \text { * , ditæniatus, Macq. } \\
& \text { * } \quad \text { exclamationis, Giard. } \\
& \text { *, pluto, Walk. }
\end{aligned}
$$

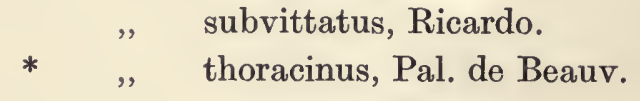

$$
\begin{aligned}
& \text {, tritæniatus, Ricardo. } \\
& \text { * } \quad \text {, variatus, Walk. } \\
& \text { * , wellmanii, Austen. } \\
& \text {, brunnipennis, Ricardo. } \\
& \text {, desidiosa, Austen. } \\
& \text {, fulva, Austen. } \\
& \text {, hirsutitarsus, Austen. } \\
& \text {, hostilis, Austen. } \\
& \text {, inflaticornis, Austen. } \\
& \text {," insidiatrix, Austen. } \\
& \text {," molesta, Austen. } \\
& \text {, pallidimarginata, Austen. } \\
& \text { " semiclara, Austen. } \\
& \text {, } \quad \text { virgatipennis, Austen. } \\
& \operatorname{Muscid} \approx \ldots \quad \ldots \quad * \text { Stomoxys calcitrans, L. }
\end{aligned}
$$$$
\text { Hippoвоscid 瓜 . * * Hippobosca rufipes, v. Olf. }
$$

Portuguese East Africa.

Tabanid E . . . C Chrysops fusca, Ricardo.

Pangonia rondanii, Bertol.

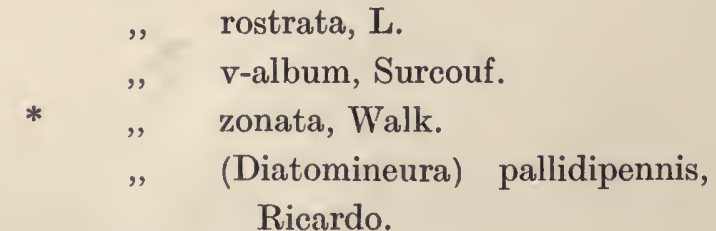

$$
\begin{aligned}
& \text { * Tabanus africanus, Gray. }
\end{aligned}
$$


* Tabanus biguttatus, Wied.

* " ditæniatus, Macq.

* " fraternus, Macq.

" inhambanensis, Bertol.

* $\quad$, liventipes, Surcouf.

* " par, Walk.

* " $\quad$ thoracinus, Pal. de Beauv.

* " subelongatus, Macq.

* $\quad$, tæniola, Pal. de Beauv.

" unilineatus, Lw.

, unitæniatus, Ricardo.

* , $\quad$ ustus, Walk.

* " $\quad$ variatus, Walk.

* Hæmatopota decora, Walk.

, longa, Ricardo.

" mactans, Austen.

,, niveipes, Surcouf.

" pulchrithorax, Austen.

Muscid $\ldots$.. $\quad$ * Stomoxys calcitrans, L.

Нippoвоsсid ж .. * Hippobosca maculata, Leach.

VI.

ABYSSINIA.

Tabanid a .. . . * Chrysops distinctipennis, Austen. Pangonia magrettii, Bezzi.

* $\quad$, rüppellii, Jaenn.

" (Diatomineura) distincta, Ricardo.

Tabanus agrestis, Wied.

, agricola, Wied.

* $\quad$, biguttatus, Wied.

" obscuripes, Ricardo.

, mesnili, Surcouf. 
Tabanus psusennis, Jaenn. (?=T. leucostomus, Lw.)

* " variatus, Walk.

„ velutinus, Surcouf.

Hæmatopota abyssinica, Surcouf.

lathami, Surcouf.

mactans, Austen.

meteorica, Corti.

mordax, Surcouf.

picta, Surcouf. pulchrithorax, Austen. sidamensis, Surcouf. vicina, Surcouf.

Muscide $\quad . \quad \ldots *$ Stomoxys calcitrans, L.

" tæniata, Big.

" varipes, Bezzi.

Lyperosia minuta, Bezzi.

Нippoвоscid ж .. Hippobosca camelina, Leach.

" maculata, Leach.

VII.

ANGLO-EGYPTIAN SUDAN.

Srmulind .. . . * Simulium damnosum, Theob.

* " griseicollis, Becker.

Psychodid ж2 .. Phlebotomus (?) papatasii, Scop.

Tabanid $\ldots$.. . * Chrysops brucei, Austen.

* Pangonia rüppellii, Jaenn.

, magrettii, Bczzi.

* Tabanus africanus, Gray.

* " biguttatus, Wied.

* " ditæniatus, Macq.

" fasciatus, Fabr. subsp. niloticus, Austen. 
* Tabanus gratus, Lw.

* " latipes, Macq.

" leucostomus, Lw. (? syn. T. psusennis, Jaenn.).

" ? sp. nov.

* $\quad$, par, Walk.

", sufis, Jaenn.

* " $\quad$ tæniola, Pal. de Beauv.

"unitæniatus, Ricardo.

* Hæmatopota decora, Walk.

* $\quad$ denshamii, Austen.

" pulchrithorax, Austen.

" taciturna, Austen.

$" \quad$ tenuis, Austen.

* Hippocentrum versicolor, Austen.

MUSCID $\quad \ldots \quad \ldots \quad *$ Stomoxys calcitrans, L.

* „, nigra, Macq.

Lyperosia minuta, Bezzi.

Нıртовоscid ж .. Hippobosca camelina, Leach.

$$
\text { * } \quad " \quad \text { capensis, v. Olf. }
$$

Lipoptena chalcomelæna, Speiser.

VIII.

CONGO FREE STATE.

Chironomide $\quad . \quad *$ Culicoides grahamii, Austen.

Simulimd $\quad \ldots$ * Simulium damnosum, Theob.

, sp.

TABANID $\ldots$.. . . * Chrysops silacea, Austen.

* Tabanus africanus, Gray.

* " $\quad$ biguttatus, Wied.

" " ",$\quad$ form croceus,

Surcouf. 
* Tabanus billingtoni, Newstead.

* " $\quad$ brucei, Ricardo.

* , , canus, Karsch.

, claripes, Ricardo.

, conformis, Walk.

* , , congoiensis, Ricardo.

, coniformis, Ricardo.

, combustus, Big.

* , , denshamii, Austen.

," disjunctus, Ricardo.

* , ditæniatus, Macq.

, diversus, Ricardo.

* , fasciatus, Fabr.

, guineensis, Wied.

, ianthinus, Surcouf.

* , latipes, Macq.

* , laverani, Surcouf.

, lemairei, Surcouf.

* " maculatissimus, Macq.

, , , form irroratus, Surcouf.

* , obscurissimus, Ricardo. $\dagger$

, obscurehirtus, Ricardo.

, obscurestriatus, Ricardo.

, obscurior, Ricardo.

* . par, Walk.

* , , pluto, Walk.

* $\quad$, quadrisignatus, Ricardo.

* $\quad$, quadriguttatus, Ricardo.

* " $\quad$ ruficrus, Pal. de Beauv.

* $\quad$, secedens, Walk. severini, Surcouf.

, testacciventris, Macq.

* " thoracinus, Pal. de Beauv.

* , ustus, Walk.

$\dagger$ Perhaps $=$ T. ianthinus, Surcouf. 
* Tabanus variabilis, Lw.

* „ wellmanii, Austen.

Hæmatopota brunnipennis, Ricardo.

, cordigera, Big.

" cruenta, Austen.

" divisapex, Austen.

" duttoni, Newstead.

" laverani, Surcouf.

" masseyi, Austen.

" ochracea, Bezzi.

", vexans, Austen.

Hippocentrum trimaculatum, Newstead.

MUscide $\quad . \quad$.. $\quad$ Philæmatomyia insignis, Austen.

* Stomoxys calcitrans, L.

* " nigra, Macq.

* $\quad$ omega, Newstead.

НippoвоSCID ж $\ldots *$ Hippobosca rufipes, v. Olf.

Lipoptena paradoxa, Newstead.

IX.

EGYP'T.

Chironomid же .. Johannseniella (Ceratolophus, Kieffer) imparunguis, Becker.

Psychodid $\quad$. $\quad$ Phlebotomus (?) papatasii, Scop.

STMULID \& $\quad$. * Simulium griseicollis, Becker.

TABAnID 2 . . . . Tabanus agrestis, Wied.

" agricola, Wied.

" albifacies, Lw.

" alexandrinus, Wied.

* $\quad$ " ditæniatus, Macq. 
Tabanus eggeri, Schin.

* „ $\quad$ gratus, Lw.

„ siccus, Walk.

* „, tæniola, Pal. de Beauv.

"unicinctus, Lw.

„ unifasciatus, Lw.

Muscide $\ldots \quad \ldots \quad *$ Stomoxys calcitrans, L.

Нrтрово

" capensis, v. Olf.

" equina, $\mathrm{L}$.

* " maculata, Leach.

Lipoptena cervi, L.

X.

LIBERIA.

Tabanid $\ldots$.. . $*$ Tabanus pluto, Walk.

* $\quad$ secedens, Walk.

* $\quad$ socialis, Walk.

XI.

SOMALILAND.

TABANID $2 \ldots \quad \ldots *$ Chrysops stigmaticalis, Lw.

* Pangonia beckeri, Bezzi.

" bricchettii, Bezzi.

* " magrettii, Bezzi.

* zonata, Walk.

* Tabanus biguttatus, Wied.

* " ditæniatus, Macq.

* " gratus, Lw.

* , maculatissimus, Macq.

" morsitans, Ricardo. 
Tabanus obliquemaculatus, Macq.

„ subelongatus, Macq.

* " tæniola, Pal. de Beauv.

Hæmatopota albihirta, Karsch.

* $\quad, \quad$ coronata, Austen.

* $\quad$ mactans, Austen.

MUsoid

Lyperosia minuta, Bezzi.

Hippoвоscid жа .. Hippobosca camelina, Leach.

" capensis, v. Olf.

* " maculata, Leach.

Ornithomyia nigricans, Leach. 



\section{INDEX.}

A

Abyssinia, list of species, 205.

adjuncta (Pangonia), 60.

æneus (Tabanus), 110.

africanus (Tabanus), 81.

agrestis (Tabanus), 120.

agricola (Tabanus), 120.

Akhl-es-Skout, Arabic name of Phlebotomus (? papatasii) in Egypt, 18 (note).

akwa (Thaumastocera), 66.

albilinea (Tabanus), 112.

Anglo-Egyptian Sudan, list of species, 206.

Angora, list of species, 203.

angulata (Pangonia), 60.

Anthrax and Pangonia (in New Caledonia), 58.

argenteus (Tabanus), 114.

Ashantr, list of species, 183.

Atylotus (subgenus of Tabanus), 120. nigromaculatus $(=T$. ditæniatus), 120.

\section{B}

Balaad (Baal ad, Baal at), Somali name for Tabanus morsitans, 63, 117 ; applied to $\mathrm{T}$. ditæniatus, and apparently indiscriminately to any small Tabanid, 119.

barbata (Pangonia), 55.

Basal cells (in wings of Tabanidæ), 121 (note).

Beccarimyia, 136 (note).

- glossina (believed not to be a blood-sucking species), 136 (note)

beckeri (Pangonia), 63.

bicolor (Chrysops), 48.

biguttatus (Tabanus), 69, 85 .

billingtoni (Tabanus), 96.

bouffardi (Stomoxys), 150 (note).

brucei (Culicoides), 6.

- (Hæmatopota), 128.

- (Tabanus), 81.

brumpti (Tabanus), 93.

brunnescens (Hæmatopota), (note), 127

brunnipennis (Pangonia (Diatomineura)), 65 .

bullatifrons (Hæmatopota), 127.
C

Cabinda, list of species, 203.

Cadicera, external characters, 52.

- chrysostigma, 53.

_ melanopyga, 53.

quinquemaculata, 54.

rubramarginata, 52.

calcitrans (Stomoxys), 142.

calida (Chrysops), 49.

camelina (Hippobosca), 168, 169.

Cameroon, list of species, 201.

canus (Tabanus), 110.

Cape Colony, list of species, 193.

capensis (Hippobosca), 168.

- (Tabanus), 117.

Ceratopogon castaneus, not a bloodsucking species, 2 (note).

Ceratopogoninæ, 1 ; number of bloodsucking African species at present known, 2.

cervi (Lipoptena), 164.

chalcomelæna (Lipoptena), 164.

Chimbu, Angoni name for Pangonia (Nyasaland), 58.

Chironomidæ (Midges), 1.

Chrysops, number of Ethiopian species ; external characters, 42 ; lifehistory, 43.

- and disease, 44.

- bicolor (syn. Ch. nigriflava), 48.

brucei, 50 .

calida, 49.

dimidiata; bloodthirstiness of, 47 ; native names of, in French Congo, 48.

dimidiata and $\mathrm{Ch}$. silacea in $\mathbf{S}$. Nigeria (observations by Mr. G. G. Dudgeon), 43.

distinctipennis, 46.

funebris, 44.

longicornis, 44.

nigriflava (synonym of $\mathrm{Ch}$. bicolor), 48.

silacea, 48 .

—_ stigmaticalis, 45.

chrysostigma (Cadicera), 53.

Chrysozona (synonym of Hæmatopota), 120 (note).

(Hæmatopota) ochracea, 125.

claritibialis (Tabanus), 120.

cognata (Parhæmatopota), 66.

compacta (Pangonia), 61 . 
compacta centralis (Pangonia), 62.

Congo Free State, list of species, 207. congoiensis (Tabanus), 99.

conjuncta (Pangonia), 64.

conspicuus (Tabanus), 107.

copemanii (Hæmatopota), 123, 126.

Corizoneura, 54 (note).

coronata (Hæmatopota), 130.

costata (Rhinomyza), 51.

Culicoides, characters of genus, 3 ; number of species at present known; distribution of genus, 4 ; preliminary stages; life-history of African species not yet observed, 5.

brucei, 6 .

grahamii, the African representative of the European C. varius, 7 ; distinctive characters, 8; in Ashanti and Congo Free State, 7 ; in South-West Uganda, 8 ; irritating wheals caused by bites of, 8 ; blood-thirstiness of, and wide distribution in Tropical Africa, 7. milnei, 6.

\section{D}

damnosum (Simulium), 26.

decora (Hæmatopota), 128.

denshamii (Hæmatopota), 126. (Tabanus), 108.

denticornis (Rhinomyza), 51.

Diatomineura, 54 (note).

dimidiata (Chrysops), 47.

Discal cell (in wings of Tabanidæ), 121 (note).

disjunctus (Tabanus), 109.

distincta (Pangonia (Corizoneura)), 57.

distinctipennis (Chrysops), 46.

distinctus (Tabanus), I11.

ditæniatus (Tabanus), 118.

diversus (Tabanus), 72, 112.

DoERR, Dr. R., observations by, on Phlebotomus in Herzegovina (latrines only possible breeding place in height of summer), 15.

Doog (Dug), Somali name for species of Pangonia, 57, 63.

Drake-Brockman, Dr. R. E., on Pangonia (Corizoneura) distincta in Gamoji, Galla Land, NorthEast Africa, 57.

duboseqi (Phlebotomus), 20.

DUdGeon, G. C., observations on Chrysops dimidiata and $\mathrm{Ch}$. silacea in Southern Nigeria, 43 ; on species of Tabanus in Northern and Southern Nigeria, $68,69$.

Dug, Somali name for certain species of Tabanidx, 57.

duttoni (Hæmatopota), 126.
$\mathbf{E}$

East Africa Protectorate, list of species, 186.

Echestypus, 164, 165.

edentula (Rhinomyza), 51.

EGYPT, list of species, 209.

El debab (el debeh), a camel-disease in

North Africa, disseminated by

Tabanus (Atylotus) tomentosus and T. (A.) nemoralis, 70, 105 (and note).

elongata (Pangonia), 59.

El Takasha, native name for Hæmatopota sp. (probably H. taciturna) on Blue Nile, 124.

Empodium (median appendage of last tarsal joint) in genus Culicoides, 3.

equina (Hippobosca), 168.

Eritrea, list of species, 202.

Eu-Simulium, characters of subgenus, 23.

Eyes, colour of in Tabanidx, 37.

\section{$\mathbf{F}$}

Fayûm, Egypt, alleged existence of camel-killing fly in (possibly Tabanus tæniola), 105.

fasciatus (Tabanus), 69, 78 .

Filaria labiato-papillosa (? F. stomoxeos) and Stomoxys calcitrans, 148 (and notes).

Fourou, native name of Simulium damnosum at Brazzaville, French Congo, 28.

fraternus (Tabanus), 101.

French Congo and Gaboon, list of species, 199.

French Guinea, list of species, 198.

French Ivory Coast (Grand BASSAM AND ASSINIE), list of species, 199.

French Somaliland, list of species, 200.

French Sudan (Senegambia-Niger), list of species, 198.

fulva (Hæmatopota), 125.

fulvifascia (Pangonia), 55.

funebris (Chrysops), 44.

fuscipes (Tabanus), 120.

G

Gambia, list of species, 181.

Genera of Tabanidx, the four principal (Tabanus, Hrmatopota, Pangonia and Chrysops), 36.

German East Africa, list of species, 201. 
German South-West Africa, list of species, 201.

glossina (Baccarimyia), 136 (note).

Glossinella (= Lyperosia), 136 (note). schillingsi, 136 (note).

Gold Coast, list of species, 183.

Graham, Dr. W. M., on best method of catching Midges, 2.

grahamii (Culicoides), 7.

gratus (Tabanus), 114.

griseicollis (Simulium), 31.

gulosa (Pangonia), 62.

\section{H}

Hrmatobia, not yet definitely known to occur in Africa, 140.

Hæmatopota, 120 ; wing-markings, 121 ; characters useful for distinction of species, 122; bloodthirstiness, 123; life-history, 123. number of Ethiopian and nonEthiopian species, 121.

and disease, 124.

brucei, 128.

brunnescens, 122 (note), 127.

bullatifrons, 127.

copemanii, 123, 126.

coronata, $122,130$.

decora, 125, 128.

denshamii, $122,126$.

dorsalis (= H. decora), 128.

duttoni, 126.

fulva, 125 .

lacessens, 132 ; differences from

H. tenuicrus, 133 .

laverani, 126.

mactans, 129.

noxialis, 125.

pallidipennis, 127.

pertinens, 123, 126.

pluvialis, life-history, 123.

pulchrithorax, 122 (note).

similis, 126.

taciturna, 124.

tenuicrus, 133.

torquens, 131; differences from

H. cordigera, 131, 132.

ugandæ, 122, 132.

unicolor, 126

vittata, 122 (note).

Hinea, 41, 42.

Hippobosca, 167 ; external characters, 167, 168 ; number of Ethiopian species, 168 ; life-history, 169.

and disease, 171.

capensis, 168.

camelina, 168, 169.

dromedarina (= H. camelina), 169.

equina, 168

francilloni (= H. capensis), 168.
Hippobosca maculata, 169, 171, 173 ; occurrence outside Africa; observations by Dr. W. M. Graham in Ashanti ; may occasionally bite man, 174; life-history, 175 ; as a disease-carrier, 176 .

rufipes, 171, 176; puparium, 178; as a disease-carrier, 178.

- struthionis (parasitic on the ostrich, Struthio australis), 171 ; effects on ostriches and their feathers in Cape Colony, 172.

Hippoboscidæe (permanent parasites of mammals and birds), appearance, 163; tarsal claws; bites apparently not painful; occasionally bite human beings; lifehistory, 165.

- and disease, 166

Hippocentrum; differences from Hæmatopota, 133.

(Hrmatopota) strigipennis, 134. trimaculatum (Hæmatopota trimaculata), 134, 135 ; eye-markings, 134 (note).

versicolor, 134; differences from H. trimaculatum, 135.

Hippo-flies (Tabanidæ), 36.

Hla Bowu, native name for Tabanus africanus in Lorenzo Marques, (observations by Mr. F. D. MeMillan), 83.

Holcoceria, 66.

nobilis, 66 .

Holmes, CApt. J. D. E., I.M.S., observations on Phlebotomus and surra in India, 18 (note).

Horse-flies (Tabanidæe), 36.

\section{I}

Imvu Bowu, native name for Tabanus biguttatus in Lorenzo Marques (observations by Mr. F. D. McMillan), 88.

insignis (Tabanus), 72.

- (Philømatomyia), 137, 138, 140:

Itouna (native name of Chrysops dimidiata in French Congo), 48.

$$
\mathrm{J}
$$

"Jinja" cattle-disease and Stomoxys in Uganda; transmission experiments by Minchin, Gray, and Tulloch, 150 ; by Greig and Gray, 151.

"Jinja fly," local name of Simulium damnosum near Jinja, on Victoria Nile, Uganda, 27.

Johannseniella (syn. Ceratolophus), distinctive characters of, from Culicoides, 2. 
K

Kilteb (or Kunteb), local name of Simulium damnosum near Abu Hamed, River Nile, AngloEgyptian Sudan, 29.

KING, H. H., on life-history of Simulium damnosum, 29 ; S. griseicollis, 32 , and Tabanus biguttatus, 89 .

kingsleyi ('Tabanus), 98.

\section{L}

lacessens (Hæmatopota), 132.

lateralis (Pangonia (Corizoneura)), 61.

latipes (Simulium), 25.

- (Tabanus), 84.

laverani (Hæmatopota), 126. (Tabanus), I15.

lemairei (Tabanus), 99.

LIBERIA, list of species, 210.

Lipoptena, 163, 164, 165. cervi, 164 chalcomelæna, 164.

liventipes (Tabanus), 107

longicornis (Chrysops), 44.

Lynchia, 164.

Lyperosia; how distinguished from Stomoxys; coloration and other external characters; number of known African species, 160 ; lifehistory, 161.

and disease, 161.

longipalpis (possibly $=$ L. $\mathrm{mi}$ nuta), 160 (note). punctigera, 162. thirouxi, 140.

mactans (Hæmatopota), 129.

maculata (Hippobosca), 173.

maculatissimus (Tabanus), 91.

irroratus (Tabanus), 91.

maculosa (Stygeromyia), 136.

Mal de la Zousfana (trypanosomiasis of horses in Algeria), 124.

Mangrove-flies (Tabanidæ), 36.

marmoratus (Tabanus), 95.

Mauritania, list of species, 197.

Mbori,a trypanosomiasis of dromedaries at Timbuctu, said to be propagated by Tabanus ditreniatus and $T$. biguttatus, 72 .

Mbwa, native name of Simulium damnosum in Uganda, 28.

Mbwari, Ankondi name for Pangonia (Nyasaland), 58.

melanopyga (Cadicera), 53.
Melophagus ovinus ("Sheep Tick"), 164 ; probably occurs on sheep in South Africa, 165.

Midges (Chironomidæ); distinctive characters of, from Mosquitoes (Culicidæ); external structural characters, I; proper method of collecting and preserving, 2 ; smallest of all blood-sucking flies, 1; blood-sucking habit exceptional in; confined to females of relatively few species, belonging to subfamily Ceratopogoninæ, 1.

(species of Culicoides), known as "Sand-flies" by Europeans in Ashanti and on Gold Coast; nuisance caused by, in Ashanti, 4. in Busoga, Uganda (Dr. C. Christy's observations), 4 ; in Nyasaland Protectorate and NorthEastern Rhodesia (Mr. R. L. Harger's observations), 5.

milnei (Culicoides), 6.

morsitans (Tabanus), 117.

Mouche bœuf, name applied to Stomoxys nigra in Mauritius, 157 (note).

Muscidæ; blood-sucking habit highly exceptional in this family, confined to very few genera and species, but common to both sexes; blood - sucking genera known to occur in Ethiopian Region, 136.

African blood-sucking ; dimensions, coloration, proboscis, 140. (blood-sucking) and disease, 141 ; life-history, 141.

Mycteromyia, 41 .

\section{$\mathrm{N}$}

Natal, list of species, 192.

N'gaya illi, native name for Tabanus tæniola near Lake Chad, 103.

Nigeria, Northern, list of species, 184.

Southern, list of species, 185.

nigra (Stomoxys), 153.

nigrostriatus (Tabanus), 107.

Nimbu, Ahenga name for Pangonia (Nyasaland), 58.

Nimitti (Nimetta or Nemetti), local name of Simulium griseicollis in Dongola Province, Anglo-Egyptian Sudan, 31 (and note).

N'kuti, native name applied to Simulium on Lulanga River, Upper Congo, 23.

nobilis (Holcoceria), 66. 
Nok̀, Dr. Grovanni, investigations in Italy on Stomoxys calcitrans and Filaria labiato-papillosa, of the ox, 148 (and notes).

noxialis (Hæmatopota), 125.

nyasæ (Tabanus), 109.

Nyasatand Protectorate, list of species, 189.

\section{O}

obscurefumatus (Tabanus), 94.

obscurissimus (Tabanus), 69, 73.

ochracea (Chrysozona (Hæmatopota)), 125.

Ohomono, native name of Simulium wellmanni, in Bihé, Angola, 30.

OLD, DR. J. E. S., observations on Pangonia in Nyasaland, 58.

oldii (Pangonia), 57, 58.

Olfersia, 164.

Orange River Colony, list of species, 192.

Oriental sore in Egypt, assertion by Dr. A. Pressat as to apparent agency of Phlebotomus in its dissemination, 18.

Ornithoica, 164.

Ornithomyia, 164.

ovinus (Melophagus), 164.

\section{$\mathbf{P}$}

pallidipennis (Hæmatopota), 127.

Pangonia, table of divisions of genus, 54 (note) ; bloodthirstiness of females, 56 ; number of described Ethiopian species, 54; distribution of African species; proboscis, 55.

and disease, Pangonia and anthrax (in New Caledonia), 58.

life-history not yet observed, 58 . adjuncta, 60 .

angulata, 60 ; differences from P. conjuncta, 61 .

barbata, 55 .

beckeri, 63 .

(Diatomineura) brunnipennis, 65. compacta, 61 . centralis (Nyasaland), observations by Dr. J. E. S. Old, 62. conjuncta, 64 .

(Corizoneura) distincta, a plague of domestic animals in Gamoji, Galla Land, North-East Africa, in October (observations by Dr. R. E. Drake-Brockman), 57.

elongata, 59.

fulvifascia, 55 .

gulosa, 62 .
Pangonia (Corizoneura) lateralis, 61.

- magrettii, 64; $P$. magrettii and disease in domestic animals, 58.

oldii (Nyasaland), following nswala antelope ( Epyceros melampus); attacking man (observations by Dr. J. E. S. Old), 58.

- rostrata, 61; in Cape Colony (Westermann's observations), 56, 62.

rüppellii, 64.

- _ - sucking blood on the wing (observations by Dr. H. A. Foy in N. Nigeria), 56. and disease in domestic animals, 58.

sexfasciata, 59.

(Diatomineura) suavis, 65. zonata, 59.

Pangoniinæ (subfamily of Tabanidæ), names of African genera of, 41.

" Pappataci" (Phlebotomus papatasii), $13,15,18$.

Pappataci fever, disseminated by Phlebotomus papatasii, 18,19 ; resemblance of, to dengue and Mediterranean " Simple Continued Fever ", 19 ; percentage of AustroHungarian troops attacked by the disease each summer in South Herzegovina and Dalmatia, 19.

par (Tabanus), 76.

Parhæmatopota, 66, 122 (note). cognata, 66, 122 (note).

Pearson, Dr. Arthur, on Tabanidæ, other biting flies and sleeping sickness, 40 (note).

pertinens (Hæmatopota), 123, 126.

Philæmatomyia, 137 ; structure of proboscis, 138 ; other characters of the genus, 139 ; a connecting link between Stomoxys group and nonbiting Muscidæ, 139. insignis, 137, 138, 140.

Phlebotomus ("Sand-flies"), appearance and distinctive characters, 10 ; common in latrines in Herzegovina, Egypt, Ashanti, and Uganda, 15; distribution, 10 ; num ber of African species at present uncertain, 19; habits, resting attitude, silent flight; essentially nocturnal, attracted by artificial light, 11 ; sometimes bite by day ; usually bite indoors, rarely in the open; severity of and irritation caused by bite; penetrate ordinary mosquito-curtains, and crawl under bed-clothes; Howlett's observations in India ; cattle, dogs, frogs, and caterpillars attacked as well as human beings, 12. 
Phlebotomus life-history, 13 ; metamorphoses first discovered by Grassi; latter's results confirmed by Howlett,in India, 14; chief breedingplaces probably permanent latrines and privies, 15 ; breeding-places of African species not yet known, 14; meal of blood necessary to female after fertilisation, for development of eggs; eggs of $\mathrm{Ph}$. papatasii and Indian species, 15; food of larva (Indian species), 15; (Ph. papatasui), 16.

larva, 16; duration of life-cycle of Indian species, 17.

- in Anglo-Egyptian Sudan (Kassala and Khartoum), 20.

as a disease-carrier, 17.

a possible disseminator of Surra in India, 18 (and note).

duboseqi, 20 ; habitat as at present known, 20 ; differences from Ph. papatasii, 21.

papatasii in S. Europe, 11 ; painful bite; reaction shown by individuals bitten; preference for particular regions of the body exhibited by the insects when biting (in Herzegovina), 13 ; lifehistory, 14-17.

apparently a true host of the virus of Pappataci fever, 19.

- (? papatasii), common throughout Egypt except at Port Said (Dr. E. H. Ross), 20.

pluto (Tabanus), 91.

Portuguese East Africa, list of species, 204.

Pressat, Dr. André, on Phlebotomus and Oriental sore in Egypt, 18.

Prinoe's Island, list of species, 203.

Proboscis, exceptional length of, in certain species of Pangonia, 55, 56. in Tabanidæ, 37.

_ - in Philæmatomyia, 138. and palpi in Hippoboscidæ, 164.

Pronopes, 41, 42.

Pro-Simulium, characters of subgenus, 23.

Pseudolfersia, 164.

Psychodidx ("Motll-flies "), characters of; blood-sucking species belong to subfamily Phlebotominx, 9.

pulchrithorax (Hæmatopota), 122 (note).

pusilla (Rhinomyza), 51.

\section{Q}

quadriguttatus (Tabanus), 94 . quadrisignatus (Tabanus), 111. quinquemaculata (Cadicera), 54.
$\mathbf{R}$

Rhinomyza, 50.

costata, 51.

denticornis, 51.

edentula, 51.

pusilla, 51

Rhodesia, North-Eastern, list of species, 190.

North-Western, list of species, 190.

Southern, list of species, 191.

rostrata (Pangonia), 61, 62.

rothschildi (Tabanus), 116.

rubramarginata (Cadicera), 52.

ruficrus (Tabanus), 92.

rufipes (Hippobosca), 176.

rüppellii (Pangonia), 64.

ruwenzorii (Tabanus), 117, 118.

\section{S}

"Sand-flies" (Phlebotomus), appearance, distinctive characters, distribution, 19

a name sometimes applied to species of Simulium, 22.

sanguinaria (Stygeromyia), 137.

secedens (Tabanus), 96.

SENEGal, list of species, 197.

septempunctatus ('Tabanus), 73.

Sergent, Drs. Edmond and Étiknne, researches on Tabanidæe and trypanosomiases, 41, 70, 71, 105 (and note).

Seroots (Seruts) or Seroot-flies (Tabanidæ), 36.

sexfasciata (Pangonia), 59.

sharpei (Tabanus), 72.

Sierra Leone and Sierra Leone Protectorate, list of species, 182.

silacea (Chrysops), 48.

Silvius, 42.

similis (Hæmatopota), 126.

Simuliidæ, 22.

Simulium, appearance and external characters, 22 ; distribution and number of recognised species, 22 ; habits, swarms, 23, 24; lifehistory, 24.

and disease, 25.

losses among stock caused by, in parts of United States of America, 25.

damnosum ; probably occurs throughout Equatorial Africa, 26 ; plague of, on right bank of Victoria Nile, in Busoga, Uganda, 27 ; severity of bite of, 27 ; near Ripon Falls, Uganda, a far worse plague 
than mosquitoes and detrimental to cattle, 28; life-history and habits (H. H. King's observations); larva; pupa, 29.

Simulium griseicollis; locally known as Nimitti (Nimetta or Nemetti) in Dongola Province, Anglo-Egyptian Sudan, 31 ; most troublesome at sunset and sunrise, 34 ; occurrence on River Nile, in AngloEgyptian Sudan outside Dongola Province, 35 ; life-history and habits (H. H. King's observations), 32.

latipes, a European species that occurs in South Africa, 25.

—_ wellmanni, in Angola, 30.

Sleeping sickness and Tabanidæ and other biting flies (excluding Glossina palpalis), 40 (note).

- not transmitted by Stomoxys under ordinary circumstances, 153.

socialis (Tabanus), 100.

Somaliland, list of species, 210.

Soumaya or souma, a trypanosomiasis of horses and humped cattle at Ségou (French Sudan), said to be propagated by 'Tabanus ditæniatus and T. biguttatus, 72 .

stigmaticalis (Chrysops), 45.

Stomoxys; number of Ethiopian species, 141 ; life-history, 142. and disease, 142.

bouffardi, 150 (note).

calcitrans, 142 ; probably occurs throughout Africa ; exists throughout the greater part of the world; localities of specimens, 143 ; mode of sucking blood (Newstead's observations), 145 ; Linnæus's observations, 145 (note); anatomy of mouth-parts and internal anatomy; life-history, 146.

thrax, filariasis, 148; surra and other trypanosomiases, 149.

the intermediate host and transmitter of Filaria labiatopapillosa of the ox, 148 .

- and $S$. nigra and disease; summary, 153.

- and S. nigra by far the most widely distributed species of Stomoxys in Africa, 142, 143.

glauca (= S. nigra), 153.

inornata, 159.

lafonti (= S. nigra), 154 (note). nigra, 153 ; except S. calcitrans, the most widely distributed representative of its genus in Africa, 153 ; S. nigra in Ashanti (observations by Dr. W. M. Graham), 155.
Stomoxys nigra as a disease-carrier, 156. - believed to disseminate surra in Mauritius, 154, 157 (and note) ; said to cause disease among camels in East Africa Protectorate (Dr. J. W. Gregory), and among donkeys, mules, horses, and camels in the Bahr-el-Ghazal (observations by the late Major T. E. N. Lewis, A.V.D.), 156.

_- omega, 157; secondary sexual characters in male; differences between female and that of $S$. inornata, 158.

- sp. capable of transmitting Try panosoma cazalboui, the parasite of souma, in French Sudan, 149.

strigipennis (Hippocentrum), 134.

Stygeromyia, characters of genus, 136 .

- maculosa, 136.

- sanguinaria, 137.

suavis (Pangonia (Diatomineura)), 65.

subangustus (Tabanus), 112.

Subpangonia, 42, 55.

subvittatus (Tabanus), 73.

Surra and Phlebotomus (in India), 18.

Swayne, Col. H. G. C., R.E., observations on Tabanidæ in Somaliland, 63.

Sycorax silacea, a Palæarctic bloodsucking species of Psychodidæ (Phlebotominæ); occurrence of another (undescribed) blood-sucking species of same genus in Algeria, 9 (note).

\section{T}

Tabanidæ, external characters, 36-38; number of described, and of known Ethiopian species, 36; bloodthirstiness of females, 38 .

enemies of, 39.

life-history, 39.

and disease, 40 .

and other biting flies (excluding Glossina palpalis) and sleeping sickness, 40 (note).

_ frequently asserted by natives to be responsible for diseases of animals, 41.

Tabaninæ, 66.

Tabanus, number of described African species, 67; plastic characters used in distinguishing species, 67 ; colour and markings of eyes in the living insects; wide distribution of certain species; called Mangrove-flies in West Africa, 68; rare in Cape Colony, 61; lifehistory, 69.

and disease, 70 . æneus, 110. 
Tabanus africanus, 73,81 ; believed by natives on parts of White Nile to cause camel-disease, 83 ; ' in Lorenzo Marques (observations by Mr. F. D. McMillan), 83. agrestis, 120 .

agricola, 120. albilinea, 112. argenteus, 72, 114:

- biguttatus, 69,85 ; sexual dimorphism, 85 ; unusual abundance of males, 86 ; habits in Lorenzo Marques and Anglo-Egyptian Sudan, 88 ; life-history, 89.

billingtoni, 96 .

_- bipartitus (= T. fraternus), 101.

- bipunetatus (= T. ditæniatus), 120.

- blanchardi, (= T. secedens), 96 . (note).

- brucei, 73, 81 .

- brumpti, 93.

- brunnescens (= T. secedens), 96 (note).

- canus, 110.

capensis, 117.

claritibialis, 120

congoiensis, 99.

conspicuous, 107.

denshamii, 108.

disjunctus (possibly a form of

T. ustus), 109.

distinctus, 111.

ditæniatus, extraordinarily wide distribution of, 118; T. ditæniatus in Lorenzo Marques (observations by Mr. F. D. McMillan), 120.

diversus, 72, 112 ; differences

from $T$. insignis, 113.

dorsivitta (= T. tæniola), 103.

fasciatus, $69,73,78$.

fraternus (syn. T. bipartitus and

T. trisignatus), 101.

fuscipes, 120.

gabonensis (= T. secedens), 69 .

gratus, 114.

insignis, 72.

kingsleyi, 98.

latipes, 73, 84 .

laverani, 115.

lemairei, 99.

liventipes, 107.

macrops (= T. tæniola), 103.

maculatissimus, 91 . irroratus, 91 .

marmoratus, 95.

morsitans, 117.

multipunctatus (=T. canus), 110.

nigrohirtus (= T. socialis), 69 , 101.

nigrostriatus, 107.

nyasæ, 109.
Tabanus obscurefumatus, 94 .

—_ obscurissimus, 69,73 .

par, 76.

pluto, 91.

quadriguttatus, 94.

quadrisignatus, 111 .

rothschildi, 116 ; differences from

T. morsitans, 117.

rubicundus (=T. variatus), 105.

ruficrus, 92.

ruwenzorii, $117,118$.

secedens, 96 ; in Ashanti (obser-

vations by Dr. W. M. Graham),

and in French Congo (observations

by M. Roubaud), 98 .

septempunctatus, 73 .

serratus (=T. variatus), 105.

sharpei, 72, 113.

socialis, 100 ; possibly identical

with T. testaceiven tris, 101.

socius (= T. tæniola), 103.

stigma, Walk., nec Fabr. $(=\mathrm{T}$.

tenuicornis), 117.

subangustus, 112.

subvittatus, 73 .

tæniatus, 117.

tæniola (most widely distributed of African Tabanidæ), 69, 102 ; variation in abdominal marking, 102 ; said to kill camels in French Congo and Upper Egypt, 72, 104.

tarsalis (= T. nyasa), 110.

temperatus (= T. ustus), 108.

tenuicornis, 117.

testaceiventris (probably $=\mathrm{T}$. secedens or T. socialis), 69.

thoracinus, 69,74 .

trisignatus (= T. fraternus), 101. ustus, 108.

variabilis, 116.

variatus, 105; perhaps $=\mathrm{T}$. sagittarius, 106.

virgatus (= T. tæniola), 103.

wellmanii, $72,113$.

taciturna (Hæmatopota), 124.

tæniatus (Tabanus), 117.

tæniola (Tabanus), 69, 102.

tenuicornis (Tabanus), 117.

Ter Abbiot, native name for Tabanus ditæniatus near Lake Chad, 119.

_- Azarak, native name for Tabanus tæniola near Lake Chad, 103.

Ter-el-gufar, native name for Tabanus africanus on parts of White Nile, 83.

testaceiventris (Tabanus), 69.

Thaumastocera, 66 . akwa, 66.

Therioplectes (subgenus of Tabanus), 117.

Third longitudinal vein (in wings of Tabanidæ), 121 (note).

thirouxi (Lyperosia), 140. 
thoracinus (Tabanus), 69, 74 .

Thriambeutes, 42.

Togoland, list of species, 201.

torquens (Hæmatopota), 131.

Touna (native name of Chrysops dimidiata in French Congo), 48.

Tracheal (or rectal) gills of Simulium larvæ, 26 (note).

Transvaal, list of species, 191.

trimaculatum (Hippocentrum), 134, 135.

Trypanosoma brucei (the parasite of nagana) can be conveyed mechanically by either Stomoxys nigra or S. calcitrans, or perhaps by both (observations by G. Martin, Lebœuf, and Roubaud in French Congo), 150.

- cazalboui (the parasite of souma, a disease causing great mortality among cattle, horses, and donkeys in French Sudan) and Stomoxys sp. (investigations by Dr. G. Bouffard), 149.

gambiense (the parasite of sleeping sickness) and Stomoxys; no experiments on direct transmission yet made; fate of the parasites when ingested by these flies, 151.

- theileri (cause of gall- or bilesickness among cattle in Transvaal), transmitted by Hippobosca rufipes and $H$. maculata, $151,176$.

Trypanosomiasis in North-Western Rhodesia, and Stomoxys and Lyperosia (statements by Montgomery and Kinghorn), 152.
$\mathbf{U}$

Uganda Protectorate, list of species, 187.

ugandæ (Hæmatopota), 132.

unicolor (Hæmatopota), 126. ustus (Tabanus), 108.

\section{V}

variabilis (Tabanus), 116.

variatus (Tabanus), 105.

versicolor (Hippocentrum), 134.

vittata (Hæmatopota), 122 (note).

\section{W}

Wayam Fly, native name for species of Tabanus (including T. latipes and T. tæniola), near Pawa, Katsina-Sokoto Boundary, Northern Nigeria, 85.

wellmanii (Tabanus), 113. (Simulium), 30.

Wings, resting position of, in Tabanidæ, 38.

$$
\mathbf{Y}
$$

Yembe (native name of Chrysops dimidiata in French Congo), 48.

\section{$\mathbf{Z}$}

Zanzibar Protectorate, list of species, 187.

zonata (Pangonia), 59. 

n. 

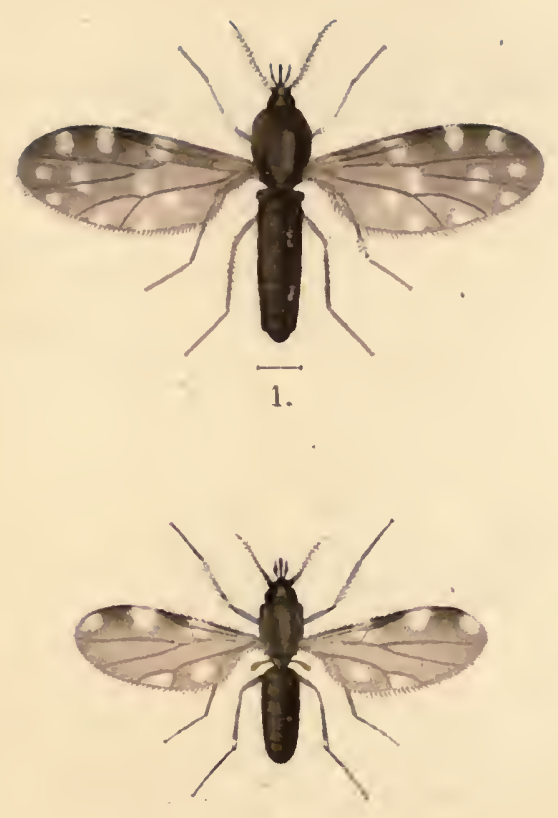

3.

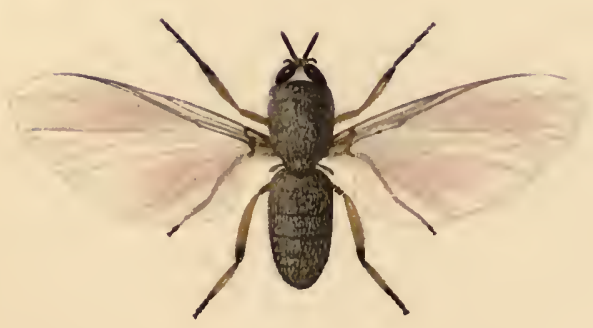

5.

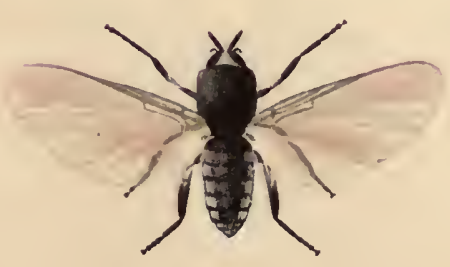

7.

1. Culicoldes Milsei, Austen.

3. Culicoides grahami, Austen.

5. Simulium latipes, $M g$.

7. Simulium wellmans, Roubaud.

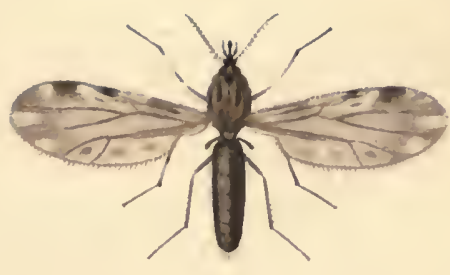

2.
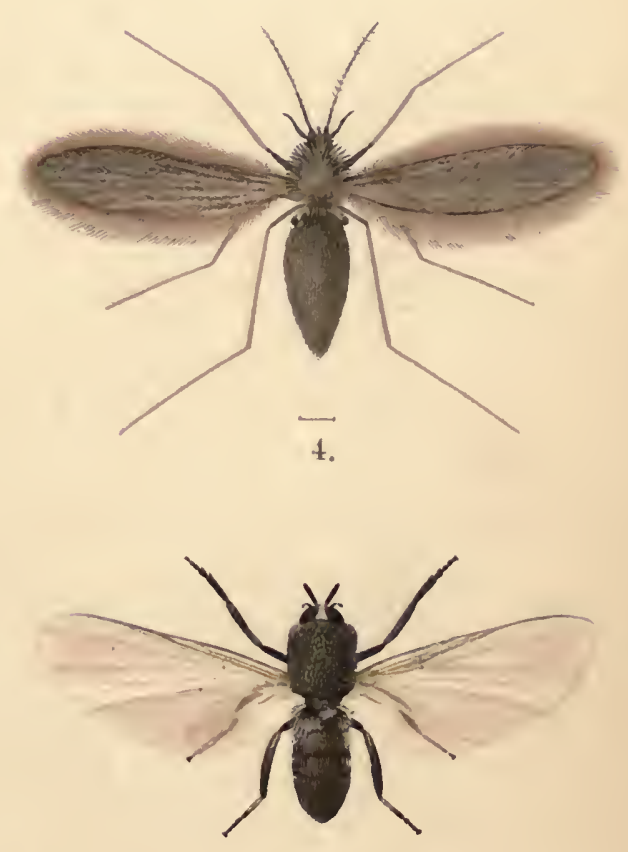

6.

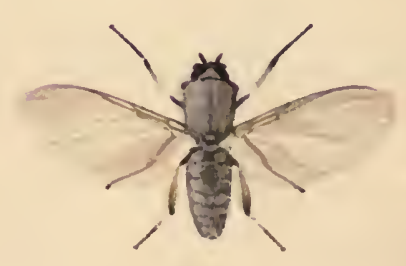

8.

2. Culicoides brucei, Austen.

4. Pulizotomus dunoscqi, Neven-Lemaire.

6. Simulium damosum, Theob.

8. Simulium griseicollis, Becker. 

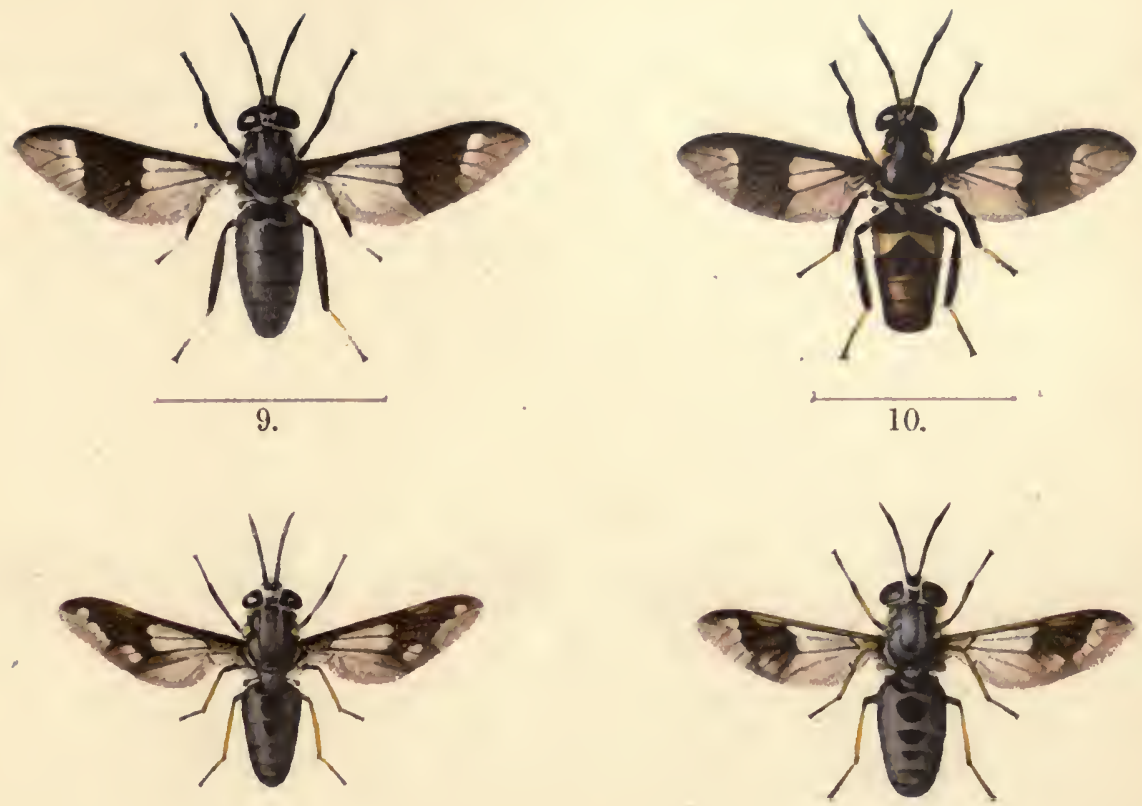

11.

12
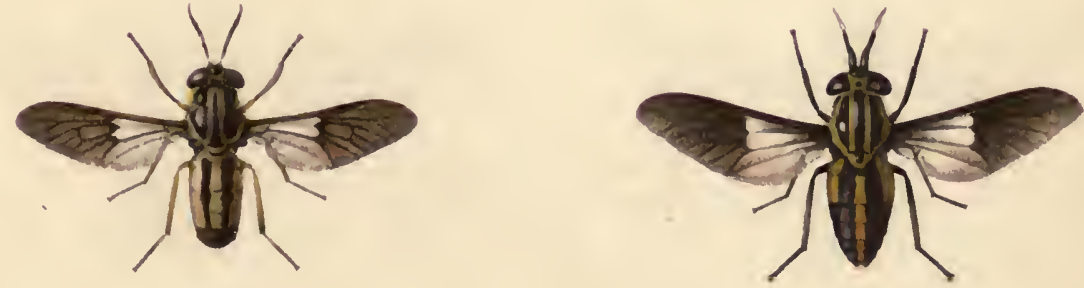

13.

14.

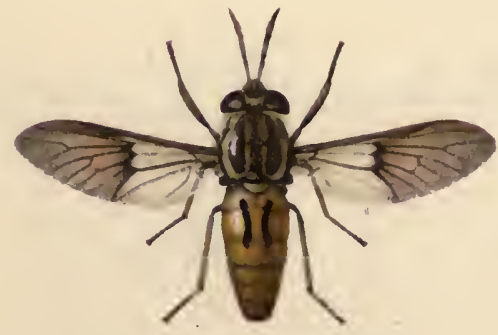

15.

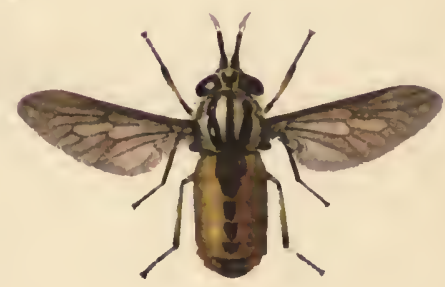

16.

9. Curysops funebris, Austen.

11. Chrisops sticinaticalis, Lie.

13. Chrysops dimidita, v.d. Wulp.

15. Chinyops silacea, Austen.
10. Chrysops loxiticonsis, Macq.

12. Chrysops distinctipennis, Austen.

14. Chirysops nigriflava, Austen.

16. Chrysops Calida, Walk. 


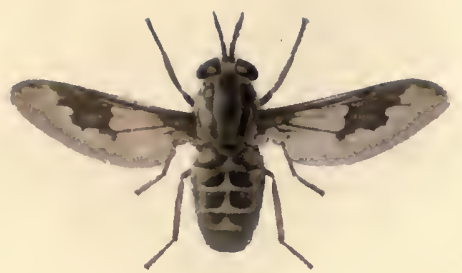

17.
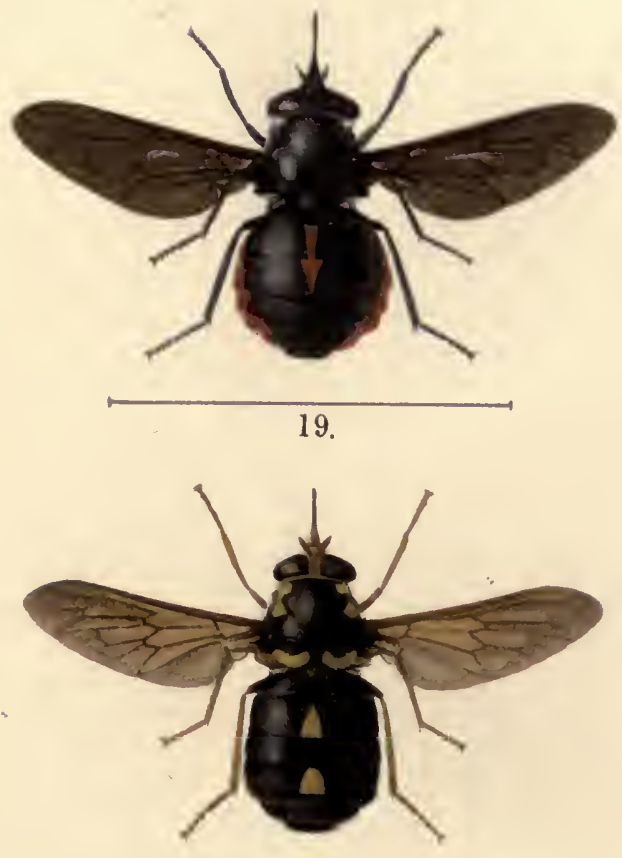

21.

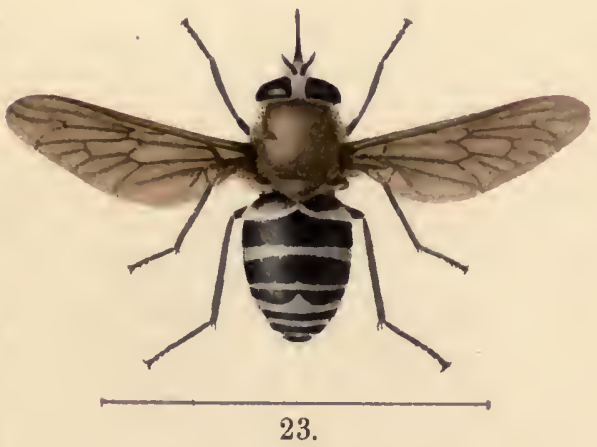

17. Chrysops brucei, Austen.

19. Cadicera rubramarginata, Macq.

21. Cadicera chrysostigma, Wied.

23. Pangonia sexfasciata, Walk.

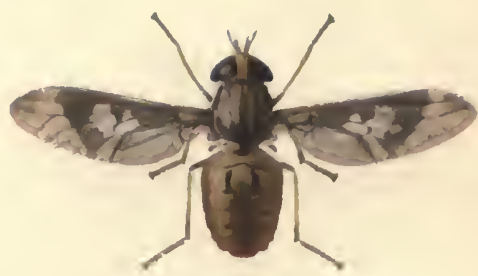

18.
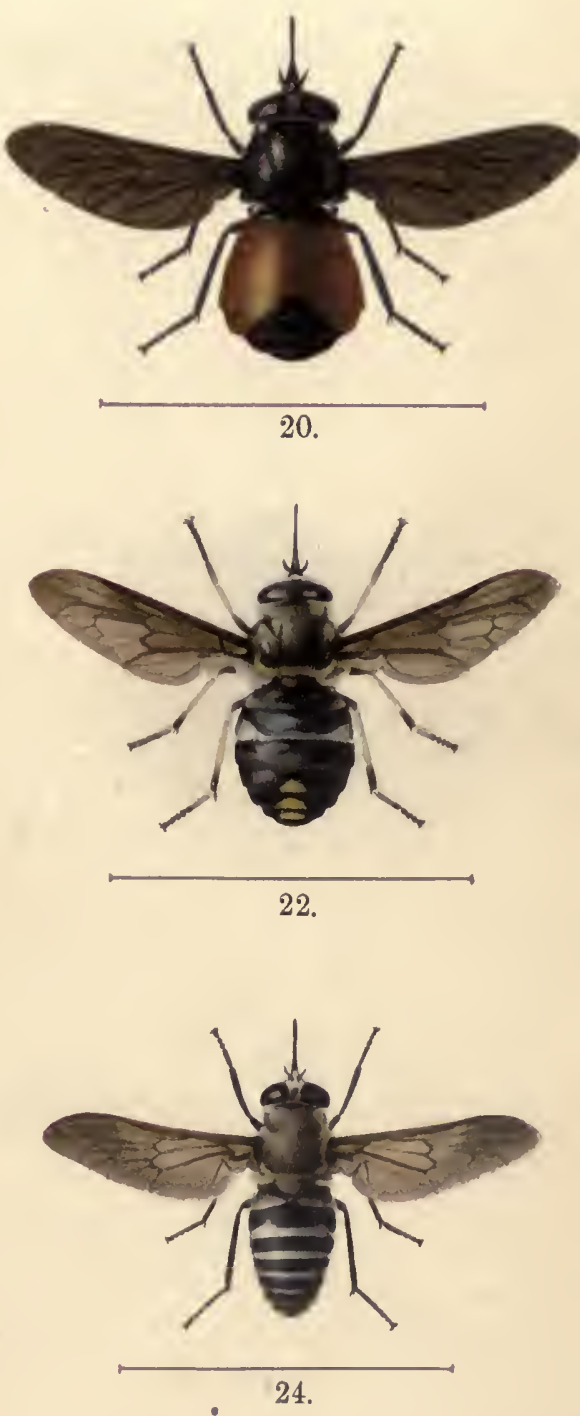

18. Rhinomyza denticornis, Wied.

20. Cadicera melanopyga, Wied.

22. Cadicera quinquemaculata, $A u$

24. Pangonia elongata. Ricardo. 



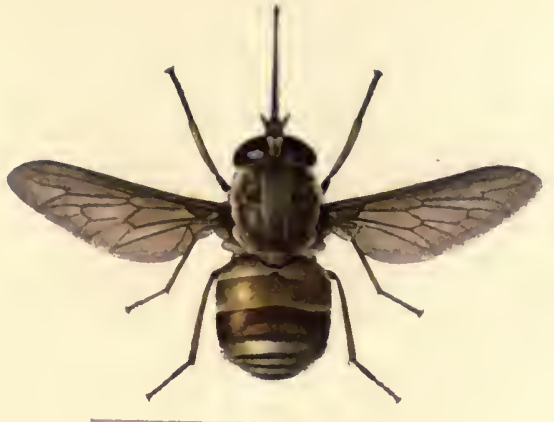

25.

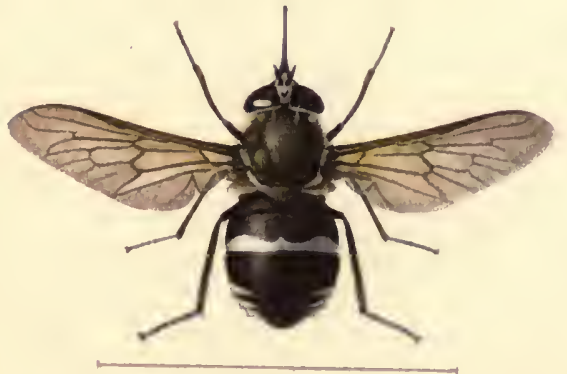

27.

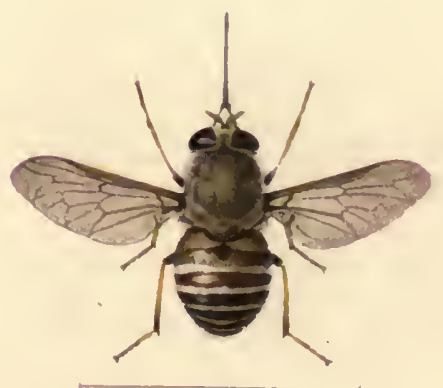

28.

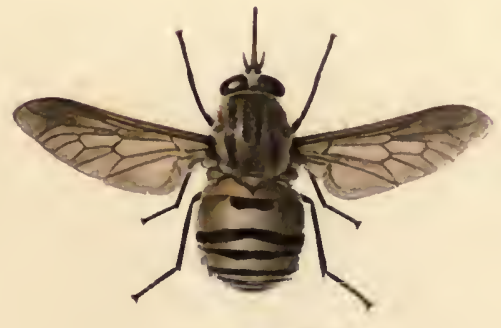

30.

25. Pangonia zonata, Walk.

27. Pangonia angulata, Fabr.

28. Pancionia compacti, Austen.

30. Pangonia suavis, $L w$.

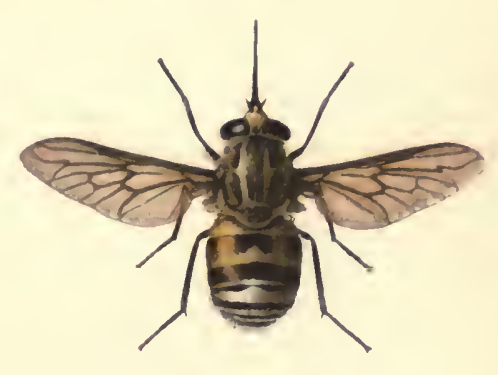

26.

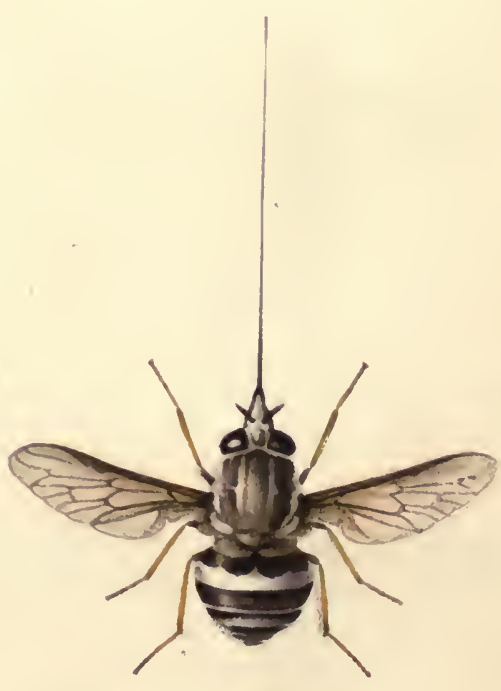

29.

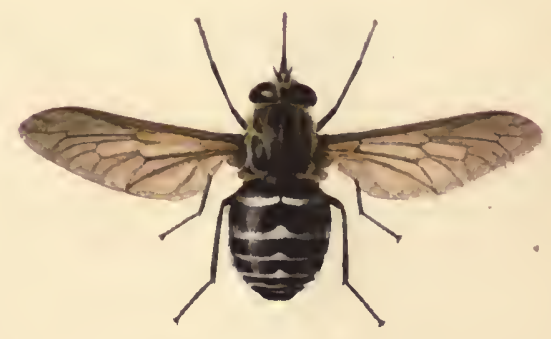

31.

26. Panfionia adjuncta, Walk.

29. Pangonia gulosa, Wied.

31. Pangonia brunnipinnis, Lu. 


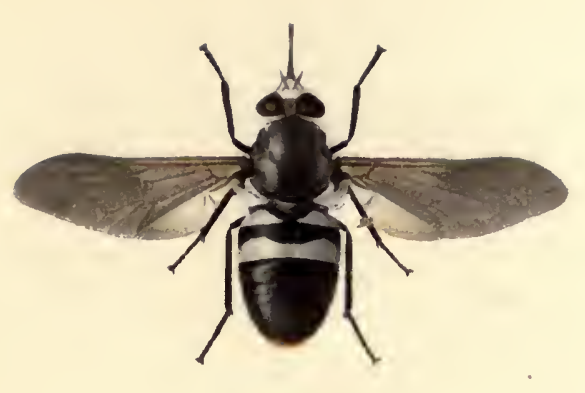

32.

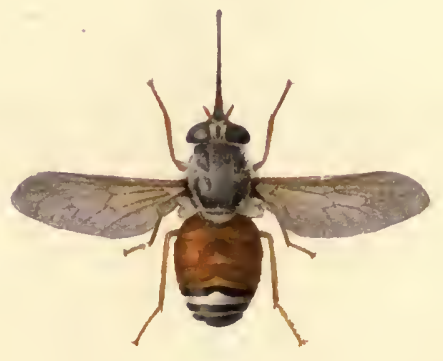

34.

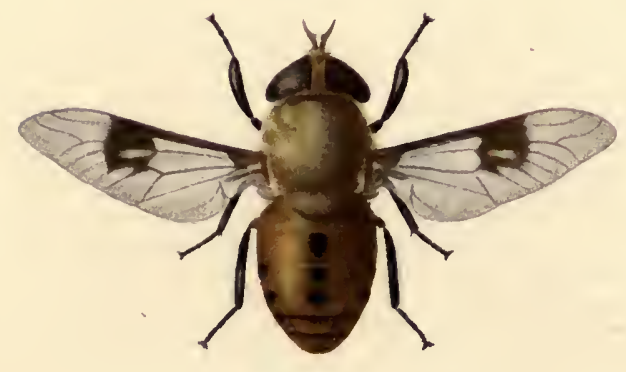

36.

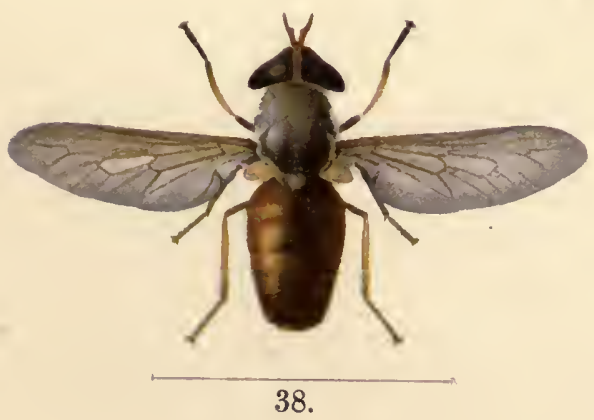

38.

32. Pangonia beckeri, Bezzi.

34. Pangónia rüppellit, Jaenn.

36. Tabanus septempunctatus, Ricardo.

38. Tabanus thoracinus, Pal. de Beauv.

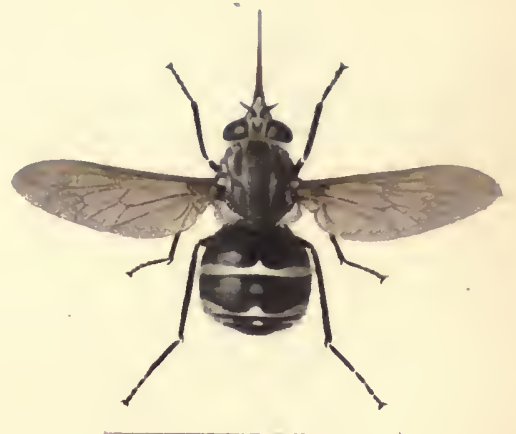

33.

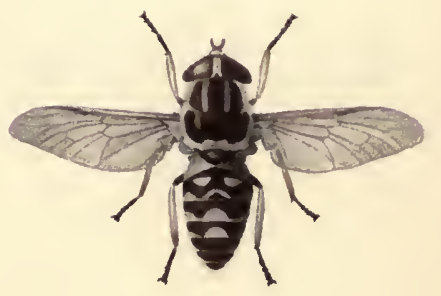

35.

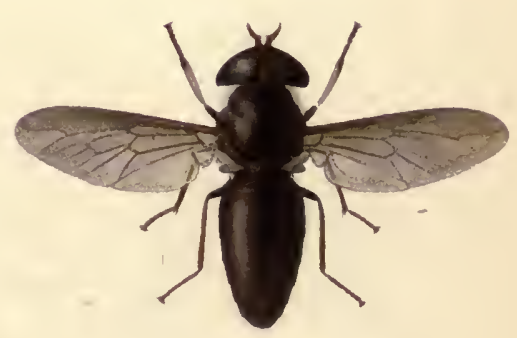

37.

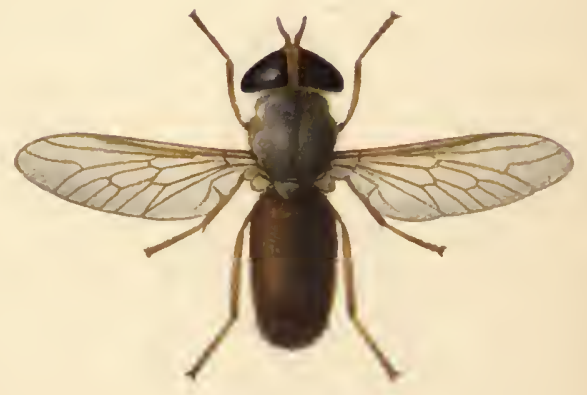

39.

33. Pangonia conjuncta, Walker.

35. Tabanus insignis, Loew.

37. Tabanus obscurissimus, Ricardo.

39. Tabanus Par, Walker. 



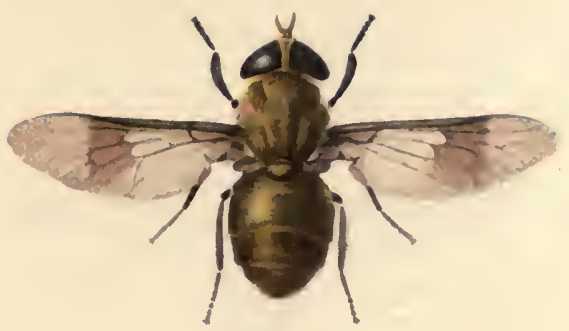

40.

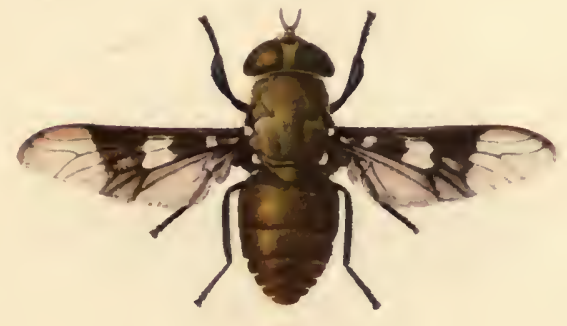

42.

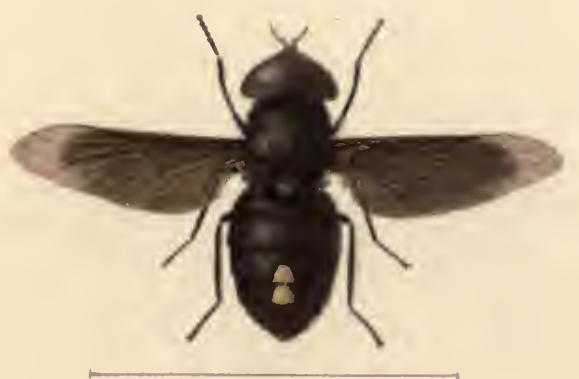

44.

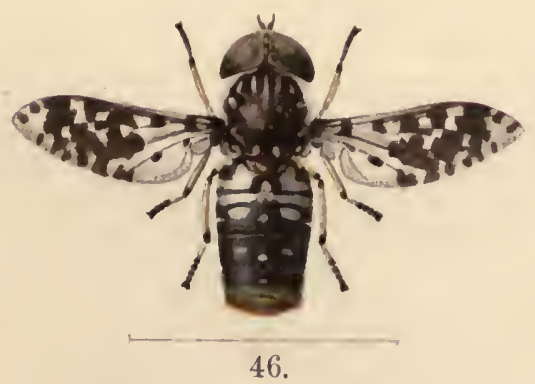

40. Tabanus fasciatus, Fabr.

42. Tabanus africanus, Gray.

44. Tabanus bigutratus, Wied., 8 .

46. Tabanus maculatissimus, Mac\%.

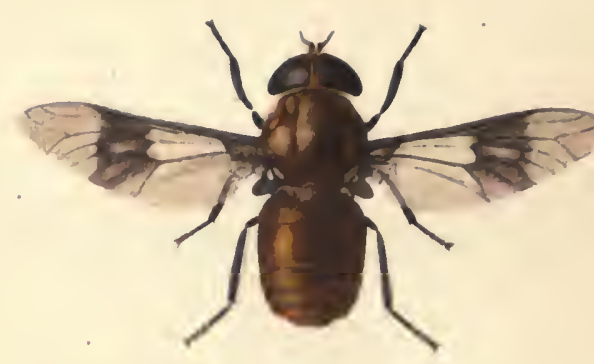

41.

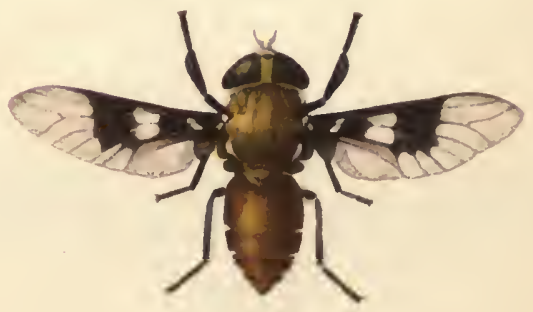

43.
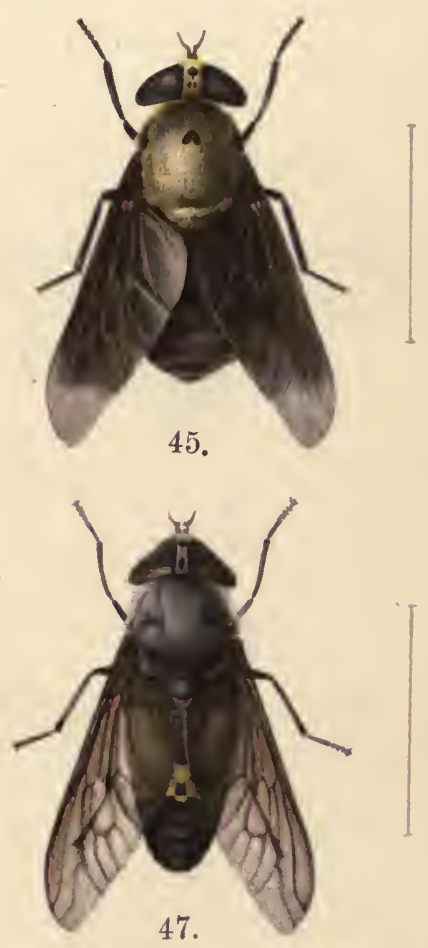

41. Tabanus brucei, Ricardo.

43. Tabanus latipes, Macq.

45. Tabanus biguttatus, Wied.,

47. Tabanus pluto, Walk. 


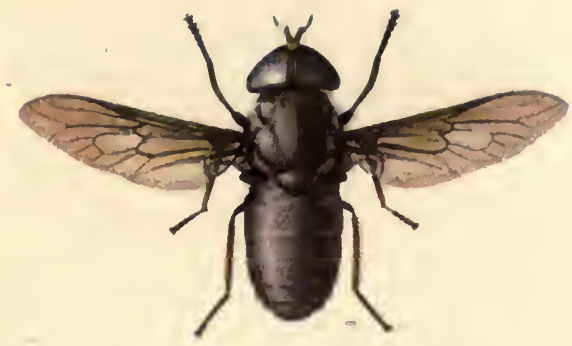

48.

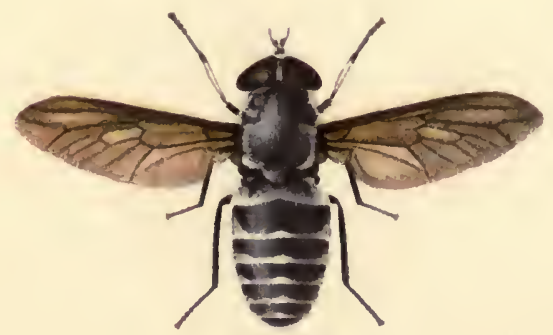

50.

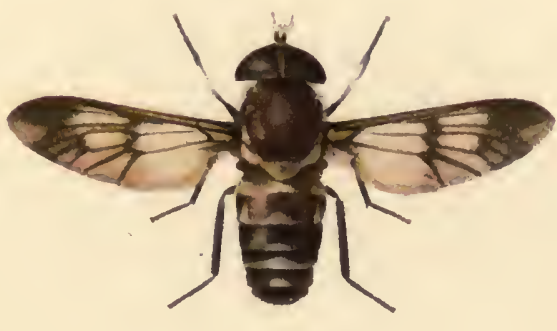

52.

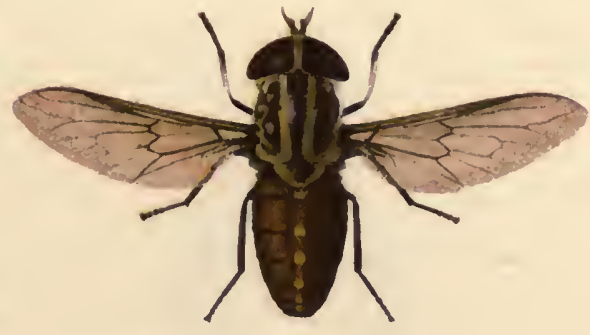

54.

48. Tabanus ruficrus, Pal. de Becuv.

50. Tabanus obscurefumatus, Surconf:

52. Tabanus marmoratus, Surcouf:

54. Tabanus secenens, Walk.

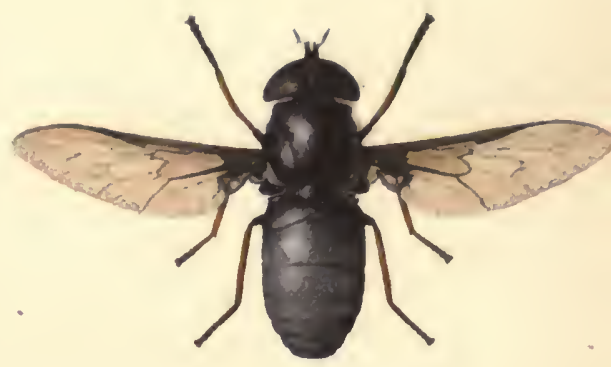

49.

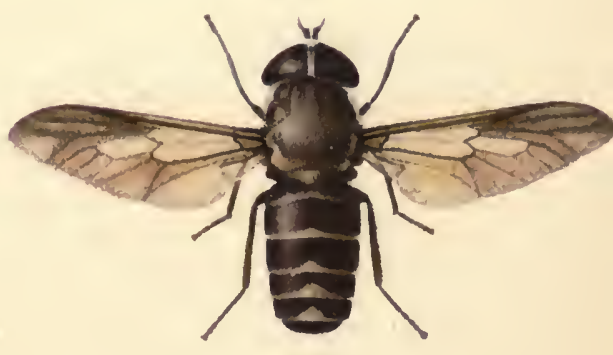

51.

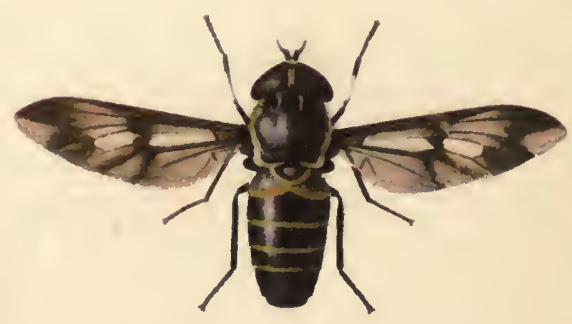

53.

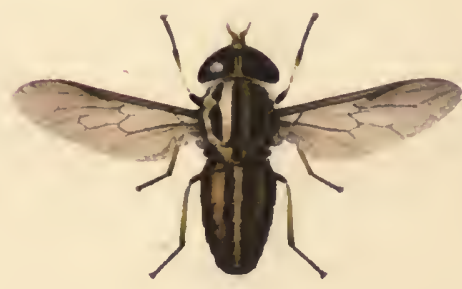

55.

49. Tabanus brumpti, Surcouff.

51. Tabanus quadrigutratus, Rice 53. Tabanus billinatoni, Newstear 55. Tabanus kivgsleyi, Ricardo. 

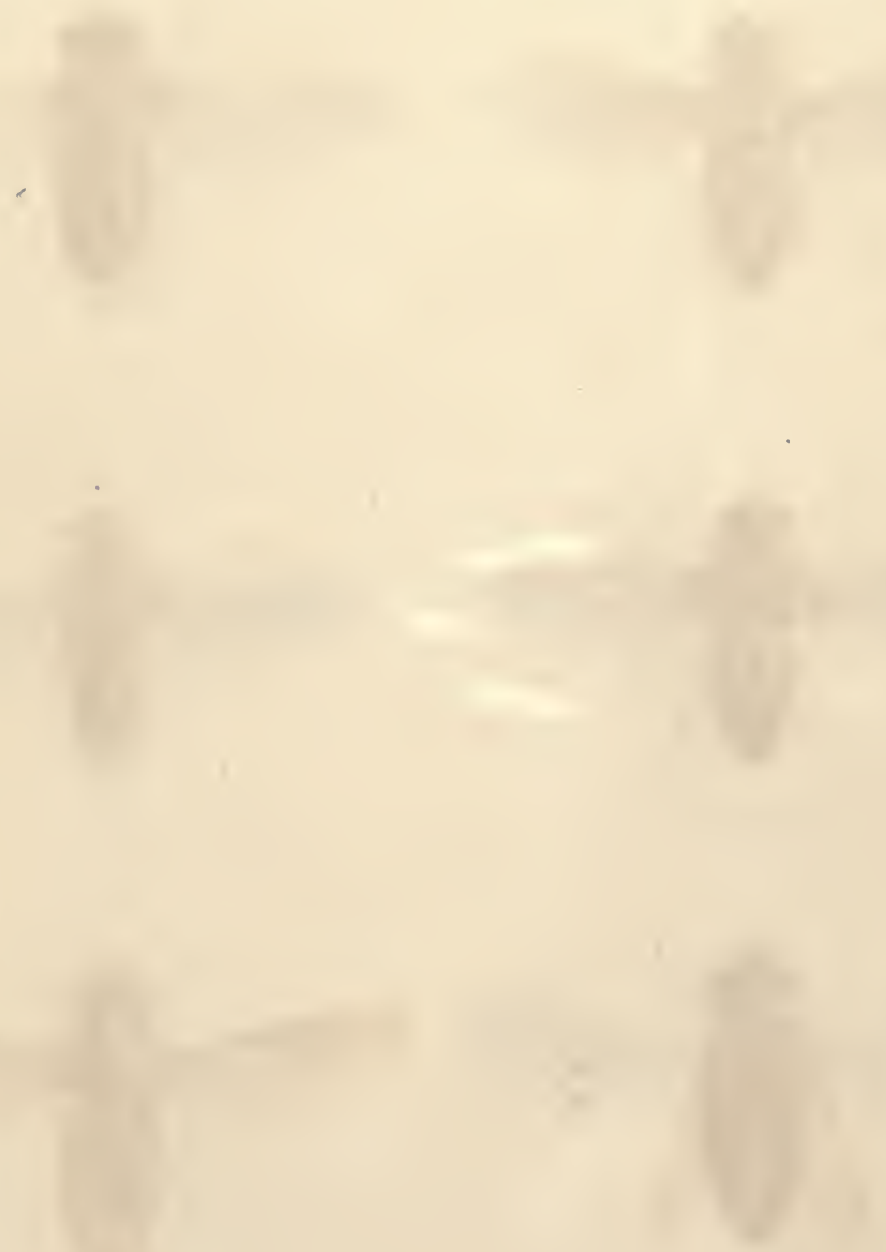


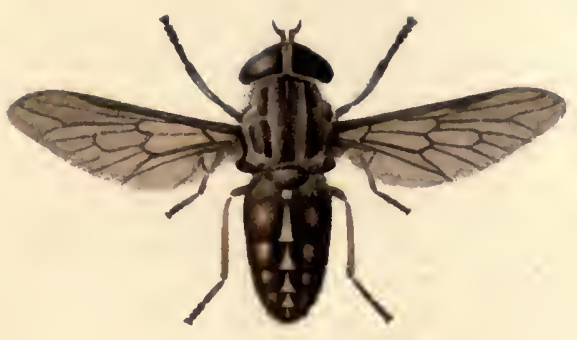

56.

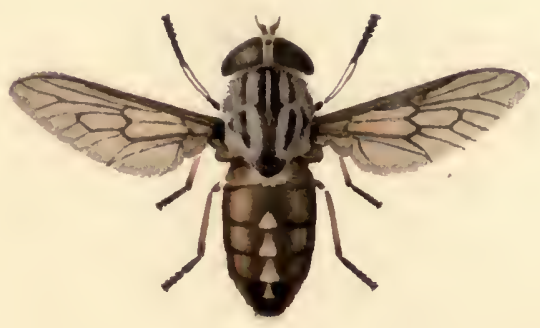

58.

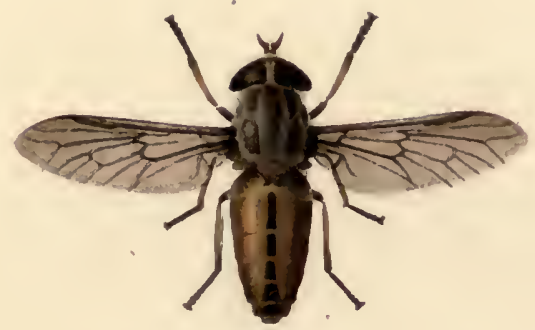

60.

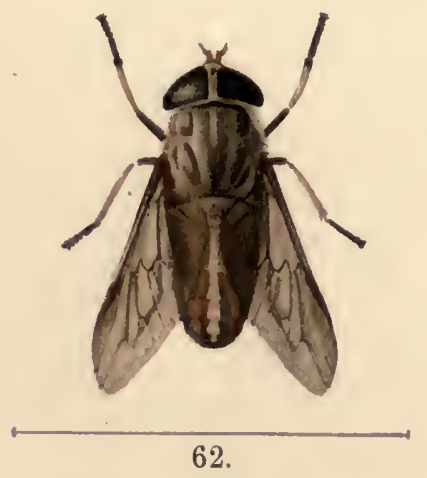

56. Tabanus congolensis, Ricardo.

58. Tabanus fraternus, Macq.

60. Tabanus nighostriatus, Ricardo.

62. Tabanus conspicuus, Ricardo.
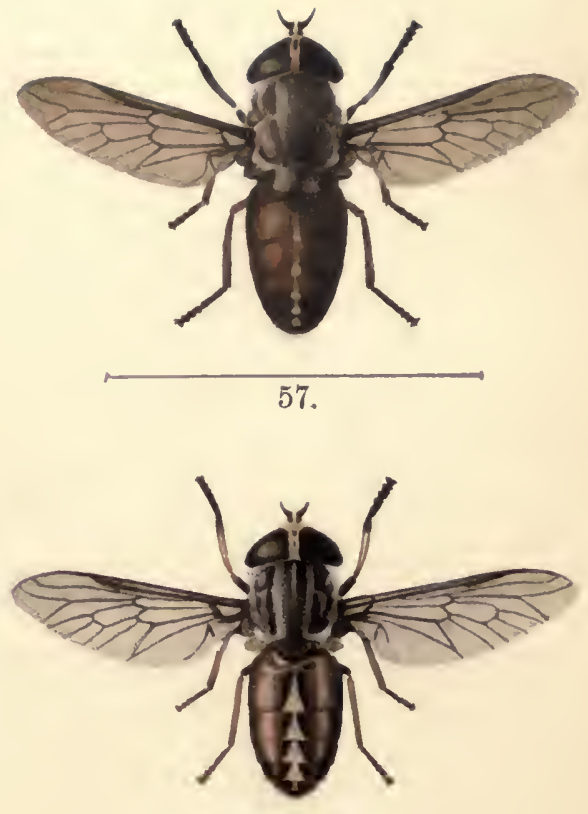

59.

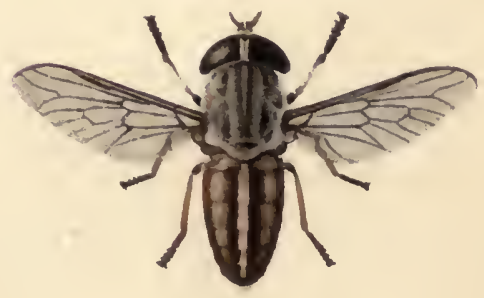

61.

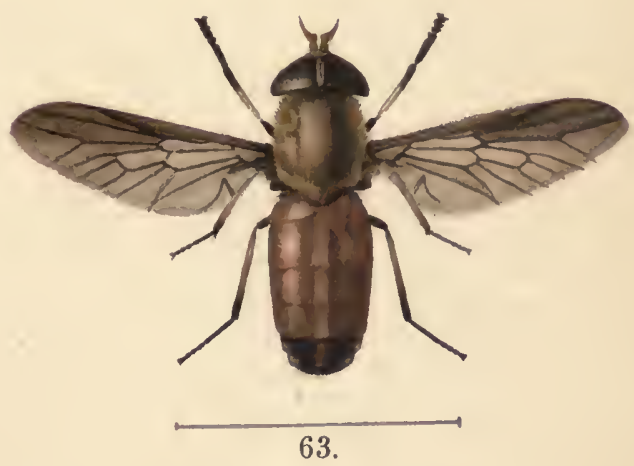

57. Tabanus socjalis, Walk.

59. Tabanus variatus, Walk.

61. Tabanus taeniola, Pal. de Beauv.

63. Tabanus liventipes, Surcouf. 
-
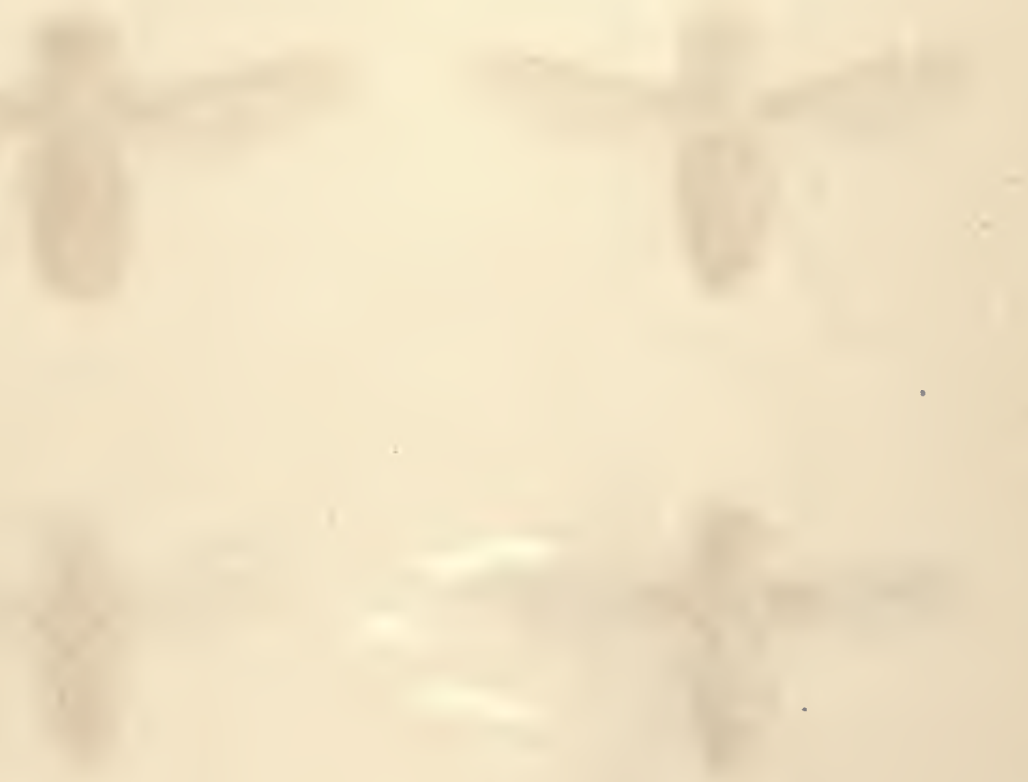


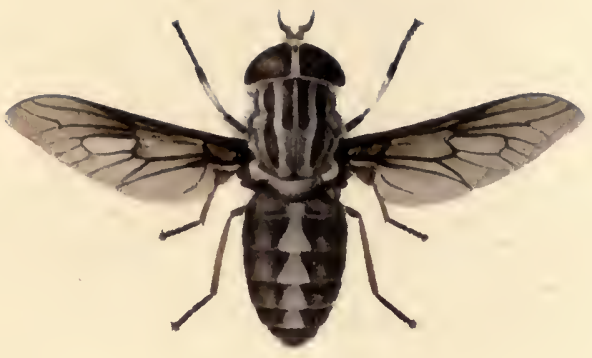

64.

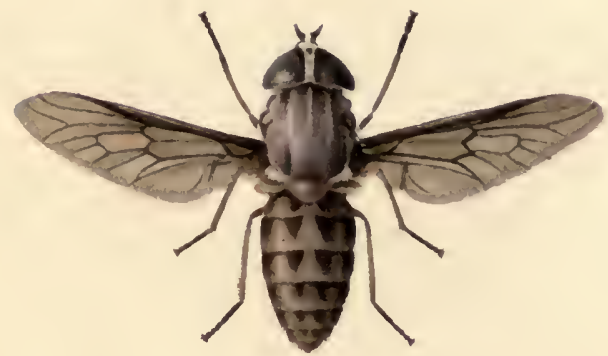

66.

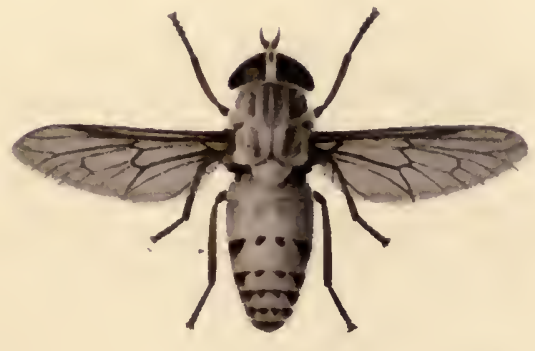

68.

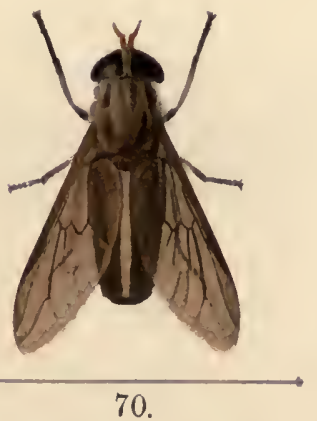

64. Tabanus denshamil, Austen.

66. Tabanus myasae, Ricardo.

68. Tabanus canus, Karsch.

70. Tabanus subangustus, Ricardo.

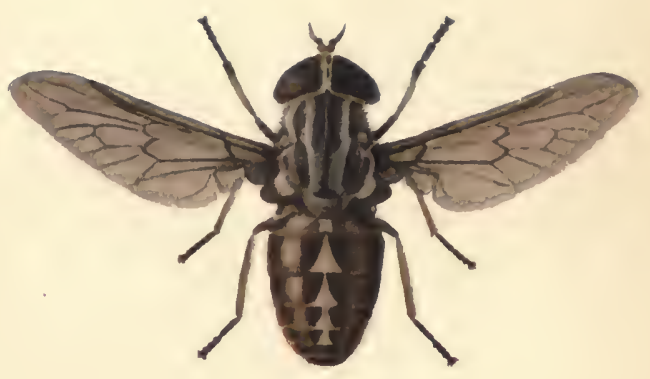

65.

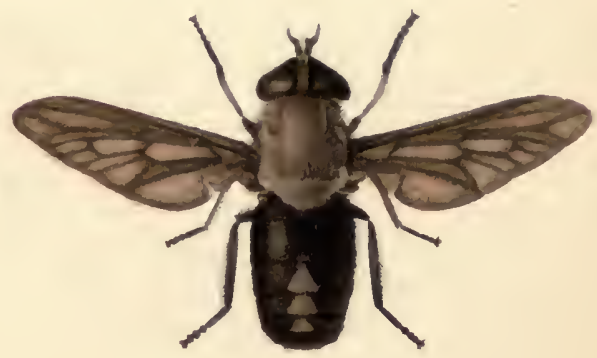

67.

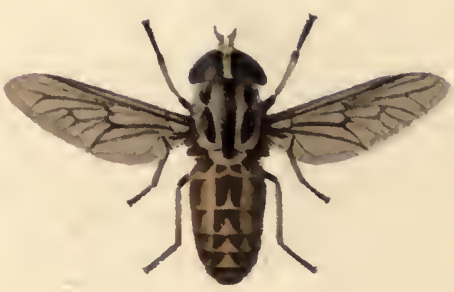

69.

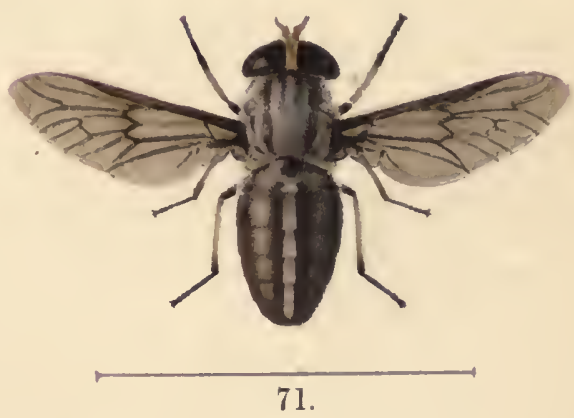

65. Tabanus ustus, Walk.

67. Tabanus aeneus, Surcouf.

69. Tabanus quadrisignatus, Ricardo.

71. 'Tabanus albilinea, Walk. 


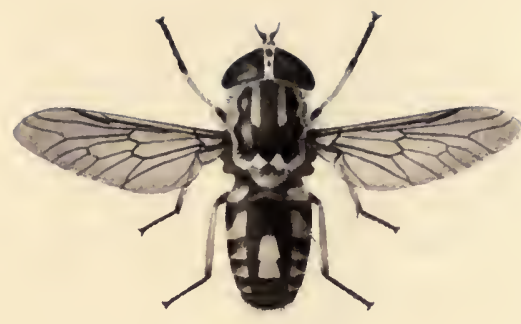

72.

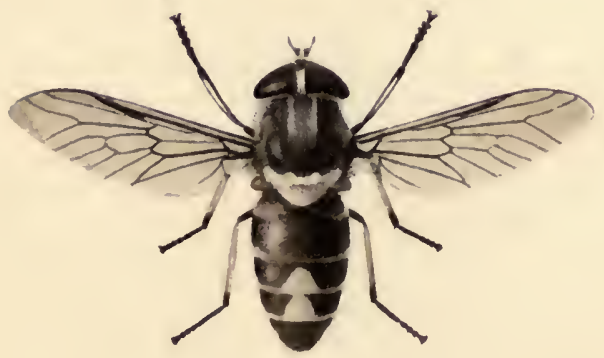

74.

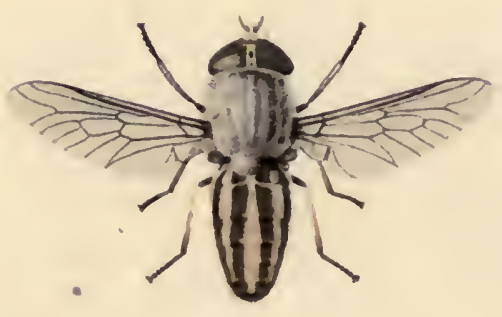

76.

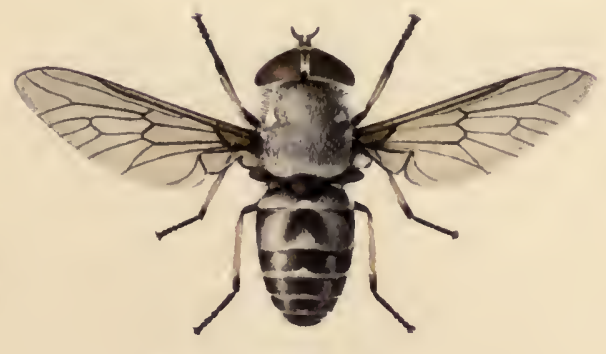

78.

72. Tabanus diversus, Ricardo.

74. Tabanus wellmanil, Austen.

76. Tabanus gratus, $L w$.

78. Tabanus variabilis, Lw.
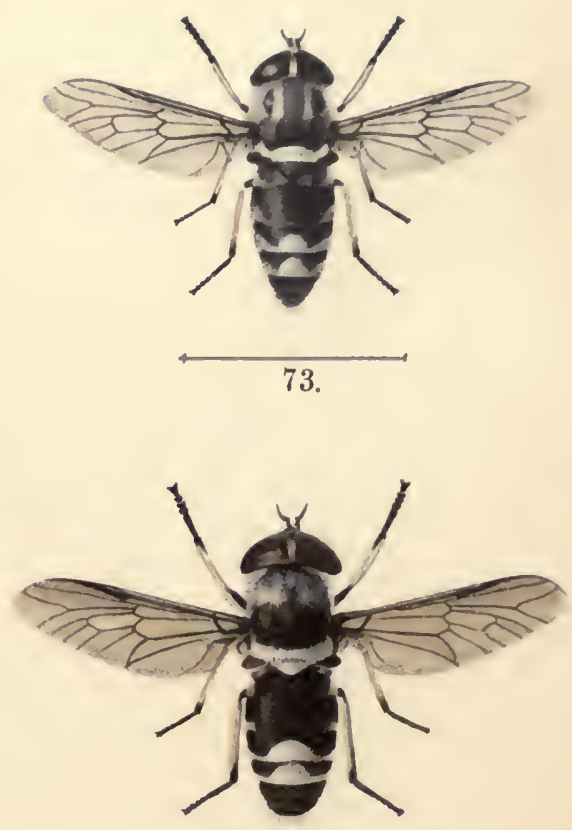

75.

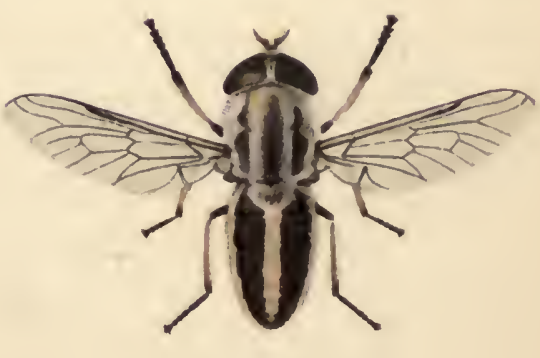

77.

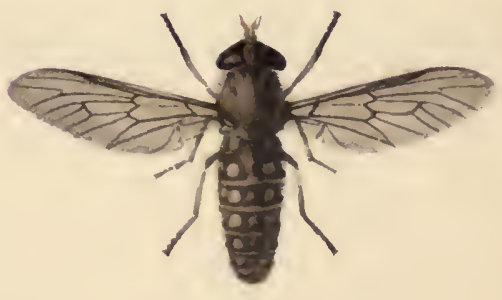

79.

73. Tabanus sharpei, Austen.

75. Tabanus argenteus, Surcouf.

77. Tabanus laverani, Surcouf.

79. Tabanus rothschlldi, Surcouf: 



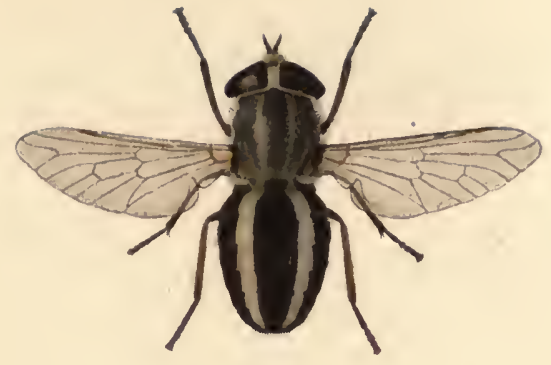

80.

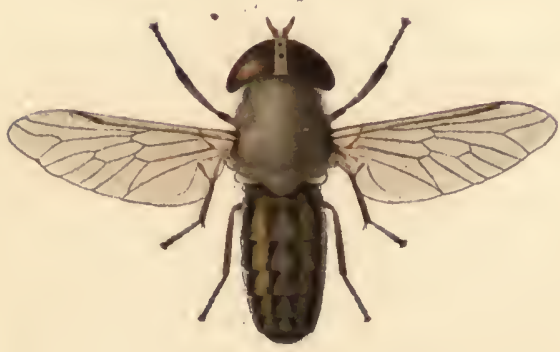

82.

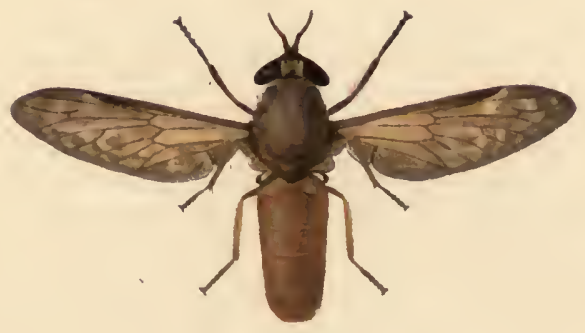

s4.

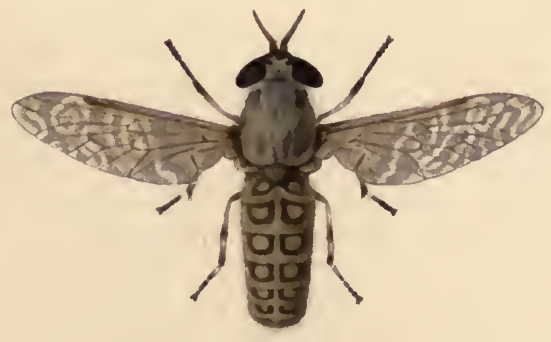

86.

80. Tabanus tamiatus, Macq.

82. Tabanus ditaeniatus, Macq.

84. Haematopota fulva, Austen.

86. Haematopota Pallidipennis, Auster.

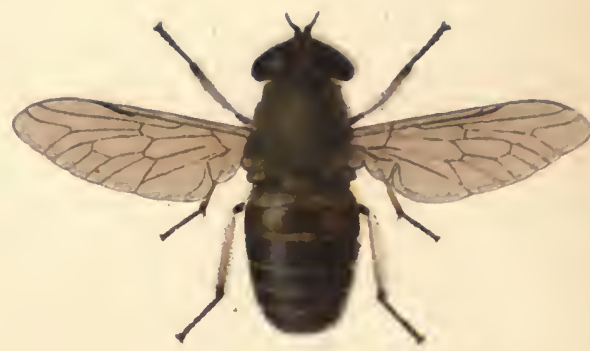

81.

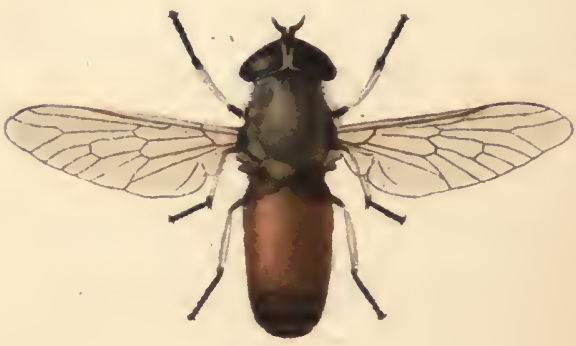

8.9.

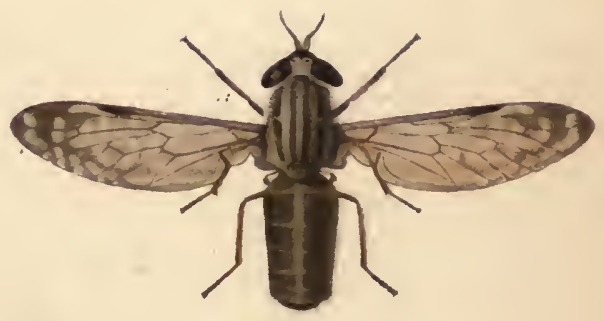

85.

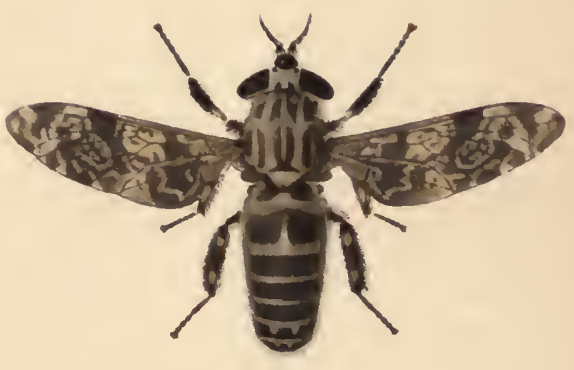

Si.

81. Tabanus ruwenzorit, Ricardo.

83. Tabanus claritibialis, Ricardo.

85. Habmatopota dexsmami, Austen.

87. Hanmatopota bullatifroxs, Austen. 



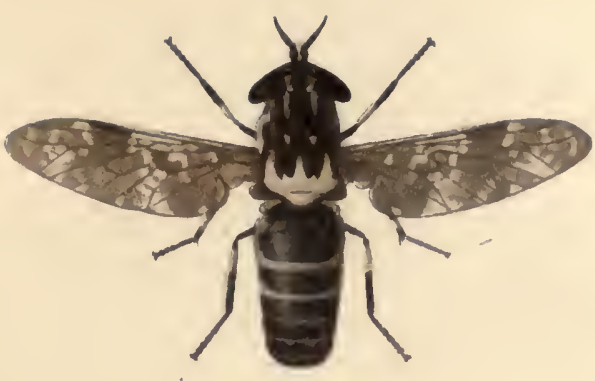

88.

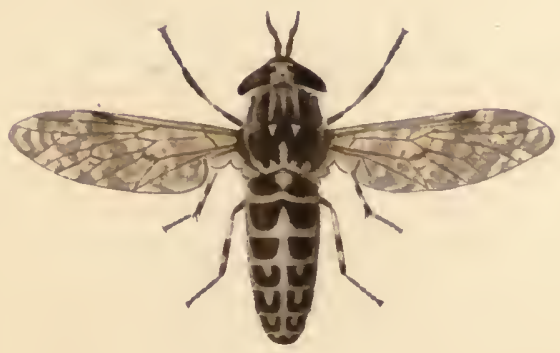

90.

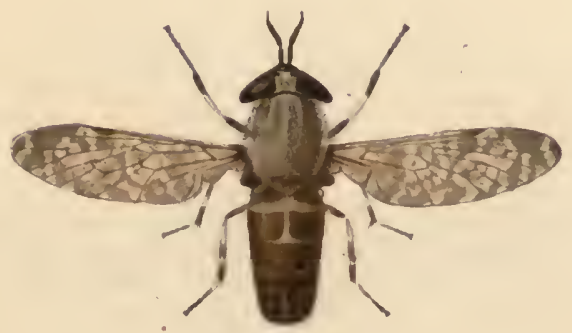

92.

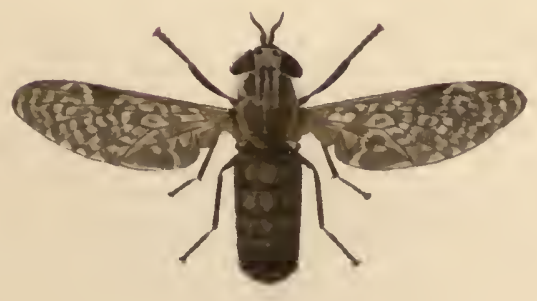

94.

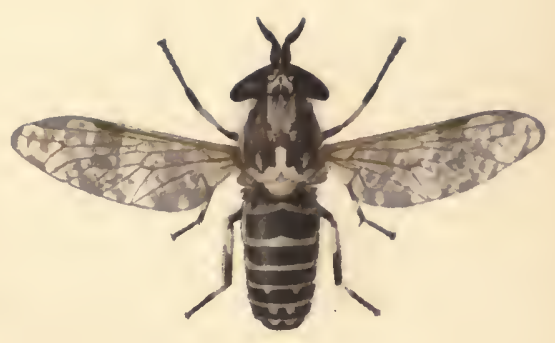

89.

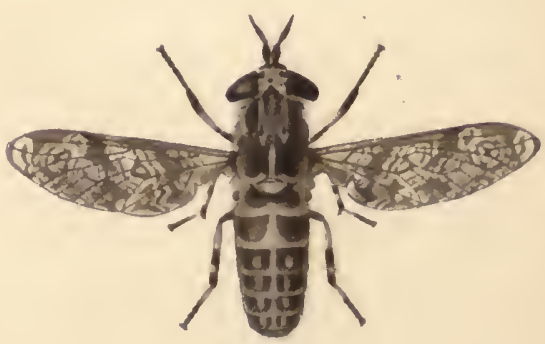

91.

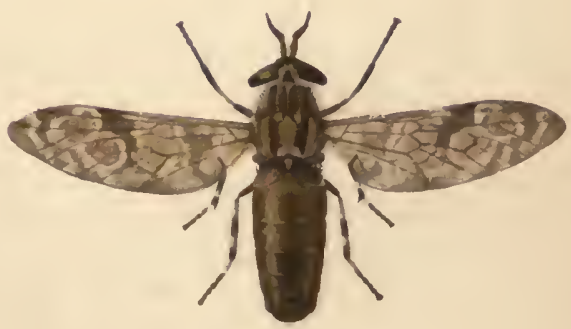

93.

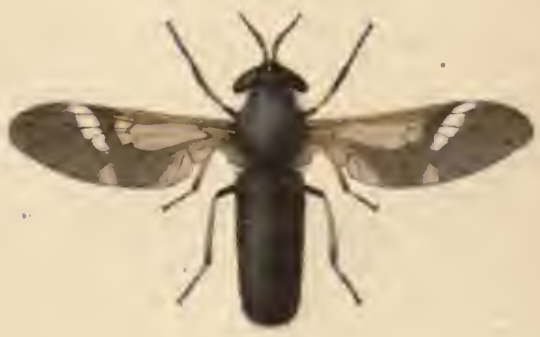

95.
88. Hanmatopota miefer, Auster.

90. Habiatopota Macta vs, Austen.

12. Hanmatopota rorquens, Austen.

94. Hakwatopota lackssiss, Austeu.
89. Hanmatopota DECORA, Walk.

91. Hammapora coronata, Austeu.

93. Haenatopota U(iandae, Ricardo.

95. Hippocentrua versicolor, Austere. 


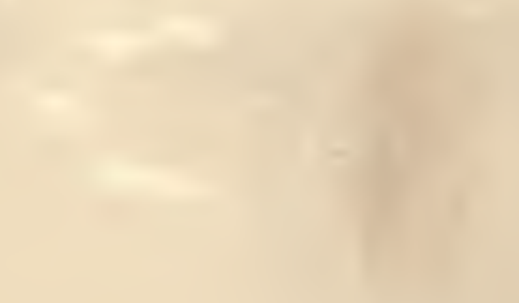




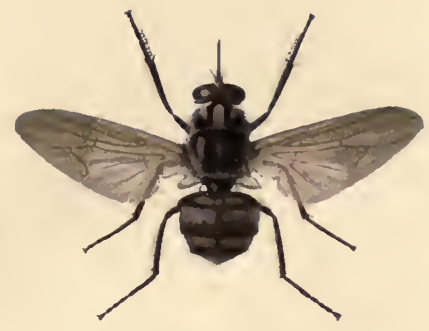

96.

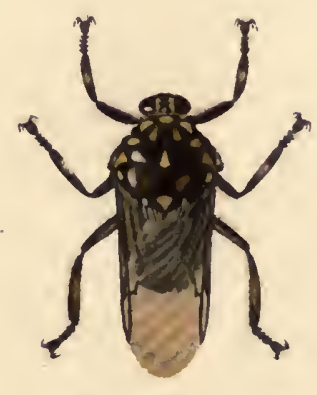

98.

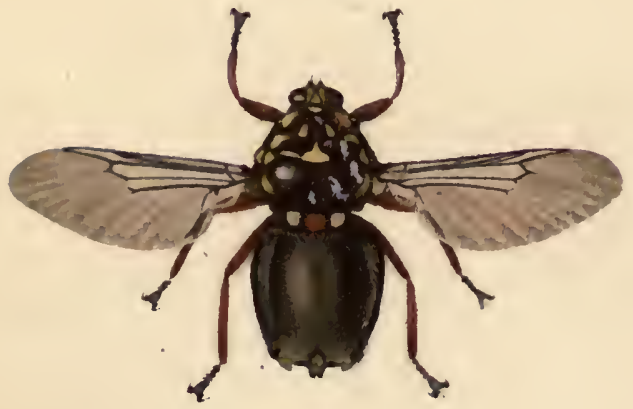

100.

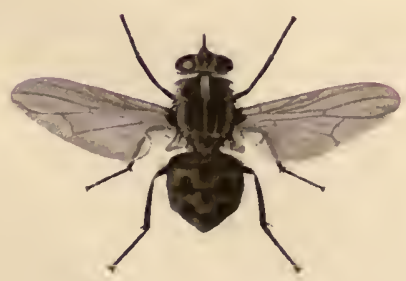

102.

96. Stomoxys onega, Newstead. ठ

98. Hippobosca strunhionis, Janson.

100. Hipponosca RUfipes, von Olfers.

102. Stomoxys calcitrans, Linn.

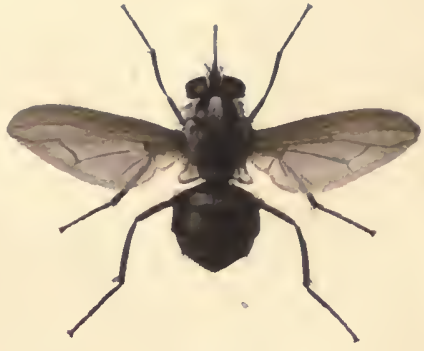

97.

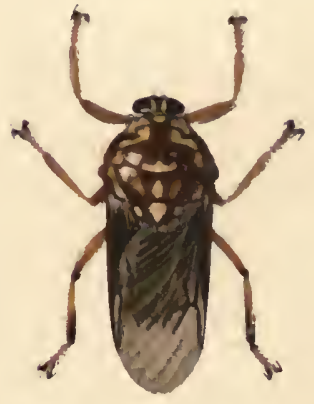

99.

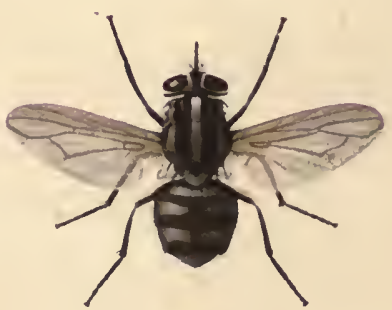

101.

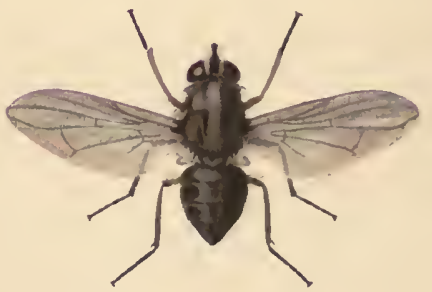

103.

97. S'tomoxys inornate, Grünberg. 99. Hippobosca maculata, Leach. 101. Stowoxys Nigra, Macq.

103. Lyperosia punctigera, Austen. 

$-\infty$ 


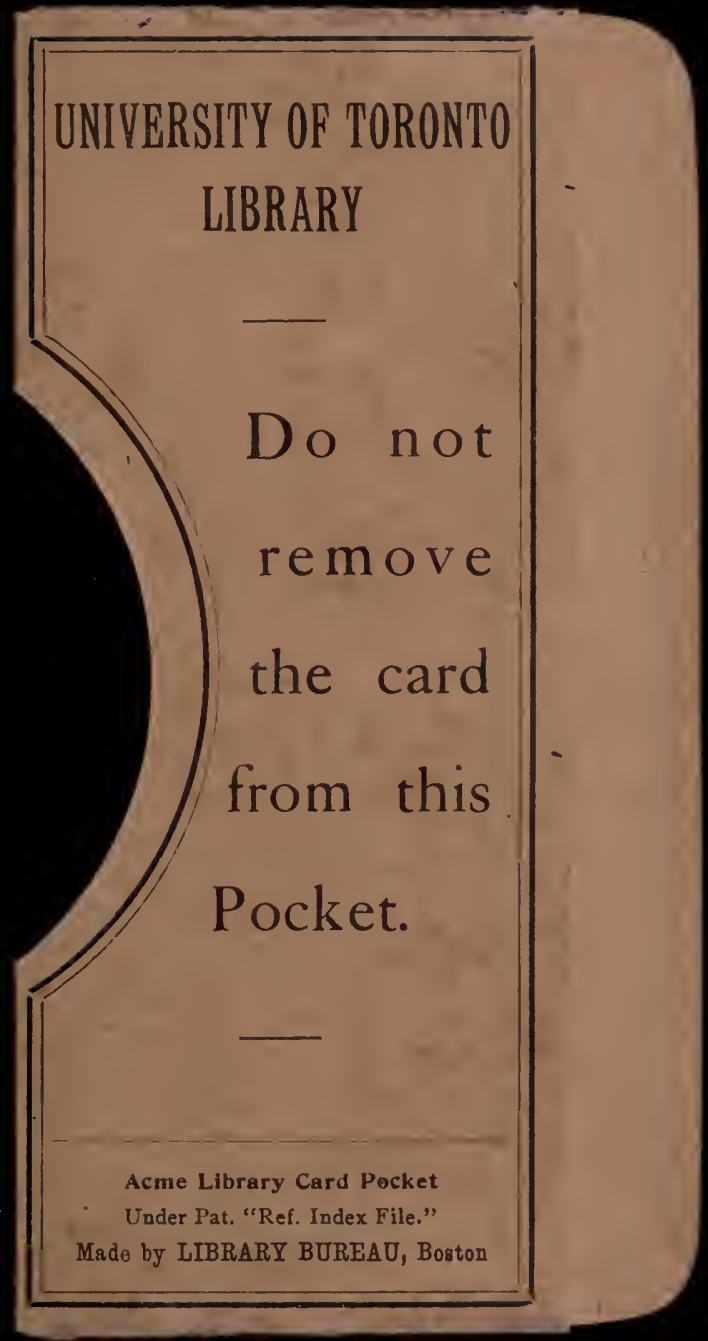


